DOUGLAS RICHTER

UMA ROTA DE RECUPERAÇÃO DE METAL A PARTIR DE ESCÓRIA SECUNDÁRIA DA PRODUÇÃO DE FERRONÍQUEL

São Paulo 
DOUGLAS RICHTER

\section{UMA ROTA DE RECUPERAÇÃO DE METAL A PARTIR DE ESCÓRIA SECUNDÁRIA DA PRODUÇÃO DE FERRONÍQUEL}

Dissertação apresentada à Escola

Politécnica da Universidade de São Paulo para a obtenção do título de Mestre em Engenharia

Área de Concentração: Engenharia Mineral

Orientador: Prof. Dr. Arthur Pinto Chaves

São Paulo

2009 


\section{FICHA CATALOGRÁFICA}

\section{Richter, Douglas}

Uma rota de recuperação de metal a partir de escória secundária da produção de ferroníquel / D. Richter. -- São Paulo, 2009. $122 \mathrm{p}$.

Dissertação (Mestrado) - Escola Politécnica da Universidade de São Paulo. Departamento de Engenharia de Minas e de Petróleo.

1. Processamento de minerais metálicos 2. Níquel 3. Rejeitos de mineração (Reaproveitamento) I.Universidade de São Paulo. Escola Politécnica. Departamento de Engenharia de Minas e de Petróleo II.t. 
DEDICATÓRIA

À vida. 


\section{AGRADECIMENTOS}

Ao Prof. Dr. Arthur Pinto Chaves, pelos conselhos e pelo compartilhar de extenso conhecimento técnico que permitiram o desenvolvimento desta Dissertação. Ao Prof. Dr. Homero Delboni Jr., pela orientação que resultou nas formas iniciais deste trabalho.

Aos professores e funcionários do Departamento de Engenharia de Minas e de Petróleo da Escola Politécnica da USP, em especial à Eng. Bianca Foggiatto, aos técnicos de Laboratório Alfredo, André (ex-officio), Junior e Rogério, e à Maria Cristina Bonesio, cuja tolerância para com atrasos na devolução de livros foi peça-chave para a criação deste texto num prazo aceitável.

Meus maiores e sinceros agradecimentos, estima e consideração aos amigos e colegas da Progen, especialmente Eng. Carlos Leonel Imenes (ex-officio), que foi mais que chefe e acreditou em mim quando nem eu acreditava, e Eng. Pietr Castelo Chaves, pela contribuição final a este trabalho.

Um eterno obrigado aos colegas e amigos da IGEO, Eng. Gustavo Ventrella Duran, Eng. Laurindo Almeida e Eng. Pedro Paulo Batista, e da Morro Azul, Eng. Claudio Belluzzo, que tornaram este trabalho possível e economicamente viável.

Aos amigos e colegas de tantos anos de Poli, especialmente Eng. Heitor Honda Federico, pelos comentários, pelas críticas, pelas "pedaladas", pelas conversas depois da meia-noite, pelos inúmeros milk-shakes no "Necroburger" - enfim, por absolutamente tudo.

À minha família - meus pais, meus irmãos e meu filho -, pois nada nos últimos 28 anos teria feito sentido se vocês não existissem. 
„Wichtig ist, dass man nicht aufhört zu fragen“

(O importante é nunca deixar de perguntar)

(Albert Einstein) 


\section{RESUMO}

A produção de ferroníquel está intimamente ligada à indústria siderúrgica. Todas as operações pirometalúrgicas pertencentes à rota de processo (calcinação, redução e refino) visam o melhor aproveitamento energético e a menor quantidade de impurezas no produto final. A etapa de refino pirometalúrgico produz escória rica em ferro e níquel, que normalmente é processada para recuperação destes metais e reinserção no processo, na própria etapa de refino ou no forno de redução, dependendo da quantidade de impurezas. Ensaios realizados com a escória granulada da Mineração Morro Azul mostram que é possível recuperá-los por processos físicos, de maneira similar à existente no local, porém com resultados superiores, mediante algumas alterações propostas para o circuito.

Palavras-chave: ferroníquel, escória, processamento de minérios, concentração, processamento de escória. 


\begin{abstract}
Ferronickel production is intimately connected to the steel industry. All pyrometallurgical operations which comprise the process route (calcining, smelting, refining) aim at better energetic usage and smaller amount of impurities in the final product. The pyrometallurgical refining stage produces slag rich in iron and nickel, which is usually further processed for metal recovery and reinsertion back into the process, in the refining or smelting stages, depending on the amount of impurities. A series of tests carried out on the Mineração Morro Azul granulated refining slag shows that it is possible to recover the metallic particles through physical processing, similarly to the existing facility, but with improved results due to some alterations proposed for the circuit.
\end{abstract}

Keywords: ferronickel, slag, mineral processing, concentration, metal recovery. 


\section{LISTA DE ILUSTRAÇÕES}

Figura 1.1 - Preços do níquel na LME (site InfoMine.com).

Figura 2.1 - Equipamentos de cominuição e suas aplicações (adaptado de KELLY; SPOTTISWOOD, 1982).

Figura 2.2 - Aplicações dos modelos de energia de quebra (adaptado de FIGUEIRA; ALMEIDA; DA LUZ, 2004).

Figura 2.3 - Britador Dodge (esquerda) e Blake (direita) (METSO, 2005).

Figura 2.4 - Britador de rolo único (catálogo da PCC).

Figura 2.5 - Britador de martelos (catálogo da PCC).

Figura 2.6 - Operação em cascata (A) e catarata (B) (adaptado de KELLY; SPOTTISWOOD, 1982).

Figura 2.7 - Mecanismos de separação gravítica (adaptado de LINS, 2004).

Figura 2.8 - Comportamento de uma partícula em escoamento laminar (apud CHAVES, s/d).

Figura 2.9 - Funcionamento de uma mesa vibratória (LINS, 2004).

Figura 2.10 - Mesa Mozley.

Figura 2.11 - Operação de um jigue (LINS, 2004).

Figura 2.12 - Arranjo final do leito do jigue (CHAVES, s/d).

Figura 2.13 - Jigue moderno (adaptado de CHAVES, s/d).

Figura 2.14 - Jigue PanAmerican.

Figura 2.15 - Equipamento de ensaio afunda-flutua.

Figura 2.16 - Comportamento de minerais sob ação de campo magnético (adaptado de SAMPAIO; DA LUZ, 2004).

Figura 2.17 - Rotas de processamento para obtenção de níquel.

Figura 2.18 - Diagrama de fases $\mathrm{SiO}_{2}-\mathrm{MgO}-\mathrm{NiO}$ (DEGEL, 2006).

Figura 2.19 - A rota RKEF.

Figura 2.20 - Seção transversal de um forno rotativo (adaptado de HEYDENRYCH, 2001).

Figura 2.21 - Seção transversal de forno a arco (DEGEL, 2006).

Figura 2.22 - Correlação entre temperatura e condutividade elétrica da escória (SOUZA SANTOS, 1960; SILVEIRA, 1997; DEGEL, 2006).

Figura 2.23 - Panela posicionada para lingotamento na Morro Azul.

Figura 2.24 - Descarga da lingoteira da Morro Azul.

Figura 2.25 - Granulação de metal da Codemin.

Figura 2.26 - Secagem e peneiramento de metal da Morro Azul.

Figura 2.27 - Granulação de escória da etapa de redução da Codemin.

Figura 2.28 - Granulação de escória do refino da Morro Azul. 
Figura 2.29 - Circuito de recuperação de metal a seco típico.

Figura 3.1 - Macrolocalização do Morro do Ferro (adaptado de FERNANDES et al., 2003).

Figura 3.2 - Microlocalização do Morro do Ferro (adaptado de FERNANDES et al., 2003).

Figura 3.3 - Corrida de metal do forno, com peneira de ferroníquel à esquerda.

Figura 3.4 - Transferência de metal da panela para o conversor ao fundo, com estação de pré-aquecimento à frente e à esquerda.

Figura 3.5 - Escória retirada do conversor.

Figura 3.6 - Vista da usina de recuperação de metal, com a britagem primária no ponto mais alto e a secundária no patamar intermediário, antes da moagem.

Figura 3.7 - Vista do piso baixo da moagem, com a jigagem à frente.

Figura 4.1 - Preparação de alíquotas para determinação de granulometria.

Figura 4.2 - Britagem de alíquotas.

Figura 4.3 - Moagem de alíquotas.

Figura 4.4 - Britador de rolos utilizado nos trabalhos.

Figura 4.5 - Moinho de barras utilizado nos trabalhos.

Figura 4.6 - Moinho padrão para teste de WI.

Figura 4.7 - Mesa Mozley utilizada nos ensaios.

Figura 5.1 - Escória granulada tal qual, com escória resfriada como escala.

Figura 5.2 - Escória resfriada tal qual.

Figura 5.3 - Distribuição granulométrica da amostra granulada tal qual.

Figura 5.4 - Distribuição granulométrica da amostra resfriada tal qual.

Figura 5.5 - Moinho de barras utilizado na preparação de amostras.

Figura 5.6 - Distribuição granulométrica da amostra granulada moída.

Figura 5.7 - Fragmentos metálicos da amostra granulada moída.

Figura 5.8 - Amostra resfriada, aparência geral.

Figura 5.9 - Espectro do ponto P1.

Figura 5.10 - Amostra resfriada (detalhe).

Figura 5.11 - Amostra resfriada (detalhe).

Figura 5.12 - Amostra resfriada (detalhe).

Figura 5.13 - Amostra resfriada (detalhe).

Figura 5.14 - Espectro do ponto P10.

Figura 5.15 - Amostra resfriada (detalhe).

Figura 5.16 - Amostra resfriada (detalhe).

Figura 5.17 - Amostra granulada, aspecto geral.

Figura 5.18 - Amostra granulada (detalhe).

Figura 5.19 - Espectro do ponto P3. 
Figura 5.20 - Amostra granulada (detalhes).

Figura 5.21 - Espectro do ponto P5.

Figura 5.22 - Espectro do ponto P6.

Figura 5.23 - Amostra granulada (detalhe).

Figura 5.24 - Ensaio realizado no béquer.

Figura 5.25 - Ensaio realizado na mesa Mozley.

Figura 5.26 - Realização de análises químicas por via úmida. 


\section{LISTA DE TABELAS}

Tabela 2.1 - Índices de trabalho típicos de diversos materiais, em kWh/st (adaptado de KELLY; SPOTTISWOOD, 1982).

Tabela 2.2 - Carga inicial de barras, porcentagem em peso retida simples.

Tabela 2.3 - Carga inicial de bolas, porcentagem em peso retida simples.

Tabela 2.4 - Critério de concentração e comportamento do processo.

Tabela 2.5 - Classes de suspensões (CAMPOS; DA LUZ; CARVALHO, 2004).

Tabela 2.6 - Susceptibilidade magnética de alguns minerais.

Tabela 2.7 - Tipos de equipamentos de separação magnética.

Tabela 2.8 - Ocorrências minerais e suas respectivas rotas de processo (TERRY; MONHEMIUS; BURKIN, 1987; DALVI; BACON, OSBORNE, 2004).

Tabela 2.9 - Produção e reservas de níquel (KUCK, 2006).

Tabela 2.10 - Sistemas de britagem de usinas de ferroníquel brasileiras.

Tabela 2.11 - Sistemas de britagem de usinas de ferroníquel estrangeiras.

Tabela 4.1 - Alíquotas para caracterização física.

Tabela 5.1 - Distribuição granulométrica da escória granulada tal qual.

Tabela 5.2 - Distribuição granulométrica da amostra resfriada tal qual.

Tabela 5.3 - Resultado do peneiramento da escória granulada moída.

Tabela 5.4 - Análises químicas por XRF.

Tabela 5.5 - Análise química da escória granulada por via úmida.

Tabela 5.6 - Distribuição granulométrica da alimentação, escória resfriada.

Tabela 5.7 - Parâmetros de teste, escória resfriada.

Tabela 5.8 - Planilha do teste de WI, escória resfriada.

Tabela 5.9 - Distribuição granulométrica da carga circulante, escória resfriada.

Tabela 5.10 - Distribuição granulométrica do produto final, escória resfriada.

Tabela 5.11 - Resultados do teste, escória resfriada.

Tabela 5.12 - Distribuição granulométrica da alimentação, escória granulada.

Tabela 5.13 - Parâmetros de teste, escória granulada.

Tabela 5.14 - Planilha do teste de WI, escória granulada.

Tabela 5.15 - Distribuição granulométrica da carga circulante, escória granulada.

Tabela 5.16 - Distribuição granulométrica do produto final, escória granulada.

Tabela 5.17 - Resultados do teste, escória granulada.

Tabela 5.18 - Ensaios de líquido denso.

Tabela 5.19 - Distribuições de massas dos ensaios com líquido denso.

Tabela 5.20 - Distribuições de massas dos ensaios com mesa Mozley.

Tabela 5.21 - Análises químicas das frações flutuadas. 
Tabela 5.22 - Análises químicas das frações afundadas.

Tabela 5.23 - Análises químicas do concentrado.

Tabela 5.24 - Análises químicas do rejeito.

Tabela 5.25 - Recuperações do flutuado (líquido denso).

Tabela 5.26 - Recuperações do afundado (líquido denso).

Tabela 5.27 - Recuperações do concentrado (mesa Mozley).

Tabela 5.28 - Recuperações do rejeito (mesa Mozley).

Tabela 5.29 - Enriquecimentos (mesa Mozley). 


\section{LISTA DE EQUAÇÕES}

Eq. (1) Primeira Lei da Fragmentação (Lei de Kick)

Eq. (2) Segunda Lei da Fragmentação (Lei de Rittinger)

Eq. (3) Terceira Lei da Fragmentação (Lei de Bond)

Eq. (4) Velocidade crítica do moinho

Eq. (5) Fator de enchimento do moinho

Eq. (6) Critério de concentração simplificado

Eq. (7) Critério de concentração corrigido por Burt

Eq. (8) Relação entre freqüência e amplitude da pulsação de um jigue

Eq. (9) Relação entre densidade e intensidade do campo magnético

Eq. (10) Densidade e intensidade do campo magnético sob presença de material

Eq. (11) Relação entre indução magnética do material e magnetização

Eq. (12) Redução de óxido de níquel

Eq. (13) Redução de óxido de cobre

Eq. (14) Redução de óxido de cobalto

Eq. (15) Redução de óxido de ferro(III)

Eq. (16) Formação de magnetita

Eq. (14) Redução de óxido de cobalto

Eq. (15) Redução de óxido de ferro(III)

Eq. (16) Formação de magnetita

Eq. (17) Cálculo da massa específica aparente

Eq. (18) Determinação da carga do moinho

Eq. (19) Cálculo do IPP

Eq. (20) Determinação do produto líquido por rotação

Eq. (21) Cálculo do novo número de rotações do moinho

Eq. (22) Cálculo do WI 


\section{LISTA DE SIGLAS}

ABM Associação Brasileira de Metalurgia e Materiais

AHL Acid Heap Leaching

AIME American Institute of Mining, Materials, Metallurgical and Petroleum Engineers

$\mathrm{AL} \quad$ Atmospheric Leaching

BNDES Banco Nacional para o Desenvolvimento Econômico e Social

CL Chloride Leaching

EC Environment Canada

GLP Gás Liquefeito de Petróleo

HPAL High pressure acid leach

HPGR High pressure grinding roll

INSG International Nickel Study Group

JKMRC Julius Kruttschnitt Mineral Research Centre

LD Linz-Donawitz

LME London Metals Exchange

MEV Microscopia Eletrônica de Varredura

MGS Multi Gravity Separator

PAL Pressure acid leach

PCC Pennsylvania Crusher Corporation

PDAC Prospectors and Developers Association of Canada

ROSE Radar Operated Separation Equipment

RKEF Rotary kiln-electric furnace

RTZ Rio Tinto Zinc

SAIMM South African Institute of Mining and Metallurgy

SME Society of Manufacturing Engineers

USGS United States Geological Survey

XRF X-Ray Fluorescence 


\section{LISTA DE SÍMBOLOS}

a amplitude da pulsação do leito do jigue, em $\mathrm{mm}$

Al índice de abrasão (abrasion index), adimensional

$B$ densidade de fluxo magnético, em $T$

C carga do moinho para determinação de WI, em g

CC critério de concentração, adimensional

D diâmetro do moinho, interno ao revestimento, em m

d diâmetro da esfera equivalente à partícula, em $\mathrm{mm}$

$\mathrm{d}_{\mathrm{b}}$ diâmetro máximo das bolas, em $\mathrm{mm}$

$d_{c a}$ espessura da camada ativa, em $\mathrm{mm}$

$d_{r}$ diâmetro máximo das barras, em mm

$\mathrm{d}_{80}$ diâmetro característico no qual passa $80 \%$ da população, em $\mu \mathrm{m}$

$F$ tamanho da alimentação

$F_{f}$ fator de enchimento do moinho, em \%

$\mathrm{F}_{80}$ tamanho de tela no qual passa $80 \%$ da alimentação, em $\mu \mathrm{m}$

f freqüência de pulsação do jigue, em pulsos/min

$f_{c s}$ fração da velocidade crítica do moinho, adimensional no intervalo [0; 1]

$\mathrm{H}$ intensidade do campo magnético, em $\mathrm{T}$

$\mathrm{h}_{\mathrm{c}}$ distância do topo do interior do moinho/calcinador ao leito de carga, em $\mathrm{m}$ IPP ideal period product, em $\mathrm{g}$

$\mathrm{J}$ magnetização de um material, em $\mathrm{T}$

$\mathrm{K}$ fração passante da alimentação na malha de teste (WI), adimensional no intervalo $[0 ; 1]$

$\mathrm{K}_{\mathrm{K}}$ constante de Kick, adimensional

$K_{R}$ constante de Rittinger, adimensional

$\mathrm{L}$ comprimento do moinho, interno ao revestimento, em $\mathrm{m}$

$\mathrm{M}$ malha do teste de determinação de WI, em $\mu \mathrm{m}$ (ou produto retido na malha de teste, em g)

$P$ tamanho do produto

$\mathrm{P}_{80}$ tamanho de tela no qual passa $80 \%$ do produto, em $\mu \mathrm{m}$

$\mathrm{Q}$ número de rotações do moinho de teste de $\mathrm{WI}$, adimensional

$\mathrm{Q}_{\mathrm{a}}$ número de rotações do ciclo anterior do moinho de teste de WI, adimensional

$\mathrm{R}$ raio do calcinador, em $\mathrm{m}$ (ou complementação da carga de teste de $\mathrm{Wl}$, em g)

$\mathrm{Rr}$ relação de redução, adimensional

$\mathrm{S}$ massa da carga exceto a retida na malha do teste, em $\mathrm{g}$

$\mathrm{T}$ massa de produto, em $\mathrm{g}$ 
$\mathrm{U}$ massa de produto líquida, em $\mathrm{g}$

$\checkmark$ massa de produto líquida por rotação, em g/rotação

$V_{\mathrm{cs}}$ velocidade crítica do moinho, em rpm

$W$ energia específica de cominuição, em $\mathrm{kWh} / \mathrm{st}$

WI work index de Bond, em $\mathrm{kWh} / \mathrm{st}$

$X$ média da complementação da carga dos últimos 2 períodos, em $\mathrm{g}$

$x$ distância ao longo da camada ativa onde se mede sua espessura, em $\mathrm{m}$

Z carga circulante do teste de WI, adimensional no intervalo $[0 ; 1]$

$\gamma_{\mathrm{ap}}$ massa específica aparente, em lb/ft ${ }^{3}$ (determinação de WI)

$\mu$ permeabilidade magnética do meio, em T.m/A

$\rho_{1}$ densidade da partícula $1^{1}$

$\rho_{2}$ densidade da partícula 2

$\rho_{\mathrm{s}}$ densidade do sólido

$\Psi$ indução magnética do material, em T

$\omega$ rotação do forno, em rad/s 


\section{SUMÁRIO}

1. INTRODUÇÃO.................................................................... 4

1.1. OCORRÊNCIA NA NATUREZA

1.2. MERCADO

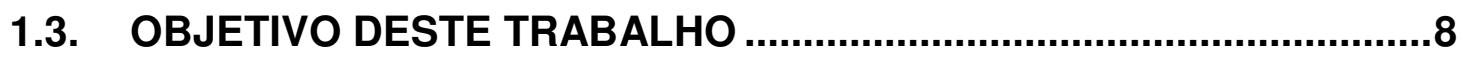

2. REVISÃO TEÓRICA ............................................................... 9

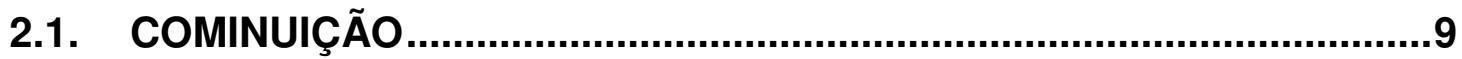

2.1.1. ENERGIA DE QUEBRA ...................................................11

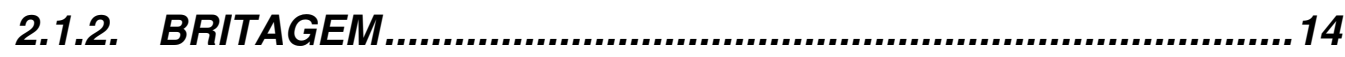

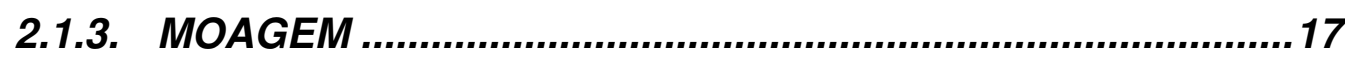

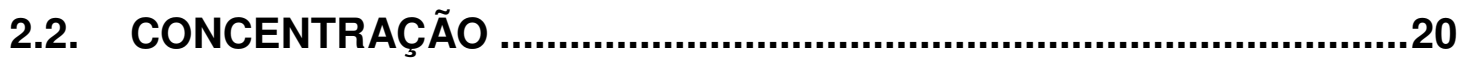

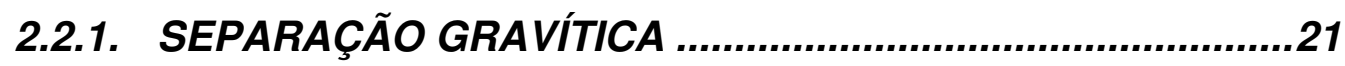

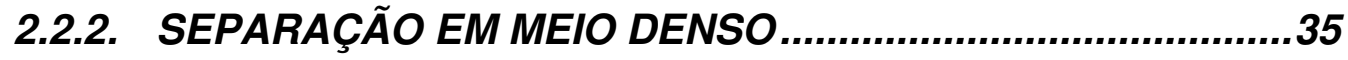

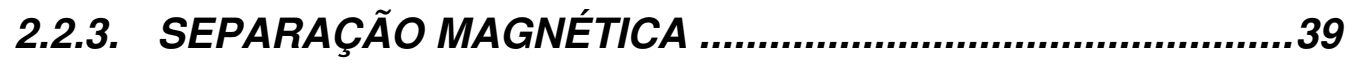

2.3. A PRODUÇÃO DE FERRONÍQUEL............................................44

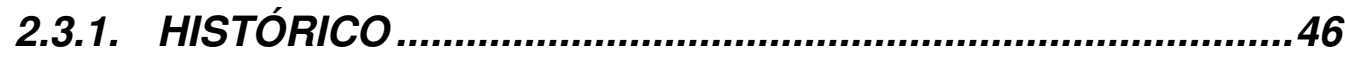

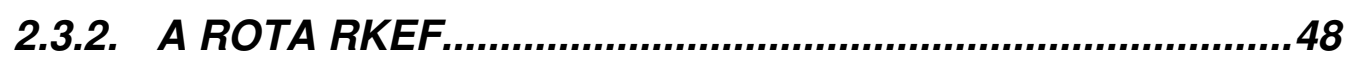

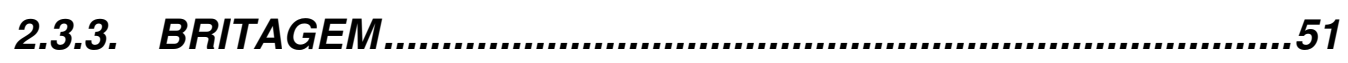

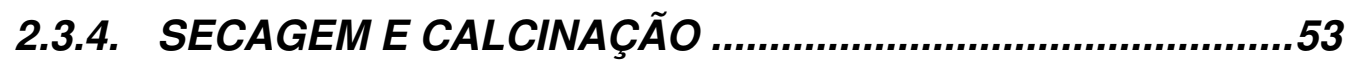

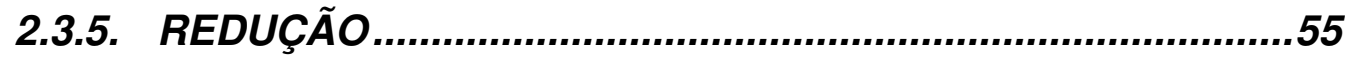

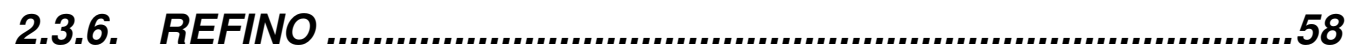

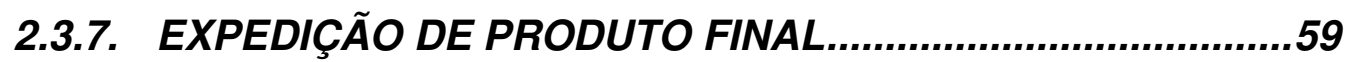

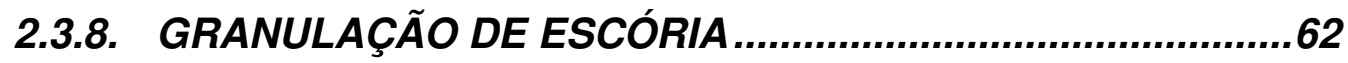

2.3.9. PROCESSAMENTO DE ESCÓRIA DO REFINO...................64

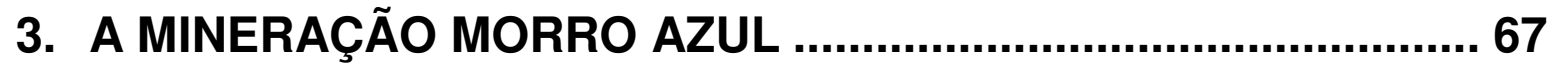

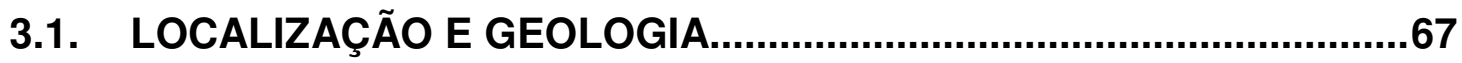

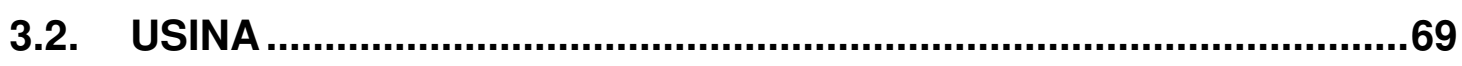

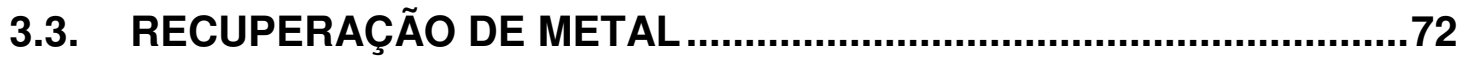

4. MATERIAIS E MÉTODOS ...................................................... 75

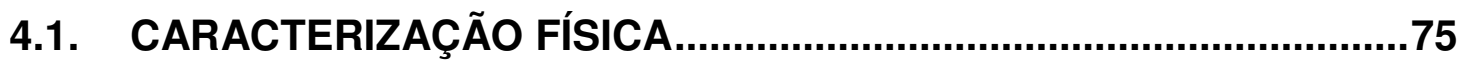

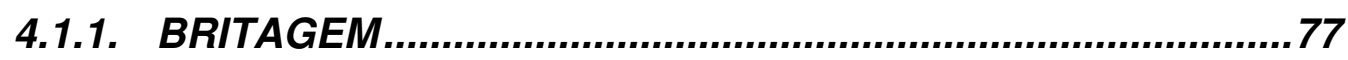

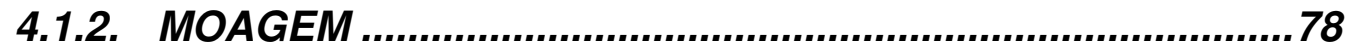

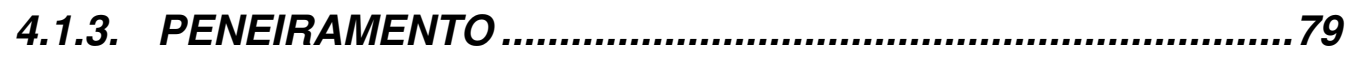

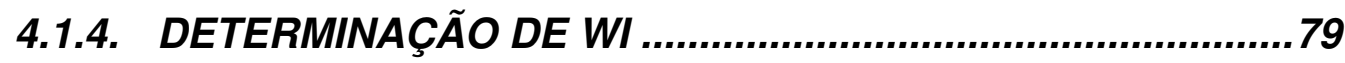

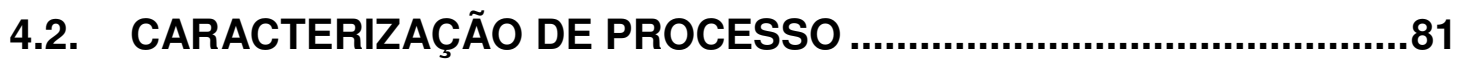




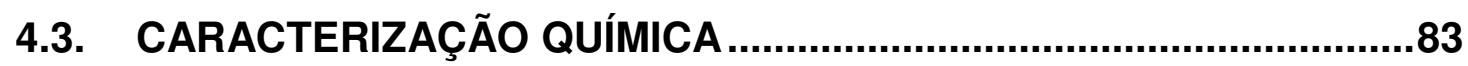

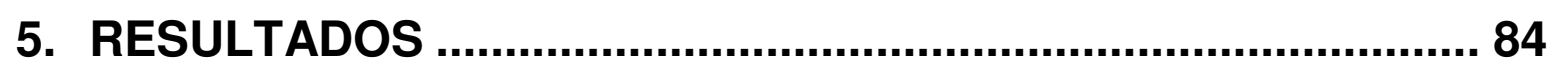

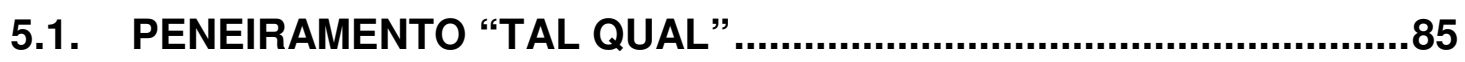

5.2. MICROSCOPIA ELETRÔNICA DE VARREDURA............................90

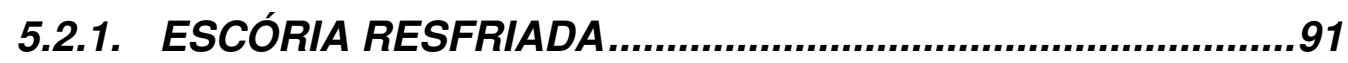

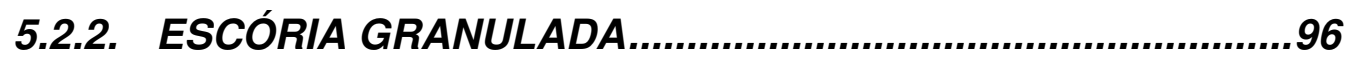

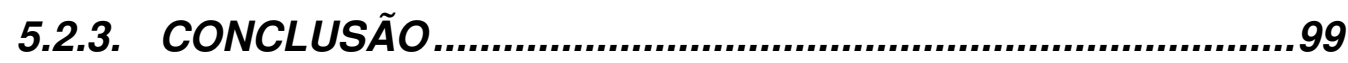

5.3. DETERMINAÇÃO DOS ÍNDICES DE TRABALHO (WI) ..................100

5.3.1. ESCÓRIA RESFRIADA.................................................100

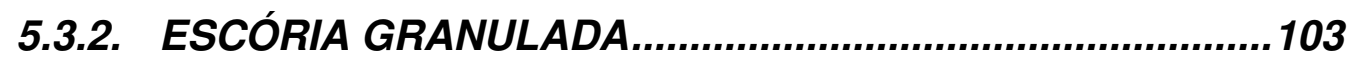

5.4. ENSAIOS COM LÍQUIDO DENSO ............................................105

5.5. ENSAIOS EM MESA MOZLEY..................................................107

5.6. SEPARAÇÃO MAGNÉTICA E ANÁLISES QUÍMICAS ...................109

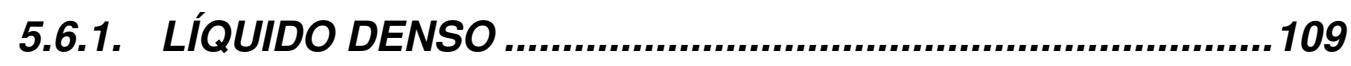

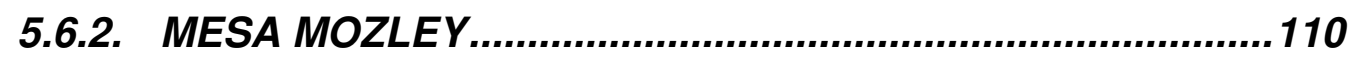

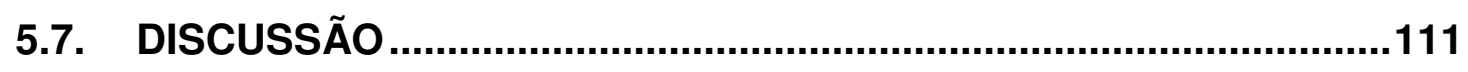

6. CONSIDERAÇÕES FINAIS ................................................ 115

REFERÊNCIAS BIBLIOGRÁFICAS ........................................ 117 


\section{INTRODUÇÃO}

O desenvolvimento da China como potência econômica e sua conseqüente demanda por recursos minerais iniciou um ciclo de mudanças intenso em todo o mundo. Um efeito dessa conjuntura foi a alta dos preços das commodities, que atingiram níveis recordes nos últimos 5 anos (ROGOFF, 2008). Dentre elas, destaca-se o níquel, cujo preço ultrapassou US\$20/lb em 2007, chegando a atingir US\$24/lb (KOSICH, 2007). Em 2008, chegou a valores ainda maiores, numa situação atípica que, entretanto, encorajou muitos investidores a implantarem novos projetos, como será comentado adiante.

O níquel é um dos elementos mais abundantes do universo, é muito abundante no magma terrestre, mas representa apenas $0,016 \%$ da crosta (embora uma das camadas do centro da terra seja designada como Nife, exatamente devido à abundância deste elemento e do ferro). Desta forma, há poucos depósitos que podem ser aproveitados economicamente. $O$ níquel é muito abundante em meteoritos. Como estes corpos celestes são também ricos em ferro, sua composição aproxima-se da de aços inoxidáveis. Por isto, em tempos passados, eram utilizados para forjar espadas e outros utensílios. Aliás, o termo "siderurgia" é oriundo do latim sideris, que significa céu, lugar de origem destes meteoritos (ROSEMBERG, 1968; TERRY; MONHEMIUS; BURKIN, 1987).

Seu uso data da época dos caldeus. Nos tempos modernos, os primeiros usos referem-se ao "cobre branco" e datam de 1597. Já em 1845, E. Thomason forjava ligas com uma composição de $40 \% \mathrm{Cu}, 31 \% \mathrm{Ni}, 26 \%$ Zn e 3\% Fe (ROSEMBERG, 1968). No final do século XIX, J. Riley iniciou seu trabalho em melhorar as propriedades mecânicas dos aços contendo níquel, o que resultou no desenvolvimento de um grande nicho de mercado já no início do século $X X$ (VOLK, 1970). 
Em trabalho publicado em 1804, o professor Jeremias Benjamin Richter assim descreveu o níquel (ROSEMBERG, 1968):

- "Sua coloração encontra-se no meio do caminho entre a da prata e a do estanho puro";

- "Não é afetado pelo ar ou pela água atmosférica, ou seja, não enferruja";

- "Barras podem ser feitas de níquel quando este é aquecido e pode-se transformá-lo novamente em placas quando resfriado. Por causa disso, não pode ser considerado um semi-metal e toma seu lugar de metal 'perfeito";

- "Seu peso específico ou densidade é 8,279 quando derretido e 8,666 quando completamente fundido. Sua resistência é considerável";

- "Possui alto ponto de fusão e, portanto, é muito difícil de derretê-lo, pelo menos tão difícil quanto o manganês";

- "O metal oxidou-se muito pouco quando aquecido até ficar vermelho, quando fica um pouco mais opaco que platina, prata ou ouro. Portanto, não é apenas um metal 'perfeito', mas um metal 'nobre'”;

- "A ação de ímãs no níquel é muito grande, apenas um pouco menor que no ferro".

Estas características tornaram-no objeto de interesse da humanidade para as mais diversas aplicações industriais.

\subsection{OCORRÊNCIA NA NATUREZA}

Os depósitos de níquel podem ser de origem magmática ou residual. As jazidas magmáticas são também chamadas de sulfetadas e "estão associadas a eventos tardi-magmáticos relacionados a complexos ultramáficos" (MANO, 2002). Hoje, estes depósitos representam $20 \%$ das reservas e $55 \%$ da produção mundial. Os maiores depósitos encontram-se no Canadá e na Rússia (ROSEMBERG, 1968; VOLK, 1970; TERRY; MONHEMIUS; BURKIN, 1987; BNDES, 2000).

Já as jazidas residuais são constituídas por material extremamente alterado pelas intempéries. Possuem como fonte as rochas ultrabásicas e são chamadas de 
lateríticas. Normalmente são encontradas na região dos trópicos e representam $80 \%$ das reservas e $45 \%$ da produção mundial (MANO, 2002). Os países e regiões do mundo que fazem uso de reservas deste tipo são (em seqüência decrescente de produção): Nova Caledônia, Austrália, Brasil, Indonésia, Filipinas e Cuba (BNDES, 2000; MANO, 2002).

É importante ressaltar que, quase como regra geral, os minérios oxidados são utilizados para fabricar ferroníquel e os sulfetados, para fabricar níquel metálico. Todavia, isto depende da composição química do minério particular, como será abordado adiante. Normalmente, os minerais de níquel encontram-se associados a minerais silicatados secundários, e o níquel costuma substituir o magnésio em alguns minerais primários (olivina, hiperstênio, hornblenda e biotita). Não é possível encontrar níquel nativo puro na natureza (ROSEMBERG, 1968).

\subsection{MERCADO}

Apesar do desenvolvimento das primeiras ligas de níquel no início do século XIX, a produção comercial de níquel somente se iniciou em 1875, com o desenvolvimento dos primeiros depósitos lateríticos da Nova Caledônia, seguido pela abertura das minas de sulfetados em Sudbury, no Canadá (TERRY; MONHEMIUS; BURKIN, 1987).

Na década de 1950, o Canadá já havia se tornado o maior produtor de níquel do mundo não-comunista, seguido de outros produtores menores à época: URSS, Cuba e Nova Caledônia. Os preços do níquel eram ditados pelas descobertas de jazidas no Canadá e pela variação nos custos de produção. Já na década de 1980, este rol passou a abrigar 25 países, como Austrália, Brasil, Colômbia, EUA, Filipinas, Grécia, Guatemala, Indonésia, lugoslávia e República Dominicana (TERRY; MONHEMIUS; BURKIN, 1987).

$\mathrm{Na}$ década de 1990, diversos projetos foram paralisados ou tiveram suas capacidades de produção reduzidas. A partir de 1999 (figura 1.1) os preços 
reagiram. Como conseqüência, muitos estudos de viabilidade técnico-econômica, expansões e reformas em instalações existentes foram realizadas, resultando em preços nunca antes vistos para a commodity.

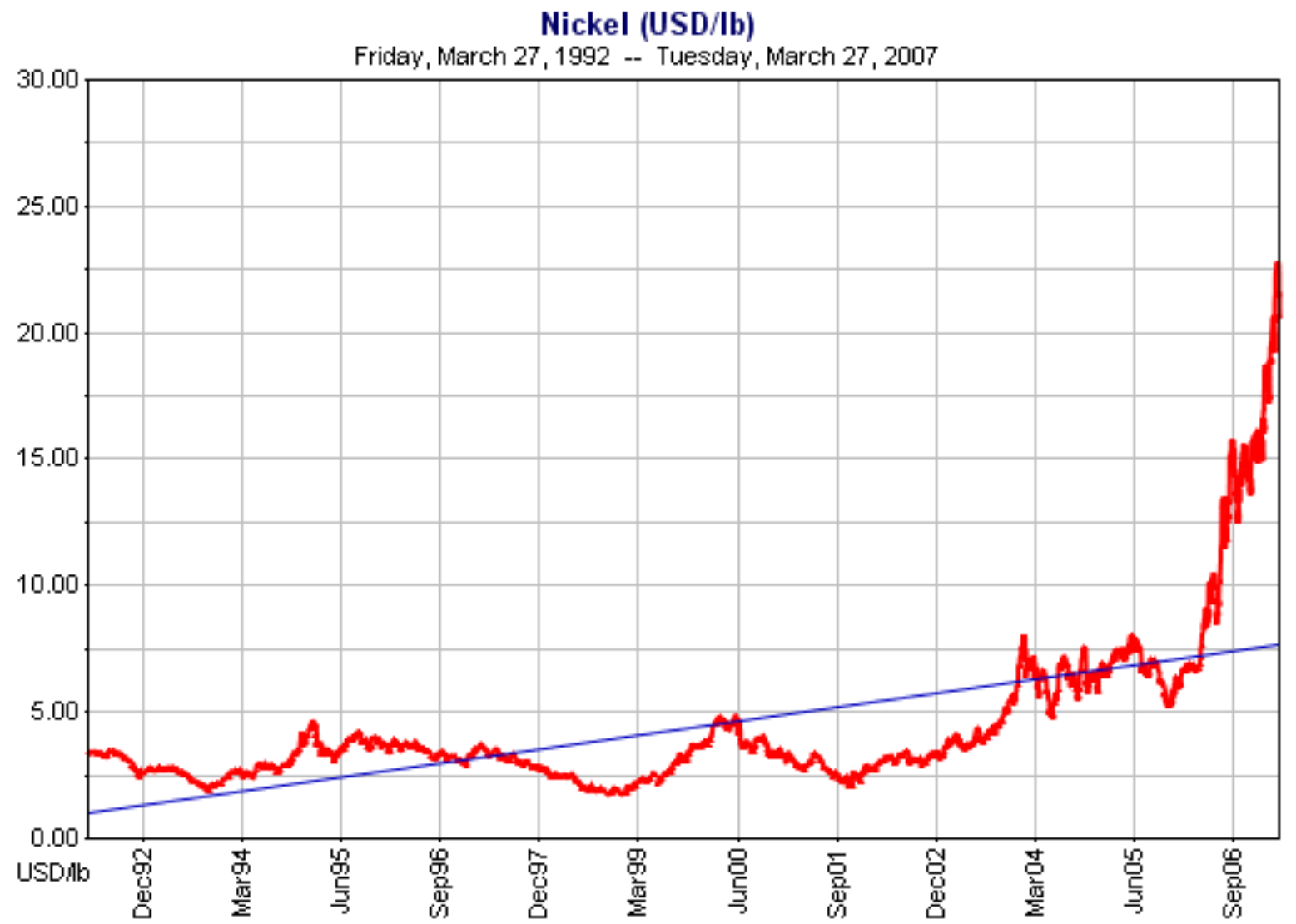

Figura 1.1 - Preços do níquel na LME (site InfoMine.com).

O principal fomentador desse cenário era a expansão econômica da China, que demandava muito da indústria de base. Isto motivou muitas fusões, aquisições (a aquisição da PT Inco pela CVRD e da Falconbridge pela Xstrata) e novos projetos (Onça Puma, Barro Alto, Mirabela, etc.) (BNDES, 2000). Em 2007, confirmando as previsões de $\mathrm{KOSICH}$ (2007), iniciou-se uma seqüência de fatos relacionados à crise imobiliária nos EUA que derrubou os preços das commodities, quebrou bancos (como o Lehman Brothers, em setembro de 2008) e paralisou usinas em operação e projetos (FRANK, 2009; GIANNONE, 2009; NORTON, 2009). 
Junto com as commodities, foram derrubados também os preços do petróleo, diminuindo alguns dos principais custos operacionais de uma usina de ferroníquel, relacionados à combustão no forno de calcinação e à energia elétrica consumida no forno de redução. Apesar da queda de demanda mundial por metais básicos, principalmente devido à quase paralisação das atividades relacionadas à indústria automobilística, a redução dos custos operacionais acabou por evitar um colapso na indústria do ferroníquel, preparando-a para reassumir o lugar de destaque que assumira nos últimos anos. Espera-se que isto ocorra no médio prazo, tendo em vista os fatores intrínsecos de uma jazida mineral (economicidade, tamanho) e os de processo (melhora de recuperação metalúrgica, economia de custos operacionais).

\subsection{OBJETIVO DESTE TRABALHO}

Esta dissertação observa a recuperação global de níquel de uma usina de ferroníquel, a partir da escória da operação de refino da Mineração Morro Azul, antiga Morro do Níquel, localizada em Fortaleza de Minas (MG). A partir disso, objetiva-se verificar a eficácia da operação atual da Morro e eventualmente sugerir melhorias de processo.

O foco principal deste trabalho será, portanto, o desenvolvimento e a escolha da melhor rota técnica para esta escória especificamente. Este método poderá ser utilizado para o desenvolvimento de rotas adequadas a outras plantas. 


\section{REVISÃO TEÓRICA}

Este capítulo aborda os fundamentos teóricos envolvidos no desenvolvimento deste trabalho.

\subsection{COMINUIÇÃO}

No âmbito do Tratamento de Minérios, cominuição é o "conjunto de operações de redução de tamanhos, executado de maneira controlada e de modo a cumprir um objetivo pré-determinado" (CHAVES; PERES, 2006). Estes objetivos podem ser (KELLY; SPOTTISWOOD, 1982):

- adequar tamanho ou forma de partículas;

- liberar minerais de valor da ganga para possibilitar a concentração ulterior;

- gerar área específica para facilitar a reação química.

Os mecanismos que realizam cominuição nas etapas de processamento são a compressão, o impacto, o atrito e a abrasão (FIGUEIRA; ALMEIDA; DA LUZ, 2004), sendo os dois primeiros presentes principalmente na britagem e os dois últimos na moagem.

Motivados pelo aumento das escalas de produção e pelas crescentes necessidades de redução de custos de implantação e operacionais, os equipamentos de britagem e moagem evoluíram muito nos últimos 50 anos (KELLY; SPOTTISWOOD, 1982). Ainda assim, alguns conceitos, comuns a toda operação de cominuição, precisam ficar claramente definidos (CHAVES; PERES, 2006):

- relação de redução $(\mathrm{Rr})$ : é a razão entre o tamanho da alimentação e o tamanho do produto, normalmente expresso pelas aberturas de peneira por onde passa $80 \%$ da massa total; 
- circuito fechado: aquele onde uma ou mais operações de classificação controlam o tamanho produzido pelo circuito, podendo ser normal (classificação posterior à cominuição) ou reverso (classificação anterior a ela);

- circuito aberto: aquele que opera sem classificação.

Dificilmente a cominuição é realizada em estágio único. O tipo de equipamento selecionado para cada estágio (primário, secundário ou terciário) é definido em função das características físicas (distribuição granulométrica, dureza, resistência à compressão, abrasividade), químicas (composição) e mineralógicas da alimentação, das características do produto desejado e da vazão necessária à operação. A figura 2.1 mostra como algumas dessas características se relacionam com o tipo de equipamento e/ou operação desejada.

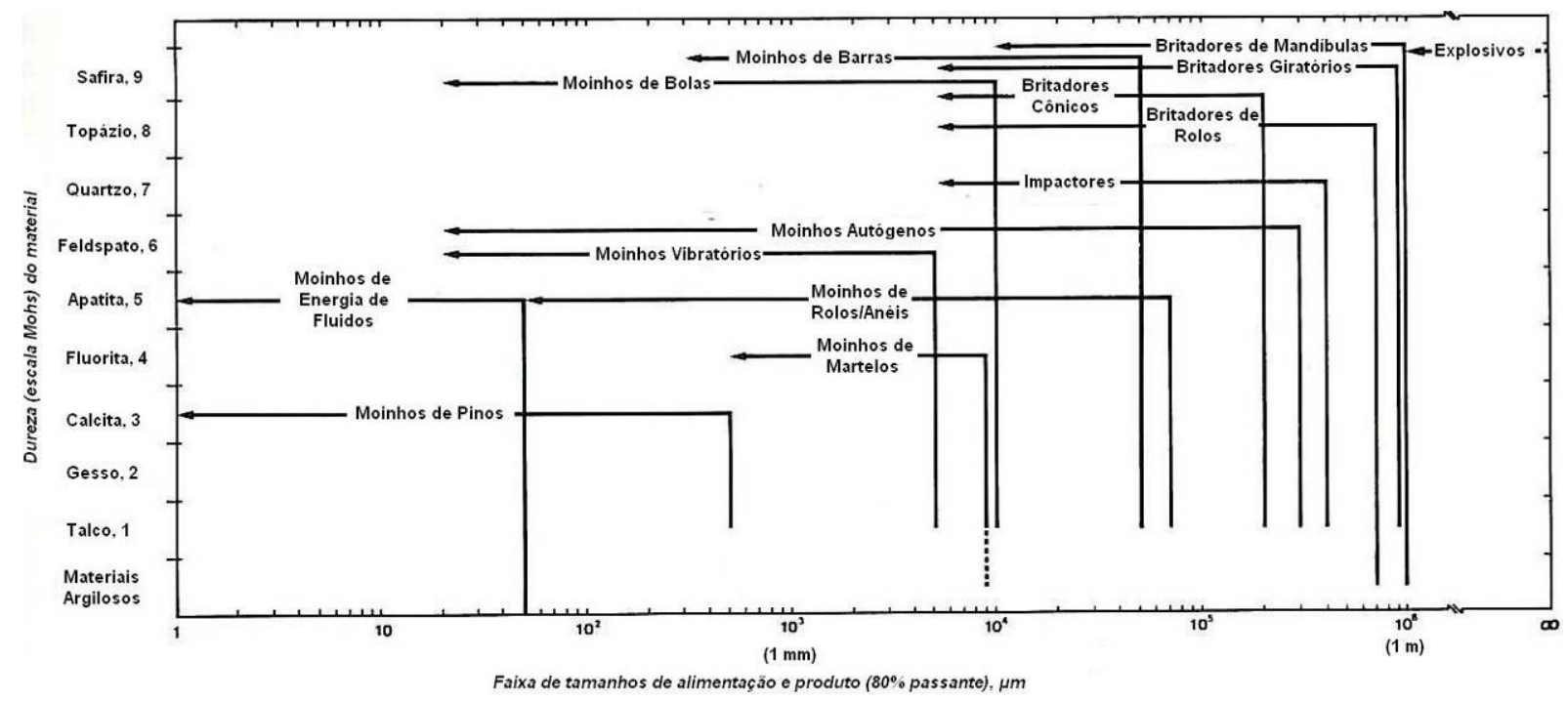

Figura 2.1 - Equipamentos de cominuição e suas aplicações (adaptado de KELLY; SPOTTISWOOD, 1982).

Tanto a britagem quanto a moagem possuem objetivos e papéis diferentes no circuito de cominuição. Estes aspectos serão abordados a seguir. 


\subsubsection{ENERGIA DE QUEBRA}

Este assunto foi objeto de estudo e intenso debate científico no início do século XX (DELBONI JR., 2007). Em momentos muito próximos (por volta de 1865), foram apresentadas nos EUA e na Alemanha as duas primeiras relações entre a energia de quebra necessária e as características do material. F. Kick postulou: "o trabalho requerido é proporcional à redução em volume das partículas envolvidas". A expressão da lei é:

$$
W=K_{K} * \log \frac{F}{P}
$$

Já o professor Peter Ritter von Rittinger, em 1867, na Alemanha, definiu que "a área da nova superfície produzida por fragmentação é diretamente proporcional ao trabalho útil consumido" e é expressa da seguinte forma (CHAVES; PERES, 2006):

$$
W=K_{R} *\left(\frac{1}{P}-\frac{1}{F}\right)
$$

Como a aplicação das leis de ambos encontrava diferenças significativas em relação à pratica de algumas aplicações, o debate entre Rittinger e Kick durou muito tempo. Pesquisadores ao redor do mundo se posicionavam de um lado ou de outro, dependendo de onde a incoerência era encontrada.

Os modelos apresentavam incoerências verificadas na prática. Uma constatação importante foi que alguns materiais apresentavam comportamento intermediário entre os dois modelos, além de haver casos em que nenhum dos conceitos se aplicava. Foi em 1952 que Fred C. Bond concluiu, após muitos anos de estudo e visitas a centenas de instalações, que "a energia consumida para reduzir o tamanho de um material é inversamente proporcional à raiz quadrada do mesmo". Bond adotou como tamanho $0 \mathrm{~d}_{80}$. Considerando $\mathrm{P}$ como $\mathrm{o}$ tamanho da alimentação e $\mathrm{F}$ o tamanho do produto, a expressão da Lei de Bond é (CHAVES; PERES, 2006): 


$$
W=10 * W I *\left(\frac{1}{\sqrt{P}}-\frac{1}{\sqrt{F}}\right)
$$

Também foi definido por Bond o WI como sendo o trabalho necessário para reduzir a unidade de peso do material considerado, desde um tamanho inicial teoricamente infinito até um $\mathrm{P}_{80}$ de $100 \mu \mathrm{m}$ (KELLY; SPOTTISWOOD, 1982; FIGUEIRA; ALMEIDA; DA LUZ, 2004; CHAVES; PERES, 2006).

Por mostrar grande adequação à realidade industrial, a aplicação da equação de Bond então se difundiu e a determinação experimental do WI é hoje uma prática generalizada (CHAVES; PERES, 2006). Para esta determinação utiliza-se um moinho e um ensaio padrão (WEISS, 1985). Por este método, foram testados diversos materiais e alguns valores típicos são mostrados na tabela 2.1 .

Tabela 2.1 - Índices de trabalho típicos de diversos materiais, em kWh/st (adaptado de KELLY; SPOTTISWOOD, 1982).

\begin{tabular}{|l|c|c|c|c|}
\hline \multirow{2}{*}{\multicolumn{1}{|c|}{ Material }} & \multicolumn{2}{c|}{ Moinho de Barras } & \multicolumn{2}{c|}{ Moinho de Bolas } \\
\cline { 2 - 5 } & Médio & Intervalo & Médio & Intervalo \\
\hline Alumina & 12,2 & $9-17$ & 17,9 & $7-34$ \\
\hline Argila & 12,5 & $6-18$ & 10,8 & $4-23$ \\
\hline Argila calcinada & 7,0 & $3-13$ & 19,6 & $15-26$ \\
\hline Calcário & 13,7 & $7-50$ & 9,9 & $4-36$ \\
\hline Calcário calcinado & - & - & 11,0 & $6-18$ \\
\hline Carvão & 9,8 & $8-12$ & 15,4 & $13-18$ \\
\hline Clínquer & 12,1 & $8-15$ & 13,6 & $7-77$ \\
\hline Escória de alto forno & 10,1 & $5-13$ & 18,3 & $12-26$ \\
\hline Ferrocromo & 8,4 & - & 20,4 & $3-77$ \\
\hline Ferro-manganês & 7,6 & $7-8$ & 7,9 & $5-14$ \\
\hline Ferro-silício & 7,1 & $4-11$ & 17,9 & $6-51$ \\
\hline Matte de níquel & 9,8 & $9-11$ & 28,4 & $12-37$ \\
\hline Minério de níquel & 14,9 & $8-22$ & 12,5 & $2-24$ \\
\hline Quartzo & 14,4 & - & 14,4 & $11-21$ \\
\hline
\end{tabular}

Estas três formulações são muito estudadas até hoje, sendo encontradas diversas aplicações distintas a cada uma. Quando uma instalação dista muito do usual, por exemplo, pode haver discrepâncias do modelo de Bond em relação ao real. 
Podem ser aplicados então os modelos de Rittinger ou Kick, de acordo com o gráfico mostrado na figura 2.2.

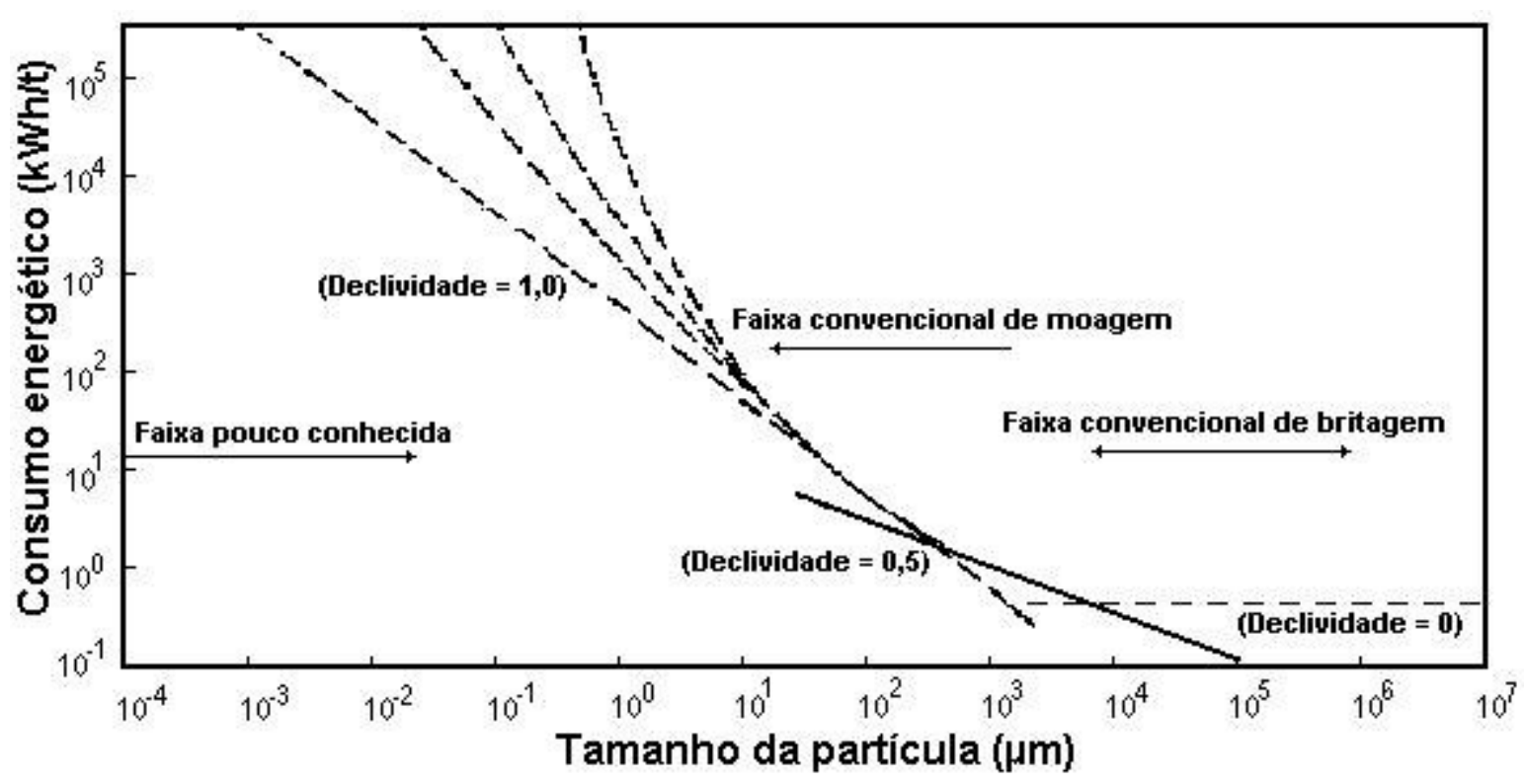

Figura 2.2 - Aplicações dos modelos de energia de quebra (adaptado de FIGUEIRA; ALMEIDA; DA LUZ, 2004).

O gráfico acima expressa a energia de fragmentação em função da característica granulométrica do produto em questão e mostra que as três leis seriam aplicáveis em faixas de tamanho diversas, ainda que a Lei de Bond seja aplicável à faixa de tamanho mais comum em operações industriais de moagem. Entretanto, a Lei de Bond pode levar a grandes discrepâncias em relação à realidade quando as condições de operação são muito distintas das usuais e - dada sua natureza empírica -, quando se afasta muito das condições ensaiadas. Além de Rowland, o próprio Bond procurou corrigir algumas dessas discrepâncias ao introduzir fatores de correção (KELLY; SPOTTISWOOD, 1982).

De acordo com FIGUEIRA; ALMEIDA; DA LUZ (2004), "o problema mais sério da aplicação da Lei de Bond é não considerar o WI como função das variáveis de processo". Atualmente, estão em desenvolvimento técnicas de definição dos resultados da cominuição em função dos mecanismos de aplicação dos esforços 
às partículas (NAPIER-MUNN et al., 2005), as quais poderão, eventualmente, resolver esse problema.

\subsubsection{BRITAGEM}

Segundo FIGUEIRA; ALMEIDA; DA LUZ (2004), britagem é o conjunto de operações de cominuição que "objetiva a fragmentação de blocos de minérios vindos da mina, levando-os a granulometrias compatíveis para utilização direta ou para posterior processamento". Pode ser subdividida em diversos estágios e operar a seco ou a úmido. O principal evento físico de cominuição nesta etapa é a compressão, que ocorre apenas um número limitado de vezes enquanto o material passa através do equipamento, até que o tamanho final seja atingido portanto, a relação de redução é normalmente baixa (CHAVES; PERES, 2006).

Circuitos de britagem normalmente são dimensionados com base nas características do material (composição química e mineralógica, densidade, granulometria, umidade, abrasividade, corrosividade, resistência à compressão, forma das partículas, etc.), do processo (vazão, relação de redução e históricos operacionais), do equipamento (tipo, limitações mecânicas, forma de alimentação, disponibilidade, etc.) e ambientais (operação abrigado, a céu aberto ou em subterrâneo). Britadores podem ser de mandíbulas de um ou dois eixos, giratórios, cônicos, de rolos únicos ou duplos (lisos ou dentados), tipo sizer, autógenos e impactores de eixo horizontal ou vertical (KELLY; SPOTTISWOOD, 1982; CHAVES; PERES, 2006).

Para a britagem de escórias em geral são utilizados britadores de mandíbulas, cônicos, de rolos únicos e de impacto. Um dos motivos principais é manter uma baixa relação de redução, de forma a minimizar a geração de finos e maximizar a liberação (PARKER; LOVEDAY, 1996). À exceção dos cônicos, todos os equipamentos citados são utilizados para recuperar metal de escórias de ferroníquel e terão seu funcionamento descrito nesta revisão. 
Britadores de mandíbulas podem ser de um eixo (Dodge) ou dois (Blake), sendo que sua utilização é condicionada à abrasividade do material, dentre outros fatores. A figura 2.3 mostra os dois equipamentos.
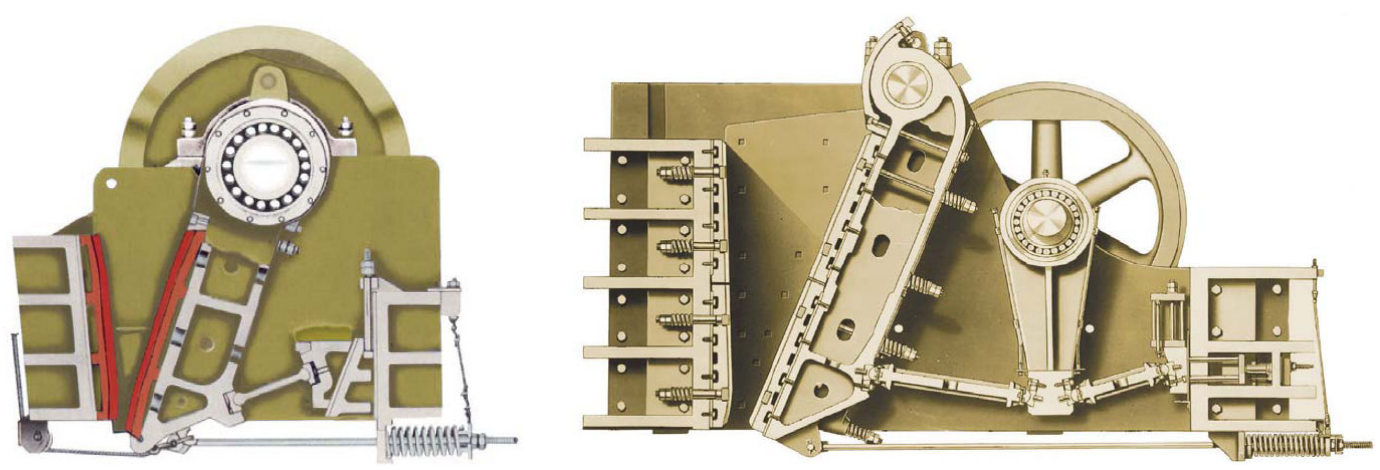

Figura 2.3 - Britador Dodge (esquerda) e Blake (direita) (METSO, 2005).

No caso do Dodge, o movimento circular da mandíbula móvel, provocado pelo eixo, resulta em uma componente vertical da mesma em relação à mandíbula fixa. Quando opera com materiais abrasivos, este movimento eleva sobremaneira o desgaste. Este fenômeno não ocorre no britador Blake, pois o movimento é retilíneo (KELLY; SPOTTISWOOD, 1982; CHAVES; PERES, 2006).

Britadores de rolo único possuem uma configuração interna similar à da figura 2.4.

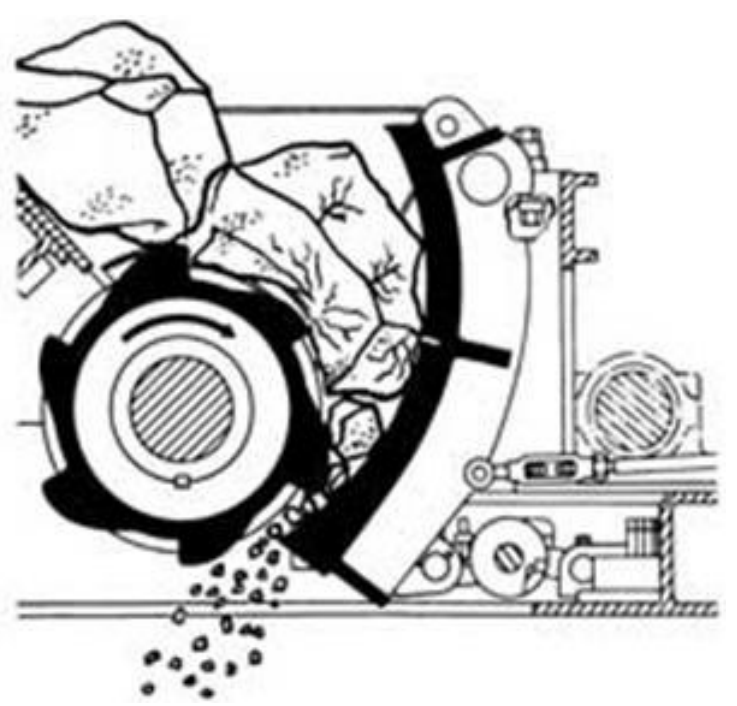

Figura 2.4 - Britador de rolo único (catálogo da PCC). 
O rolo gira a rotações altas (acima de $500 \mathrm{rpm}$ ) e prensa o material contra a parede com os dentes e a seguir o cisalha , o que provoca a ruptura do bloco. De acordo com PENNSYLVANIA CRUSHER (2006), o material deve ser "um pouco friável e possuir um conteúdo de sílica relativamente baixo".

Assim como o britador de rolo único, o britador de impacto possui um eixo e um rotor, o qual leva barras de impacto presas a ele. O material sofre o impacto primário ao chocar-se contra estas barras e é atirado contra as paredes da máquina, onde sofre o impacto secundário. O equipamento possui o corte transversal indicado na figura 2.5 .

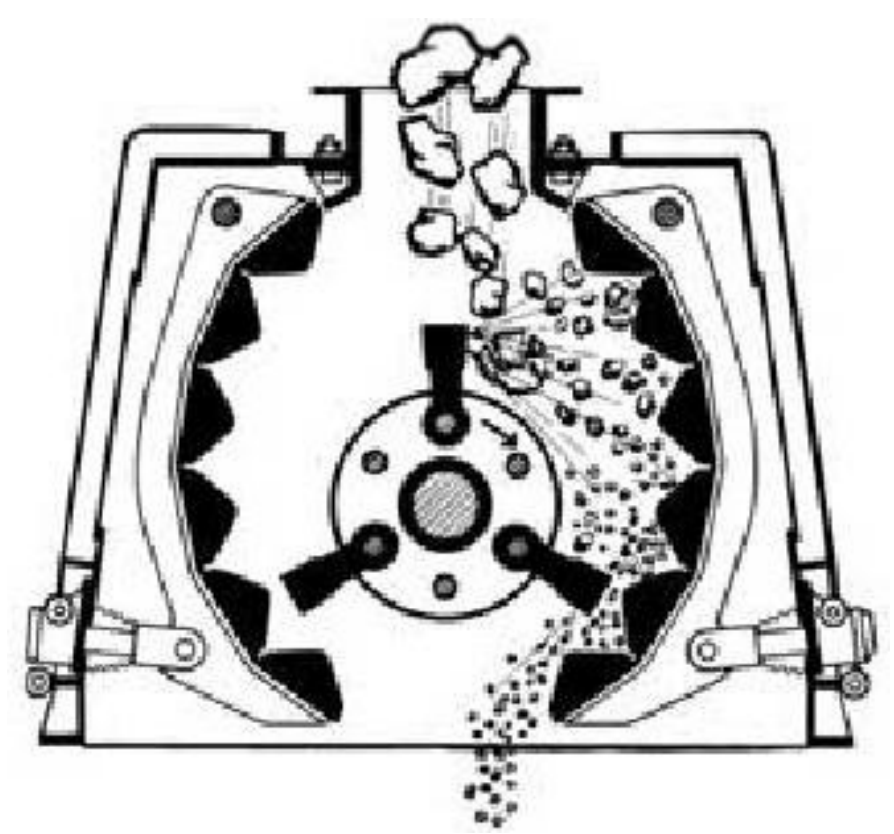

Figura 2.5 - Britador de martelos (catálogo da PCC).

Estes equipamentos possuem vantagens e desvantagens, que serão debatidas nos capítulos 4 e 5. 


\subsubsection{MOAGEM}

Segundo CHAVES; PERES (2006), a moagem é a operação de cominuição realizada "na faixa de tamanhos abaixo de $3 / 4$ " e é efetuada mediante os mecanismos de arredondamento das partículas, quebra de pontas e abrasão". É uma operação custosa: cerca de $3 \%$ da energia mundial é utilizada na cominuição de minérios e quase a totalidade deste valor é representada pela moagem (FIGUEIRA; ALMEIDA; DA LUZ, 2004).

Essencialmente, o dimensionamento e a seleção de um equipamento para moagem envolvem os seguintes fatores:

- características do material (dureza, abrasividade, WI, densidade, distribuição granulométrica e grau de liberação);

- características do processo (vazão de alimentação, processamento a seco/a úmido, grau de enchimento, velocidade de rotação, porcentagem de sólidos e carga circulante);

- características do produto desejado (distribuição granulométrica, etc.);

- tipo do equipamento desejado (moinhos pendulares, tubulares, semiautógenos, de discos, vibratórios, HPGR, etc.);

- tipos de revestimento (elevador, onda simples, etc.);

- tipo de descarga (periférica central, por overflow, por diafragma, etc.);

- tipos de corpos moedores (barras, bolas, seixos, martelos, etc.).

Os três últimos itens desta lista referem-se apenas aos moinhos cilíndricos de carga cadente, que serão abordados neste trabalho.

A experiência industrial demonstra que uma moagem finamente ajustada é determinante para os custos operacionais e para a operação adequada da unidade de concentração ulterior.

Moinhos cilíndricos são constituídos essencialmente de uma carcaça de aço cilíndrica, revestida internamente com placas de borracha ou aço e contendo 
corpos moedores, água (geralmente) e o material a ser moído. No interior de um moinho cilíndrico, a elevação dos corpos moedores (e sua conseqüente queda sobre o material) é controlada pela velocidade de rotação do equipamento. Este dado é normalmente apresentado como uma proporção da velocidade crítica de rotação do mesmo, cujo valor é dado por:

$$
v_{c s}=\frac{42,305}{\sqrt{D}}
$$

De acordo com FIGUEIRA; ALMEIDA; DA LUZ (2004), a velocidade crítica é aquela na qual "a bola fica presa à carcaça pela ação da força centrífuga, durante a volta completa do cilindro". Nessas condições, o corpo moedor não realiza trabalho e, portanto, não mói o material. Por esta razão, utiliza-se apenas uma fração da velocidade (comumente 65-75\%) (CHAVES; PERES, 2006).

Por outro lado, se o moinho está muito cheio, o corpo moedor não possui espaço suficiente para acompanhar o movimento da carcaça de maneira solidária e "cai" de alturas menores. O fator de enchimento é dado por:

$$
F_{f}=113-126 * \frac{h_{c}}{D}
$$

Combinando o enchimento do moinho com sua velocidade de rotação, estabelecem-se dois regimes operacionais distintos (KELLY; SPOTTISWOOD, 1982; FIGUEIRA; ALMEIDA; DA LUZ, 2004):

- operação em cascata: a fragmentação por abrasão e atrito é privilegiada. As bolas não caem de altura suficiente para realizar fragmentação por impacto e acabam por rolar umas sobre as outras (figura 2.6 A). Com bolas menores e maiores enchimentos, ocorre intensa geração de finos;

- operação em catarata: a fragmentação por impacto é privilegiada, pois a altura de queda do corpo moedor sobre o material é suficiente para maximizar este efeito (figura $2.6 \mathrm{~B}$ ). Bolas maiores, enchimento menor, revestimento adequado e velocidade maior contribuem para este efeito, possibilitando a fragmentação de material mais grosso. 

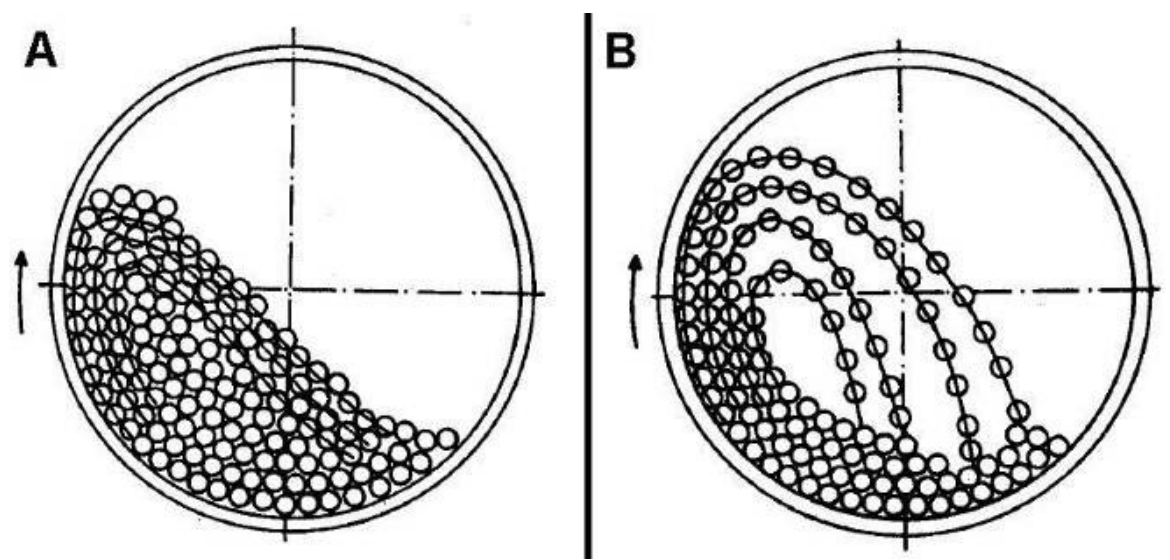

Figura 2.6 - Operação em cascata (A) e catarata (B) (adaptado de KELLY; SPOTTISWOOD, 1982).

Moinhos tubulares podem utilizar barras, bolas ou seixos como corpos moedores. Sendo o comportamento de moinhos de bolas e seixos muito similares, quando descrito o funcionamento de um moinho de bolas, deve-se entender que seixos e cylpebs estão incluídos.

Moinhos de barras são normalmente utilizados para moagem grossa. São capazes de receber materiais com até $50 \mathrm{~mm}$ de tamanho máximo e fornecer um produto tão fino quanto $500 \mu \mathrm{m}$. O comprimento da seção cilíndrica é normalmente 25 a $150 \%$ maior que o diâmetro e é limitado por dois motivos: primeiro, as barras poderiam engaiolar-se; e segundo, porque as barras possuem uma resistência que é grandemente afetada por seu comprimento.

Já os moinhos de bolas são utilizados para moagem fina. Apesar de serem obrigados a receberem alimentações mais finas (cerca de 12,5 mm), os produtos podem ser tão finos quanto $625 \#$. É importante ressaltar que a expressão "moinho de bolas" designa aqueles que possuem "relação comprimento/diâmetro de 1,5 a 1" (FIGUEIRA; ALMEIDA; DA LUZ, 2004). 
Com o tempo, o desgaste dos corpos moedores torna possível observar uma distribuição de diâmetros estável e contínua. Isto é denominado carga de equilíbrio ou carga sazonada. Bond desenvolveu as seguintes tabelas para encontrar esta carga de equilíbrio e facilitar o início de operação do moinho (KELLY; SPOTTISWOOD, 1982; DA LUZ et al., 2004; METSO, 2005):

Tabela 2.2 - Carga inicial de barras, porcentagem em peso retida simples.

\begin{tabular}{|c|c|c|c|c|c|c|}
\hline \multirow{2}{*}{$\mathbf{d}_{\mathbf{r}}$} & \multicolumn{7}{|c|}{ Diâmetros $(\mathbf{m m})$} \\
\cline { 2 - 8 } & $\mathbf{1 2 5}$ & $\mathbf{1 1 5}$ & $\mathbf{1 0 0}$ & $\mathbf{9 0}$ & $\mathbf{7 5}$ & $\mathbf{6 5}$ \\
\hline 125 & 18 & - & - & - & - & - \\
\hline 115 & 22 & 20 & - & - & - & - \\
\hline 100 & 19 & 23 & 20 & - & - & - \\
\hline 90 & 14 & 20 & 27 & 20 & - & - \\
\hline 75 & 11 & 15 & 21 & 33 & 31 & - \\
\hline 65 & 7 & 10 & 15 & 21 & 39 & 34 \\
\hline 50 & 9 & 12 & 17 & 26 & 30 & 66 \\
\hline TOTAL & $\mathbf{1 0 0}$ & $\mathbf{1 0 0}$ & $\mathbf{1 0 0}$ & $\mathbf{1 0 0}$ & $\mathbf{1 0 0}$ & $\mathbf{1 0 0}$ \\
\hline
\end{tabular}

Tabela 2.3 - Carga inicial de bolas, porcentagem em peso retida simples.

\begin{tabular}{|c|c|c|c|c|c|c|c|}
\hline \multirow{2}{*}{$\mathbf{d}_{\mathbf{b}}$} & \multicolumn{7}{|c|}{ Diâmetros (mm) } \\
\cline { 2 - 9 } & $\mathbf{1 1 5}$ & $\mathbf{1 0 0}$ & $\mathbf{9 0}$ & $\mathbf{7 5}$ & $\mathbf{6 5}$ & $\mathbf{5 0}$ & $\mathbf{4 0}$ \\
\hline 115 & 23 & - & - & - & - & - & - \\
\hline 100 & 31 & 23 & - & - & - & - & - \\
\hline 90 & 18 & 34 & 24 & - & - & - & - \\
\hline 75 & 15 & 21 & 38 & 31 & - & - & - \\
\hline 65 & 7 & 12 & 20,5 & 39 & - & - & - \\
\hline 50 & 3,8 & 6,5 & 11,5 & 19 & 43 & 40 & - \\
\hline 40 & 1,7 & 2,5 & 4,5 & 8 & 17 & 45 & 51 \\
\hline 25 & 0,5 & 1 & 1,5 & 3 & 6 & 15 & 49 \\
\hline TOTAL & $\mathbf{1 0 0}$ & $\mathbf{1 0 0}$ & $\mathbf{1 0 0}$ & $\mathbf{1 0 0}$ & $\mathbf{1 0 0}$ & $\mathbf{1 0 0}$ & $\mathbf{1 0 0}$ \\
\hline
\end{tabular}

\subsection{CONCENTRAÇÃO}

O Tratamento de Minérios possui essencialmente três objetivos: concentração de minerais de interesse, eliminação de minerais inadequados para as etapas subseqüentes de processo e redução da massa de material a ser manuseada. (CHAVES et al., 2002). Para realizar os objetivos de concentrar uma determinada espécie mineral, faz-se uso de diferenças em suas propriedades físicas, quais sejam: densidade, suscetibilidade elétrica, suscetibilidade magnética, 
propriedades superficiais, etc. $\mathrm{O}$ emprego de cada uma delas leva a utilizar cada um dos processos de concentração conhecidos: gravítica, magnética, eletrostática ou por flotação (KELLY; SPOTTISWOOD, 1982; SAMPAIO; TAVARES, 2005).

Os métodos utilizados neste trabalho serão revisados a seguir.

\subsubsection{SEPARAÇÃO GRAVÍTICA}

A concentração (ou separação) densitária (ou gravítica) faz uso das diferenças de peso específico, massa, tamanho e forma das partículas para separá-las. Este processo é realizado com o auxílio da gravidade e/ou forças centrífugas. Seu uso é registrado desde a Grécia antiga, tendo seu ápice na segunda metade do século XIX. Possui diversas vantagens em relação a outros processos de concentração (KELLY; SPOTTISWOOD, 1982; LINS, 2004; SAMPAIO; TAVARES, 2005):

- Alta capacidade de processamento, aliada a baixos custos de implantação e operacionais;

- É menos influenciada pela qualidade da água que a flotação ou a lixiviação;

- Ausência de limitação de tamanho máximo de partícula para processamento;

- Ausência da necessidade de reagentes.

Pode-se classificar os equipamentos industriais em quatro grupos (SAMPAIO; TAVARES, 2005):

- de meio denso: vaso de Tromp, tambor, roda Teska, separador Drewboy, Dyna Whirpool, ciclone de meio denso, etc. Serão abordados posteriormente nesta revisão teórica;

- de lâmina d'água: calhas, espirais, cone Reichert, mesas vibratórias (ou oscilatórias), etc.;

- centrífugos: separador Knelson, separador Falcon, multi-gravity separator (MGS), etc.; 
- jigues: Pan American, Yuba, etc.

A operação mais simples pode ser observada a partir do trabalho realizado pelo garimpeiro. Este profissional emprega o conhecimento empírico de separação por métodos gravíticos a partir do uso da bateia, uma vasilha cônica, rasa, de madeira ou chapa de aço. Coloca-se o minério a ser bateado sobre ela, junto com água. Então, de acordo com CHAVES (s/d), o equipamento é operado da seguinte maneira:

[O garimpeiro] inicia um movimento giratório com as mãos, obrigando a polpa que está sobre a bateia a girar sobre ela. As partículas adquirem um movimento circular, as mais grosseiras rolam sobre a bateia, as mais leves são arrastadas pela água e as mais pesadas afundam. Neste movimento, as partículas mais pesadas acabam se dirigindo para o fundo da bateia e daí escorregando para o ápice do cone, onde ficam retidas.

De tempos em tempos, o garimpeiro inclina a bateia e derrama parte da polpa contida em seu interior, que contém partículas leves. As partículas pesadas permanecem no interior do equipamento. A água é reposta e novo procedimento de agitação manual é realizado. Isto é feito até que apenas uma pequena quantidade de material pesado no centro da bateia.

Observa-se que o uso adequado da bateia requer experiência do operador (no caso, o garimpeiro). No caso de equipamentos industriais, buscou-se conhecer melhor os mecanismos físicos que regem a separação densitária: a aceleração diferencial, a sedimentação retardada, a velocidade diferencial em escoamento laminar, a consolidação intersticial e a presença de forças cisalhantes, todos ilustrados na figura 2.7. 


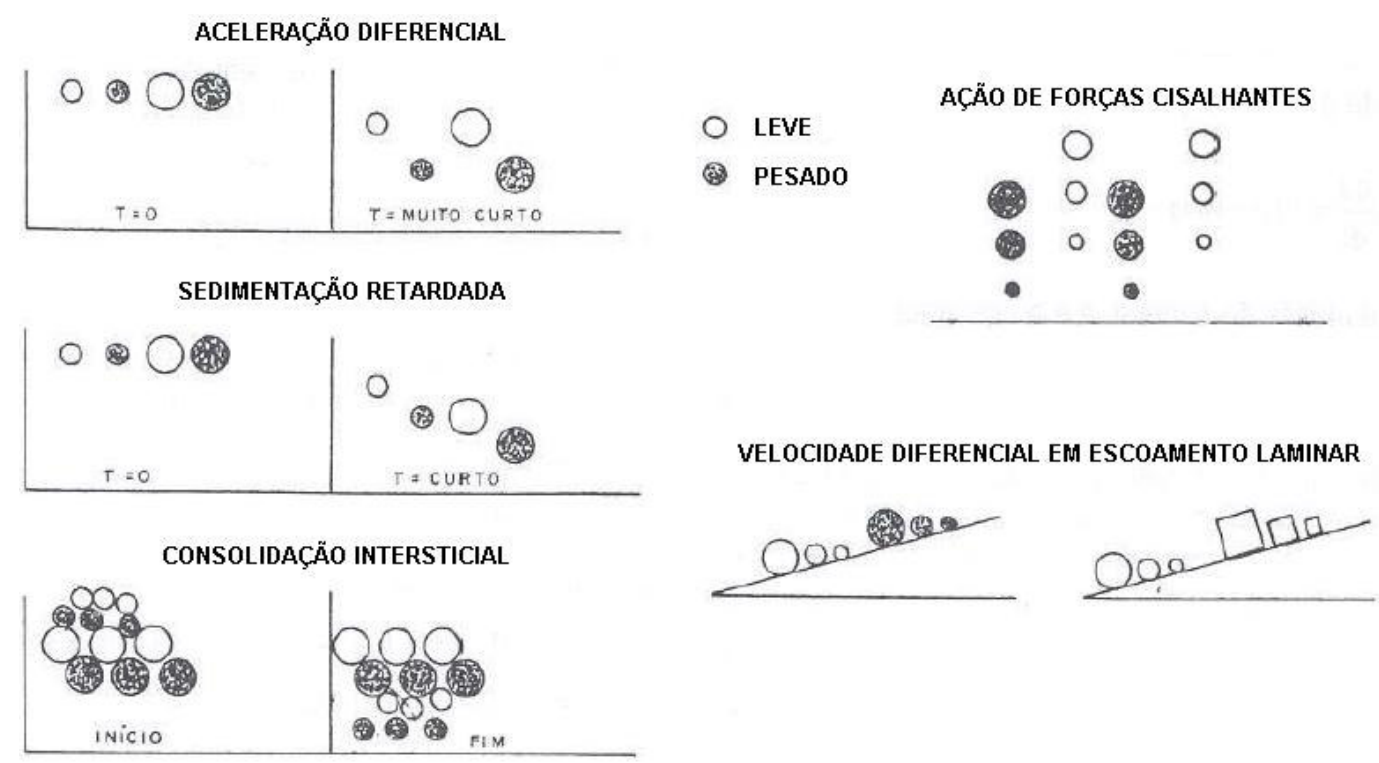

Figura 2.7 - Mecanismos de separação gravítica (adaptado de LINS, 2004).

O escoamento laminar é observado em velocidades baixas. Neste caso, observase a formação de lâminas superpostas do fluido, que compõem um perfil de velocidades parabólico, sendo nula no contato com a calha ou superfície, máximo no interior do fluido e menor na superfície de escoamento (BENNETT; MYERS, 1984). O comportamento de uma partícula num escoamento nessas condições é ilustrado na figura 2.8 .
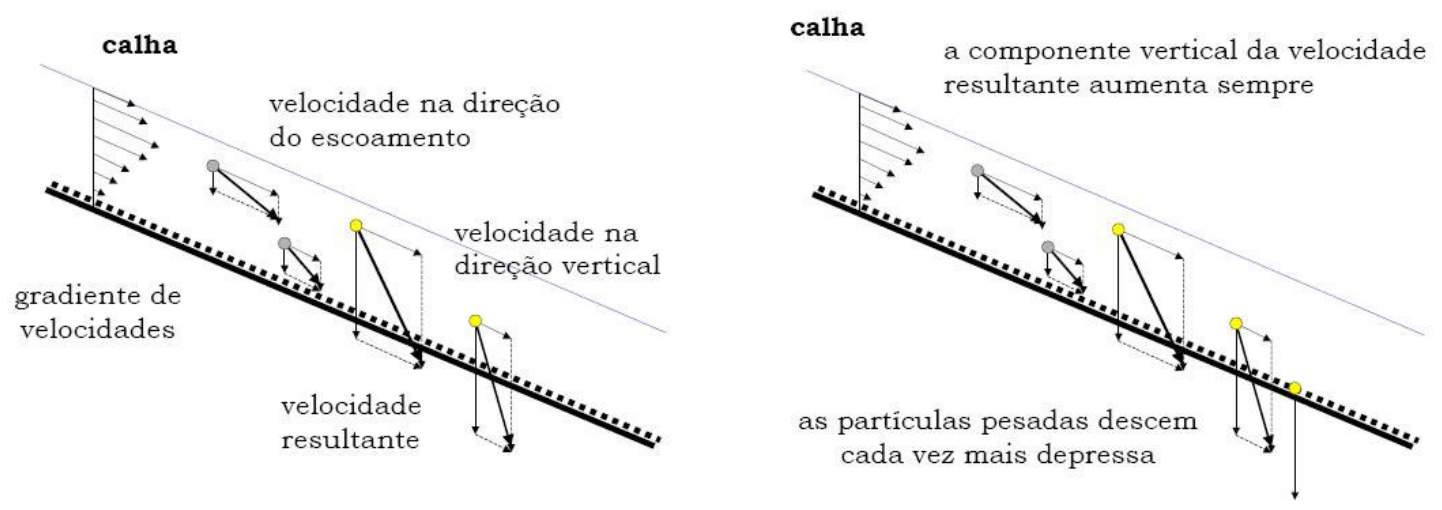

Figura 2.8 - Comportamento de uma partícula em escoamento laminar (apud CHAVES, s/d).

A velocidade da partícula é composta de duas parcelas: uma, na direção do escoamento, que depende da posição da mesma ao longo do perfil de 
velocidades; e outra, na vertical, função do peso de cada partícula. A primeira componente independe do peso da partícula, "pois a massa do fluido é infinita em relação à da partícula e Ihe impõe a sua velocidade" (CHAVES, s/d). Conforme a partícula afunda, devido ao percurso realizado ao longo do gradiente, a primeira componente diminui. Observa-se finalmente que as partículas pesadas não somente afundam mais depressa que as leves, mas também cada vez mais rapidamente.

Quando a partícula atinge o fundo, isto é, a camada limite, a velocidade do escoamento se anula. Dever-se-ia esperar que a partícula também permanecesse estacionária. Entretanto, como a superfície da camada limite possui espessura infinitesimalmente pequena e a partícula não, ela rola sobre o fundo. Os equipamentos industriais aproveitam-se desse fenômeno, fazendo com que as partículas percorram o fundo numa camada dita "individualizada" ou sejam retidas por superfícies rugosas ou riffles. Esse e outros mecanismos são descritos nos equipamentos utilizados neste trabalho, as mesas e as calhas.

Uma maneira encontrada para medir a possibilidade da concentração gravítica é o critério de concentração. Como desconsidera o fator de forma, é uma aproximação e é calculado da seguinte maneira (TAGGART et al., 1945):

$$
C C=\left(\frac{\rho_{2}-1}{\rho_{1}-1}\right)
$$

Para o cálculo, considera-se 2 o mineral pesado e 10 mineral leve, além de 0 fluido ser a água. LINS (2004) e CHAVES (s/d) relatam a seguinte interpretação para diferentes valores do critério de concentração:

Tabela 2.4 - Critério de concentração e comportamento do processo.

\begin{tabular}{|c|l|}
\hline Valor de CC & \multicolumn{1}{|c|}{ Significado } \\
\hline$>2,50$ & Separação eficiente até $0,074 \mathrm{~mm}(200 \#)$ \\
\hline $1,75-2,50$ & Separação eficiente até $0,147 \mathrm{~mm}(150 \#)$ \\
\hline $1,50-1,75$ & Separação possível até $1,4 \mathrm{~mm}$ (difícil) \\
\hline $1,20-1,70$ & Separação possível até $6,0 \mathrm{~mm}$ (difícil) \\
\hline
\end{tabular}


Cabe ressaltar que a tabela 2.4 foi desenvolvida considerando equipamentos que operam apenas sob ação da gravidade. O uso da força centrífuga possibilita de uma separação mais eficiente de materiais finos e superfinos (KELLY; SPOTTISWOOD, 1982; CHAVES, s/d).

Entretanto, este cálculo ainda desconsidera o efeito de forma das partículas. Para isso, é necessário entender o conceito de fator de sedimentação, que nada mais é que a razão entre a velocidade terminal da partícula em questão e de uma esfera do mesmo material. Calculando os fatores de sedimentação para as espécies pesada e leve e dividindo uma pela outra, chega-se ao fator de razão de forma (FRF), proposto por BURT apud LINS (2004) como correção à eq. (6):

$$
C C=\left(\frac{\rho_{2}-1}{\rho_{1}-1}\right) * F R F
$$

Entretanto, é possível avaliar a facilidade de separação por métodos gravíticos apenas através da eq. (6).

Os equipamentos de concentração gravítica podem ser: calhas simples ou estranguladas, cones Reichert, espirais de Humphreys, mesas planas ou inclinadas, jigues, ciclones autógenos, DWP, concentradores centrífugos, etc. Neste trabalho, serão vistos apenas a mesa vibratória (ou oscilatória) e o jigue.

A mesa vibratória evoluiu a partir da mesa estática. Consiste de uma placa inclinada, com ressaltos longitudinais no sentido do fluxo material, que possuem o objetivo de proteger o arraste dos finos pesados pelos grossos leves (LINS, 2004). Recebe água pela extremidade superior, que arrasta as partículas na direção da extremidade inferior e as pesadas se depositam atrás dos riffles, enquanto as leves passam por sobre eles (CHAVES, s/d). O movimento oscilatório é realizado perpendicularmente à direção do fluxo d'água, com velocidade de retorno maior que a de avanço, de forma a fazer as partículas andarem nessa direção (KELLY; SPOTTISWOOD, 1982; CHAVES, s/d). As 
partículas pesadas são então empurradas atrás dos rifles, até atingir a extremidade da mesa, onde ocorre a separação final mediante o uso de desviadores para os diferentes fluxos.

A figura 2.9 ilustra os fenômenos que ocorrem na mesa.
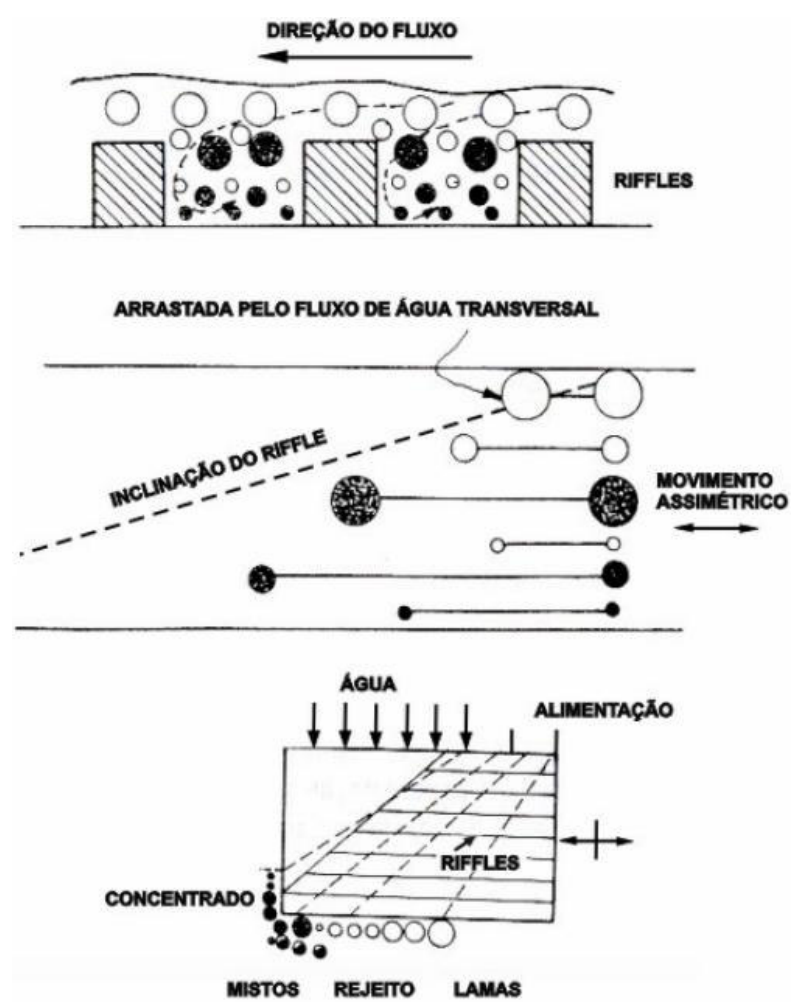

Figura 2.9 - Funcionamento de uma mesa vibratória (LINS, 2004).

Há duas regiões principais: a lisa e a que possui riffles. Esta última recebe a alimentação de forma transversal e o comportamento da polpa recebe influência do movimento oscilatório da mesa. Nas regiões entre os riffles ocorre sedimentação retardada e consolidação intersticial. A água de lavagem arrasta as camadas superiores e os riffles têm sua altura reduzida ao longo do comprimento da mesa, de forma que as partículas finas e pesadas sejam concentradas. $\mathrm{Na}$ parte lisa da mesa, ocorre a concentração final, conforme descreve LINS (2004):

A concentração final tem lugar na região lisa da mesa, onde a camada de material apresenta-se mais fina (algumas partículas de espessura). A resultante do movimento assimétrico na direção dos riffles e da velocidade diferencial em escoamento laminar, perpendicularmente, é o espalhamento dos minerais (...). 
De acordo com CHAVES (s/d), na descarga, "o posicionamento de septos para separar os fluxos (...) resulta em produtos pesados, leves, intermediários e lamas, com boa qualidade de separação".

Entretanto, é um equipamento de baixa capacidade, normalmente na faixa 50-300 $(\mathrm{kg} / \mathrm{h}) / \mathrm{m}^{2}$, e portanto proporcional à área de separação. Isto resulta na existência de equipamentos grandes, incorrendo no aumento dos custos de implantação (MILLS, 1978; LINS, 2004; SAMPAIO; TAVARES, 2005). É comum a aplicação em carvões e minérios aluvionares (KELLY; SPOTTISWOOD, 1982). É considerado o equipamento mais eficiente para tratamento densitário de finos. Suas características geométricas são:

- comprimento: definido em função da recuperação desejada;

- largura: normalmente $1 \mathrm{~m}$, define a capacidade (60 t/h.m largura);

- distância vertical entre as seções: $8 \mathrm{~cm}$, com afastamento regulável normalmente a $2,5 \mathrm{~cm}$;

- inclinação: entre $8^{\circ}$ e $10^{\circ}$.

Como normalmente recebe a descarga da moagem diretamente, trabalha com 60$70 \%$ de sólidos (KELLY; SPOTTISWOOD, 1982). Possui alta razão de concentração e baixo investimento e custo operacional.

As variáveis operacionais são a vazão de sólidos alimentada, a vazão de água, a inclinação da mesa, a freqüência da vibração e o posicionamento dos septos. A combinação criteriosa destas variáveis leva a separações muito precisas, ainda que haja controvérsia quanto a um possível efeito negativo da presença de lamas na alimentação da mesa (CHAVES, s/d).

A mesa Mozley é um conhecido equipamento de laboratório. Costuma oferecer dados suficientes para balizar testes com métodos gravíticos subseqüentes. Ela possui uma bandeja lisa com seção transversal em forma de concha e água é injetada por uma das extremidades e pelas laterais. A alimentação é posicionada, em bateladas, junto à extremidade por onde se adiciona água. Uma vez ligado o 
equipamento, a bandeja oscila em um movimento similar a um arco de circunferência, com linha de simetria coincidente à linha de centro da bandeja. As partículas leves são retiradas pelo movimento oscilatório e pela água de lavagem e são coletadas na extremidade oposta. Uma vez identificado que a fração leve já deixou a mesa, é feita lavagem da bica de descarga e, com o equipamento desligado, retira-se o concentrado com uma pisseta. A figura 2.10 ilustra o equipamento.

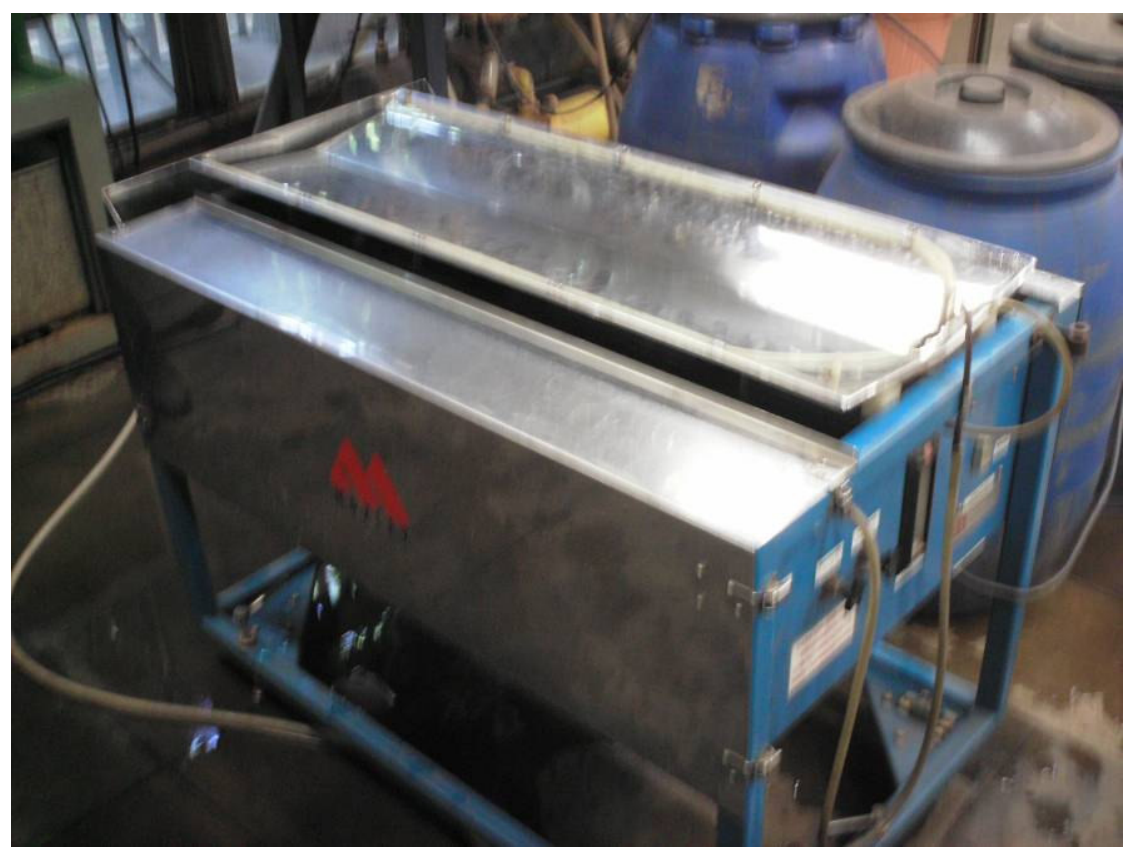

Figura 2.10 - Mesa Mozley.

Jigues são equipamentos de concentração gravítica utilizados há muito pela civilização humana. Registros históricos mostram que já no Antigo Egito era um equipamento conhecido ( $A L I, 2003$; CHAVES, s/d). Na Idade Média, foi muito difundido, principalmente em aplicações com minérios de ouro e cassiterita (AGRICOLA, 1556). Pelo fato de ainda hoje ser utilizada desde 4.000 anos atrás, com os mesmos princípios, tem seu motivo de ser estudada. Seus mecanismos são complexos, devido às variações hidrodinâmicas observadas no equipamento (GAUDIN, 1945). 
Um jigue simples pode ser construído a partir de um cesto perfurado, contendo o material que se deseja separar e sustentando por uma haste, e um tanque de água. Fazem-se imersões e emersões repetidas desse cesto a partir da haste. Após algumas repetições, retira-se o cesto do tanque. Obter-se-á três frações distintas (CHAVES, s/d):

- a superior, que é descartada como rejeito;

- a fração inferior, composta dos minerais pesados, que é o concentrado; e

- a fração intermediária, composta de minerais ainda não separados ou não liberados, que permanece no cesto para novo ciclo de processamento.

A figura 2.11 ilustra a concentração gravítica em um jigue onde, em vez de o cesto oscilar dentro d'água, esta é que imprime ao minério o movimento oscilatório vertical através da tela:

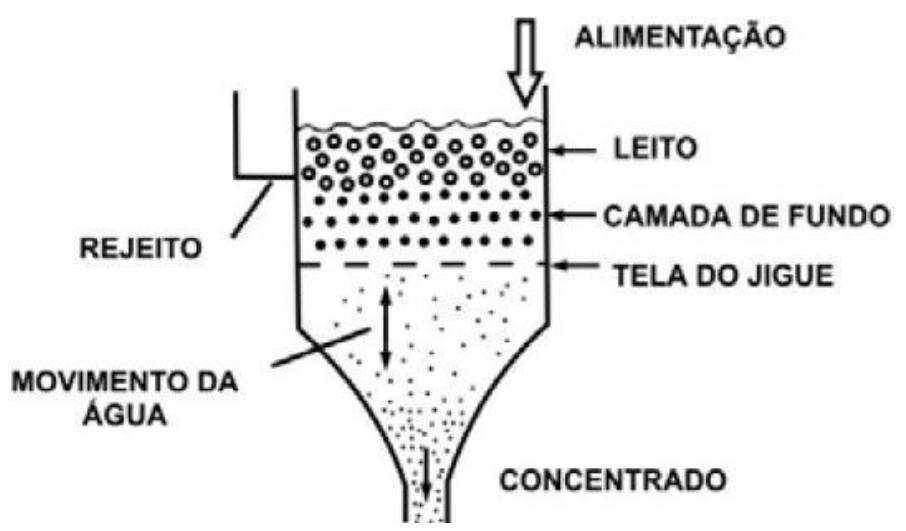

Figura 2.11 - Operação de um jigue (LINS, 2004).

A separação dos minerais é realizada com o auxílio de um leito dilatado por uma corrente pulsante de água (produzido por um diafragma, por exemplo), que estratifica as partículas no leito. Esses fenômenos foram descritos por GAUDIN (1945) com uma abordagem hidrodinâmica, e este sugeriu que a sedimentação retardada (influenciada pela aceleração diferencial) e a consolidação intersticial seriam os mecanismos a influir no processo. Graças aos efeitos de sucção e impulsão do leito de água, pode-se chegar a "uma classificação quase perfeita, segundo a densidade dos minerais" (LINS, 2004). 
Assim descreveram CHAVES (s/d) e SAMPAIO; TAVARES (2005) o funcionamento do jigue. O primeiro mecanismo a ocorrer no processo é a aceleração diferencial. Enquanto a água é injetada, as partículas percorrem o leito ascendentemente, na direção do fluxo. As partículas leves percorrem um trecho maior que as pesadas. Quando o ciclo ascendente cessa e a fase de "sucção" se inicia - sucção entre aspas, pois se deseja que a água esteja estagnada -, as partículas afundam pela ação do seu próprio peso. As leves afundam mais devagar e por um percurso curto. Já as pesadas, rapidamente e por um percurso longo. Após certo número de ciclos, as partículas leves ficam por cima e as pesadas por baixo, distantes entre si.

Entretanto, este fenômeno ocorre sozinho apenas quando as partículas estão isoladas. No caso de um jigue, elas se dispõem na forma de um leito e, portanto, seus movimentos sofrem interferências das partículas vizinhas. Durante a injeção, o leito se expande e as partículas são lançadas para cima - ou seja, até certo ponto, ocorre o que foi descrito no parágrafo anterior. Durante a sedimentação, "o leito começa a se fechar, dificultando o movimento descendente" (CHAVES, s/d). No fim do ciclo, o leito fecha-se totalmente e as partículas grossas, pesadas ou leves, não conseguem mais se mover. Por isso o jigue é um equipamento tão seletivo: partículas grossas e de baixa densidade deveriam afundar, caso o leito não se fechasse, mas as partículas finas conseguem passar por entre as grossas e chegam ao fundo do leito. As partículas finas pesadas afundam mais que as leves e, portanto, são encontradas em um ponto inferior às leves. $O$ arranjo final é similar à figura 2.12 .

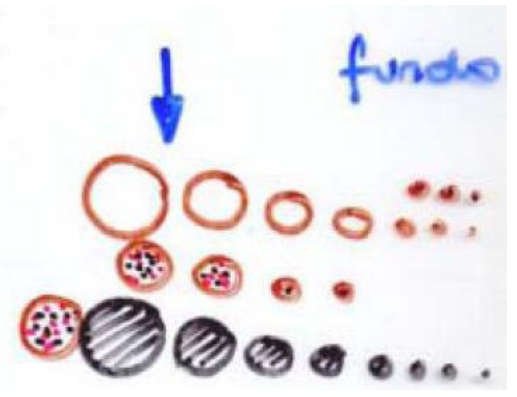

Figura 2.12 - Arranjo final do leito do jigue (CHAVES, s/d). 
É notável a ocorrência de alguma superposição de partículas mistas, mas as leves e as pesadas estão totalmente separadas. Cabe ressaltar que as leves e grosseiras, apesar de possuírem grande massa, não conseguem penetrar no leito fechado. Assim, o jigue é um equipamento eficiente e independe do tamanho das partículas a separar. Baseado nesta observação, TAGGART (1945) define o jigue como "um concentrador mecânico, que efetua a separação de grãos pesados e leves, por meio das diferenças de capacidade de penetração num leito semiestacionário".

De acordo com CHAVES FILHO apud CHAVES (s/d), a relação entre a freqüência e a amplitude da pulsação de um jigue é:

$$
f * a=789,6 \sqrt{\left(d *\left(\rho_{s}-1\right)\right)}
$$

Algumas características particulares do jigue (LINS, 2004; CHAVES, s/d) são:

- divisão em câmaras com regulagem independente;

- ciclos curtos e rápidos de pulsação são melhores para materiais finos: ciclos longos são melhores para grossos;

- o ingresso de água de processo não deve variar: recomendável alimentar a água por gravidade, a partir de um tanque.

O jigue possui limitações quanto ao dispêndio energético e à confiabilidade da operação. De acordo com CHAVES (s/d), o primeiro jigue mecânico foi o Harz, desenvolvido na região mineira do Harz, na Alemanha. Possui um pistão que sobe e desce e, com o movimento, empurra a água através de um crivo, para cima e para baixo. $O$ ciclo do cesto perfurado é realizado, então, mecanicamente.

O ciclo de pressão imposto pela água sobre o leito de minério possui forma senoidal. Percebeu-se que "a sucção violenta da água, que ocorria quando o pistão subia, era prejudicial à seletividade da separação" (CHAVES, s/d). Passouse a injetar água por debaixo do leito durante a sucção. O desenvolvimento posterior foi a substituição do pistão por uma câmara de ar comprimido, com 
descarga controlada. Com ajustes adequados das velocidades de admissão e descarga, descobriu-se uma enorme vantagem para a qualidade da separação. Chamou-se este novo equipamento de jigue Baum (SAMPAIO; TAVARES, 2005).

O jigue moderno para carvão (McNally), em que a separação principal ocorre no leito, é semelhante ao ilustrado na figura 2.13.

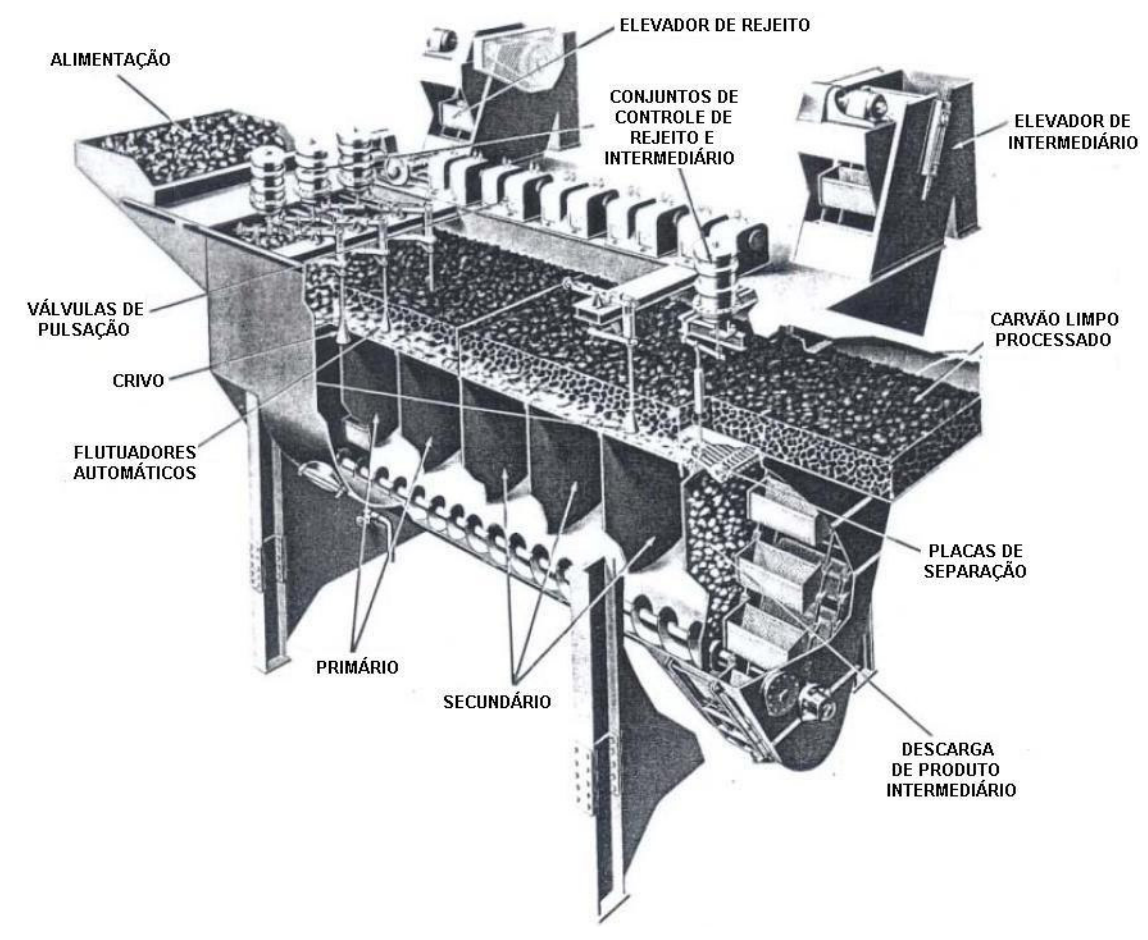

Figura 2.13 - Jigue moderno (adaptado de CHAVES, s/d).

Neste caso são retirados três produtos de densidades diferentes. Os pesados finos atravessam o crivo e são arrastados, no caso da figura, por um transportador helicoidal instalado no fundo do equipamento. Os pesados grossos correm por cima do crivo até a câmara seguinte e são separados dos intermediários pelo septo de corte. O produto intermediário é descarregado pelo fundo da segunda câmara, juntado aos finos e retirado por um elevador de canecas furadas, de forma a permitir a drenagem do produto pesado. 
A posição do septo de separação entre os leitos de afundado e flutuado é fundamental para o funcionamento adequado do equipamento. De acordo com CHAVES (s/d) e SAMPAIO; TEIXEIRA (2005), os fabricantes desenvolveram várias alternativas:

- Jeffrey: uma válvula rotativa com velocidade variável gira, de forma a manter constante a altura da camada de pesados. A altura é determinada pela posição de um flutuador, de densidade igual à de corte, que aciona um dispositivo eletromecânico que controla a velocidade de descarga;

- McNally: um flutuador controla a altura da interface entre o leito de pesados e de leves, e aciona uma fila de martelos que sobem e descem e dão passagem aos pesados. Esses martelos são convenientes para a passagem de partículas maiores ou menores, eventualmente presentes na fração de pesados. A densidade de corte é controlada por um braço de alavanca que sustenta o flutuador;

- NCB (jigue ROSE): usa um sistema de radar (ou ultrassom) para detectar a altura da interface com o leito e controlar a descarga eletronicamente; e

- Batac: o estado-da-arte de projeto de jigues, totalmente automatizado e programável, com válvulas independentes de admissão e descarga de ar, controladas por um programa de computador, que leva em conta a recuperação desejada. Possui também injeção do pulso no centro da câmara e grande sofisticação de projeto. Sua precisão de corte é comparável à dos sistemas de meio denso.

Os jigues são classificados pela maneira como a dilatação do leito é feita (KELLY; SPOTTISWOOD, 1982):

- Tela móvel: a caixa do jigue se move na vertical em relação ao leito d'água (é chamado de jigue Hancock);

- Tela fixa: o concentrado passa através da tela do jigue. Possui subclasses de acordo com o mecanismo que movimenta o leito, como o jigue Denver (que possui um êmbolo de borda selada), o Yuba (diafragma na parede da câmara) e o PanAmerican (diafragma ao lado da câmara). 
O jigue PanAmerican (figura 2.14) é um jigue muito utilizado para materiais pesados, como minérios aluvionares ou de ouro. Geralmente são minérios pobres e cujo processamento resulta em pequenas quantidades de concentrado. Este, por sua vez, é fino e descarregado pelo fundo - portanto, com capacidade limitada de retirar partículas pesadas (CHAVES, s/d).

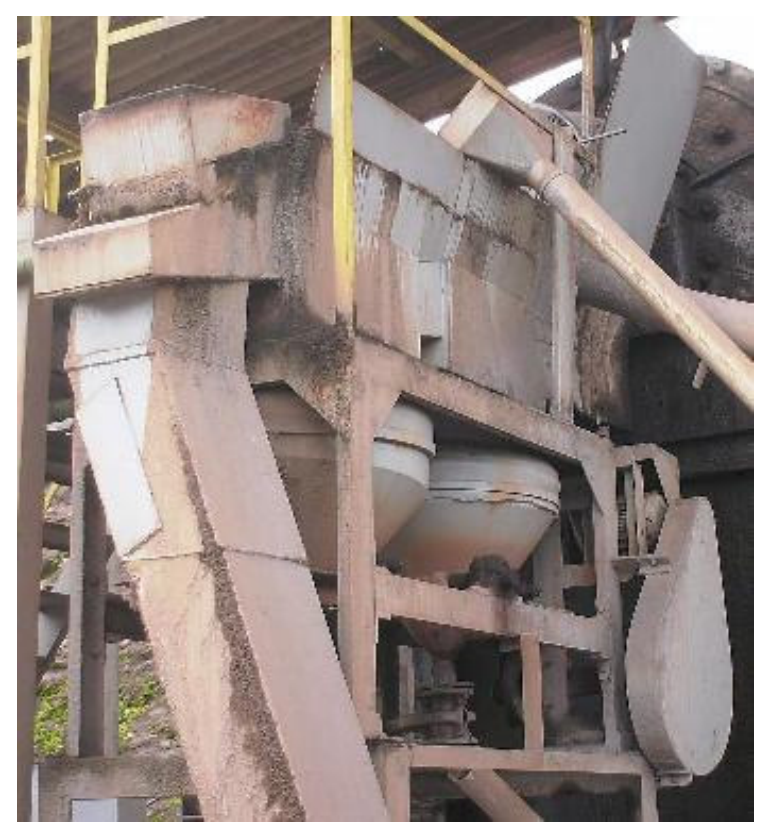

Figura 2.14 - Jigue PanAmerican.

Há outros jigues, como o Denver, O IHC-Cleveland, O trapezoidal (Alvenius), dentre outros. A intenção deste texto, entretanto, não é apresentar um conteúdo totalmente abrangente, contendo todo o universo de jigagem, mas apenas apresentar as informações necessárias ao desenvolvimento deste trabalho.

A eficiência dos equipamentos é influenciada principalmente pela vazão de alimentação, pela granulometria da mesma e pela quantidade de água alimentada (porcentagem de sólidos). A preparação da alimentação é geralmente realizada com escalpe prévio ou deslamagem, de forma a adequar a distribuição granulométrica da mesma, assim como também se pode adicionar água de lavagem sob pressão. 


\subsubsection{SEPARAÇÃO EM MEIO DENSO}

Em 1858, o engenheiro metalurgista Sir Henry Bessemer patenteou o uso de soluções de cloreto de ferro, bário, manganês e cálcio como meios de separação de minerais. Utilizado inicialmente para carvões na Alemanha, o processo não possuía recuperação muito boa, nem fazia separações para densidades acima de 1,35. Esta iniciativa foi acompanhada pelo uso de suspensões de água e areia nos EUA até o início do século XX. Foi então que a Du Pont, em 1917, realizou a primeira aplicação comercial deste processo (BURT, 1984).

O principal problema encontrado até então era que as separações só eram possíveis para densidades baixas. Um desses materiais era o carvão, que apresentava outro desafio: os cloretos presentes provocavam corrosão e custos altos. Passou-se então a utilizar finos de argila, barita, gesso e pirita suspensos em água, o que resolveu os problemas de corrosão, mas não os relativos às densidades altas dos minerais de interesse (KELLY; SPOTTISWOOD, 1982; BURT, 1984).

Para resolver este problema, iniciou-se o uso da galena na preparação dos meios densos (CAMPOS; DA LUZ; CARVALHO, 2004), e posteriormente ferro-silício e magnetita, vantajosos devido à fácil recuperação destes (por separação magnética) e à dificuldade de obtenção da galena (BURT, 1984).

Segundo BURT (1984) e CAMPOS; DA LUZ, CARVALHO (2004), os equipamentos industriais são classificados de acordo com sua aplicação, seja para partículas grosseiras ou finas. Os mais importantes são o separador Tromp, a roda Teska e o tambor de meio denso (partículas grosseiras) e o ciclone de meio denso, o ciclone autógeno e o dyna whirlpool (finas). Em laboratório, também são feitas separações densitárias, e intenciona-se atingir pelo menos um dos seguintes objetivos:

- estudar o grau de liberação dos minerais a serem separados; 
- investigar a viabilidade técnica da concentração gravítica para uma determinada rota de processo;

- determinar parâmetros de controle de processos e ensaios de concentração gravítica;

- avaliar qualitativa e quantitativamente processos de separação gravítica.

Para compreender este texto, faz-se necessário definir os seguintes termos:

- afundado: material cuja densidade é maior que a do meio (chamado de produto pesado na operação industrial);

- flutuado: material cuja densidade é menor que do meio (chamado de produto leve na operação industrial);

- meio: material utilizado para formar o meio denso (FeSi, magnetita, etc.),de forma que o meio denso possua densidade intermediária à dos minerais de interesse e de ganga;

- misto: produto contendo minerais de interesse e minerais de ganga;

- pré-concentrado: produto obtido em momento anterior à liberação total do mineral valioso ou da ganga a ele associada. É um exemplo da aplicação do critério de Taggart, que ensina que se deve retirar a ganga ou o produto final do processo o quanto antes for possível (técnica e economicamente) (TAGGART et al., 1945);

- suspensão: sistema heterogêneo no qual sólidos insolúveis são dispersos e onde as características do meio líquido são mantidas.

As características necessárias para que um meio denso seja utilizado são: baixas viscosidade, corrosividade e toxicidade, facilidade de ajuste de densidade e recuperação posterior e capacidade de formar suspensão ou solução estável, além do baixo custo. Podem ser soluções aquosas de sais inorgânicos $\left(\mathrm{CaCl}_{2}\right.$, $\mathrm{ZnCl}_{2}$, etc.), líquidos orgânicos (restritos a ensaios de laboratório), suspensões de sólidos finamente divididos (FeSi, magnetita, etc.) em água e fluidos paramagnéticos (ferrita dispersa com lignosulfato, cuja densidade varia com a intensidade do campo à qual é submetida) (BURT, 1984; CAMPOS; DA LUZ; CARVALHO, 2004). 
Fundamentalmente, o desempenho de uma operação de meio denso está relacionado às propriedades hidrodinâmicas, granulometria e densidade dos materiais a serem separados e às propriedades reológicas, viscosidade, limite de escoamento, densidade e estabilidade da suspensão, sendo que esta última deverá ser a mais alta possível. Neste caso, estabilidade significa "o inverso da taxa de sedimentação da suspensão", o que demandará menor agitação durante a operação industrial. No limite, a viscosidade tornará a operação impraticável e deve-se buscar um equilíbrio entre essas duas características do meio, demandando que os finos sejam completamente eliminados do processo também porque provocam alterações na densidade da suspensão. Exemplo disso são as vantagens dos líquidos orgânicos em relação às suspensões de sólidos: baixa viscosidade, baixa abrasividade e alta estabilidade, facilitando sua recuperação (KELLY; SPOTTISWOOD, 1982; BURT, 1984; CHAVES, s/d).

Independentemente do fluido, equipamentos de meio denso podem ser estáticos (atuação exclusiva de forças gravitacionais no meio) ou dinâmicos (auxílio de forças centrífugas), de escala industrial ou de laboratório. Nos equipamentos dinâmicos, a principal força atuante é oriunda da aceleração centrífuga, em detrimento da gravidade (BURT, 1984; WILLS, 1988).

Existem quatro classes de suspensões, conforme a tabela 2.5.

Tabela 2.5 - Classes de suspensões (CAMPOS; DA LUZ; CARVALHO, 2004).

\begin{tabular}{|c|l|}
\hline Densidade & \multicolumn{1}{|c|}{ Uso } \\
\hline $1,30-1,90$ & Beneficiamento de carvões \\
\hline $2,70-2,90$ & Pré-concentração de minerais metálicos \\
\hline $2,90-3,60$ & Minérios especiais, diamantes \\
\hline$>3,60$ & Raramente utilizadas \\
\hline
\end{tabular}

No laboratório, as quantidades de amostras são diminutas. Por exemplo, ao peneirar as amostras, pode-se realizar os ensaios em meio denso com o auxílio de um béquer, de um funil de separação ou de uma centrífuga, conforme a fração granulométrica ensaiada. No caso do béquer, o material é despejado junto a uma 
quantidade de líquido denso em um béquer. É realizada agitação vigorosa e aguarda-se que parte do material flutue e parte desça ao fundo. Torna-se a agitar os produtos flutuado e afundado, para libertar eventuais partículas arrastadas mecanicamente. Os materiais são extraídos manualmente com técnicas de laboratório (filtragem, etc.).

Além do béquer e da centrífuga, existe também o ensaio de afunda-flutua, realizado com o cone de líquido denso, da Denver, mostrado na figura 2.15.

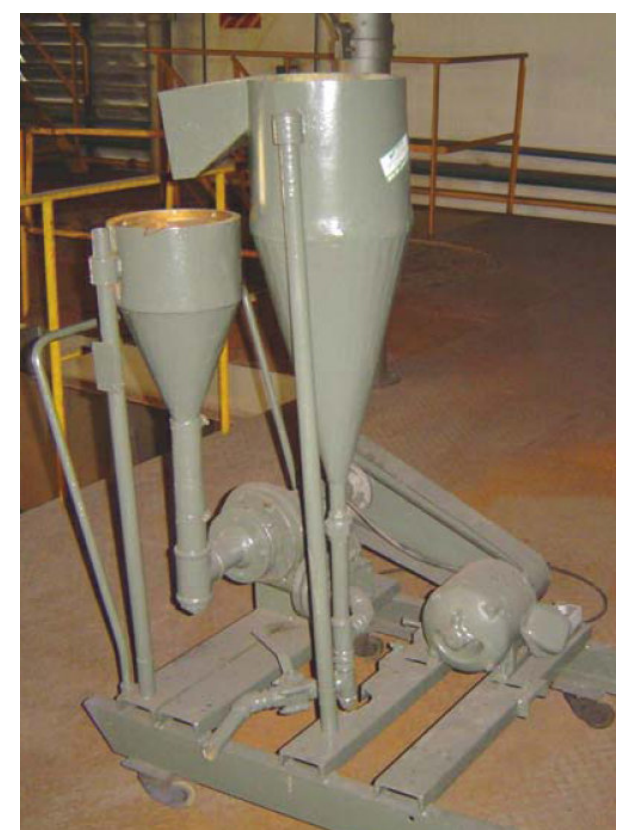

Figura 2.15 - Equipamento de ensaio afunda-flutua.

O equipamento consiste de dois compartimentos cilindro-cônicos que se comunicam por meio de uma calha. Estes dois compartimentos possuem peneiras nos fundos das partes cilíndricas, que permitem a circulação do líquido denso, por bombeamento, no sentido do compartimento maior para o menor.

Normalmente, realizam-se ensaios nesse equipamento para amostras maiores, tanto em granulometria quanto em massa, impossíveis de serem realizados com líquidos orgânicos. Os ensaios são realizados em bateladas, com a alimentação previamente preparada. A alimentação é introduzida no compartimento maior. 
Neste compartimento, o material flutuado passa por transbordo e por meio de uma calha para o compartimento menor, onde fica retido em uma peneira. $O$ material afundado, mais denso, permanece no fundo do primeiro compartimento, procedendo assim à separação.

\subsubsection{SEPARAÇÃO MAGNÉTICA}

Enquanto métodos gravíticos fazem uso da diferença entre densidades das partículas, a separação magnética se utiliza da resposta das espécies mineralógicas a um campo magnético, que é chamada de susceptibilidade magnética. As espécies fortemente atraídas pelo campo são chamadas ferromagnéticas (como a magnetita). Já as espécies que não são atraídas tão intensamente pelo campo são chamadas de paramagnéticas (como a hematita). As que são repelidas pelo campo (i.e. não atraídas) são chamadas diamagnéticas (KELLY; SPOTTISWOOD, 1982). Como aplicação industrial, "pode ser empregada (...) no beneficiamento de minério e na remoção de sucata" (SAMPAIO; DA LUZ, 2004), em tarefas como concentração de minérios de ferro, eliminação de impurezas magnéticas (como no beneficiamento de caulim), retirada de metais de frações não metálicas (com o objetivo de recuperá-las no processo) e no beneficiamento de urânio.

A tabela 2.6 mostra alguns exemplos de minerais e sua reação ao campo magnético (KELLY; SPOTTISWOOD, 1982; SAMPAIO; DA LUZ, 2004).

Tabela 2.6 - Susceptibilidade magnética de alguns minerais.

\begin{tabular}{|c|c|c|}
\hline Ferromagnéticos & Paramagnéticos & Diamagnéticos \\
\hline Magnetita $\left(\mathrm{Fe}_{3} \mathrm{O}_{4}\right)$ & Hematita $\left(\mathrm{Fe}_{2} \mathrm{O}_{3}\right)$ & Quartzo $\left(\mathrm{SiO}_{2}\right)$ \\
& & Magnesita $(\mathrm{MgO})$ \\
& & Calcita $\left(\mathrm{CaCO}_{3}\right)$ \\
& & Fluorita $\left(\mathrm{CaF}_{2}\right)$ \\
\hline
\end{tabular}

Os equipamentos que realizam separação magnética o fazem por via seca ou úmida, e são subdivididos de acordo com a intensidade do campo aplicado (baixa 
ou alta intensidade) e da geometria dos elementos que efetuam a separação (tambores, rolos, correias cruzadas, carrossel, etc.) (KELLY; SPOTTISWOOD, 1982; SAMPAIO; DA LUZ, 2004).

O método a seco é usado, em geral, para granulometria grossa e o a úmido para aquelas mais finas. Recentemente têm-se verificado grandes avanços em ambos os métodos, assim como a utilização de bobinas construídas com materiais supercondutores e de imãs permanentes construídos com novos materiais (ímãs de "terras raras"), que abriu um novo horizonte na área de processamento de minérios.

Ao descrever um campo magnético, é comum a referência à densidade de fluxo magnético e à intensidade de campo, representadas respectivamente por $\mathrm{B}$ e $\mathrm{H}$. Elas se relacionam da seguinte maneira (SERWAY, 2004):

$$
\vec{B}=\mu \vec{H}
$$

Quando uma partícula fracamente magnética é inserida no meio, em uma dada região do espaço, o fluxo B é acrescido de uma parcela denominada indução magnética do material, que aparece no interior da partícula (SAMPAIO; DA LUZ, 2004):

$$
\vec{B}=\vec{H}+\vec{\Psi}
$$

Pode-se relacionar $\Psi$ à magnetização do material, de acordo com SERWAY (2004), pela equação abaixo:

$$
\vec{\Psi}=4 \pi \vec{J}
$$

SERWAY (2004) denomina susceptibilidade magnética $(k)$ a relação entre $\mathrm{J}$ e H. Materiais paramagnéticos possuem $\mathrm{k}$ de baixo valor, normalmente inferiores a 0,001 . No caso de materiais diamagnéticos, $k$ é negativo e de módulo inferior a 0,00001 . Materiais ferromagnéticos possuem $k$ variável com o campo de magnetização e a natureza e o manuseio da amostra. Por esse motivo, materiais ferromagnéticos são referenciados de acordo com sua permeabilidade magnética (SAMPAIO; DA LUZ, 2004). 
Para partículas minerais, pode-se considerar o experimento ilustrado na figura 2.16. Seja um campo magnético gerado por um solenóide. À direita, vê-se um gráfico indicando a variação do campo ao longo do eixo do solenóide. Quando amostras de materiais diamagnéticos, paramagnéticos e ferromagnéticos são colocados na posição indicada na figura, observa-se, ao variar a corrente no solenóide, uma variação na indicação do dinamômetro. Verifica-se que o dinamômetro registra valores mais altos nas extremidades de espira, onde há maior gradiente de campo - no centro, o gradiente é nulo (LAWVER; HOPSTOCK, 1974).

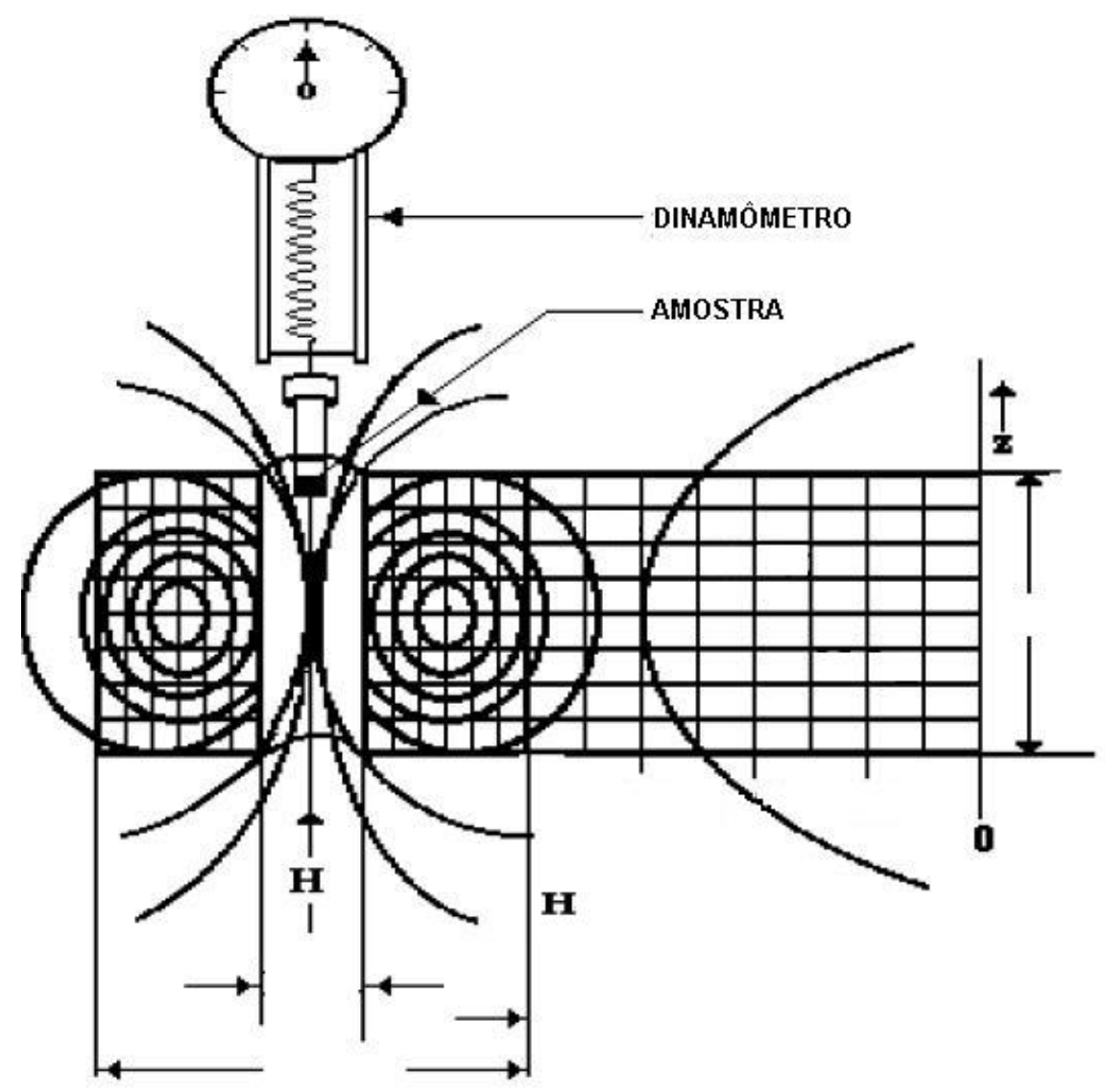

Figura 2.16 - Comportamento de minerais sob ação de campo magnético (adaptado de SAMPAIO; DA LUZ, 2004).

SAMPAIO; DA LUZ (2004) fazem a seguinte descrição do fenômeno observado: 
Quando a amostra está na parte superior do solenóide, os pesos aparentes da hematita e magnetita aumentam com o aumento do campo, o peso aparente de quartzo diminui. Se a amostra estiver situada na parte inferior do solenóide os pesos aparentes da hematita e magnetita diminuem e do quartzo aumenta. Conclui-se que a força magnética atuando na hematita e magnetita é dirigida para o centro do solenóide, onde existe um campo magnético mais elevado. No caso do quartzo a força magnética é dirigida para a extremidade onde o campo é mais fraco.

Pode-se então concluir que a atração ou repulsão das partículas pelo campo aplicado é a resposta das mesmas ao processo de separação. Observa-se que os minerais ferromagnéticos apresentam resposta rápida da indução magnética sob a ação do campo. Os minerais paramagnéticos apresentam o mesmo comportamento, mas com menor intensidade. Finalmente, os minerais diamagnéticos apresentam indução magnética com valores negativos (WILLS, 1988). Os equipamentos são classificados de acordo com a tabela 2.7.

Para se produzir um gradiente, pode-se tomar dois caminhos. O primeiro consiste na construção de um pólo de eletroímã com área muito menor que a do oposto. $\mathrm{O}$ segundo advém da introdução de matrizes entre os pólos do eletroímã. A finalidade dessas matrizes é aumentar o gradiente, deformando o campo pela produção de pontos com presença de campo de alta intensidade em seu interior. Foram utilizadas esferas, hastes, placas, grades, dentre outros. Segundo WILLS (1988), deve-se escolher a matriz que melhor se ajusta às características do minério, além de considerar o seguinte:

- gradiente máximo;

- relação entre área superficial de captação e volume da zona da matriz;

- capacidade de limpeza (retirada das partículas magnéticas) rápida, de forma a manter fluxo contínuo no sistema;

- porosidade, para permitir a vazão da polpa: caso ela seja baixa, é necessário maior pressão para obter a vazão ideal;

- material pouco resiliente: se esta for alta, torna-se difícil remover das partículas magnetizadas (tal discussão ainda é um tema de estudo intenso na área de separação magnética). 
Tabela 2.7 - Tipos de equipamentos de separação magnética.

\begin{tabular}{|c|c|c|c|c|}
\hline Tipo & $\begin{array}{c}\text { Campo } \\
\text { (T) }\end{array}$ & $\begin{array}{c}\text { Gradiente } \\
(\mathrm{T} / \mathrm{cm})\end{array}$ & Equipamentos & Aplicações \\
\hline $\begin{array}{c}\text { Baixa } \\
\text { intensidade }\end{array}$ & $\begin{array}{c}0,06- \\
0,10\end{array}$ & 0,05 & $\begin{array}{l}\text { A seco (tamanho } \\
\text { mínimo de partícula } \\
0,105 \mathrm{~mm} \text { ): ímãs } \\
\text { suspensos, polias } \\
\text { magnéticas, tambor } \\
\text { magnético } \\
\text { A úmido (tamanho } \\
\text { mínimo 0,045 mm): } \\
\text { correia submersa, } \\
\text { tambor a úmido }\end{array}$ & $\begin{array}{c}\text { Sucatas } \\
\text { Materiais } \\
\text { ferromagnéticos } \\
\text { Produtos ustulados }\end{array}$ \\
\hline $\begin{array}{c}\text { Alta } \\
\text { intensidade }\end{array}$ & $\begin{array}{l}0,10- \\
1,00\end{array}$ & 0,05 & $\begin{array}{l}\text { A seco (tamanho } \\
\text { mínimo } 0,075 \mathrm{~mm} \text { ): } \\
\text { correias cruzadas, } \\
\text { discos, rolo induzido }\end{array}$ & $\begin{array}{c}\text { Minerais } \\
\text { paramagnéticos } \\
\text { (wolframita, cromita, } \\
\text { etc.) }\end{array}$ \\
\hline $\begin{array}{c}\text { Alto } \\
\text { gradiente }\end{array}$ & $\begin{array}{l}1,00- \\
5,00\end{array}$ & $<0,10$ & $\begin{array}{l}\text { A seco (tamanho } \\
\text { mínimo } 0,045 \mathrm{~mm}) \text { : } \\
\text { rolos de terras raras, } \\
\text { tambor } \\
\text { supercondutor } \\
\text { A úmido (tamanho } \\
\text { mínimo } 0,001 \mathrm{~mm} \text { ): } \\
\text { matrizes } \\
\text { estacionárias } \\
\text { móveis, tambor } \\
\text { supercondutor }\end{array}$ & $\begin{array}{c}\text { Minerais } \\
\text { paramagnéticos } \\
\text { Carvão } \\
\text { Caulim } \\
\text { Tratamento de água }\end{array}$ \\
\hline
\end{tabular}

O separador opera da seguinte maneira. Um campo magnético alto é aplicado nas matrizes, que são sulcadas, para maximizar as forças magnéticas no interior das mesmas. A alimentação é mantida constante por meio de uma válvula por 2 s. Nesse ínterim, as partículas fortemente magnéticas ficam retidas nas matrizes e as não magnéticas atravessam a região e são descarregadas em um recipiente coletor. Em seguida, as partículas retidas na matriz são lavadas por um fluxo de água com baixa pressão, que é regulado pela ação de dois pistões hidráulicos. O tempo de lavagem é de cerca de $1,5 \mathrm{~s}$ e, após esse tempo, são coletadas as partículas fracamente magnéticas (mistas ou paramagnéticas). Finalmente, numa posição fora do campo magnético, é feita a lavagem do concentrado, com água a 40-50 psi (KELLY; SPOTTISWOOD, 1982; WILLS, 1988). 
De acordo com SAMPAIO; DA LUZ (2004), é difícil definir detalhadamente o comportamento das variáveis operacionais envolvidas na separação magnética de forma a controlá-la. Ainda assim, a otimização do processo depende essencialmente da intensidade do campo magnético e da alimentação. Materiais de alta susceptibilidade magnética são separados com menor intensidade de campo, ocorrendo o oposto para campos mais intensos. Já o efeito da intensidade do campo magnético da alimentação é verificado principalmente na separação a seco: preferivelmente, a camada de material que atravessa o campo deve ser pouco espessa (ou "de uma só partícula"), para evitar a contaminação do concentrado. Isto nem sempre é verificado na prática (BURT, 1984; WILLS, 1988).

\subsection{A PRODUÇÃO DE FERRONÍQUEL}

Diversos foram os fatores que condicionaram a evolução das rotas de processo de minérios oxidados de níquel até os tempos atuais. Hoje é possível observar a distribuição geral indicada na figura 2.17.

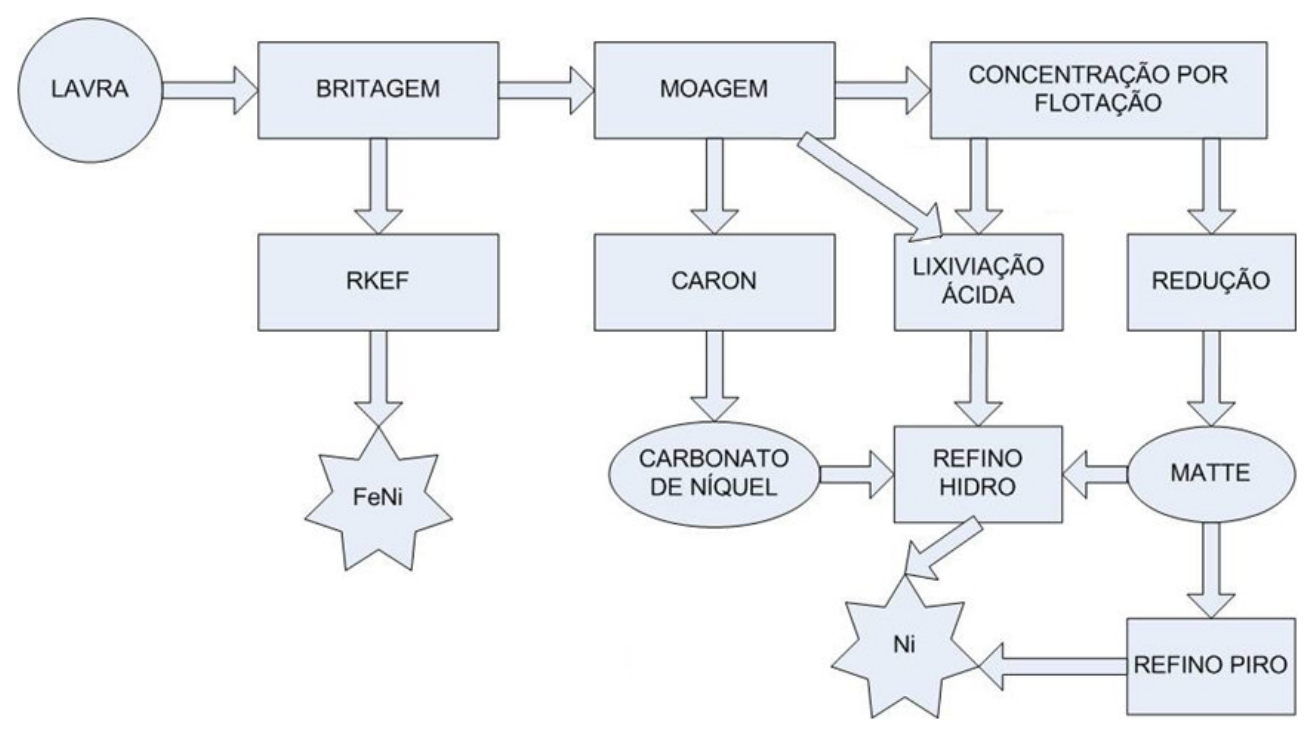

Figura 2.17 - Rotas de processamento para obtenção de níquel. 
Dado o tipo de jazida, há uma (ou mais) rota(s) de processo adequada(s). O processo Caron, também conhecido como lixiviação amoniacal, recupera essencialmente o níquel, o cobre e o cobalto contidos no minério, na forma de carbonato granular ou sínter de óxido, para posterior refino. A lixiviação ácida realiza o mesmo processo, mas o reagente principal é o ácido sulfúrico. Todas essas rotas hidrometalúrgicas buscam a obtenção do níquel metálico. Finalmente, a rota RKEF (calcinador rotativo-forno elétrico) recupera o ferro e o níquel contidos, além de parte do cobalto, em uma liga metálica, chamada de ferroníquel. A adequação destas rotas aos diferentes tipos de minério encontra-se indicada na tabela 2.8 .

Tabela 2.8 - Ocorrências minerais e suas respectivas rotas de processo (TERRY; MONHEMIUS; BURKIN, 1987; DALVI; BACON, OSBORNE, 2004).

\begin{tabular}{|c|c|c|c|c|}
\hline $\begin{array}{l}\text { Tipo de } \\
\text { Minério }\end{array}$ & Rota & Vantagens & Desvantagens & Plantas \\
\hline Limonítico & Caron & $\begin{array}{l}\text { Tolera altas } \\
\text { quantidades } \\
\text { de } \mathrm{MgO}\end{array}$ & $\begin{array}{l}\text { Presença de minério } \\
\text { saprolítico ou sílica } \\
\text { em excesso reduz a } \\
\text { recuperação } \\
\text { Alto consumo } \\
\text { energético }\end{array}$ & $\begin{array}{l}\text { Niquelândia } \\
\text { (VMN) } \\
\text { Nicaro e Punta } \\
\text { Gorda } \\
\text { (Cubaníquel) } \\
\text { Yabulu (QNI) }\end{array}$ \\
\hline $\begin{array}{l}\text { Limonítico } \\
\text { ou } \\
\text { saprolítico }\end{array}$ & $\begin{array}{c}\text { Lixiviação } \\
\text { Ácida (PAL } \\
\text { ou HPAL) }\end{array}$ & $\begin{array}{lr}\text { Tolera } & \text { a } \\
\text { presença } & \text { de } \\
\text { minério } & \\
\text { saprolítico } & \end{array}$ & $\begin{array}{l}\text { Necessidade de } \\
\text { teores baixos de } \mathrm{Mg} \\
\text { e } \mathrm{Al}\end{array}$ & $\begin{array}{l}\text { Pedro Sotto } \\
\text { Alba (Sherritt) } \\
\text { Goro (Vale) }\end{array}$ \\
\hline $\begin{array}{l}\text { Limonítico } \\
\text { ou } \\
\text { saprolítico }\end{array}$ & EPAL & $\begin{array}{l}\text { Pode consumir } \\
\text { mais minério } \\
\text { saprolítico }\end{array}$ & $\begin{array}{l}\text { Alto consumo de } \\
\text { ácido ( } 1 \mathrm{t} / \mathrm{t} \text { minério) }\end{array}$ & $\begin{array}{l}\text { Ravensthorpe } \\
(\mathrm{BHP})\end{array}$ \\
\hline $\begin{array}{l}\text { Limonítico } \\
\text { ou } \\
\text { saprolítico }\end{array}$ & $\begin{array}{l}\mathrm{AL}, \mathrm{AHL} \\
\quad \mathrm{CL}\end{array}$ & $\begin{array}{l}\text { Pode consumir } \\
\text { mais minério } \\
\text { saprolítico }\end{array}$ & $\begin{array}{l}\text { Ainda em etapa de } \\
\text { testes (escala piloto) }\end{array}$ & Nenhuma \\
\hline Saprolítico & RKEF & $\begin{array}{l}\text { Baixo } \\
\text { consumo } \\
\text { energético } \\
\text { Alta } \\
\text { recuperação }\end{array}$ & $\begin{array}{lr}\text { Sensível a } & \text { grandes } \\
\text { oscilações } & \text { na } \\
\text { relação } & \text { sílica- } \\
\text { magnésio } & \\
& \end{array}$ & $\begin{array}{l}\text { Falcondo } \\
\text { (Xstrata) } \\
\text { Pamco (Anglo) } \\
\text { Aneka } \\
\text { Tambang (Vale) }\end{array}$ \\
\hline
\end{tabular}


Cabe ressaltar que a descrição das rotas acima é válida apenas para minerais lateríticos. No caso de minerais sulfetados, a rota clássica é a metalurgia de mattes. Apenas a produção de ferroníquel a partir do minério saprolítico, que é o foco deste trabalho, será descrita a seguir.

\subsubsection{HISTÓRICO}

As primeiras jazidas de níquel de grande porte foram descobertas no Canadá (minério sulfetado) e na Nova Caledônia (minério oxidado), uma ilha localizada a leste da Austrália, na segunda metade do século XIX. Como o principal mercado consumidor, a Europa, era muito distante de lá, e o minério muito pobre para sustentar o custo de transporte, foi identificada a necessidade de se efetuar a redução do minério na própria ilha (DALVI; BACON, OSBORNE, 2004). A primeira usina iniciou suas operações em Pointe Chaleix, Nouméa, em 1879, e duas outras (uma em Doniambo e outra em Thio), em 1910 e 1913, respectivamente. Essas operações foram responsáveis pelo fornecimento de minério às usinas que se instalaram posteriormente no Japão e na Austrália (no caso, Yabulu, que recebia o minério limonítico).

Na Rússia, apesar de conhecidas desde o século XVII, as jazidas de níquel e cobre da península de Taimyr, noroeste da Sibéria, começaram a ser exploradas depois dos anos 1920. Em 1934, durante o Segundo Plano Qüinqüenal, uma usina em Verkhnii Ufalei, na região dos Urais, iniciou as operações. Em seguida, em 1935, a usina que deu origem à Norilsk começou a operar a $2.000 \mathrm{~km}$ ao norte de Krasnoyarsk, Sibéria. Em 1947, após extensas pesquisas, foram descobertas enormes jazidas de níquel e cobre, principalmente sulfetados. Estes esforços deram à União Soviética o poderio industrial e a capacidade produtiva que hoje resultam numa participação de mercado de 20\%, conforme a tabela 2.9 (NORISLK NICKEL, 2008).

A Nova Caledônia possui até hoje uma cultura muito desenvolvida com relação ao processamento de minério saprolítico. A capacidade anual de processamento de 
minério é de cerca de 6,5 milhões de toneladas, resultando em mais de $60.000 \mathrm{t}$ de níquel (contido no FeNi) ao ano (DALVI; BACON, OSBORNE, 2004). Junto a ela, hoje compõem o portfólio de produtores de níquel os seguintes países:

Tabela 2.9 - Produção e reservas de níquel (KUCK, 2006).

\begin{tabular}{|c|c|c|c|}
\hline \multirow{2}{*}{ País } & \multicolumn{2}{|c|}{$\begin{array}{c}\text { Produção anual (t } \\
\text { métricas) }\end{array}$} & $\begin{array}{c}\text { Reservas em } \\
\mathbf{2 0 0 5}(\mathbf{t} \\
\text { métricas) }\end{array}$ \\
\cline { 2 - 3 } & $\mathbf{2 0 0 4}$ & $\mathbf{2 0 0 5}$ & 3.700 .000 \\
\hline África do Sul & 39.900 & 41.700 & 22.000 .000 \\
\hline Austrália & 178.000 & 210.000 & 490.000 \\
\hline Botsuana & 33.000 & 37.100 & 4.500 .000 \\
\hline Brasil & 45.200 & 46.000 & 4.900 .000 \\
\hline Canadá & 187.000 & 196.000 & 1.100 .000 \\
\hline China & 64.000 & 71.000 & 830.000 \\
\hline Colômbia & 75.000 & 72.500 & 5.600 .000 \\
\hline Cuba & 72.400 & 75.000 & 940.000 \\
\hline Filipinas & 17.000 & 22.000 & 490.000 \\
\hline Grécia & 21.700 & 22.100 & 3.200 .000 \\
\hline Indonésia & 133.000 & 140.000 & 4.400 .000 \\
\hline Nova Caledônia & 118.000 & 122.000 & 720.000 \\
\hline República Dominicana & 47.000 & 47.000 & 6.600 .000 \\
\hline Rússia & 315.000 & 315.000 & 560.000 \\
\hline Venezuela & 20.500 & 22.000 & 15.000 \\
\hline Zimbábue & 9.520 & 9.800 & 2.100 .000 \\
\hline Outros países & 11.000 & 26.000 & 62.000 .000 \\
\hline TOTAL MUNDIAL (arredondado) & 1.400 .000 & 1.500 .000 & \\
\hline & & & \\
\hline
\end{tabular}

A maior utilização do níquel é para a produção de aço inoxidável, que responde por cerca de $60 \%$ do consumo do metal (CRANFIELD, 2006). O crescente uso do processamento de jazidas lateríticas para a obtenção de ferroníquel, junto à necessidade de mercado citada, culminou no desenvolvimento da rota conhecida como RKEF (rotary kiln-electric furnace, ou calcinador rotativo-forno elétrico). Esta configuração de equipamentos é interessante pelos seguintes motivos: 
- O consumo energético é baixo, cerca de $15 \mathrm{kWh}$ por tonelada de níquel produzida: rotas como o Caron e a PAL (antecessora do HPAL) consomem 25 kWh/t e 20 kWh/t, respectivamente (TERRY; MONHEMIUS; BURKIN, 1987);

- O produto final obtido, o ferroníquel, não interfere negativamente nas etapas subseqüentes da cadeia produtiva, por possuir baixíssimas quantidades de carbono, enxofre, fósforo e silício, que interferem substancialmente na qualidade do aço (MOURÃO, 2007).

\subsubsection{A ROTA RKEF}

No início, descobriu-se que o níquel não se encontrava disponível na natureza em forma metálica (VOLK, 1970). Para obtê-lo, havia a necessidade de reagi-lo com um material carbonoso que reduzisse o mineral nativo ao metal, de acordo com a seguinte reação:

$$
\mathrm{NiO}_{(s)}+\mathrm{CO}_{(g)} \rightarrow \mathrm{Ni}_{(s)}^{0}+\mathrm{CO}_{2(g)}
$$

No Canadá, inicialmente, utilizava-se madeira picada, oriunda das florestas abundantes do entorno. Hoje, a região de Sudbury possui quase nenhuma cobertura vegetal, tanto devido ao consumo das árvores como meio redutor quanto à ocorrência de chuvas ácidas no local durante o último século (EC, 2001).

O que se fazia, também na Nova Caledônia, era adicionar um meio redutor ao minério (madeira, à época) e submetê-lo à redução. Devido às características do minério (alta umidade, alta relação sílica-magnésio, etc.), esta maneira de realizar o processo resultava em muitos inconvenientes operacionais (DEGEL, 2006). De forma a diminuir as massas manuseadas no forno e melhorar os consumos de energia elétrica e de meio redutor, tentou-se secar o minério antes de colocá-lo no forno. Esta primeira melhoria diminuiu consideravelmente os rompimentos dos eletrodos e as explosões no interior da cuba, o que aumentou o tempo de campanha do forno e a disponibilidade operacional.

A figura 2.18 ilustra o diagrama ternário $\mathrm{SiO}_{2}-\mathrm{MgO}-\mathrm{NiO}$. 


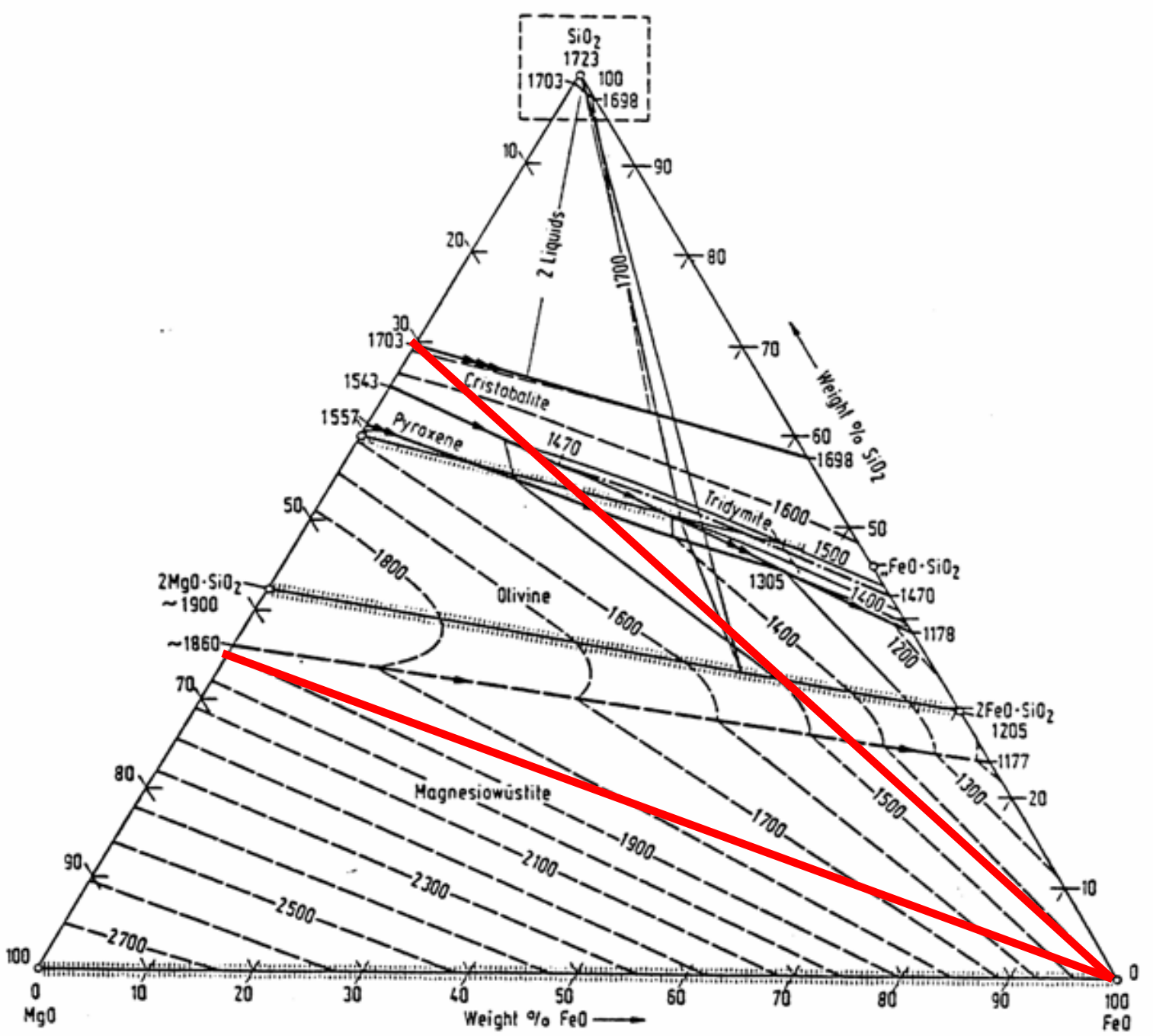

Figura 2.18 - Diagrama de fases $\mathrm{SiO}_{2}-\mathrm{MgO}-\mathrm{NiO}$ (DEGEL, 2006).

Se o minério encaminhado para a pirometalurgia para fabricação de ferroníquel tiver muita sílica (parte superior do triângulo), demandará quantidades significativas de cal ou dolomita para escorificá-lo. O forno então ficará cheio de escória e a maior parte da energia será consumida para formá-la e fundi-la. Este mesmo minério, dado o caráter ácido de sua ganga, não é recomendado nem para o processo Caron, mas para a lixiviação ácida.

Correspondentemente, o minério de alto teor de magnésia (parte inferior do triângulo, à esquerda) exigirá grandes quantidades de sílica para ser escorificado, consumindo também muita energia de escorificação e fusão. Dado o caráter 
alcalino de sua ganga magnesiana, ele é totalmente inadequado para os processos de lixiviação ácida, recomendando-se o processo Caron, portanto.

Já os minérios intermediários (faixa central do triângulo) têm quantidades significativas dos minerais nocivos tanto para a lixiviação amoniacal como para a lixiviação ácida. Entretanto, as gangas ácida e alcalina se equilibram, tornando-o adequado para a pirometalurgia de ferroníquel.

A partir de um estudo mais aprofundado das características dos produtos do forno, assim como do minério, foi possível concluir que o diagrama indicado na figura 2.18 era uma aproximação adequada das características da escória produzida no forno elétrico.

De acordo com BUTTS (1943), a presença de água na carga adicionada a um forno de redução a arco "pode representar uma grande carga térmica para o forno", uma vez que grande quantidade de calor terá que ser dispendida para retirar a mesma do material. Também ocorre diminuição da temperatura do forno e, conseqüentemente, o tempo necessário para a fusão completa da carga (DEGEL, 2006). Em conversores de cobre e na indústria do ferroníquel, ocorre reação violenta da carga, provocando diminuição da vida do conversor ou do forno (BUTTS, 1943; DEGEL, 2006).

Outro efeito importante da umidade do material apresenta-se no seu manuseio. É comum observar problemas operacionais nas áreas de preparação e armazenamento de minério, devidos à coesividade do minério úmido. Em testes realizados na Austrália, foi possível observar que o minério chega a aderir a superfícies porosas posicionadas a 90ํㅡㅇ com piso.

Ainda que o minério estivesse superficialmente seco, a carga ainda era muito instável dentro do forno. Durante a década de 1950, descobriu-se que, além da umidade, uma grande quantidade de água de constituição, ou de perda ao fogo, existia no minério e precisava ser eliminada antes de seu ingresso no forno de 
redução (DEGEL, 2006). Além do secador, demandava-se, então, uma etapa de calcinação. Foi então consolidada a rota RKEF, ilustrada na figura 2.19.

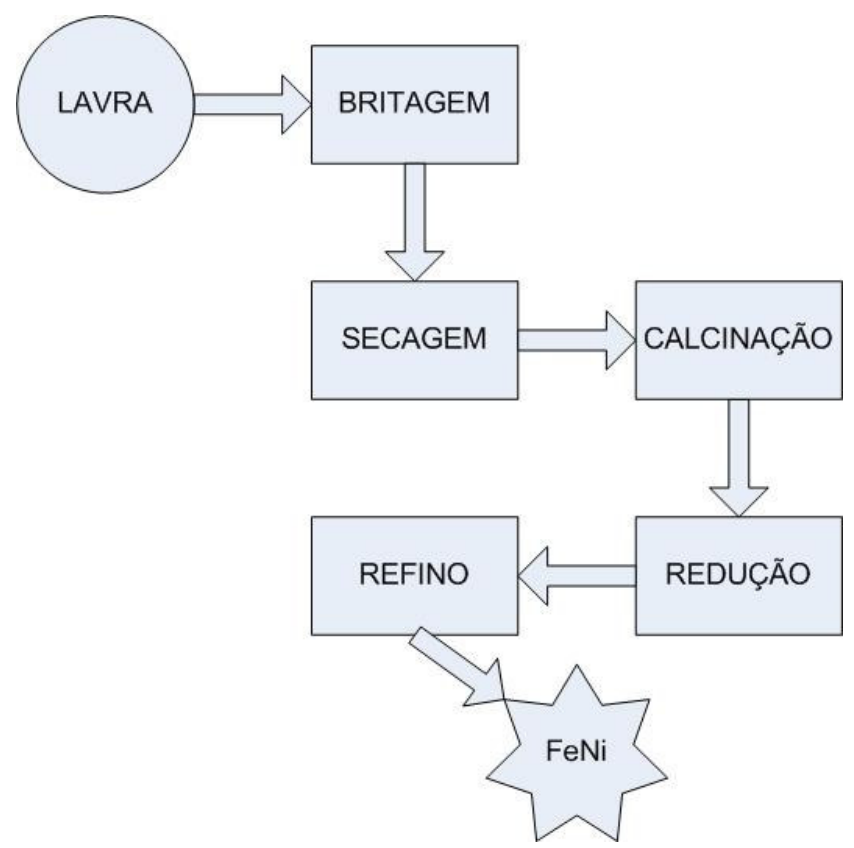

Figura 2.19 - A rota RKEF.

Esta configuração de equipamentos é utilizada hoje pela maioria das usinas produtoras de ferroníquel do mundo, como Cerro Matoso (BHP, Colômbia), Doniambo (SLN, Nova Caledônia), Codemin (Anglo American, Brasil), Aneka Tambang (Vale, Indonésia) e Loma de Níquel (Anglo American, Venezuela), dentre outras. As operações unitárias envolvidas serão descritas a seguir.

\subsubsection{BRITAGEM}

A lavra é normalmente realizada por escavação mecânica e em alguns casos são feitos desmontes com explosivos. O minério sai da lavra com tamanho máximo típico de 800 mm, podendo variar entre 600 e 1200 mm, e umidade normalmente entre 25 e 35\%. Pode ser transportado por teleférico, transportador de correia ou caminhões até a estação de britagem - nos dois primeiros modais, o minério necessita ser submetido a uma britagem prévia. 
Uma vez que o minério encontra-se disponível para o processamento, é necessário prepará-lo para alimentar o forno de redução. Realizam-se então as seguintes operações unitárias: cominuição, aglomeração de pó, secagem e calcinação.

As operações de cominuição normalmente abrangem apenas britagem em vários estágios. Uma exceção é a Falcondo, operação da Xstrata na República Dominicana, que mói todo o material a seco para pelotizá-lo antes de enviá-lo aos fornos de calcinação verticais. Esta usina passa hoje por mudanças na rota de processo e provavelmente o minério será apenas britado. As tabelas 2.11 e 2.12 comparam algumas operações em função de seus estágios de britagem.

Tabela 2.10 - Sistemas de britagem de usinas de ferroníquel brasileiras.

\begin{tabular}{|l|c|c|c|c|c|}
\hline \multicolumn{1}{|c|}{ Característica } & Unid. & Codemin & Barro Alto & Morro Azul & Onça Puma \\
\hline Estágios & - & 3 & 4 & 2 & 2 \\
\hline Tamanho máximo, ROM & $\mathrm{mm}$ & 300 & 800 & 300 & 600 \\
\hline Tamanho máximo, produto & $\mathrm{mm}$ & 30 & 30 & 30 & 50 \\
\hline Relação de redução & - & 10 & 26,7 & 10 & 12 \\
\hline Vazão instantânea (úmida) & $\mathrm{t} / \mathrm{h}$ & 350 & 800 & 100 & 1000 \\
\hline
\end{tabular}

Tabela 2.11 - Sistemas de britagem de usinas de ferroníquel estrangeiras.

\begin{tabular}{|l|c|c|c|c|}
\hline \multicolumn{1}{|c|}{ Característica } & Unid. & Loma de Níquel & Fenix & Cerro Matoso \\
\hline Estágios & - & 3 & 2 & 2 \\
\hline Tamanho máximo, ROM & $\mathrm{mm}$ & 600 & 610 & 800 \\
\hline Tamanho máximo, produto & $\mathrm{mm}$ & 30 & 38 & 75 \\
\hline Relação de redução & - & 20 & 16 & 10,7 \\
\hline Vazão instantânea (úmida) & $\mathrm{t} / \mathrm{h}$ & 500 & 1000 & 1000 \\
\hline
\end{tabular}

Cabe ressaltar que Loma de Níquel inicialmente operava com circuito em dois estágios e material em 75-80 mm alimentado ao calcinador. Esta configuração original do projeto foi alterada, devido a vários inconvenientes de processo desgaste prematuro dos equipamentos, intensa formação de calcinado grosso e outros efeitos -, sendo que todos foram plenamente resolvidos com a adoção do novo tamanho de produto (30 mm) e a substituição de alguns equipamentos. 
A britagem é realizada normalmente em dois ou três estágios - há usinas que operam com quatro estágios, mais raramente. Os tamanhos máximos de produto costumam variar entre 30 e $75 \mathrm{~mm}$, dependendo do número de estágios e do tamanho máximo alimentado. Existe uma operação, chamada de upgrade, que é muito praticada junto à britagem e consiste em escalpar o material para retirar a fração grossa, com o objetivo de aumentar o teor de níquel alimentado à usina fração essa denominada proto-minério, ou seja, material não lateritizado. Isto somente é possível se o níquel e outros parâmetros de interesse tiverem uma concentração preferencial em alguma faixa granulométrica, apresentando certas faixas com ausência de níquel. Então, o material passante no escalpe segue adiante no processo.

\subsubsection{SECAGEM E CALCINAÇÃO}

Como o minério chega muito úmido à planta, é realizada uma operação de secagem em secador rotativo com queimador a GLP, óleo combustível, carvão pulverizado ou outro qualquer. Uma tendência atual é a retirada da secagem, para redução no investimento e no consumo de energia elétrica. Este processo, substituído por secagem ao tempo em pátios semicobertos, já é praticado na Codemin, na Morro Azul e na usina de Niquelândia (processo Caron). Em Niquelândia, o material é estocado para garantir o suprimento na época das chuvas. Ele fica secando ao tempo, é revolvido com arado para expor a porção úmida que está por baixo e coberto com lona para evitar a chuva. A umidade resultante fica ao redor de 33\%. Na britagem em britadores de impacto, é injetado ar quente para secar o minério. A retirada da fração grosseira, rica em quartzo, calcedônia e proto-minério é feita nesta etapa, eliminando-se assim as frações mais pobres em $\mathrm{Ni}$ e Co. Enriquece-se o minério e diminui-se sensivelmente os WI e Al.

Após a secagem, os pós coletados em todas as etapas do processo são reciclados e alimentados à calcinação junto ao minério, após serem aglomerados. Aí podem ser utilizadas três rotas de processo distintas: a pelotização, a extrusão e a mistura. 
Antes de entrar no calcinador, o minério seco recebe então o pó aglomerado e uma quantidade adequada de redutor (carvão mineral, carvão vegetal, óleo, gasóleo ou madeira) antes de ser calcinado. Uma vez lá dentro, as umidades superficial e intersticial são removidas e o ferro, o níquel e o cobalto são reduzidos parcialmente às suas formas metálicas. A uma temperatura de cerca de $900^{\circ} \mathrm{C}$, o calcinado é descarregado e alimentado ao forno elétrico. Uma vista em corte de um forno rotativo típico é mostrada na figura 2.20.

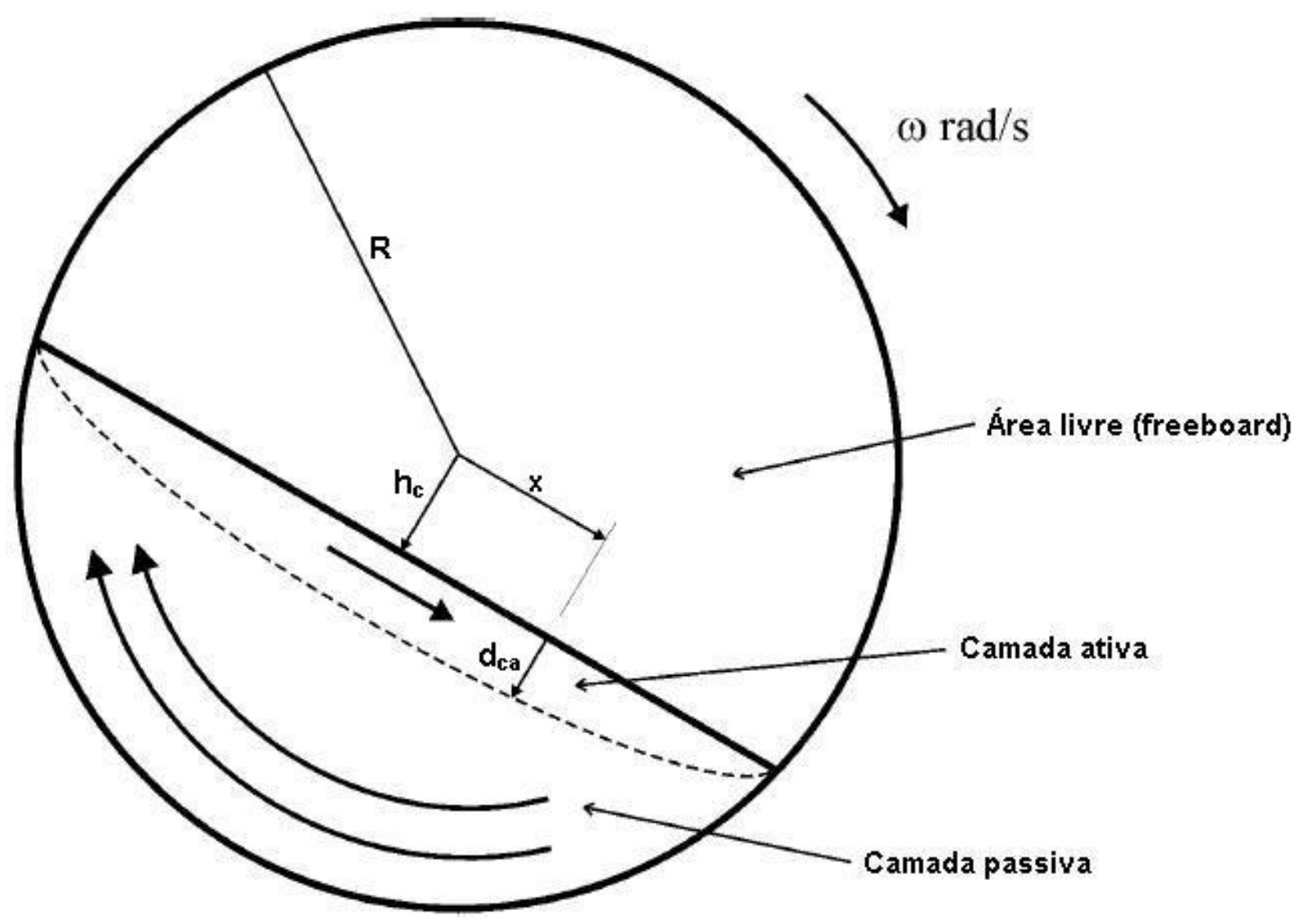

Figura 2.20 - Seção transversal de um forno rotativo (adaptado de HEYDENRYCH, 2001).

Num secador, a camada ativa, que possui espessura infinitesimalmente pequena, permanece em contato com os gases que fluem sobre a mesma, ao longo da área livre, de forma que a umidade superficial passa para os gases e é então removida. Já no calcinador rotativo, o restante da umidade superficial e também a perda ao fogo são retiradas do leito (HEYDENRYCH, 2001). Devido à adição de 
material redutor, ocorrem também as reações de redução indicadas pela Eq. (12) anterior, assim como:

$$
\begin{gathered}
\mathrm{CuO}_{(s)}+\mathrm{CO}_{(g)} \rightarrow \mathrm{Cu}_{(s)}^{0}+\mathrm{CO}_{2(g)} \\
\mathrm{CoO}_{(s)}+\mathrm{CO}_{(g)} \rightarrow \mathrm{Co}_{(s)}^{0}+\mathrm{CO}_{2(g)} \\
\mathrm{Fe}_{2} \mathrm{O}_{3(s)}+\mathrm{CO} \mathrm{O}_{(g)} \rightarrow 2 \mathrm{FeO}_{(s)}+\mathrm{CO}_{2(g)} \\
\mathrm{Fe}_{2} \mathrm{O}_{3(s)}+\mathrm{FeO}_{(s)} \rightarrow \mathrm{Fe}_{3} \mathrm{O}_{4(s)}
\end{gathered}
$$

A água superficial é removida apenas por vaporização, sem que ocorram reações. Também é removida a água de cristalização, a partir de certa temperatura, normalmente ao longo da segunda metade do percurso do material ao longo do forno. Finalmente, no último terço do forno e na presença de redutor, são iniciadas as reações de redução dos metais presentes (DOR; SKRETTING, 1979).

O produto final, chamado de calcinado, é enviado ao forno elétrico para continuar com o processo de redução e obter os metais em suas formas reduzidas.

\subsubsection{REDUÇÃO}

A redução é realizada em forno elétrico a arco de corrente alternada, cujo arranjo típico é indicado na figura 2.23. Fornos circulares (como os existentes em Falcondo, Cerro Matoso, Aneka Tambang, Codemin) normalmente possuem três eletrodos em dispostos em triângulo, enquanto que fornos retangulares (Onça Puma, Barro Alto) possuem seis eletrodos em linha (ALMEIDA; SILVEIRA, 1990; SILVEIRA, 1997). 


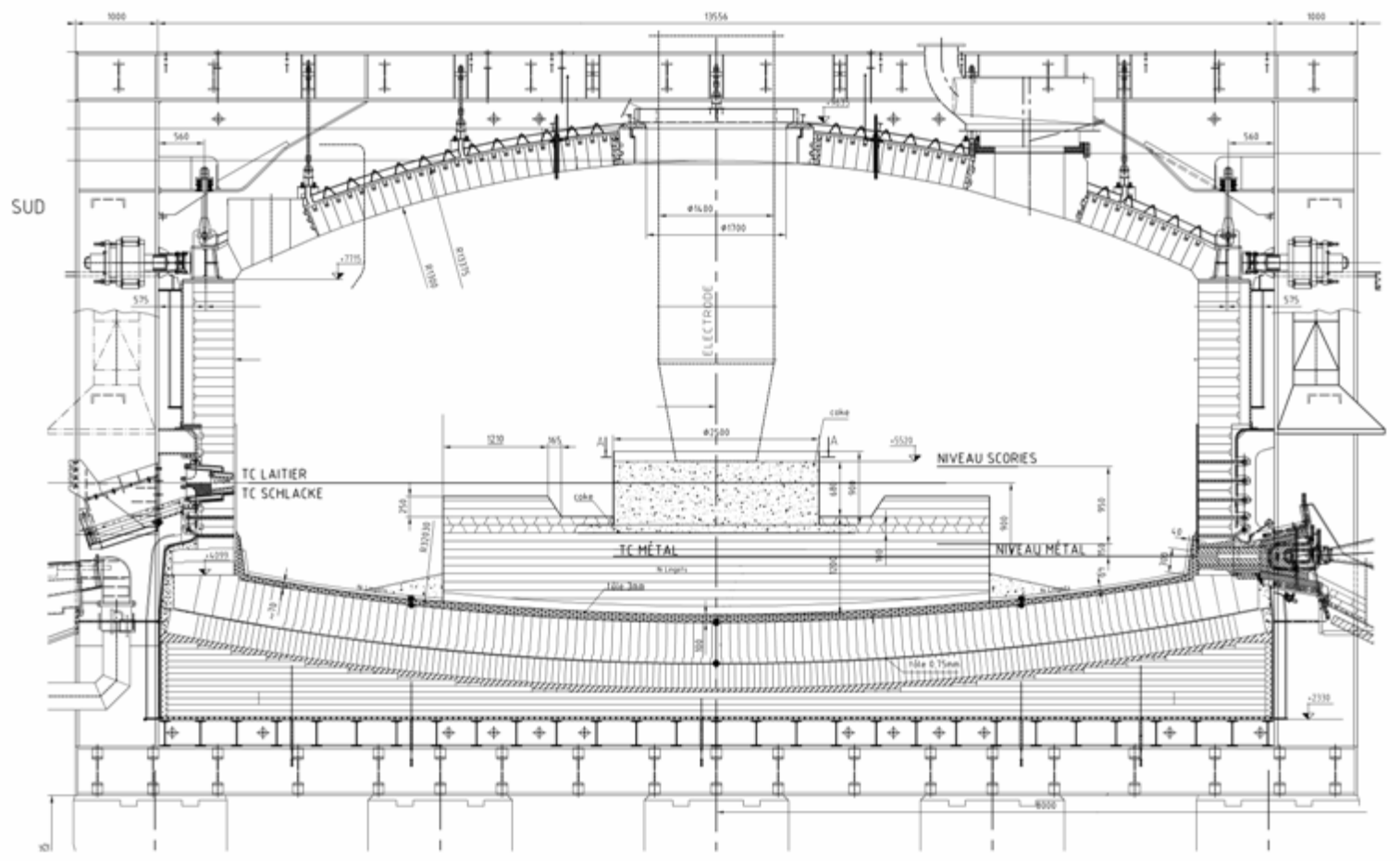

Figura 2.23 - Seção transversal de forno a arco (DEGEL, 2006).

O calcinado é fundido e reduzido e o enorme gradiente térmico causa revolvimento do material no interior do forno. Com isso, a escória sobe $\left(\mathrm{SiO}_{2}\right.$, $\mathrm{MgO}, \mathrm{FeO}, \mathrm{Al}_{2} \mathrm{O}_{3}$, etc.) e as fases metálicas descem (Fe, $\mathrm{Ni}, \mathrm{Co}, \mathrm{Cu}$, etc.). As impurezas ( $\mathrm{C}, \mathrm{S}, \mathrm{P}$, etc.) são incorporadas à escória - efeito que necessita de uma escória com fluidez adequada (SOUZA SANTOS, 1960). De acordo com SILVEIRA (1997) e DEGEL (2006), os principais fatores que influenciam a operação do forno são:

- temperatura, metalização e perda ao fogo do calcinado;

- projeto do sistema de carregamento e monitoramento de nível de carga;

- razão entre potência do banho e do arco;

- carga específica do leito;

- fornecimento de energia; e

- sistema de resfriamento da carcaça.

O principal mecanismo de fornecimento de energia ao banho é pela resistência combinada do arco mais a escória. Em teoria, seriam necessários cerca de 6600 kWh/t FeNi produzida, considerando um calcinado alimentado com menos de 1\% 
de perda ao fogo e mais de $850{ }^{\circ} \mathrm{C}$ de temperatura na descarga do calcinador (SILVEIRA, 1997; DEGEL, 2006). Considerando que a temperatura da escória próxima do arco é superior à do vazamento, observa-se também uma variação na condutividade elétrica da escória, conforme figura 2.22.
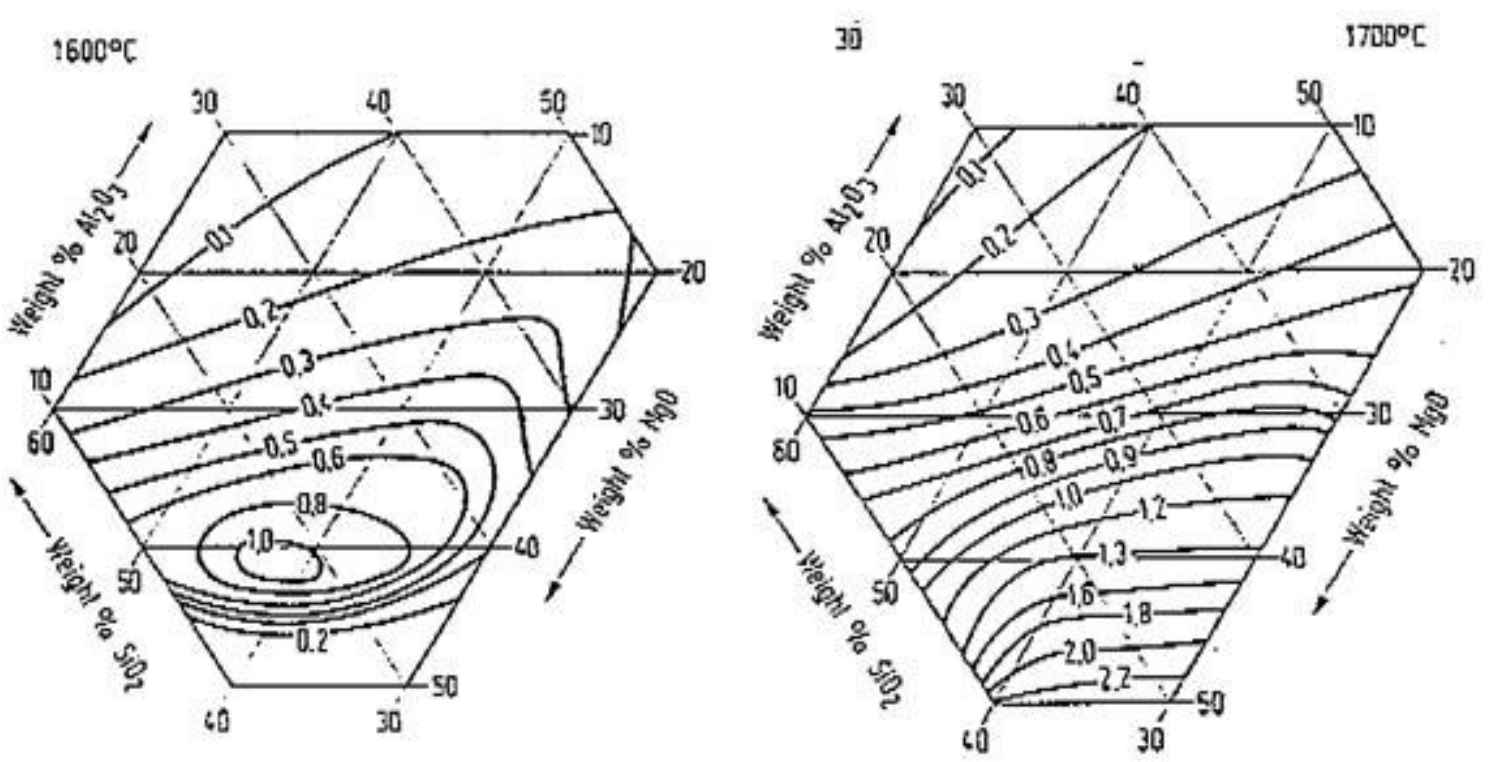

Figura 2.22 - Correlação entre temperatura e condutividade elétrica da escória (SOUZA SANTOS, 1960; SILVEIRA, 1997; DEGEL, 2006).

Cabe ressaltar que o consumo energético desta etapa do processo é de grande importância. Em várias plantas, chega a responder por mais de $50 \%$ dos custos operacionais (DALVI; BACON; OSBORNE, 2004).

$\mathrm{Na}$ experiência prática, quantidades significativas de $\mathrm{Fe}^{2+}$ reduzidas a metal no forno elétrico resultam em uma liga de baixo teor (15-25\% Ni), assim como maiores quantidades de $\mathrm{C}, \mathrm{Cr}$ e Si na fase metálica. Por outro lado, no caso de quantidades menores de ferro a serem reduzidas, obtém-se um ferroníquel com $>30 \% \mathrm{Ni}$ e níveis baixos de $\mathrm{C}, \mathrm{Cr}$ e $\mathrm{Si}$. Independentemente do teor de $\mathrm{Ni}$, o metal conterá quantidades variáveis de $\mathrm{S}$ e $\mathrm{P}$, dependendo de suas quantidades existentes no calcinado e as características do combustível e do agente redutor empregados nas etapas de secagem e calcinação (DOR; SKRETTING, 1979). 
Periodicamente o forno é vazado para remoção de metal e escória. A escória pode ser granulada ou depositada a quente em uma área preparada para este fim. Já o metal é levado à etapa secundária, denominada refino.

\subsubsection{REFINO}

De acordo com SILVEIRA (1997) e MOURÃO (2007), as principais impurezas resultantes do processo de produção de aço são: carbono, hidrogênio, nitrogênio, oxigênio, enxofre e fósforo. Todas elas podem ser removidas numa etapa secundária denominada refino, que engloba uma seqüência de operações de aquecimento químico e/ou elétrico, de forma a aumentar e manter a temperatura do banho num ponto adequado para a formação de nova escória, esta de refino, e a conseqüente remoção das impurezas.

Também é realizada a adição de agentes fluxantes ao banho (fluorita), formadores de escória (como cal, dolomita e sílica), elementos de liga (ferrossilício e cálcio-silício) e desoxidantes (alumínio), dentre outros. A escória, por sua vez, é removida com o auxílio de ferramentas automáticas (escumador ou slag rake) ou manuais (um toco de madeira fixado à ponta de uma haste metálica). O operador remove cuidadosamente a escória da parte superior do banho, buscando não retirar o metal refinado do mesmo e, desta forma, manter alta a recuperação metalúrgica do processo (SILVEIRA, 1997; DALVI; BACON; OSBORNE, 2004).

Em usinas de ferroníquel, o produto do forno elétrico não possui nitrogênio nem hidrogênio. Em contrapartida, arrasta silício, cromo, cobalto e cobre. Estes últimos três não podem ser removidos do banho, devido às suas características químicas. Já o silício é removido do banho naturalmente (ROSENQVIST, 2004). Normalmente, por afinidade química, são realizadas as seguintes operações (DOR; SKRETTING, 1979):

- vazamento do forno, onde se realiza aquecimento químico com oxigênio e se adicionam os primeiros fundentes. São retirados Si, C e P; 
- pesagem e transferência da panela para a estação de aquecimento elétrico, onde a escória formada no vazamento é condicionada;

- retirada da escória formada e retorno ao aquecimento elétrico;

- adição de fundentes e aquecimento elétrico até formação de nova escória, que é também retirada. Esta etapa é realizada para retirada de $\mathrm{S}$ e repetida quantas vezes for necessário; e

- retirada de alumínio (dealuminização), com aquecimento elétrico e adição final de fundentes. A escória então é retirada e a panela, contendo ferroníquel refinado, é então levada para a etapa de preparação de produto final.

O banho é agitado vigorosamente com injeção de gases inertes ( $\mathrm{N}_{2}$ ou $\mathrm{Ar}$ ) e/ou agitadores eletromagnéticos, de forma a liberar os elementos indesejados e permitir que os mesmos sejam encaminhados para a superfície livre do banho. Neste ponto, ocorre a remoção dos mesmos.

As escórias produzidas podem ser resfriadas ou granuladas com água, de acordo com o que será descrito posteriormente. Como contêm muito níquel, cada vez mais as usinas têm procurado recuperar o metal contido nestas escórias. Este é exatamente o tema deste trabalho - e, para realizá-lo, foi estabelecida uma parceria com a Mineração Morro Azul, que será descrita no capítulo 3.

\subsubsection{EXPEDIÇÃO DE PRODUTO FINAL}

Uma vez refinado, o metal precisa ser adequado às etapas subseqüentes de processamento. O uso principal do ferroníquel é na indústria do aço (CRANFIELD, 2006; KUCK, 2006), o que determina que o produto seja enviado aos clientes na forma de granulado bitolado (shot) ou lingotes. A forma de envio, seja big bags, contêineres ou por caminhão, é assim decidida também (DALVI; BACON; OSBORNE, 2004). No caso de lingotes, o metal é depositado sobre um molde. Após seu resfriamento ao ar, é lançado em um tanque com água para que possa ser manuseado. Normalmente, os moldes estão acoplados em série e são 
movidos por um acionamento. Um equipamento típico encontra-se indicado nas figuras 2.23 e 2.24 .

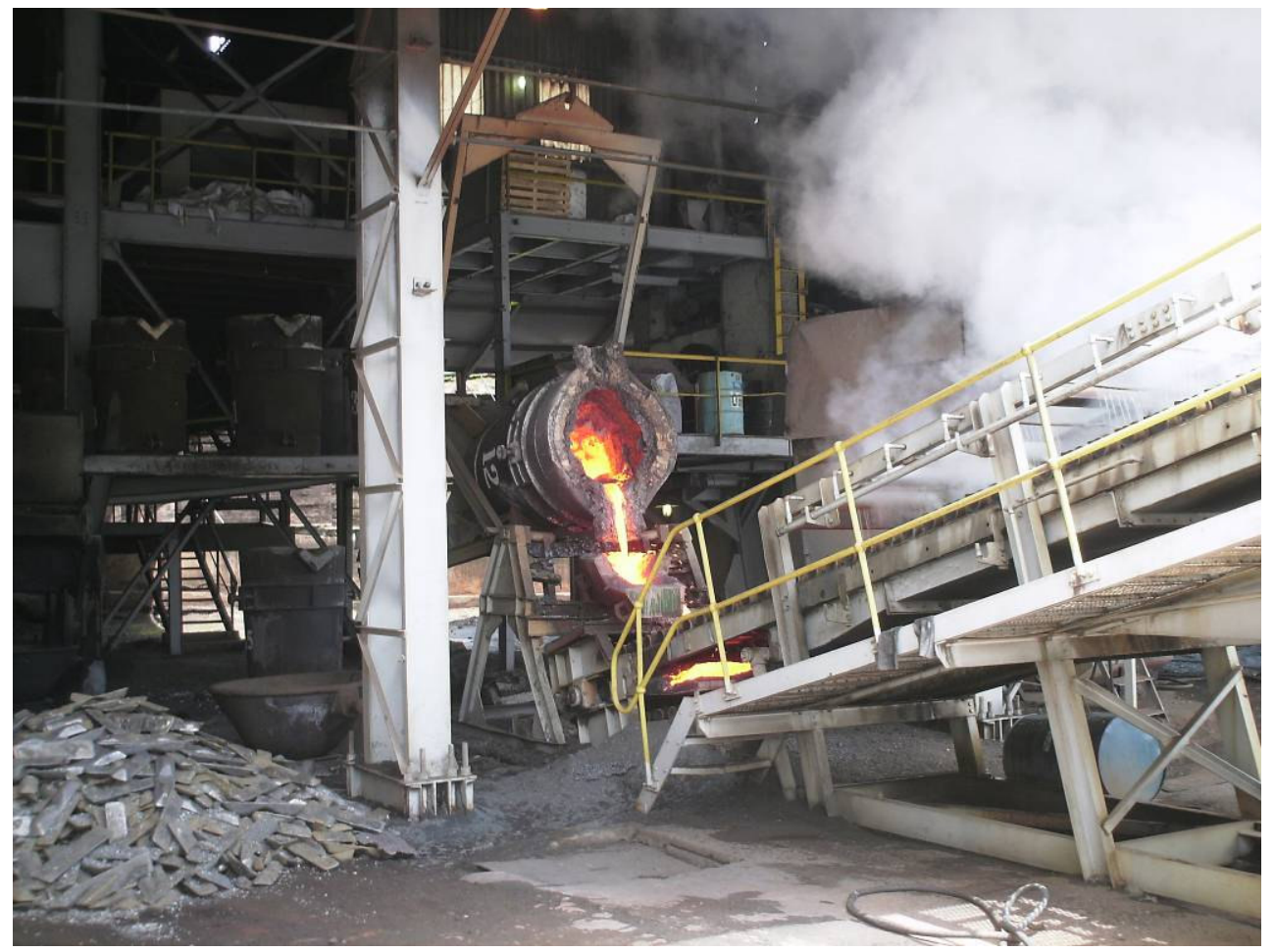

Figura 2.23 - Panela posicionada para lingotamento na Morro Azul.

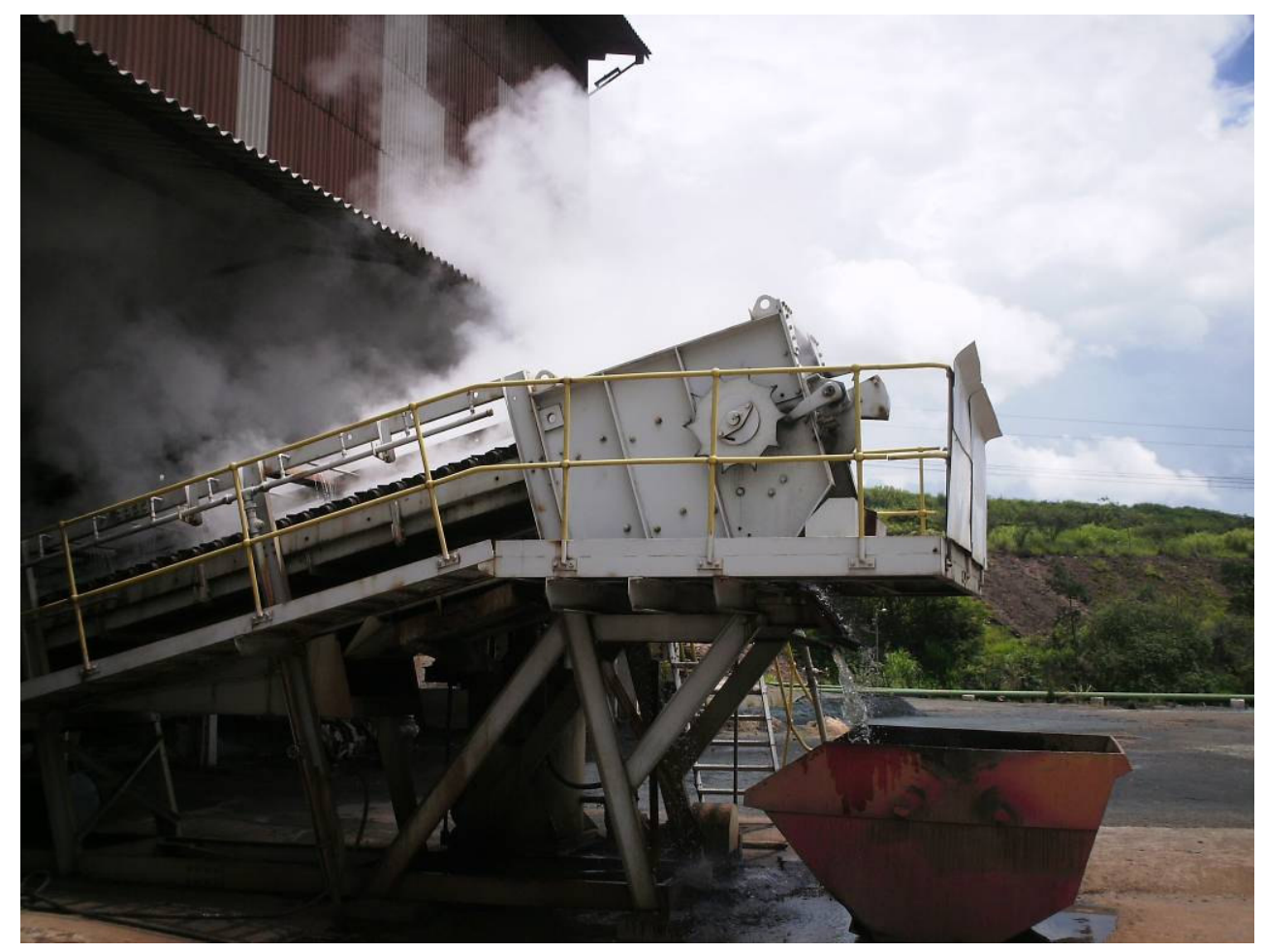

Figura 2.24 - Descarga da lingoteira da Morro Azul. 
No caso da granulação, o metal é depositado sobre um ou dois tanques contendo grande quantidade de água, a qual é alimentada continuamente ao sistema, como pode ser observado na figura 2.25 .

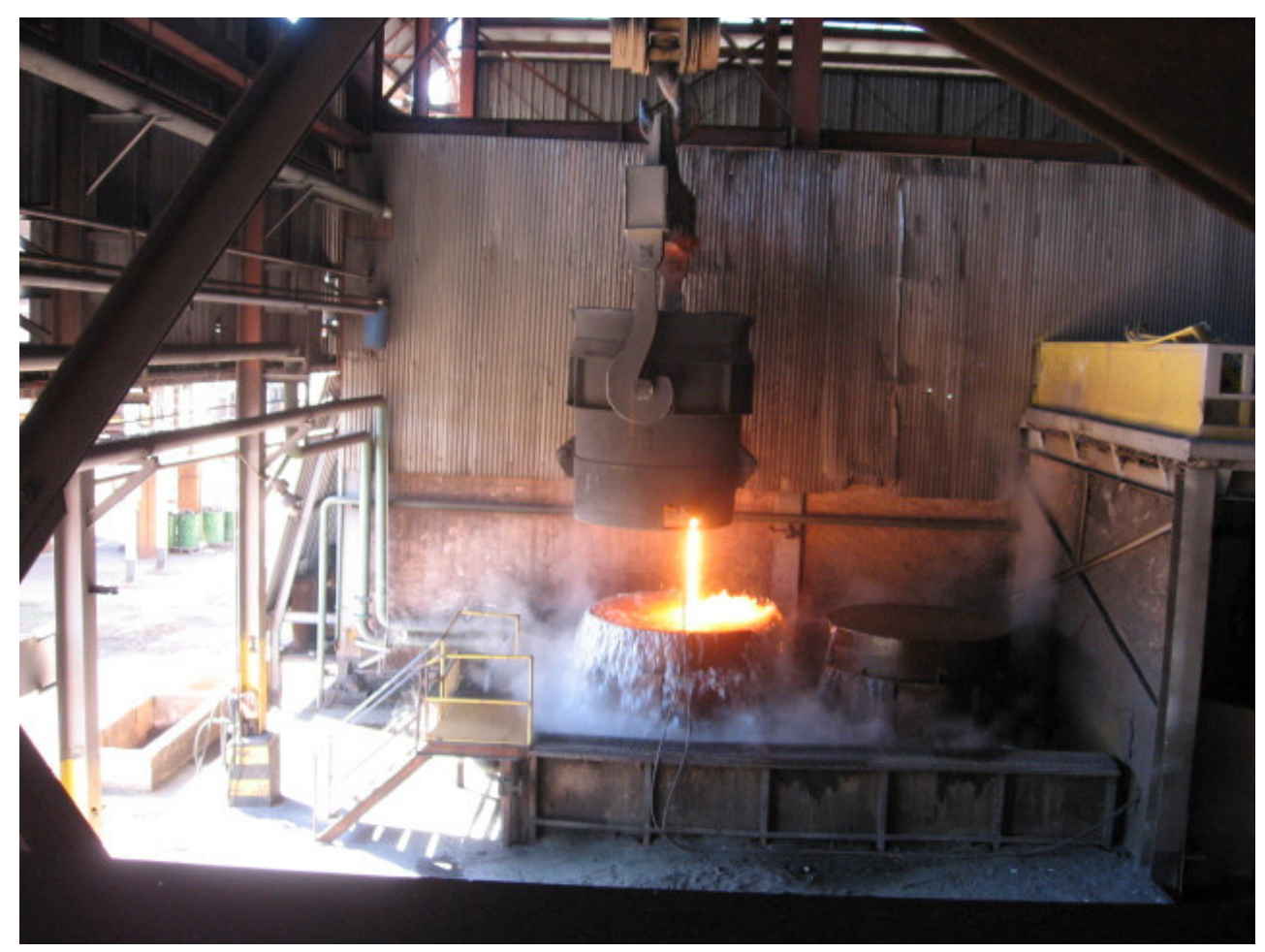

Figura 2.25 - Granulação de metal da Codemin.

Após o término do processo, quase a totalidade da água é retirada por transbordo, e o restante por um secador rotativo. Depois de seco, o material sofre peneiramento. Os produtos do peneiramento (tipicamente $-100+6,35 \mathrm{~mm},-6,35$ +2 mm e -2 mm) são ensacados ou dispostos em contêineres ou caminhões para despacho. A figura 2.26 ilustra o secador e, mais acima e com menor diâmetro, a peneira rotativa. 


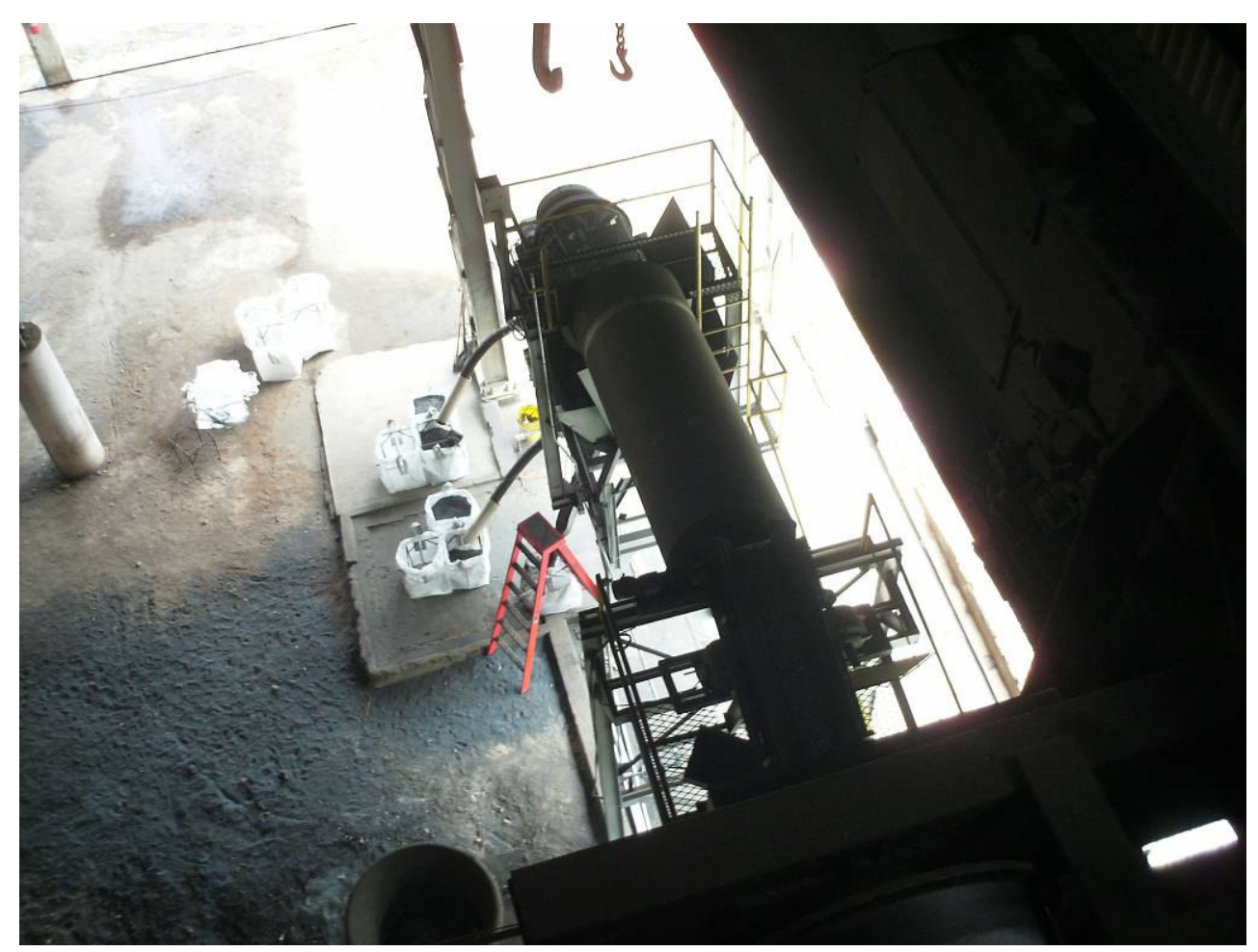

Figura 2.26 - Secagem e peneiramento de metal da Morro Azul.

\subsubsection{GRANULAÇÃO DE ESCÓRIA}

Assim como o metal, a escória é descarregada em temperaturas que normalmente pertencem ao intervalo 1480-1650 ำ (DOR; SKRETTING, 1979). Pode-se depositá-la a quente ou granulá-la. No caso da etapa de redução, os volumes de material são muito grandes, o que leva à decisão de escolher um local adequado para sua deposição. Devido à escassez de água, o projeto Onça Puma, por exemplo, optou por depositar a escória quente em um local apropriado, distante das edificações do forno. Isto levou à criação de uma logística complexa para o manejo de materiais nesta área.

Como padrão da indústria, normalmente a escória é granulada com água (em piscinas ou com jatos d'água a altas pressões), de forma a facilitar seu manejo ulterior. O transporte da escória granulada fria é feito por caminhões convencionais. Este sistema é indicado na figura 2.27. 


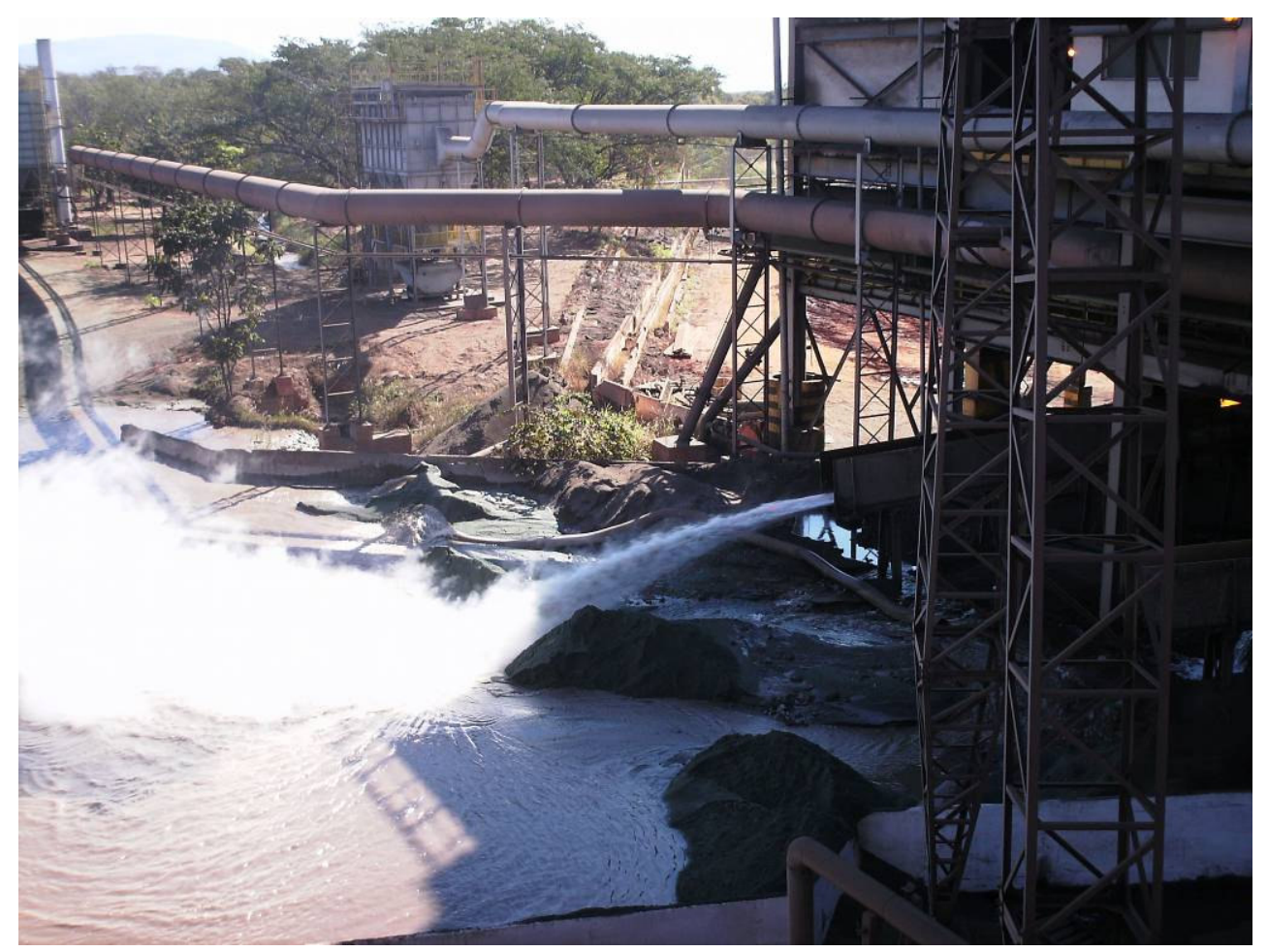

Figura 2.27 - Granulação de escória da etapa de redução da Codemin.

A escória do refino pode ser granulada ou resfriada de modo semelhante, conforme indicado na figura 2.28.

O refino depende fundamentalmente da experiência do operador, e conseqüentemente também a recuperação metalúrgica. Se a remoção de escória for feita de modo descuidado, provavelmente a escória conterá grandes quantidades de metal, o que resulta em prejuízo para a operação como um todo.

Pensando nisso, foi desenvolvida uma área de recuperação de metal (metal recovery), onde a escória do refino passa por tratamento físico e os fragmentos metálicos são recuperados e realimentados ao processo. 


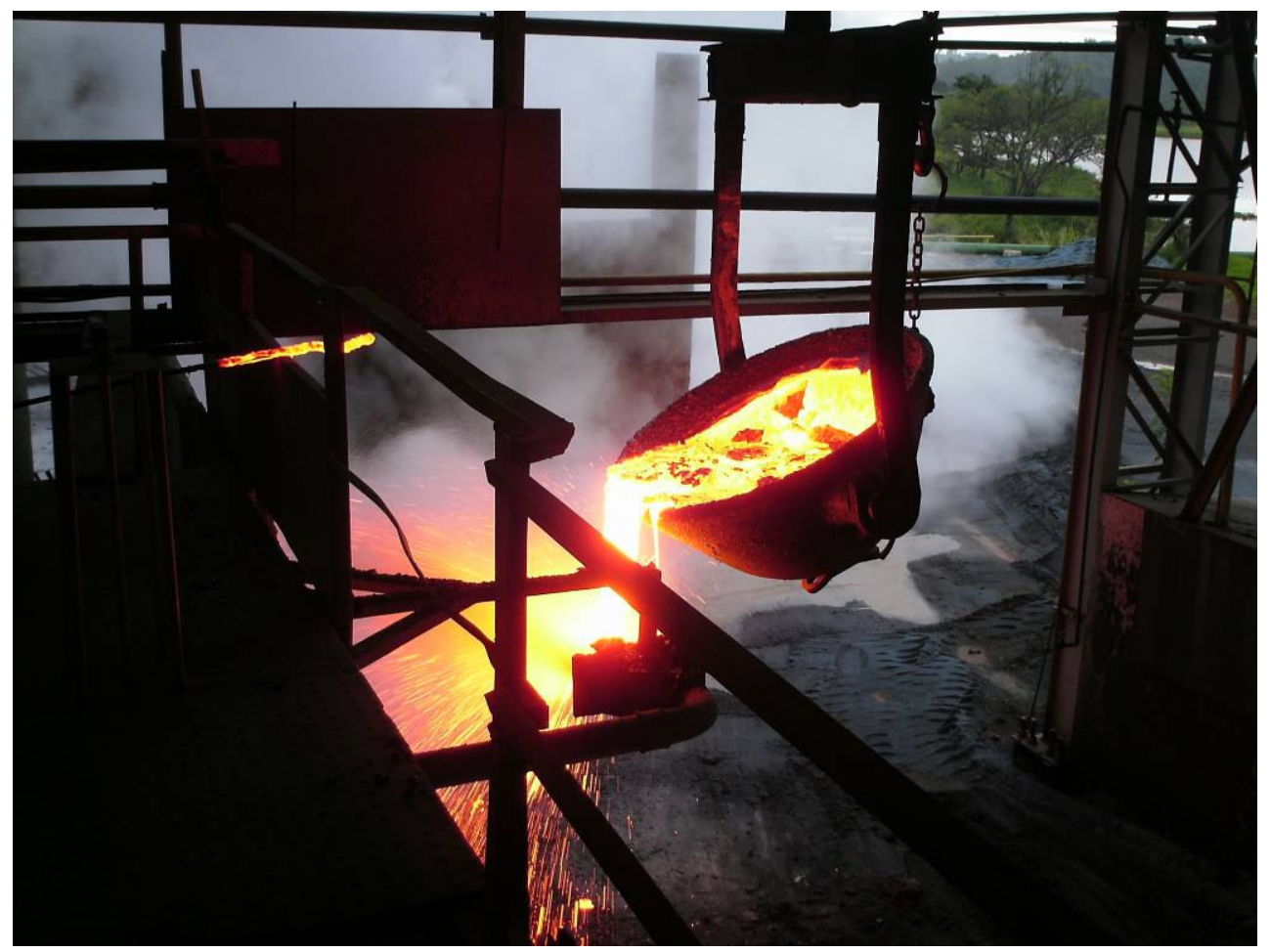

Figura 2.28 - Granulação de escória do refino da Morro Azul.

\subsubsection{PROCESSAMENTO DE ESCÓRIA DO REFINO}

Esta área da usina opera de maneira intermitente, visto que o processo de refino trabalha em bateladas e o desgaste de peças e refratários é intenso. Devido a estes motivos, normalmente os equipamentos são dimensionados para trabalharem apenas uma vez por semana. Tipicamente existem duas rotas de reprocessamento: a seco e a úmido. Independentemente de qual seja, as etapas de concentração são industrialmente feitas por separação magnética ou gravítica.

A rota de processamento a seco normalmente apresenta as seguintes operações unitárias principais:

- britagem em dois ou três estágios, ambos com britadores de mandíbulas primários e rolos únicos secundários e terciários. Etapas secundária e terciária operam em circuito fechado direto, com peneiras vibratórias de um ou dois decks;

- sistemas de despoeiramento para cada etapa de britagem, descarregando o pó coletado em caixas de finos ou caçambas tipo Brooks; 
- separação magnética a seco, onde o produto não magnético é descartado e o magnético é retornado ao processo, geralmente à estação de refino.

Este circuito, que se encontra indicado na figura 2.29, também recebe como materiais de reprocessamento refratários desgastados de panelas de refino e outros rejeitos de manutenção do forno elétrico e do calcinador. As carepas de maiores dimensões são separadas manualmente do restante do refratário.

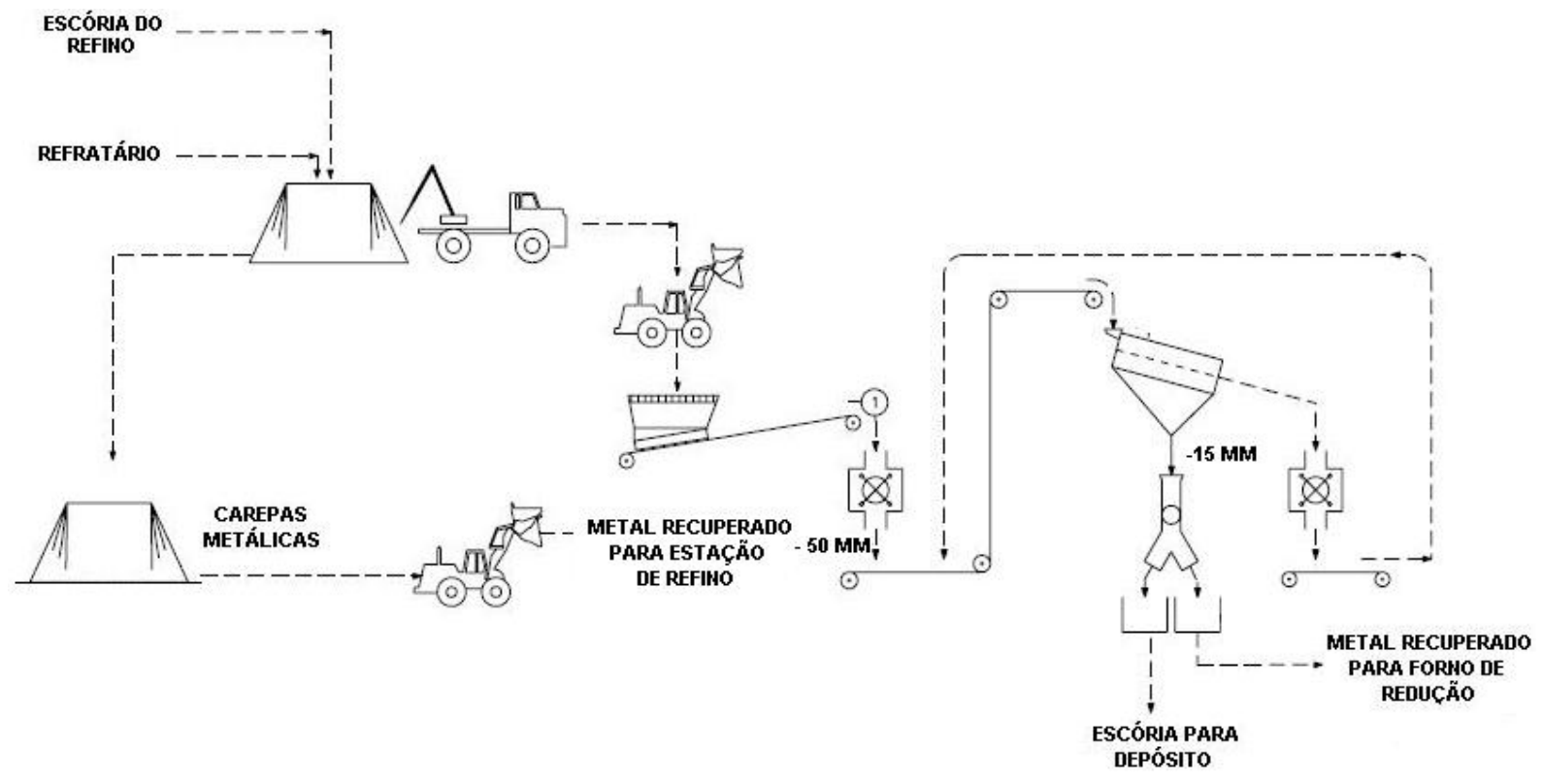

Figura 2.29 - Circuito de recuperação de metal a seco típico.

Já o circuito a úmido se utiliza de métodos gravíticos e se apresenta bastante distinto a este, como se observa pela descrição a seguir:

- britagem em um ou dois estágios, com britadores de mandíbulas e/ou rolos únicos, todos em circuito aberto;

- moagem em moinho de barras, a úmido, em circuito fechado com ciclone ou classificador espiral, ou ainda em circuito aberto;

- concentração gravítica por jigagem em dois estágios, onde o produto leve final é descartado e o produto pesado é secado sob o sol e realimentado ao forno de redução. 
Como cada usina possui seu circuito distinto, será feita uma abordagem focada na rota da Mineração Morro Azul, que será descrita no capítulo 3. 


\section{A MINERAÇÃO MORRO AZUL}

Este capítulo discorre sobre a Mineração Morro Azul e sua importância para este trabalho.

\subsection{LOCALIZAÇÃO E GEOLOGIA}

A região de Fortaleza de Minas é notoriamente conhecida pelo Cinturão VulcanoSedimentar Morro do Ferro. Importantes minerações se desenvolveram na região, principalmente a Mineração Serra da Fortaleza (antiga RTZ, hoje Votorantim) e a Morro do Níquel (antiga Anglo American). Os depósitos se localizam parcialmente no município de Fortaleza de Minas e parcialmente em Itaú de Minas, conforme as figuras 3.1 e 3.2 .

Depois de um estudo de viabilidade positivo e sucessivos estudos de engenharia, a Mineração Morro do Níquel foi construída e iniciou suas operações em 1962, com duas linhas de produção e capacidade para 2.500 t/ano de níquel contido no ferroníquel (DALVI; BACON; OSBORNE, 2004). A Morro foi fechada em 1998, devido aos baixos preços do níquel no mercado e à exaustão das reservas. 


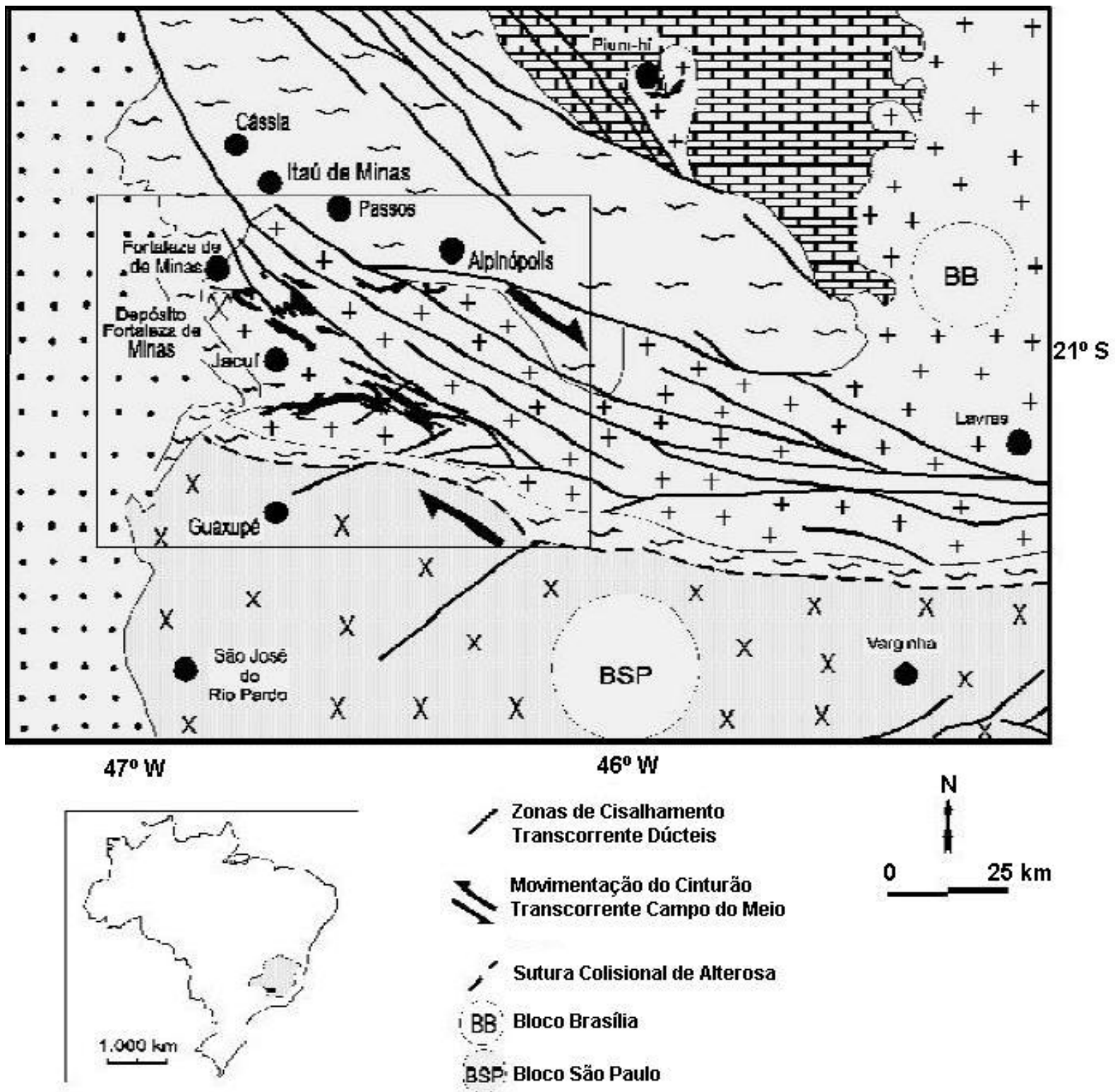

\begin{tabular}{|c|c|c|c|}
\hline FANEROZÓICO & $\because \because$ & $\begin{array}{l}\text { Coberturas sedimentares } \\
\text { e sills de diabásio }\end{array}$ & I BACIA DO PARANÁ \\
\hline NEO-PROTEROZÓICO & 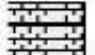 & Grupo Bambuí & | FAIXA BRASÍLIA \\
\hline MESO-PROTEROZÓICO & & Grupos Araxá e Canastra & I FAIXA BRASÍLIA \\
\hline \multirow[t]{2}{*}{ ARQUEANO } & & $\begin{array}{l}\text { Complexo Barbacena, com } \\
\text { sequiências metavulcano- } \\
\text { sedimentares tipo } \\
\text { greenstone belt }\end{array}$ & IERRENOS GRANITO-GREENSTONE \\
\hline & $x$ & $\begin{array}{l}\text { Complexo Varginha } \\
\text { e Grupo Caconde }\end{array}$ & $\begin{array}{l}\text { TERENOS DE ALTO GRAU } \\
\text { CINTURÃO GRANULÍTICO ALFENAS }\end{array}$ \\
\hline
\end{tabular}

Figura 3.1 - Macrolocalização do Morro do Ferro (adaptado de FERNANDES et al., 2003). 


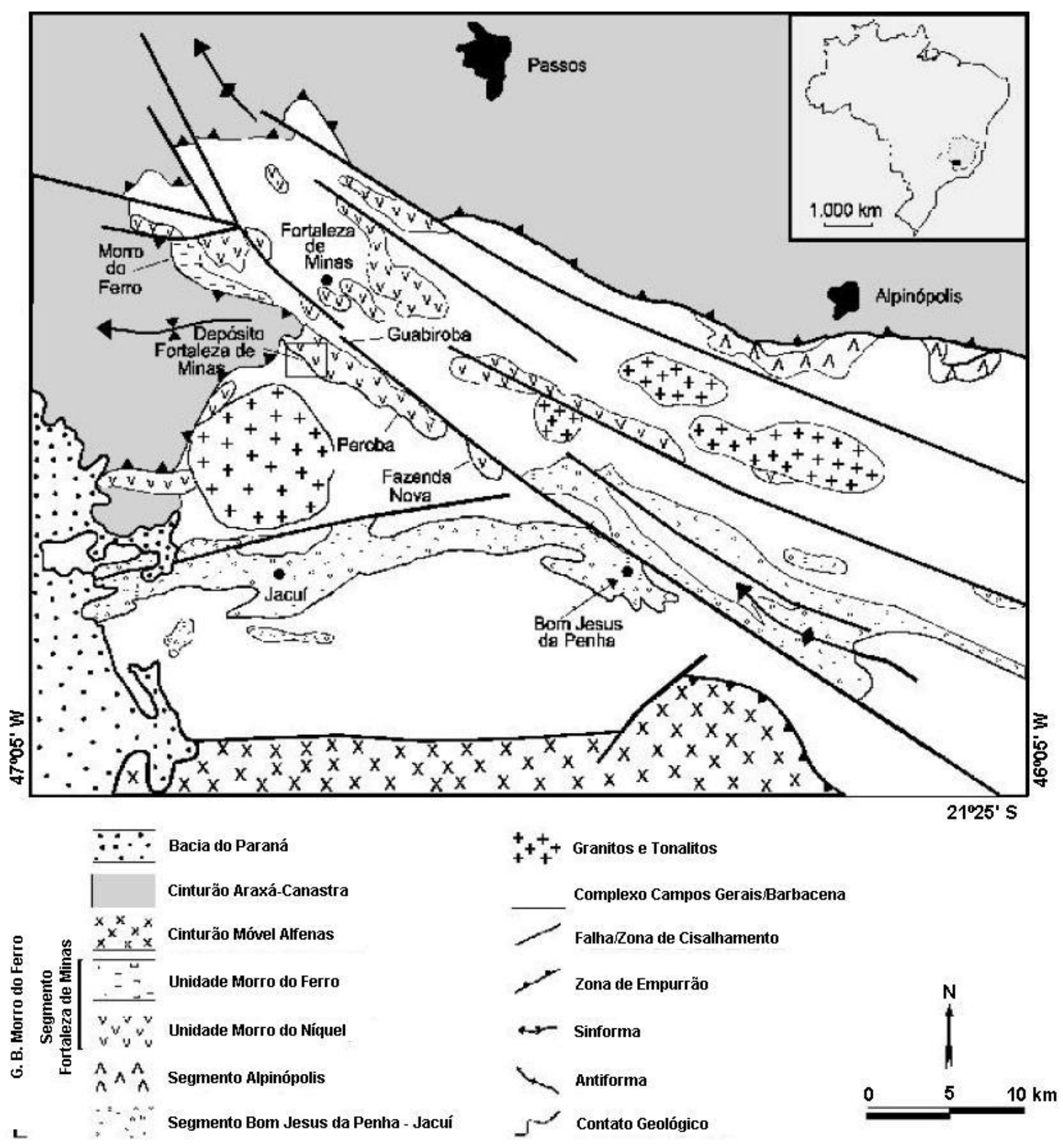

Figura 3.2 - Microlocalização do Morro do Ferro (adaptado de FERNANDES et al., 2003).

\subsection{USINA}

A Mineração Morro do Níquel permaneceu fechada até o ano de 2006, quando foi vendida para um grupo independente. Rebatizada de Morro Azul, reiniciou suas operações em 2007, na linha 1 apenas. Os refratários da carcaça do forno de redução foram substituídos e equipamentos de britagem foram adicionados. $A$ 
nova usina produz hoje 4 corridas de metal de 8 t cada no período diurno, processadas no antigo conversor LD - não foi necessário reativar o forno elétrico de refino existente. Hoje, são realizadas as seguintes etapas de processo:

- Britagem a $30 \mathrm{~mm}$ do minério misturado com o pó em dois estágios, um com britador de mandíbulas e outro com britador cônico. A britagem secundária opera em circuito aberto com escalpe anterior ao britador cônico (alteração implantada em janeiro de 2009);

- Mistura do redutor (madeira picada) ao minério em tambor rotativo;

- Calcinação em forno rotativo a óleo, de 2,6 m de diâmetro por $57 \mathrm{~m}$ de comprimento, cujo pó é coletado e realimentado ao processo;

- Redução em forno elétrico de 4,8 MW;

- Refino em conversor LD (com unidade reserva), onde são realizadas etapas de dessulfuração (de-S), descarburetação (de-C), dessilicização (de-Si) e desfosforização (de-P);

- Granulação de escória do refino, com reprocessamento ulterior;

- Granulação de ferroníquel refinado em tanque com água;

- Secagem, peneiramento, ensacamento e expedição do produto final.

O metal quente retirado do forno elétrico é transportado até o conversor e a ele transferido. O conversor é então iniciado e um sopro de oxigênio é feito. São feitas adições de madeira e cal como agentes reativo e formador de escória, respectivamente, além de sucata e metal reciclado. Cada escória é retirada manualmente com um rastelo e derramada sobre um pote, que é levado à granulação. As fotos 3.3 a 3.5 ilustram o processo.

A escória do refino contém mais níquel que a escória do forno de redução. Por este motivo, a cultura industrial desenvolveu rotas de reprocessamento desta escória para recuperação do metal contido. Este tema será discutido com maior profundidade a seguir. 


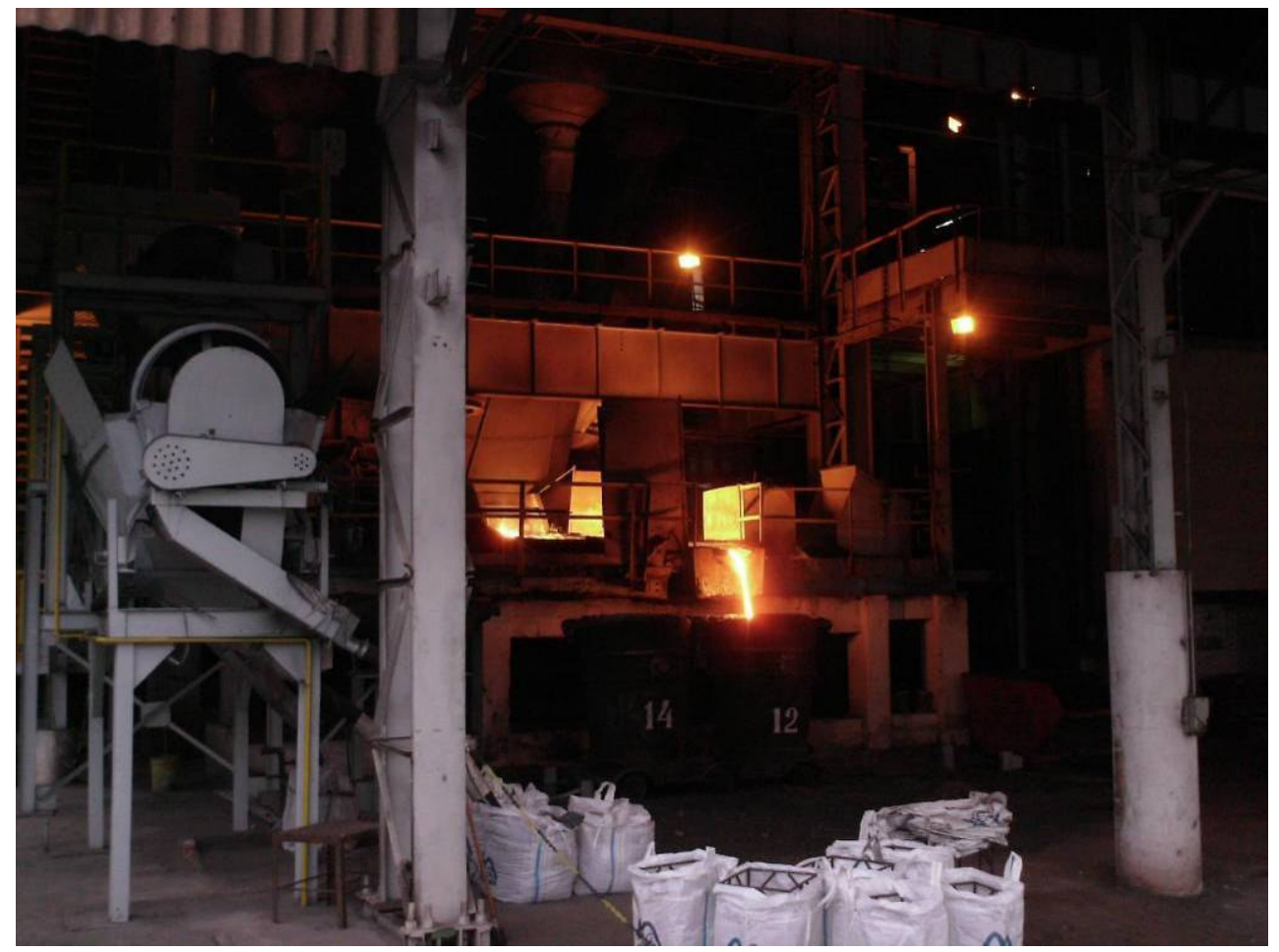

Figura 3.3 - Corrida de metal do forno, com peneira de ferroníquel à esquerda.

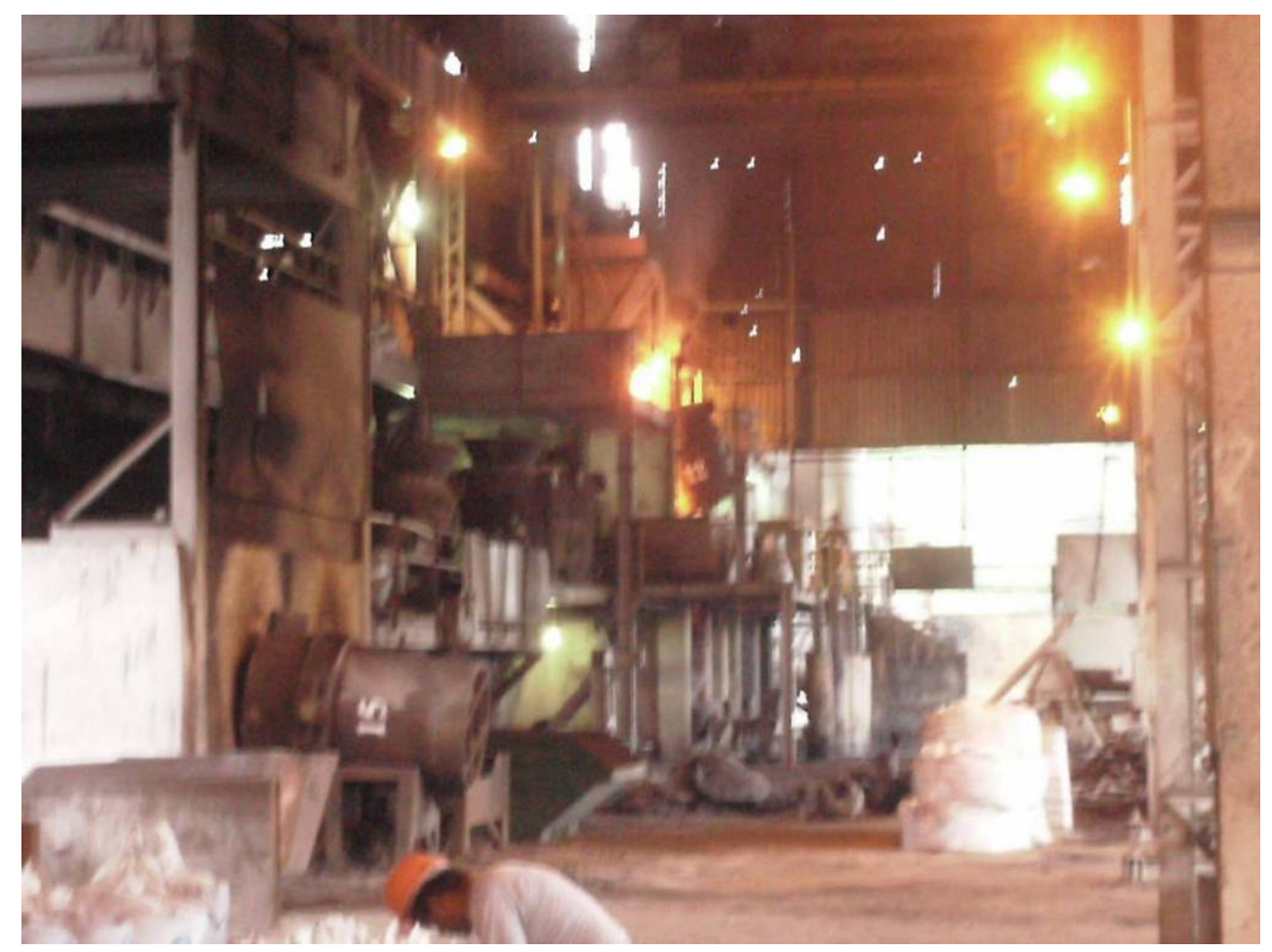

Figura 3.4 - Transferência de metal da panela para o conversor ao fundo, com estação de pré-aquecimento à frente e à esquerda. 


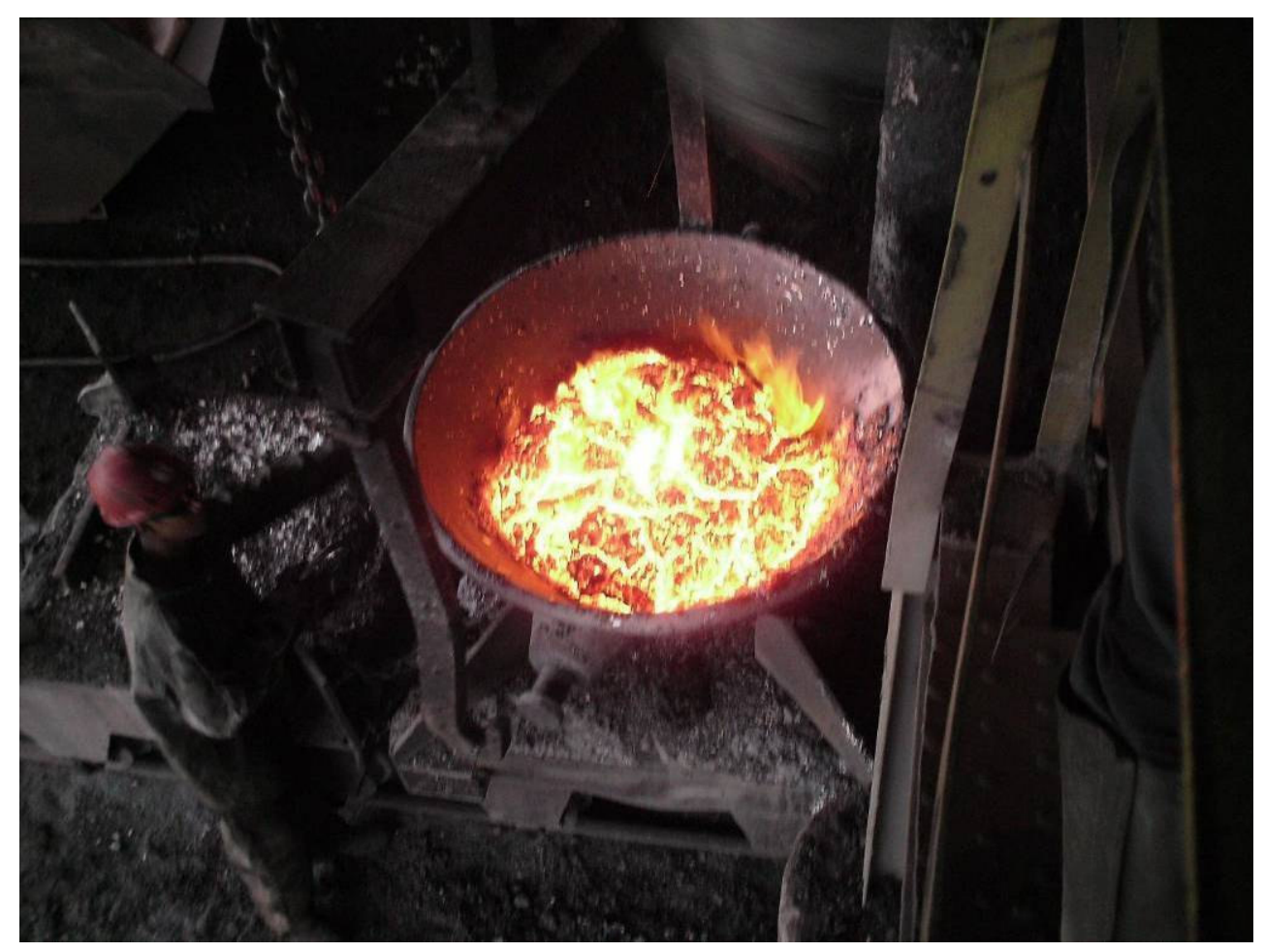

Figura 3.5 - Escória retirada do conversor.

\subsection{RECUPERAÇÃO DE METAL}

Esta área da usina opera de maneira intermitente, pelos motivos já expostos neste trabalho. O circuito da Morro, ilustrado nas figuras 3.7 e 3.8, apresenta-se da seguinte maneira:

- britagem em dois estágios, com britador primário de mandíbulas e secundário de impacto, ambos em circuito aberto;

- moagem em moinho de barras a úmido, em circuito aberto;

- concentração gravítica por jigagem em dois estágios, onde o produto leve final é descartado e o produto pesado primário é secado ao tempo e realimentado ao forno de redução. 


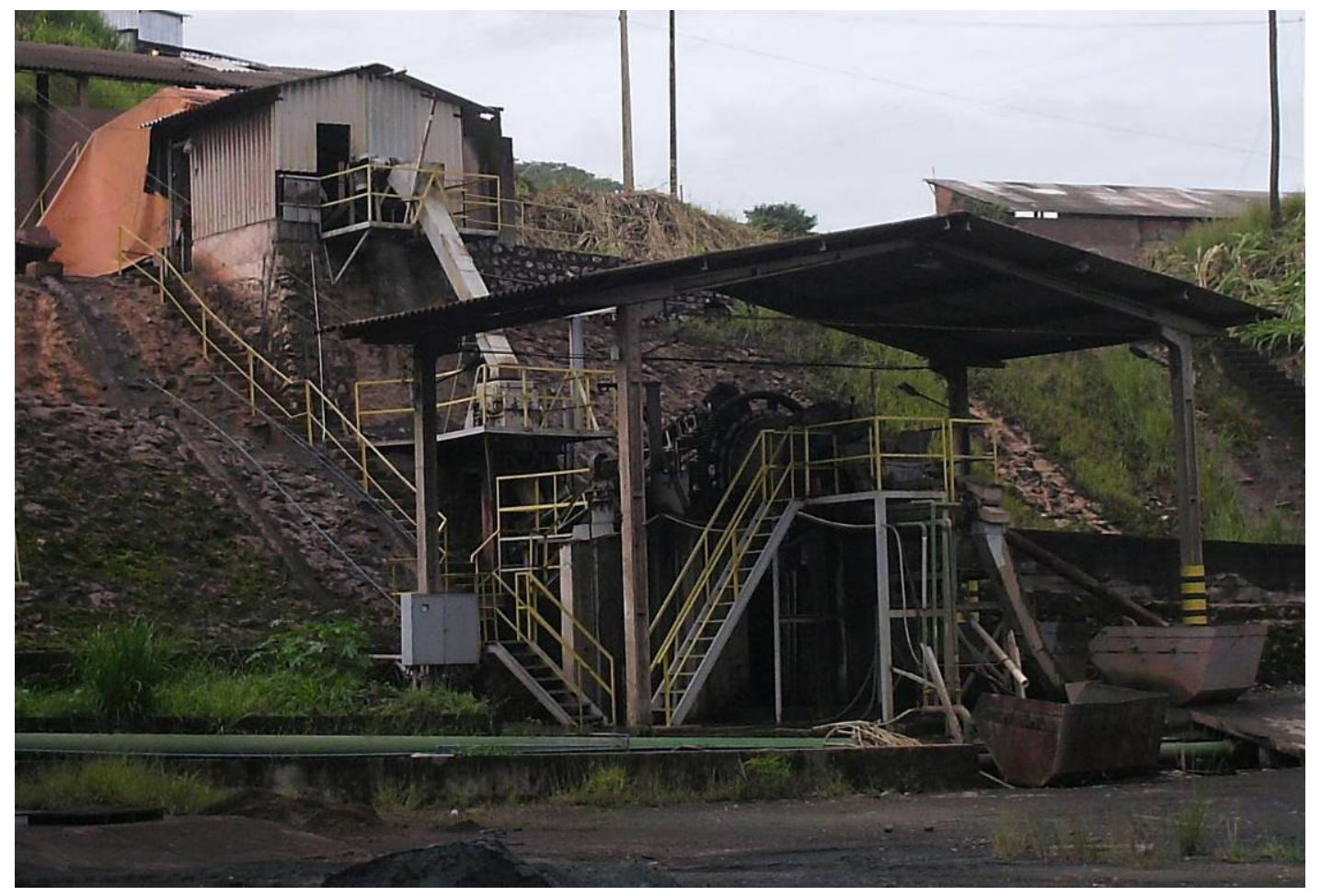

Figura 3.6 - Vista da usina de recuperação de metal, com a britagem primária no ponto mais alto e a secundária no patamar intermediário, antes da moagem.

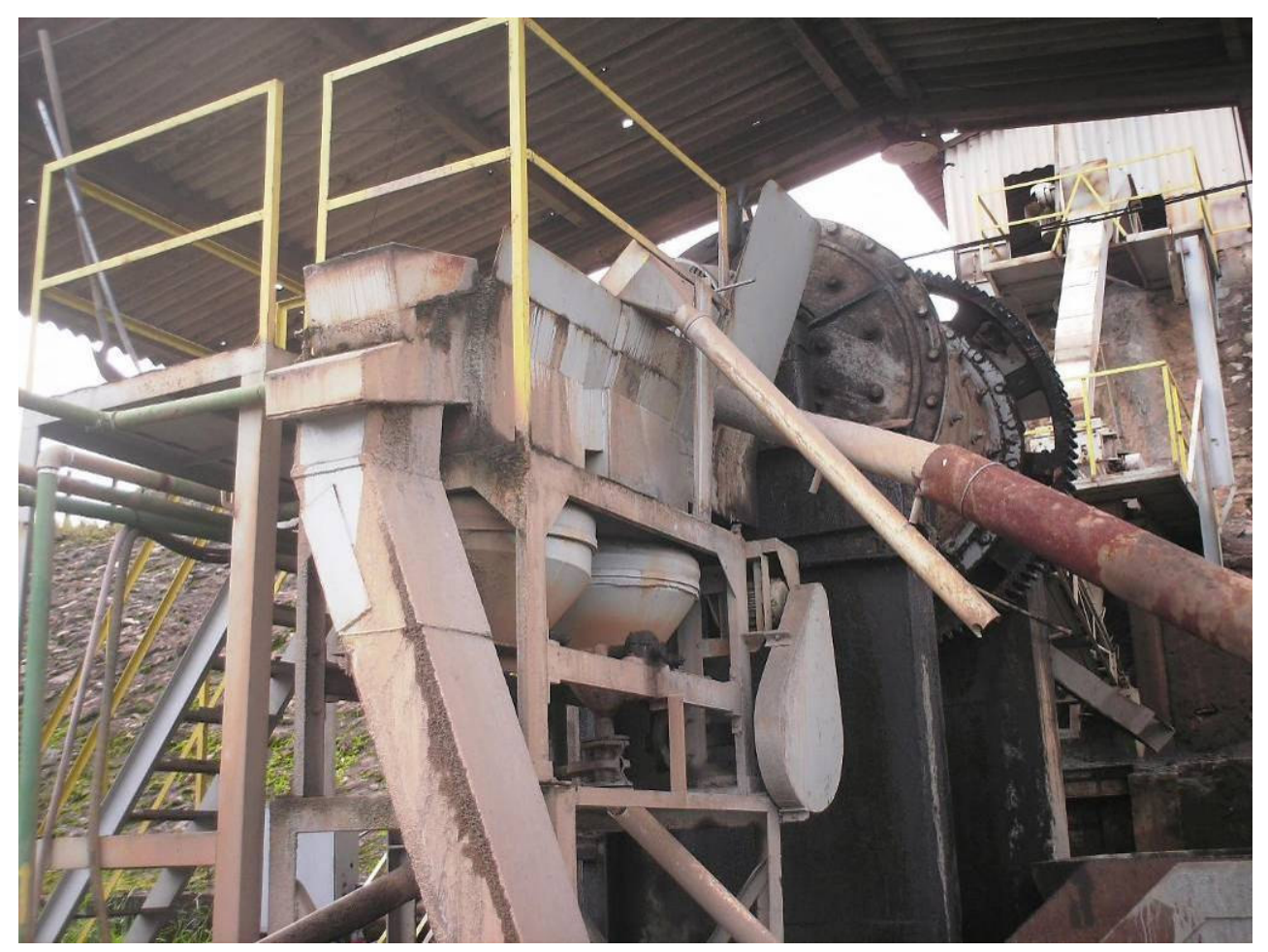

Figura 3.7 - Vista do piso baixo da moagem, com a jigagem à frente. 
A descarga do trommel necessita ser inspecionada visualmente antes de ser retornada ao moinho. Dependendo da maneira como o refino é operado, podem se formar pequenos "bolsões" de metal que ficam envolvidos pela escória. No ato da cominuição, como não são britáveis, esses fragmentos agora solidificados devem ser eliminados do circuito rapidamente, ou os equipamentos do circuito podem não funcionar de maneira adequada.

Outra questão importante é que nem toda a escória é granulada. Ainda restam alguns fragmentos de escória resfriada que, uma vez solidificada, dificulta 0 processo de cominuição, pois apresenta um WI muito alto (em torno de $20 \mathrm{kWh} / \mathrm{st}$ ). Esta questão foi discutida na coleta de amostras e no planejamento dos trabalhos de pesquisa.

Cabe aqui ressaltar que mundialmente existe uma preferência por circuitos de cominuição a úmido, pelas seguintes vantagens (CHAVES; PERES, 2006):

- Menor consumo energético;

- Dissipação do calor gerado na moagem;

- Maior homogeneidade do produto;

- Menor desgaste;

- Manuseio de materiais simplificado, pela facilidade de transporte da polpa;

- Necessidade de sistemas de despoeiramento eliminada.

Adicionalmente, informações coletadas de visitas técnicas demonstram que as recuperações metalúrgicas das usinas costumam ultrapassar os $93 \%$ quando o processamento de escória está implantado - normalmente permanecem abaixo de $90 \%$.

Por estes motivos, optou-se por estudar possíveis variantes deste circuito (a úmido) e indicar medidas técnicas para aumentar a disponibilidade da instalação e facilitar a operação da planta. 


\section{MATERIAIS E MÉTODOS}

De forma a atingir os objetivos propostos por este trabalho, realizou-se uma visita à Mineração Morro Azul. Coletaram-se cerca de $200 \mathrm{~kg}$ de escória granulada e $200 \mathrm{~kg}$ de escória resfriada, amostras que foram enviadas ao Laboratório de Simulação e Controle de Processos (LSC) do Departamento de Engenharia de Minas e de Petróleo da Escola Politécnica da USP. Os procedimentos realizados com cada uma são descritos neste capítulo.

\subsection{CARACTERIZAÇÃO FíSICA}

As amostras foram recebidas e armazenadas em abrigo coberto. Posteriormente, cada escória foi processada conforme o fluxograma indicado na figura 4.1.

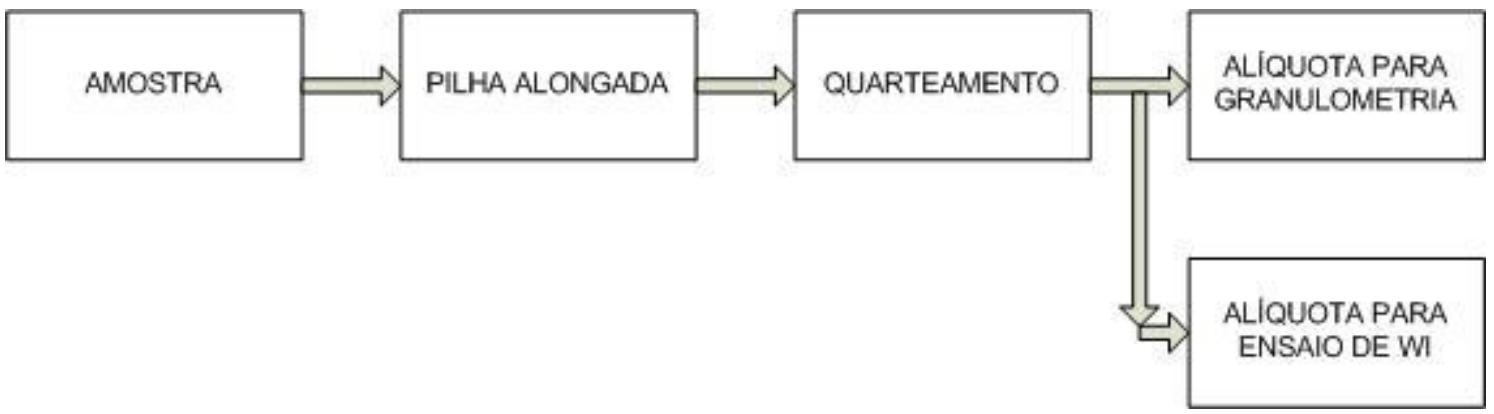

Figura 4.1 - Preparação de alíquotas para determinação de granulometria.

As alíquotas reservadas para cada ensaio estão indicadas na tabela 4.1.

Tabela 4.1 - Alíquotas para caracterização física.

\begin{tabular}{|c|c|c|}
\hline Tipo de Escória & Granulometria & WI \\
\hline Resfriada & $30,4 \mathrm{~kg}$ & $18,5 \mathrm{~kg}$ \\
\hline Granulada & $10,3 \mathrm{~kg}$ & $21,8 \mathrm{~kg}$ \\
\hline
\end{tabular}

Uma vez com a análise granulométrica feita, cada alíquota de amostra sofreu o procedimento de preparação indicado na figura 4.2. Depois de recomposta, cada 
alíquota foi peneirada em 6,73 $\mathrm{mm}$ e o retido sofreu britagem. Depois de britado, o material foi novamente peneirado e o grosso britado, até que todo o material passasse. Posteriormente, foi feita uma pilha alongada e o quarteamento da mesma.

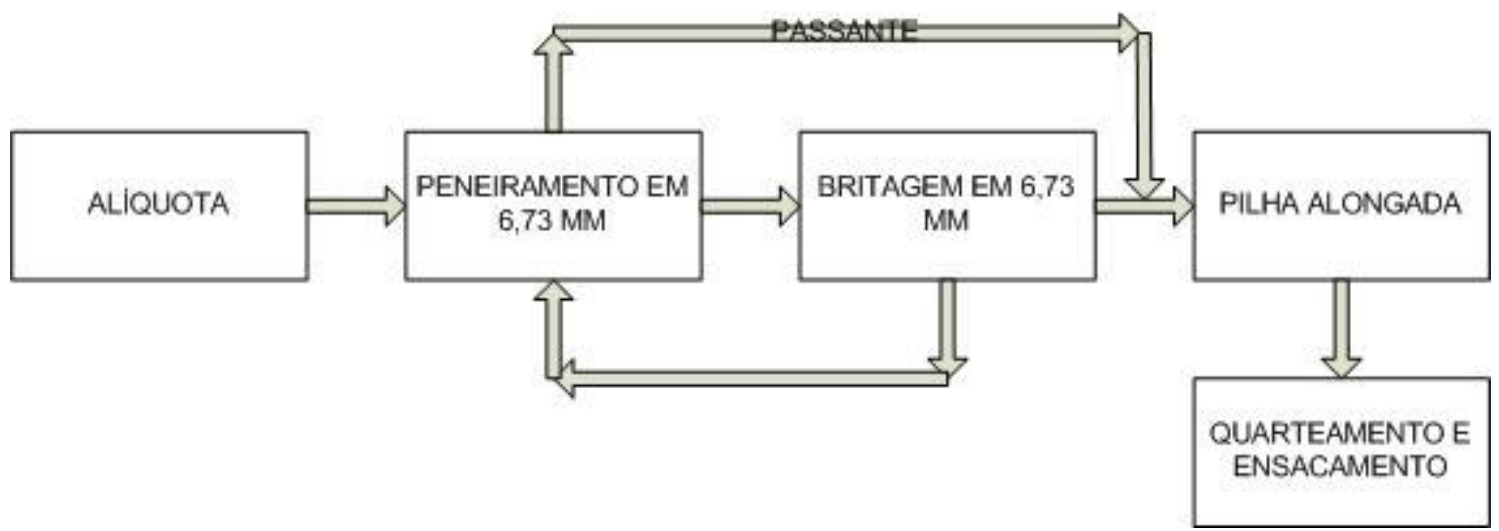

Figura 4.2 - Britagem de alíquotas.

Conforme a necessidade, cada subalíquota foi moída em moinho de barras, por procedimento análogo à britagem, de acordo com a figura 4.3.

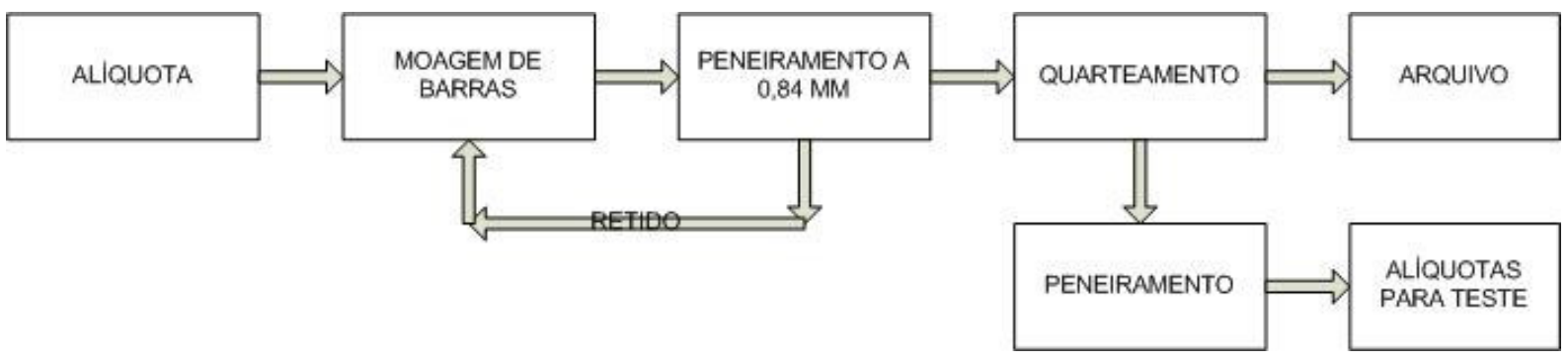

Figura 4.3 - Moagem de alíquotas.

Foram então separadas as alíquotas para os seguintes testes:

- granulometria de cabeça;

- determinação de WI;

- microscopia eletrônica de varredura;

- separação com líquido denso; e

- concentração em mesa Mozley. 
A distribuição desses ensaios por amostra encontra-se indicada na tabela 4.2.

Tabela 4.2 - Testes realizados com cada escória.

\begin{tabular}{|c|c|c|c|c|c|}
\hline Escória & Granulometria & WI & Mesa Mozley & Líquido Denso & MEV \\
\hline Resfriada & $\mathrm{X}$ & $\mathrm{X}$ & & & $\mathrm{X}$ \\
\hline Granulada & $\mathrm{X}$ & $\mathrm{X}$ & $\mathrm{X}$ & $\mathrm{X}$ & $\mathrm{X}$ \\
\hline
\end{tabular}

Os procedimentos utilizados para estes testes são descritos a seguir.

\subsubsection{BRITAGEM}

$\mathrm{Na}$ britagem, foi utilizado um britador de rolos modelo MR2515 da Furlan de 450 kg, com dois motores de $3 \mathrm{hp}$ e rotação de 350 rpm, mostrado na figura 4.4.

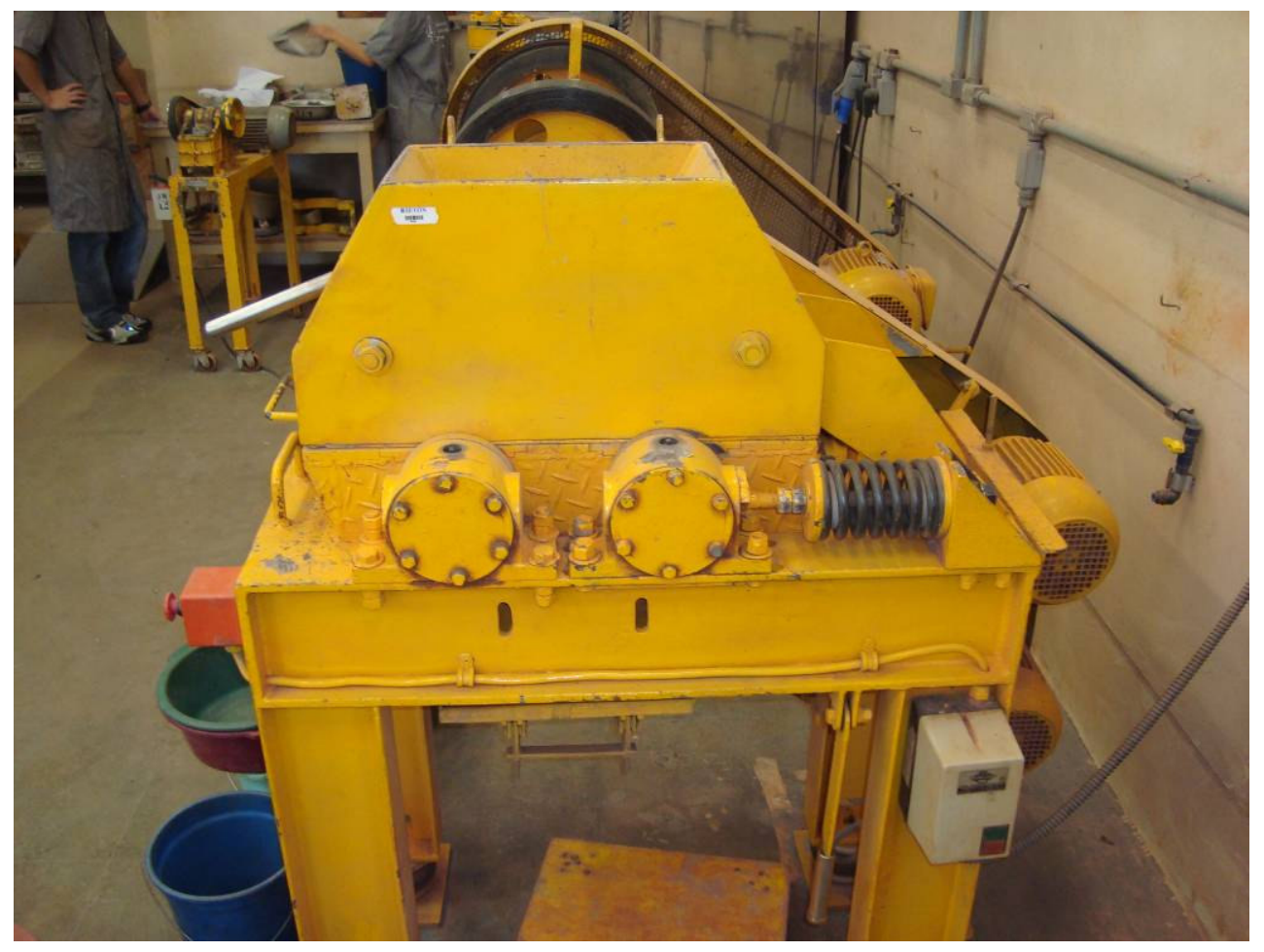

Figura 4.4 - Britador de rolos utilizado nos trabalhos. 
O procedimento era realizado da seguinte maneira. O material era escalpado na malha de teste. A fração grossa era enviada ao britador, enquanto que a fina era armazenada para uso posterior. O produto do britador retornava à peneira, até que $100 \%$ da massa passasse pela peneira.

\subsubsection{MOAGEM}

As amostras foram moídas em moinho tubular de barras, por batelada, com acionamento externo por rolos revestidos de borracha, provendo ao moinho a velocidade de $70 \mathrm{rpm}$, conforme figura 4.5 .

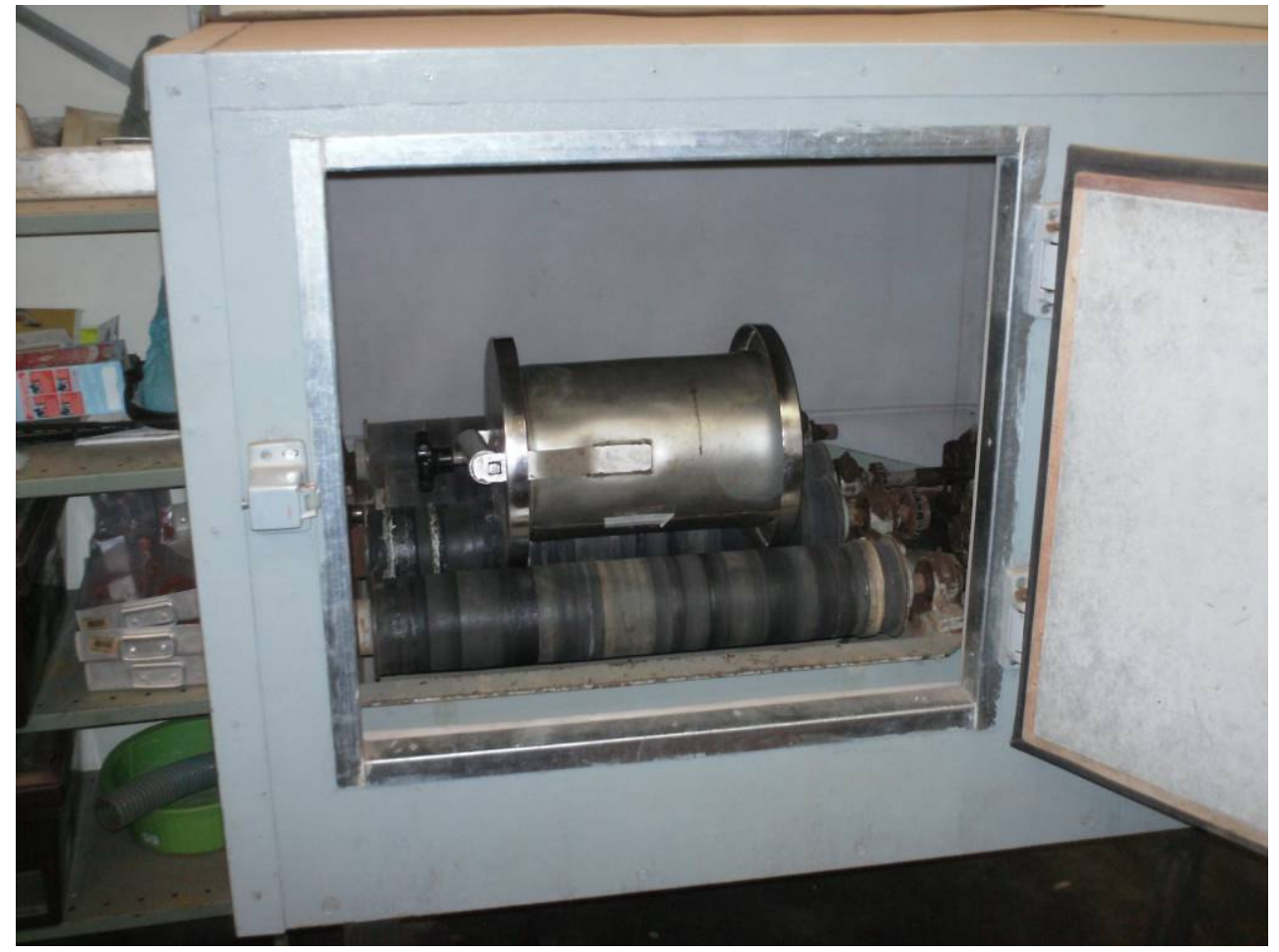

Figura 4.5 - Moinho de barras utilizado nos trabalhos.

O procedimento de controle de malha utilizado foi idêntico ao da britagem. 


\subsubsection{PENEIRAMENTO}

Todo o peneiramento de amostras foi realizado a seco, com peneiras de laboratório e um vibrador suspenso. O jogo de peneiras seguia a série ASTM de malhas. O tempo de peneiramento foi de 20 minutos em todos os casos.

\subsubsection{DETERMINAÇÃO DE WI}

O procedimento utilizado para determinação de WI é padrão para toda a indústria. Foi desenvolvido por Fred Bond, em 1952, e modificado em 1961 (BOND, 1961; LEVIN, 1989). Inicialmente, é necessário preparar uma quantidade de material, que varia entre 10 e 20 kg, para que sua distribuição granulométrica seja 100\% 3,36 mm. Feito isto, faz-se uma pilha alongada com o material e são determinados ou definidos os seguintes parâmetros de teste:

- malha do teste: $0 \mathrm{P}_{80}$ do teste;

- massa específica aparente do material, determinada a partir da massa contida no volume padrão de $3000 \mathrm{~cm}^{3}$;

- carga do moinho, em g; e

- $\quad$ massa de produto do período ideal, ou ideal period product (IPP), em g.

O moinho utilizado é padrão, possui 12" $(30,5 \mathrm{~cm})$ de diâmetro por 12" $(30,5 \mathrm{~cm})$ de comprimento, volume de $700 \mathrm{~cm}^{3}$. Seu interior possui revestimento liso e carga de bolas de $20.125 \mathrm{~g}$ de distribuição específica para o teste. O moinho deverá girar a uma velocidade de aproximadamente $70 \mathrm{rpm}$. O equipamento pode ser observado na figura 4.6 .

Para a realização do teste, é necessário calcular os parâmetros iniciais. Uma alíquota é então retirada da pilha e sua distribuição granulométrica é determinada. A partir desta, determina-se o parâmetro $K$, que é a fração passante na malha do teste. Posteriormente, pesa-se um volume padrão de $3000 \mathrm{~cm}^{3}$ cheio de material, o que permite obter a massa específica aparente a partir da seguinte equação: 


$$
\gamma_{a p}=\operatorname{mass} a^{*} 22,046
$$

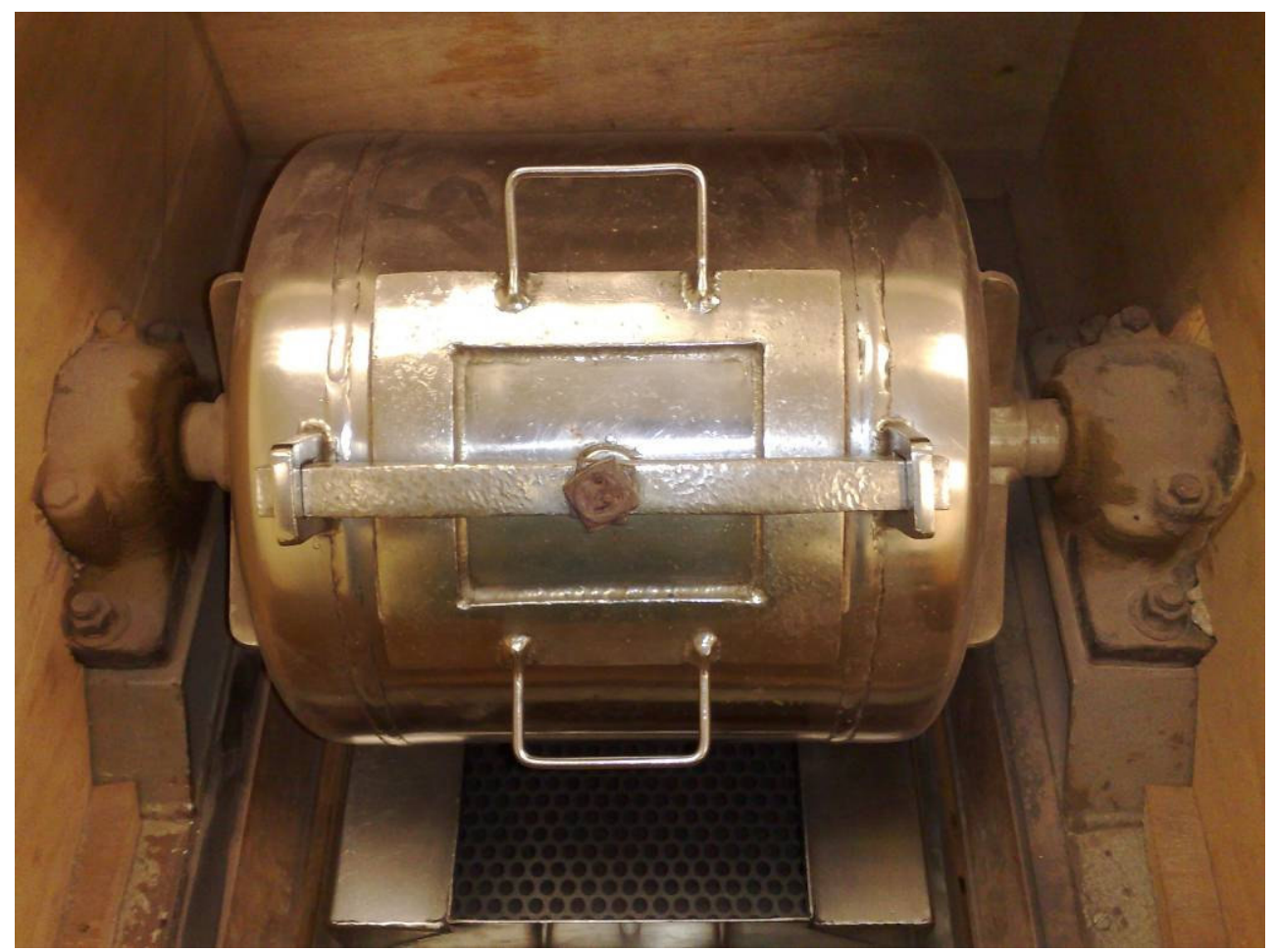

Figura 4.6 - Moinho padrão para teste de WI.

A partir da massa específica aparente, determina-se a carga do moinho, de acordo com a eq. (18).

$$
C=\gamma_{a p} * 11,218
$$

Uma vez determinada a carga do moinho, determina-se o IPP:

$$
I P P=\frac{C}{3,5}
$$

Para o início dos testes, são determinadas as massas retida e passante na malha de teste, assim como o cálculo do produto já presente na carga. Feitas essas determinações, faz-se a carga inicial do moinho com a massa determinada na eq. (20). O moinho é então ligado, ajustando-se o contador de rotações para 100. Findo o ciclo de moagem, o material é retirado do moinho, os corpos moedores são retornados ao seu interior e o material é peneirado na malha de teste. São 
registradas as massas retida e passante, e é calculado o produto líquido por rotação, de acordo com a eq. (20):

$$
V=\frac{U}{Q}
$$

A massa passante é armazenada. A diferença para complementação da carga é adicionada e todo o material retorna ao moinho. Utilizando-se do produto líquido por rotação obtido, é realizado o cálculo do novo número de rotações a partir da eq. (21):

$$
Q=\frac{I P P-(R * K)}{V}
$$

O procedimento é então repetido até que $Q$ e $V$ tenham se estabilizado por três ciclos consecutivos. Isto resultará no seguinte:

- a massa retida na malha do teste será de igual valor ao IPP; e

- a carga circulante será igual a $250 \%$.

Neste momento, são realizados peneiramentos da carga circulante e do produto final, e o valor de $\mathrm{Y}$ é determinado (numericamente igual a $\mathrm{V}$, para estabilização em 3 ciclos). Assim, calcula-se o WI de acordo com a eq. (22):

$$
W I=\frac{44,5}{M^{0,23} * Y^{0,82} * 10\left(P^{-0,5}-F^{-0,5}\right)}
$$

Neste trabalho, foram determinados os WIs da escória granulada e da resfriada.

\subsection{CARACTERIZAÇÃO DE PROCESSO}

De acordo com BURT (1984), há possibilidade de separação de materiais contendo metais não-ferrosos com o auxílio do líquido denso. Já KELLY; SPOTTISWOOD (1982) mencionam o uso desta técnica na caracterização de materiais sensíveis a processos de concentração gravítica. Com isto em mente, foram realizados ensaios com líquido denso com a escória granulada. Estes encontram-se descritos no capítulo 5. 
Para a caracterização de processo propriamente dita, foram realizados ensaios de concentração em mesa Mozley. O equipamento pode ser observado na figura 4.7.

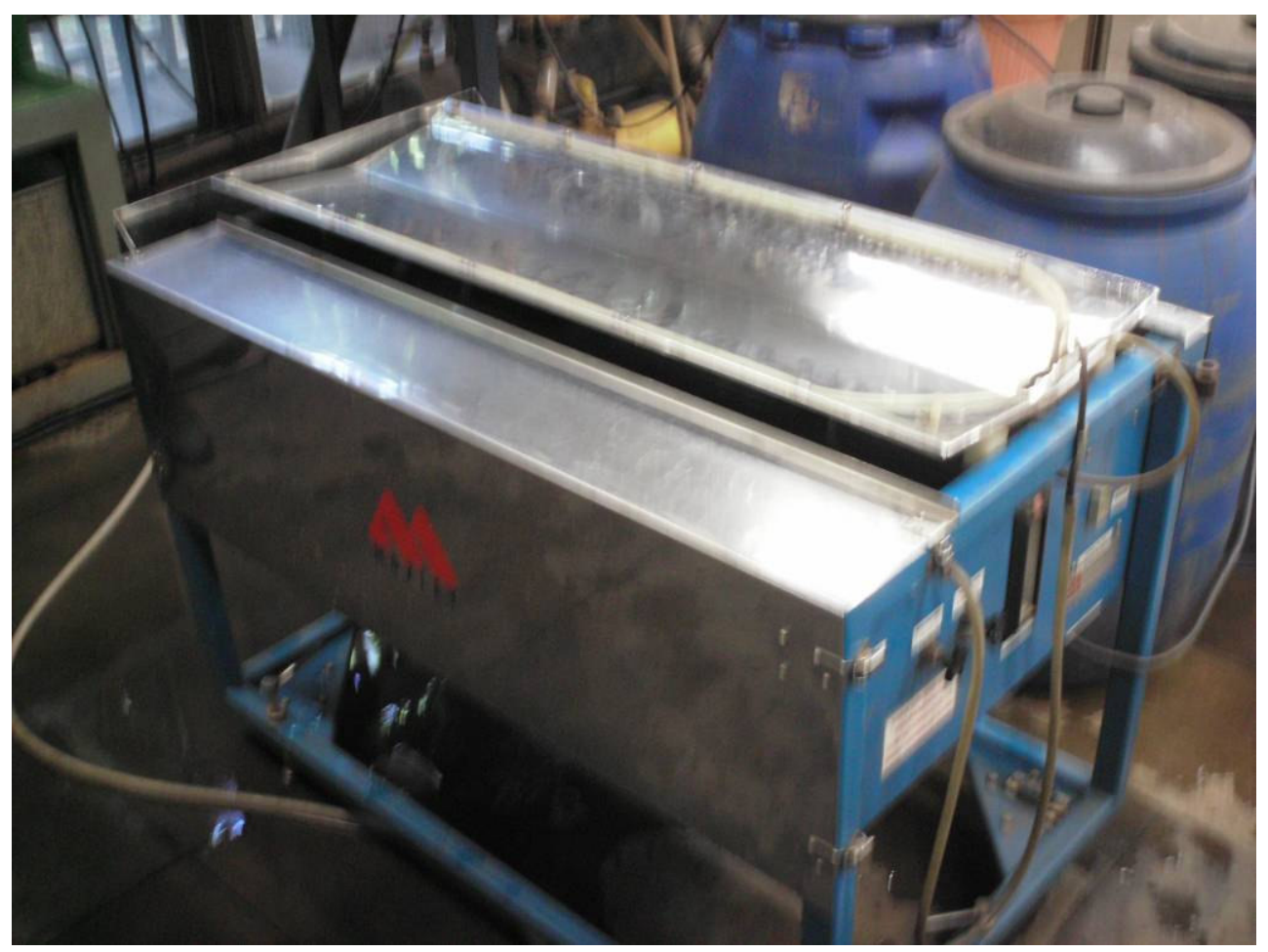

Figura 4.7 - Mesa Mozley utilizada nos ensaios.

O equipamento consiste de uma superfície inclinada em forma de "V", com descarga única. O material é disposto sobre a mesa em bateladas, na ponta localizada à direita da figura. Água é alimentada neste ponto, assim como ao longo das laterais, em jatos perpendiculares ao "V" da mesa. A superfície sofre uma oscilação frontal e lateral a partir da alimentação, cujo movimento lembra muito o de uma bateia. A água arrasta os materiais leves para a descarga, enquanto os pesados permanecem próximos à alimentação. Após tempo suficiente, a mesa é desligada, a descarga é lavada para a retirada do flutuado e, por último, retira-se o afundado pela mesma saída. Estes ensaios também encontram-se descritos no capítulo 5. 
Finalmente, os produtos de cada uma das frações sofreram separação magnética em bancada, para verificar a recuperação de metais diretamente da escória e compará-la com a dos óxidos. Esta etapa de separação magnética e análise química dos produtos finais também encontra-se descrita no capítulo 5 .

\subsection{CARACTERIZAÇÃO QUÍMICA}

Neste trabalho, foram realizadas analises químicas por via úmida em todas as frações obtidas a partir dos ensaios de concentração. Foram também realizadas análises por fluorescência de raios-X em duas amostras cabeça, uma de cada escória, em conjunto com microscopia eletrônica de varredura. 


\section{RESULTADOS}

As escórias granulada e resfriada podem ser observadas nas figuras 5.1 e 5.2, respectivamente.

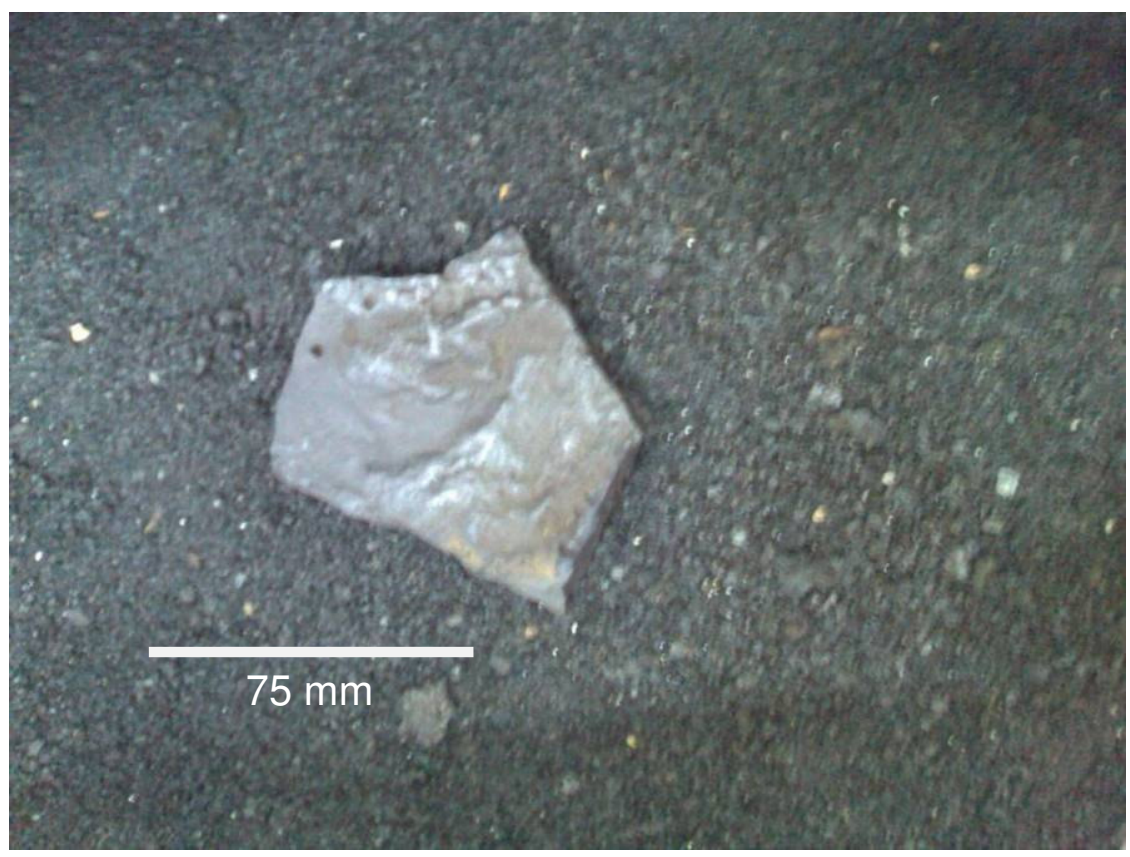

Figura 5.1 - Escória granulada tal qual, com escória resfriada como escala.

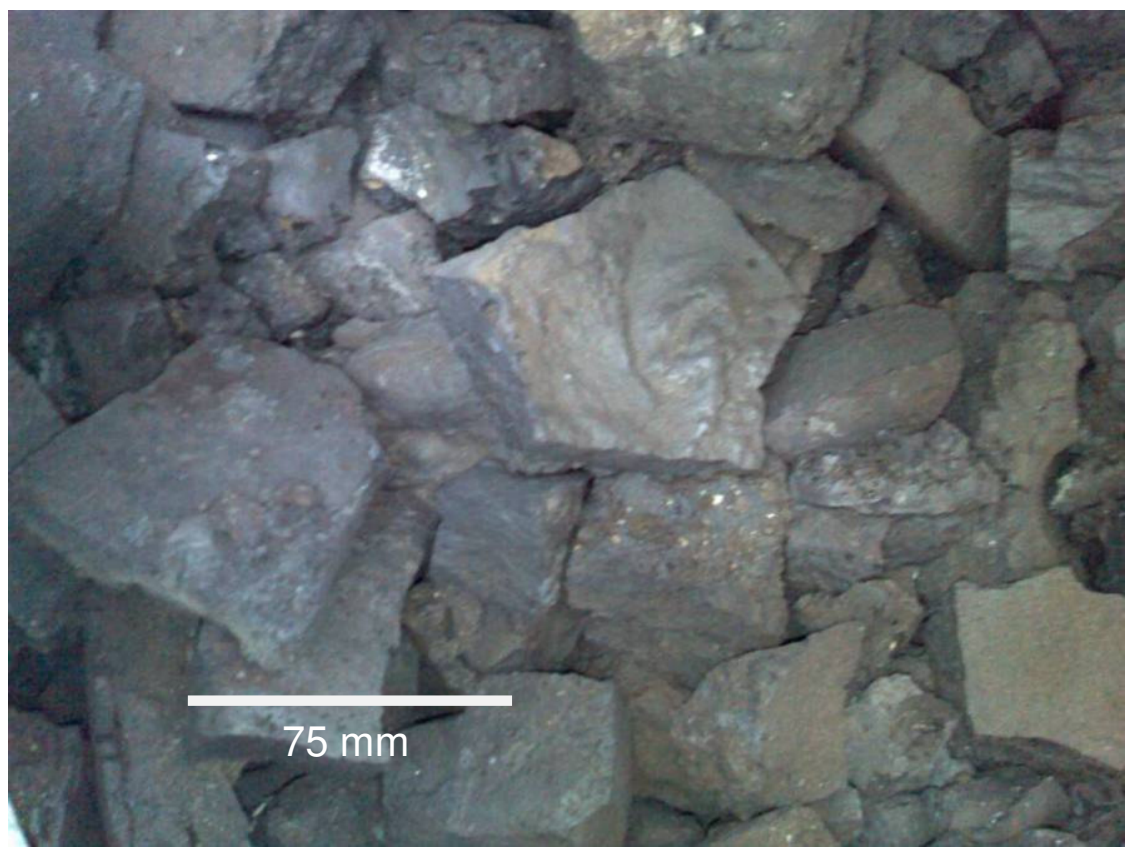

Figura 5.2 - Escória resfriada tal qual. 
Para fins de comparação entre as mesmas, a escória granulada e a resfriada foram ensaiadas de forma independente durante o desenvolvimento do trabalho, onde foi possível.

\subsection{PENEIRAMENTO "TAL QUAL"}

Uma alíquota de cada escória foi pesada e peneirada a seco até 100\#, tamanho a partir do qual foi realizado peneiramento a úmido. Os resultados obtidos são indicados nas tabelas 5.1 e 5.2 e nas figuras 5.3 e 5.4 .

Tabela 5.1 - Distribuição granulométrica da escória granulada tal qual.

\begin{tabular}{|c|c|c|c|c|}
\hline Malha (Tyler) & Abertura (mm) & Retida Simples & Retida Acumulada & Passante Acumulada \\
\hline 3 & 6,730 & $1,24 \%$ & $1,24 \%$ & $98,76 \%$ \\
\hline 4 & 4,760 & $1,88 \%$ & $3,13 \%$ & $96,87 \%$ \\
\hline 6 & 3,360 & $3,97 \%$ & $7,09 \%$ & $92,91 \%$ \\
\hline 8 & 2,380 & $8,42 \%$ & $15,51 \%$ & $84,49 \%$ \\
\hline 10 & 1,680 & $15,72 \%$ & $31,23 \%$ & $68,77 \%$ \\
\hline 14 & 1,190 & $13,55 \%$ & $44,78 \%$ & $55,22 \%$ \\
\hline 20 & 0,841 & $24,20 \%$ & $68,98 \%$ & $31,02 \%$ \\
\hline 24 & 0,707 & $9,44 \%$ & $78,42 \%$ & $21,58 \%$ \\
\hline 28 & 0,595 & $8,09 \%$ & $86,51 \%$ & $13,49 \%$ \\
\hline 35 & 0,420 & $7,80 \%$ & $94,30 \%$ & $5,70 \%$ \\
\hline 48 & 0,297 & $2,43 \%$ & $96,74 \%$ & $3,26 \%$ \\
\hline 65 & 0,210 & $1,62 \%$ & $98,36 \%$ & $1,64 \%$ \\
\hline \multirow[t]{2}{*}{ finos } & - & $1,64 \%$ & $100,00 \%$ & $0,00 \%$ \\
\hline & TOTAL & $100,00 \%$ & & \\
\hline
\end{tabular}




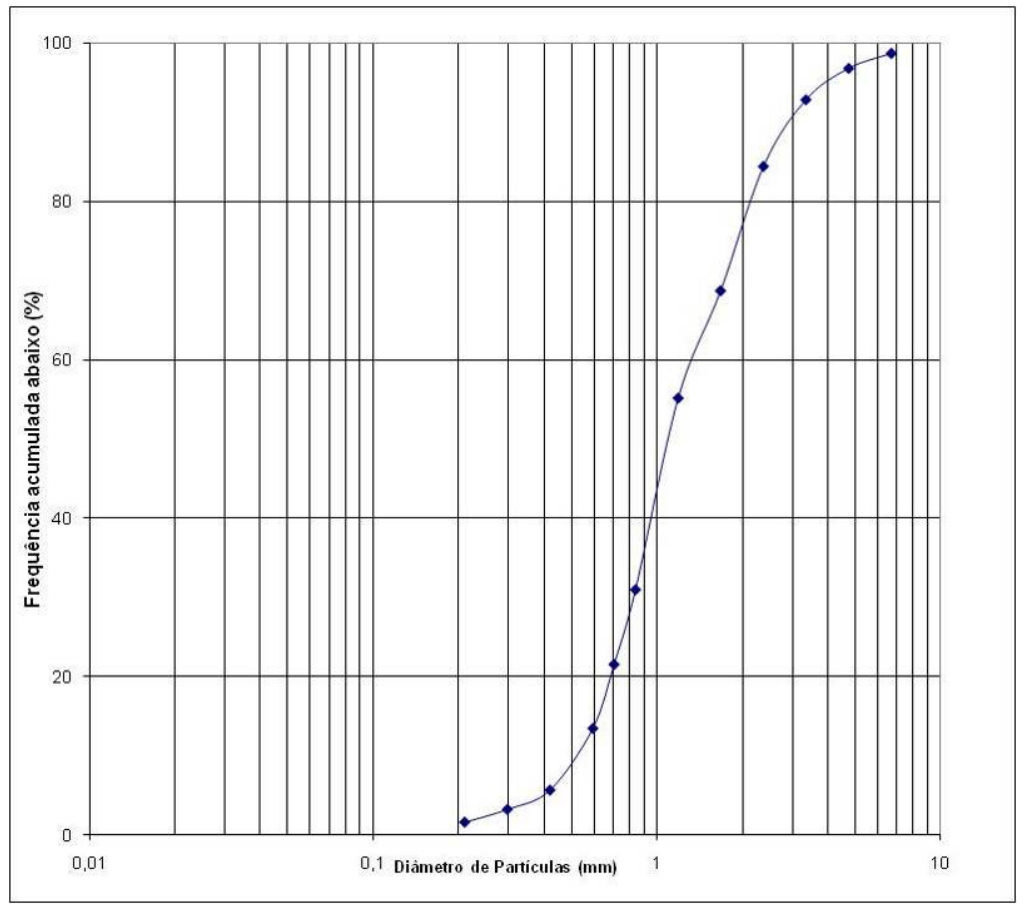

Figura 5.3 - Distribuição granulométrica da amostra granulada tal qual.

Tabela 5.2 - Distribuição granulométrica da amostra resfriada tal qual.

\begin{tabular}{|c|c|c|c|c|}
\hline Malha (Tyler) & Abertura (mm) & Retida Simples & Retida Acumulada & Passante Acumulada \\
\hline & 101,6 & $0,00 \%$ & $0,00 \%$ & $100,00 \%$ \\
\hline & 76,2 & $12,75 \%$ & $12,75 \%$ & $87,25 \%$ \\
\hline & 50,8 & $33,11 \%$ & $45,86 \%$ & $54,14 \%$ \\
\hline & 25,4 & $41,32 \%$ & $87,18 \%$ & $12,82 \%$ \\
\hline & 12,7 & $7,82 \%$ & $95,00 \%$ & $5,00 \%$ \\
\hline 3 & 6,730 & $1,76 \%$ & $96,76 \%$ & $3,24 \%$ \\
\hline 4 & 4,760 & $0,73 \%$ & $97,50 \%$ & $2,50 \%$ \\
\hline 8 & 3,360 & $0,55 \%$ & $98,04 \%$ & $1,96 \%$ \\
\hline 10 & 2,380 & $0,46 \%$ & $98,50 \%$ & $1,50 \%$ \\
\hline 48 & 1,680 & $0,40 \%$ & $98,90 \%$ & $1,10 \%$ \\
\hline 65 & 0,297 & $0,95 \%$ & $99,85 \%$ & $0,15 \%$ \\
\hline finos & 0,210 & $0,07 \%$ & $99,92 \%$ & $0,08 \%$ \\
\hline & - & $0,08 \%$ & $100,00 \%$ & $0,00 \%$ \\
\hline
\end{tabular}




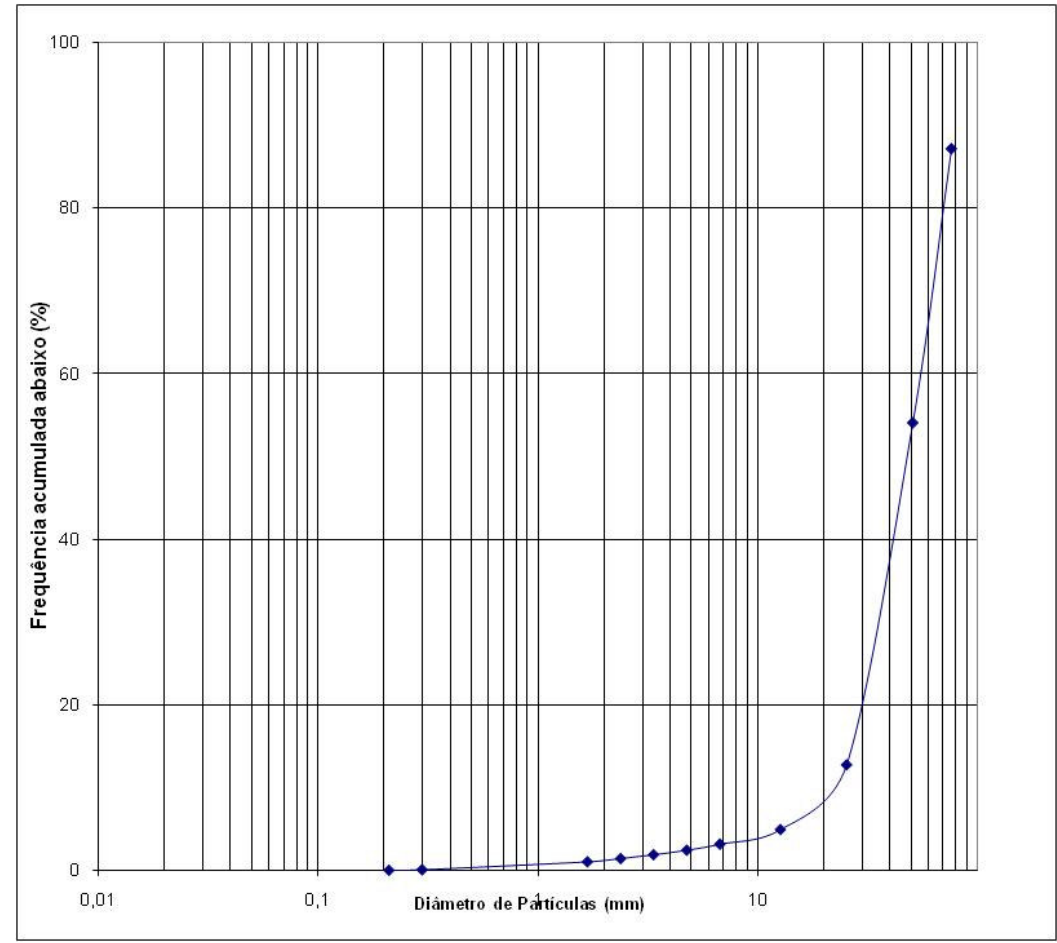

Figura 5.4 - Distribuição granulométrica da amostra resfriada tal qual.

O material foi então arquivado. De acordo com a distribuição obtida, observou-se a necessidade de britagem da amostra resfriada antes da moagem em moinho de barras. Já a escória granulada demonstrou a não necessidade desta etapa. Escolheu-se então realizar ensaios de concentração com a escória granulada apenas.

Outra alíquota de escória granulada foi então tomada, o material foi quarteado e duas alíquotas distintas foram obtidas. Estas duas subamostras foram então preparadas para ensaios de concentração, uma para ensaios de líquido denso e outra para ensaio com mesa Mozley. O material foi quarteado em alíquotas de 2 $\mathrm{kg}$ e moído no moinho de barras da figura 5.5. Encerrada a moagem, quando a diferença entre as massas retidas em ensaios consecutivos era inferior a $30 \%$, o material foi pesado e totalmente quarteado, peneirado e foram obtidas as frações granulométricas para os ensaios de meio denso e mesa Mozley. 


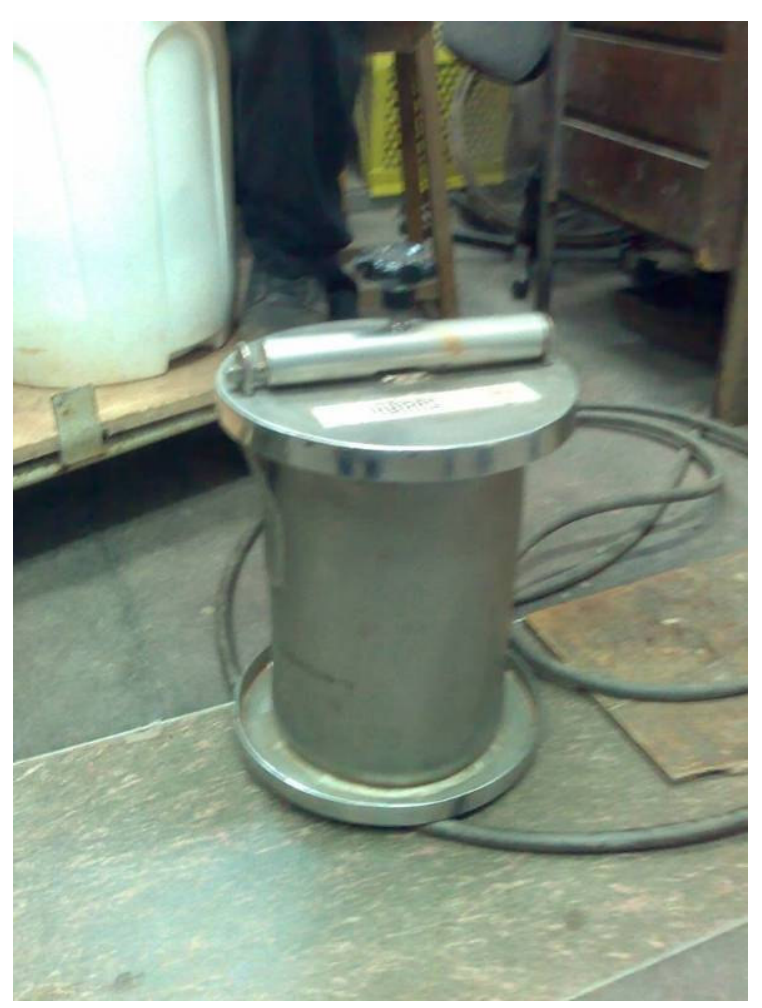

Figura 5.5 - Moinho de barras utilizado na preparação de amostras.

A amostra final foi então peneirada. O resultado obtido encontra-se descrito na tabela 5.3 e na figura 5.6.

Tabela 5.3 - Resultado do peneiramento da escória granulada moída.

\begin{tabular}{|c|c|c|c|c|}
\hline Malha (Tyler) & Abertura (mm) & Retida Simples & Retida Acumulada & Passante Acumulada \\
\hline 20 & 0,841 & $43,91 \%$ & $43,91 \%$ & $56,09 \%$ \\
\hline 35 & 0,420 & $30,36 \%$ & $74,26 \%$ & $25,74 \%$ \\
\hline 65 & 0,210 & $5,68 \%$ & $79,94 \%$ & $20,06 \%$ \\
\hline 100 & 0,149 & $5,31 \%$ & $85,26 \%$ & $14,74 \%$ \\
\hline 200 & 0,074 & $1,72 \%$ & $86,98 \%$ & $13,02 \%$ \\
\hline finos & - & $13,02 \%$ & $100,00 \%$ & $0,00 \%$ \\
\hline & TOTAL & $\mathbf{1 0 0 , 0 0 \%}$ & & \\
\hline
\end{tabular}




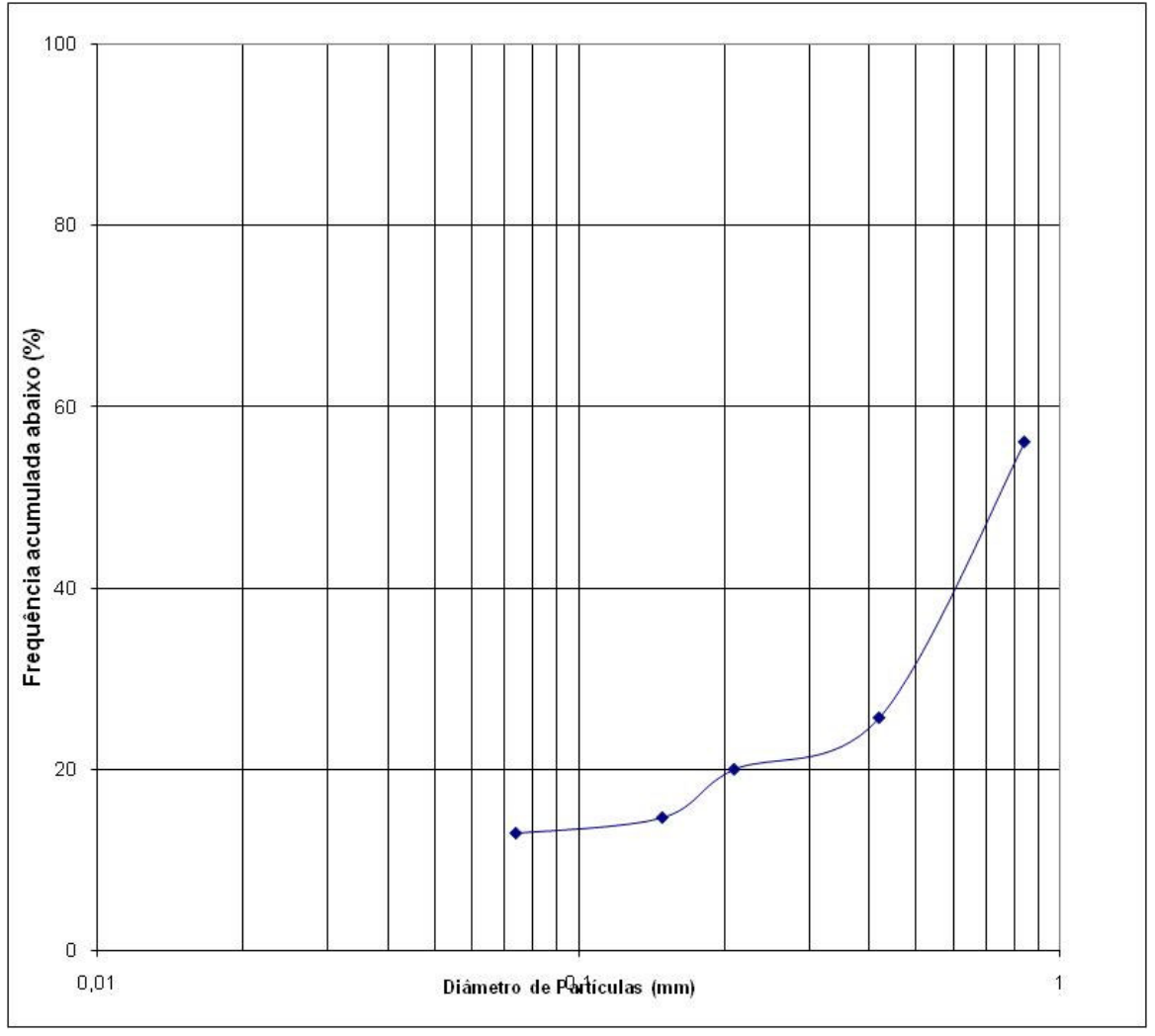

Figura 5.6 - Distribuição granulométrica da amostra granulada moída.

A grande quantidade de massa retida em 20\# possuía fragmentos metálicos em alguma quantidade e de tamanhos diversos, que são praticamente impossíveis de moer e foram retirados para realização do ensaio. Esse material pode ser observado na figura 5.7. 


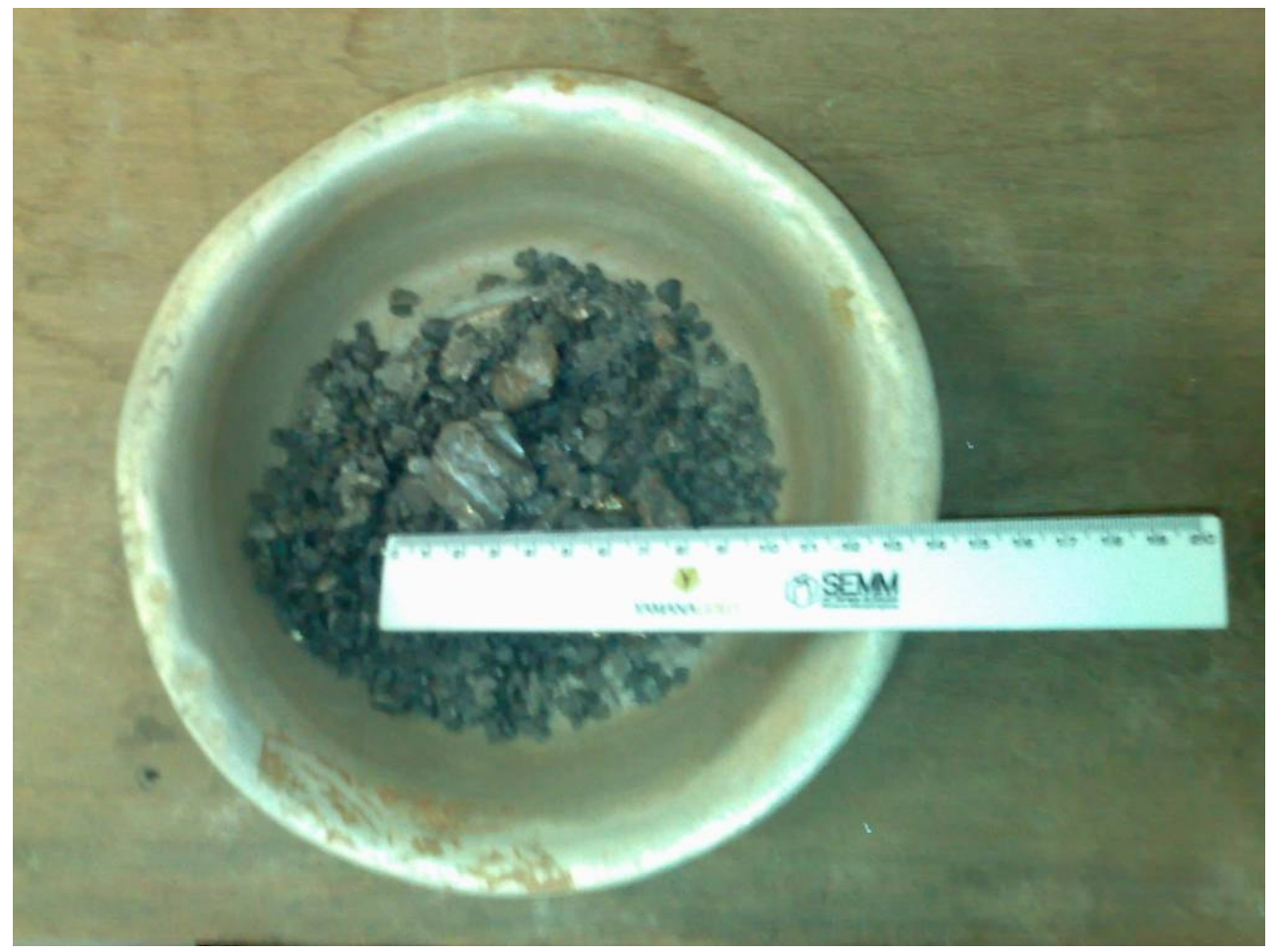

Figura 5.7 - Fragmentos metálicos da amostra granulada moída.

As alíquotas foram novamente quarteadas para produzir três frações distintas: testemunho, líquido denso e mesa.

\subsection{MICROSCOPIA ELETRÔNICA DE VARREDURA}

Foi realizada uma avaliação das amostras por microscopia eletrônica de varredura no LCT (Laboratório de Caracterização Tecnológica) do Departamento de Engenharia de Minas e de Petróleo (PMI) da Escola Politécnica da USP. Foram realizadas análises químicas de cada escória por fluorescência de raios- $X$ $(\mathrm{XRF})$. Os resultados foram lavrados sob o $\mathrm{n}^{0} 335 / 09$, e os resultados são apresentados em base calcinada e normalizados a 100\%, na tabela 5.4 . 
Tabela 5.4 - Análises químicas por XRF.

\begin{tabular}{|c|c|c|}
\hline $\mathbf{N}$ 우 & $\mathbf{2 7 8 7 / 0 9}$ & $\mathbf{2 7 8 8 / 0 9}$ \\
\hline Nome da Amostra & Escória Resfriada & Escória Granulada \\
\hline $\mathrm{MgO}$ & 5,75 & 7,38 \\
\hline $\mathrm{Al}_{2} \mathrm{O}_{3}$ & 0,25 & 0,25 \\
\hline $\mathrm{SiO}_{2}$ & 7,32 & 18,3 \\
\hline $\mathrm{P}_{2} \mathrm{O}_{5}$ & 0,68 & 0,44 \\
\hline $\mathrm{SO}_{3}$ & 0,13 & 0,03 \\
\hline $\mathrm{K}_{2} \mathrm{O}$ & 0,02 & 0,02 \\
\hline $\mathrm{CaO}$ & 21,1 & 22,1 \\
\hline $\mathrm{TiO}_{2}$ & 0,02 & Não Detectado \\
\hline $\mathrm{V}_{2} \mathrm{O}_{5}$ & Não Detectado & 0,05 \\
\hline $\mathrm{Cr}_{2} \mathrm{O}_{3}$ & 1,71 & 2,09 \\
\hline $\mathrm{MnO}_{\mathrm{Fe}} \mathrm{O}_{3}$ & 0,11 & 0,12 \\
\hline $\mathrm{Co}_{3} \mathrm{O}_{4}$ & 62,3 & 48,6 \\
\hline $\mathrm{NiO}$ & 0,03 & 0,02 \\
\hline $\mathrm{SrO}$ & 0,58 & 0,58 \\
\hline $\mathrm{TOTAL}$ & 0,02 & 0,03 \\
\hline & $\mathbf{1 0 0 , 0 0}$ & $\mathbf{1 0 0 , 0 0}$ \\
\hline
\end{tabular}

Como comparação, a tabela 5.5 mostra a análise química da escória granulada realizada por via úmida, no laboratório da Morro Azul

Tabela 5.5 - Análise química da escória granulada por via úmida.

\begin{tabular}{|c|c|c|c|c|c|c|c|c|c|}
\hline Elemento & $\mathbf{N i}^{0}$ & $\mathrm{NiO}$ & $\mathrm{Fe}^{0}$ & $\mathbf{F e O}$ & $\mathrm{SiO}_{2}$ & $\mathrm{MgO}+\mathrm{CaO}$ & $\mathbf{C}$ & $\mathbf{S}$ & $\mathbf{P}$ \\
\hline Valor & 0,60 & - & 35,6 & - & 15,0 & 24,1 & 0,894 & 0,071 & 0,25 \\
\hline
\end{tabular}

\subsubsection{ESCÓRIA RESFRIADA}

A figura 5.8 mostra um aspecto geral da população observada. Comparativamente à amostra da escória granulada, as partículas são maiores, melhor cristalizadas porquanto resfriadas lentamente, as fases aparecem melhor definidas e existem rechupes. A MEV permite apontar pontos ou regiões de interesse e obter uma análise elementar. Isto foi feito para auxiliar a identificação das fases. É importante ressaltar também que as fotomicrografias não representam cores, mas brilhos. Os tons variam do negro ao branco, em função 
do número atômico dos elementos presentes em cada fase. Isto é, as fases ricas em ferro são as mais brilhantes e os silicatos, os mais escuros.

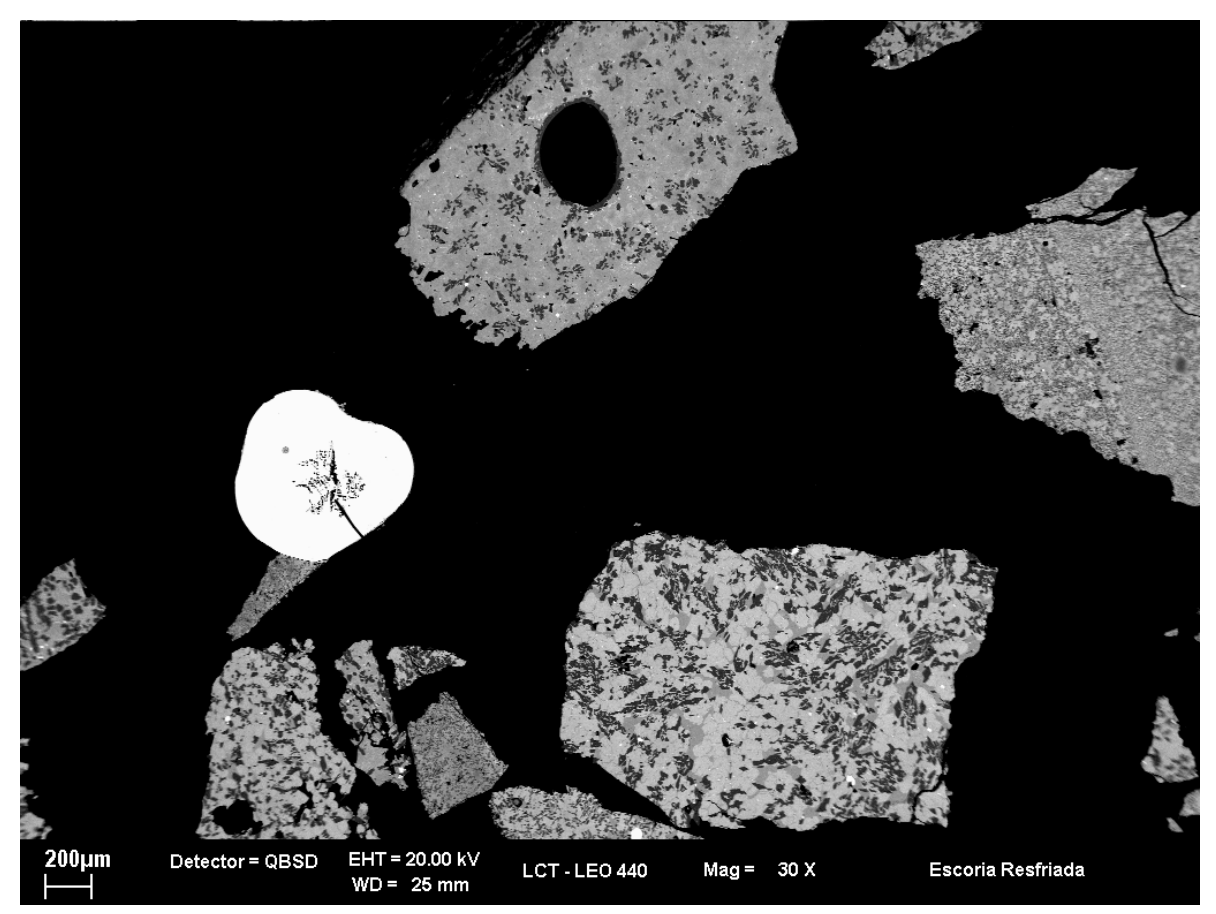

Figura 5.8 - Amostra resfriada, aparência geral.

$\mathrm{Na}$ figura 5.8, nota-se uma partícula esferoidal e brilhante de ferroníquel bem cristalizada. Foi feita a análise de um ponto desta partícula, mostrada na figura 5.9, espectro denominado P1, uma partícula com um rechupe (centro e acima) e diferentes texturas.

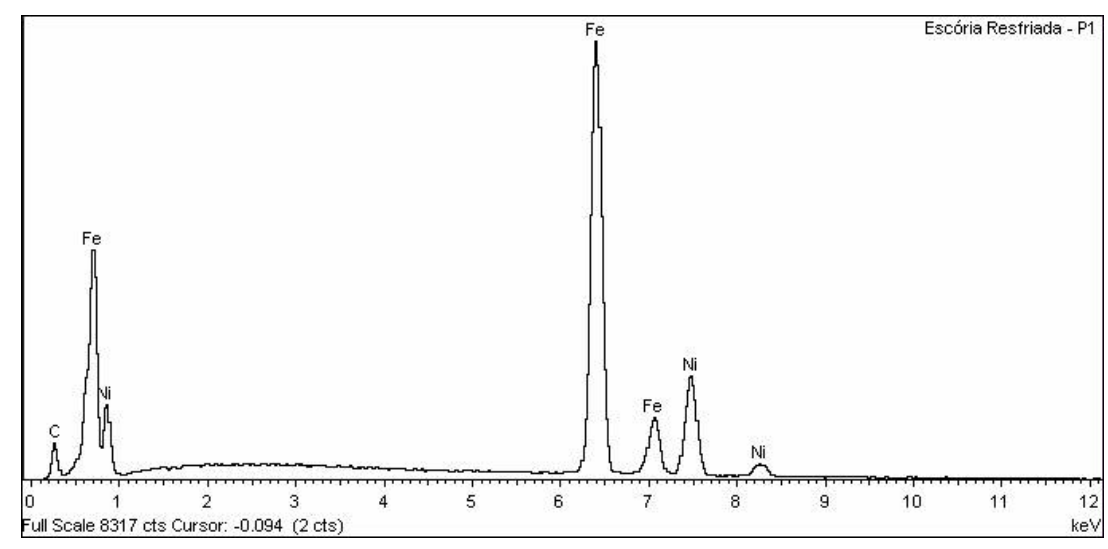

Figura 5.9 - Espectro do ponto P1. 
A figura 5.10 é um detalhe do grão claro abaixo do centro da figura 5.8. O ponto P4 é uma fase de silicato de cálcio. Os pontos P2 e P3 são fases contendo cálcio e ferro, certamente da escória, pois seu brilho é menor do que o das fases P1 e P5, que são de ferro e níquel.

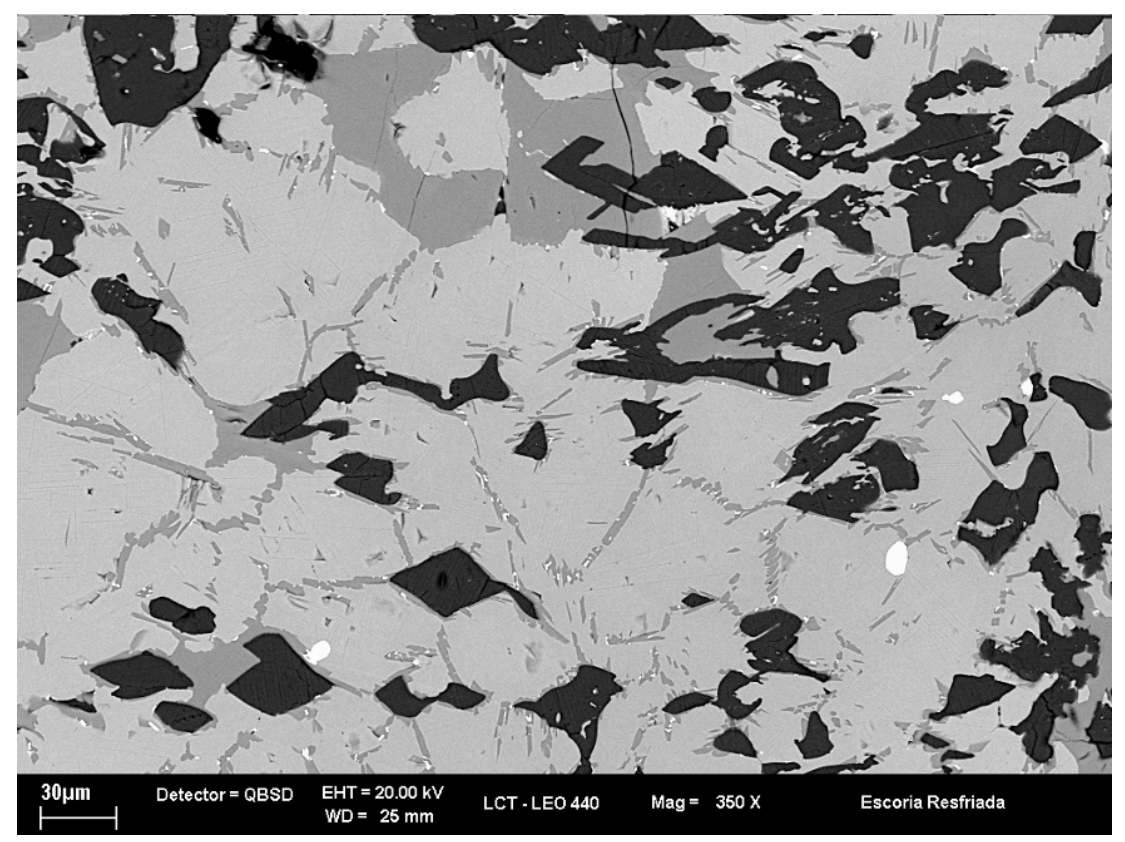

Figura 5.10 - Amostra resfriada (detalhe).

As figuras 5.11 e 5.12 são detalhes da partícula mais escura da figura 5.9. Notase um rechupe na parte central e superior. O ponto P5 é uma inclusão metálica menor que $5 \mu \mathrm{m}$. 


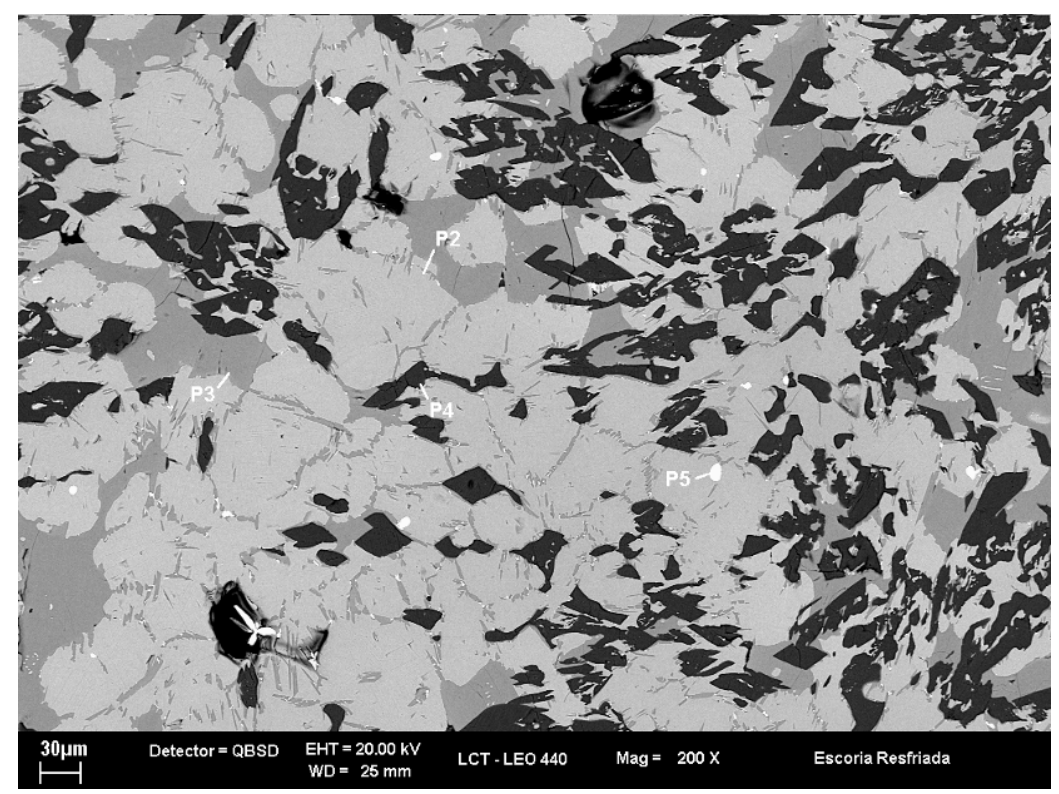

Figura 5.11 - Amostra resfriada (detalhe).

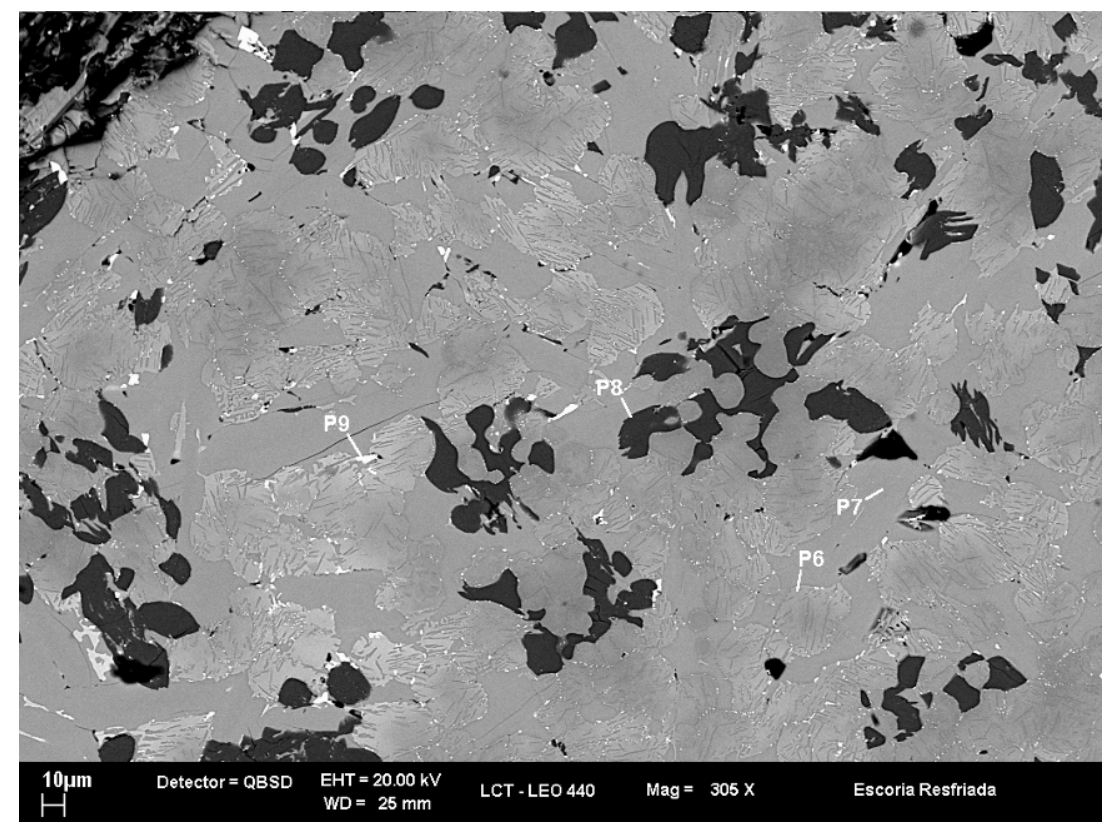

Figura 5.12 - Amostra resfriada (detalhe).

Notam-se rechupes e fases intercrescidas, porém segregadas. A figura 5.13 é um detalhe da região próxima ao rechupe na figura 5.9 (partícula mais escura com rechupe). Nota-se a fase segregada no contorno do rechupe (P10), rica em Ca e Si. O espectro de P10 é mostrado na figura 5.14. 


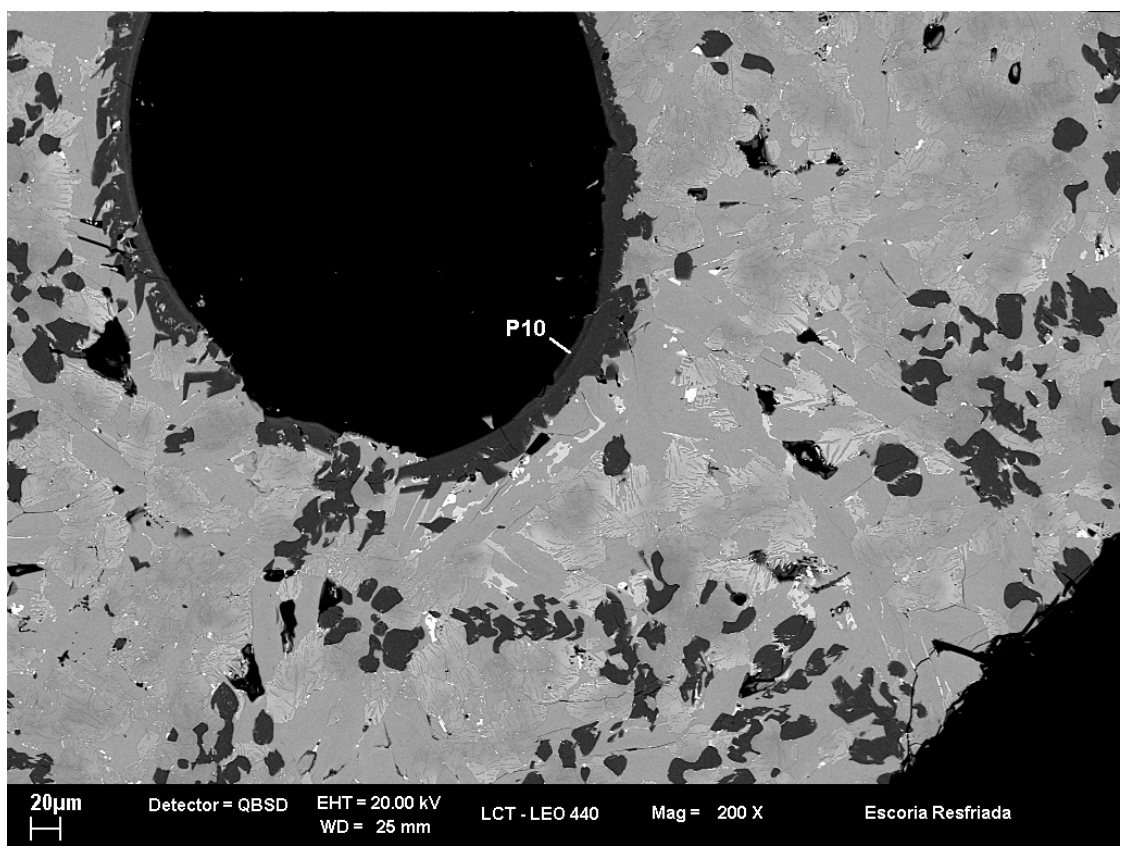

Figura 5.13 - Amostra resfriada (detalhe).

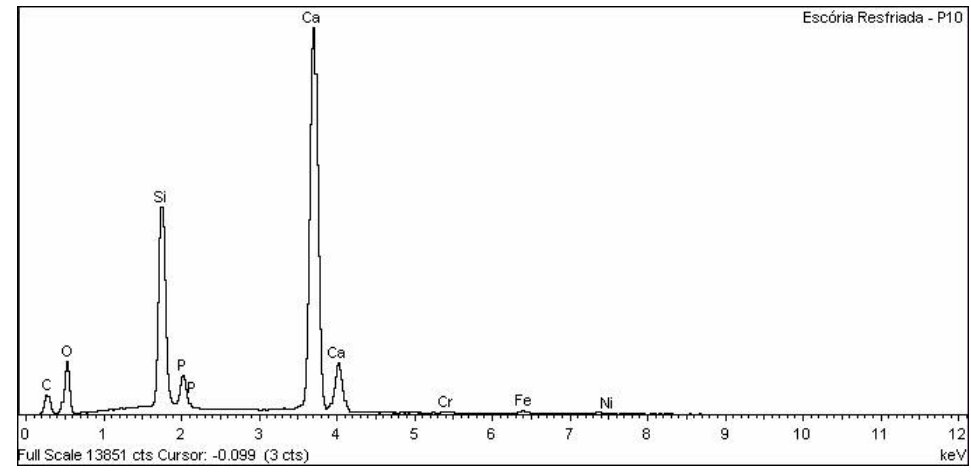

Figura 5.14 - Espectro do ponto P10.

A figura 5.15, finalmente, mostra partículas com rechupes em diferentes fases. As fases analisadas na partícula metálica são fases Fe-Cr-Ni e Fe-Ni segregadas. A figura 5.16 mostra outros detalhes da mesma escória. 


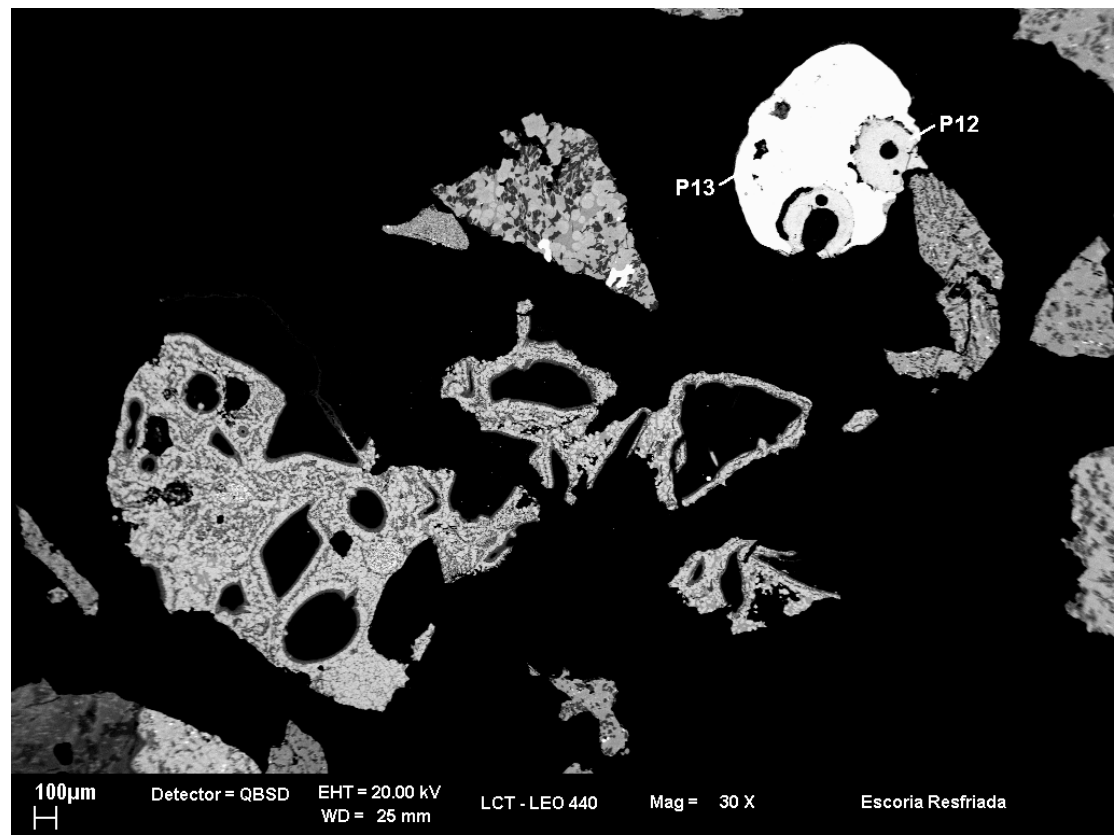

Figura 5.15 - Amostra resfriada (detalhe).

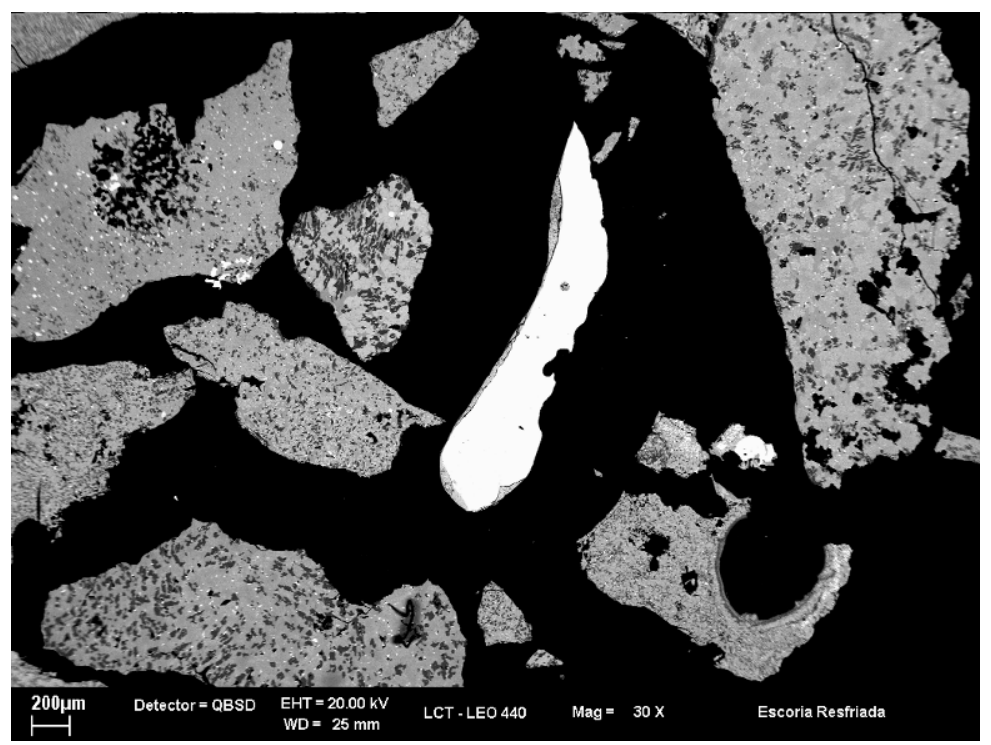

Figura 5.16 - Amostra resfriada (detalhe).

\subsubsection{ESCÓRIA GRANULADA}

Com esta escória, o aspecto é completamente diferente: as partículas têm formato esférico devido ao resfriamento súbito a partir do estado de fusão (líquido). Os rechupes são mais freqüentes e menores, o que se justifica pela velocidade de resfriamento. As texturas são mais homogêneas dentro de cada 
partícula do que na escória resfriada, onde as diferentes fases tiveram tempo de segregar durante o resfriamento. A figura 5.17 mostra um aspecto bastante típico.

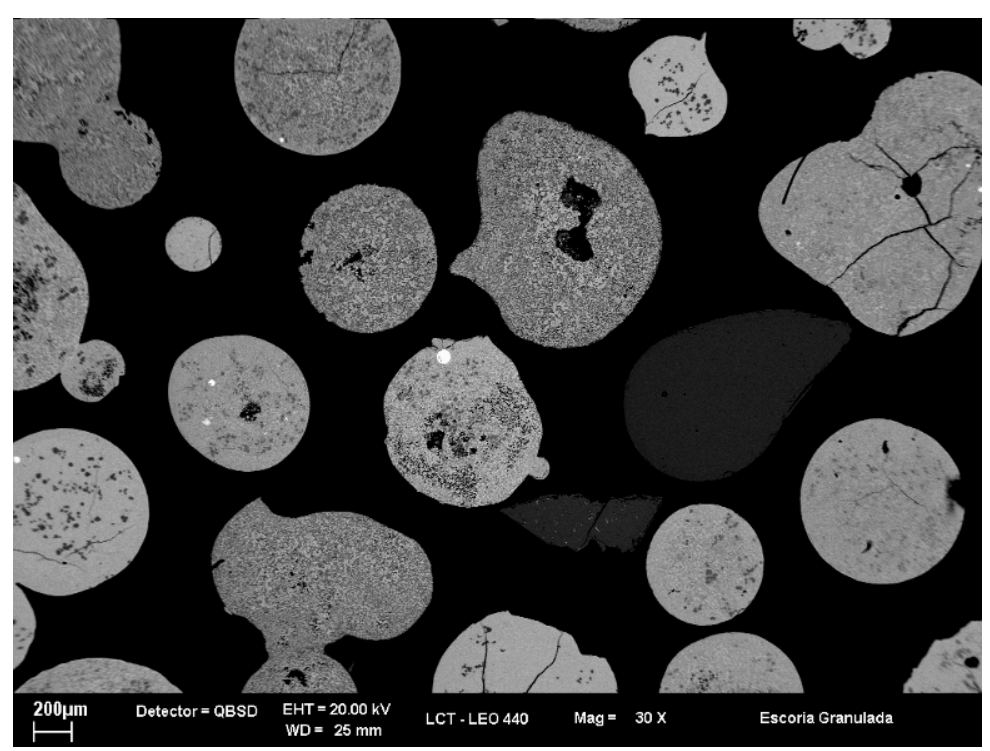

Figura 5.17 - Amostra granulada, aspecto geral.

A figura 5.18 apresenta um detalhe de uma das partículas. Notam-se as estruturas "estelares", formadas a partir de um núcleo que cresce radialmente e forma ramos (dendritas). A área zebrada (P3) é um silicato de cálcio que contém pouco $\mathrm{Cr}$ e $\mathrm{Fe}$, cujo espectro é mostrado na figura 5.19.

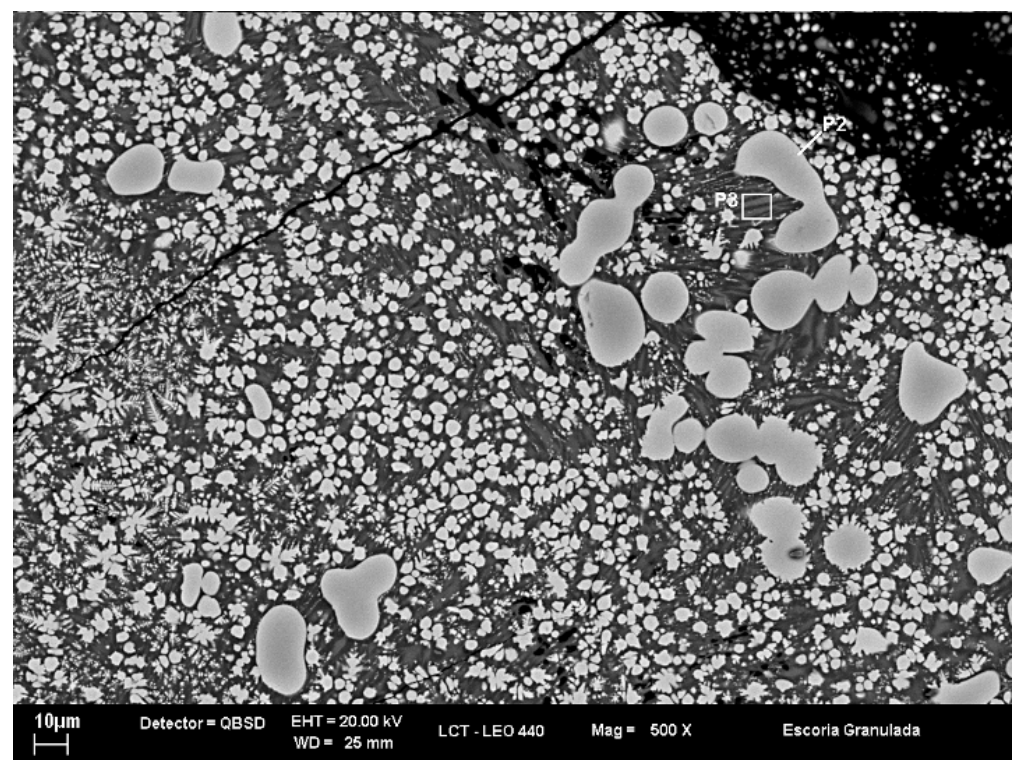

Figura 5.18 - Amostra granulada (detalhe). 


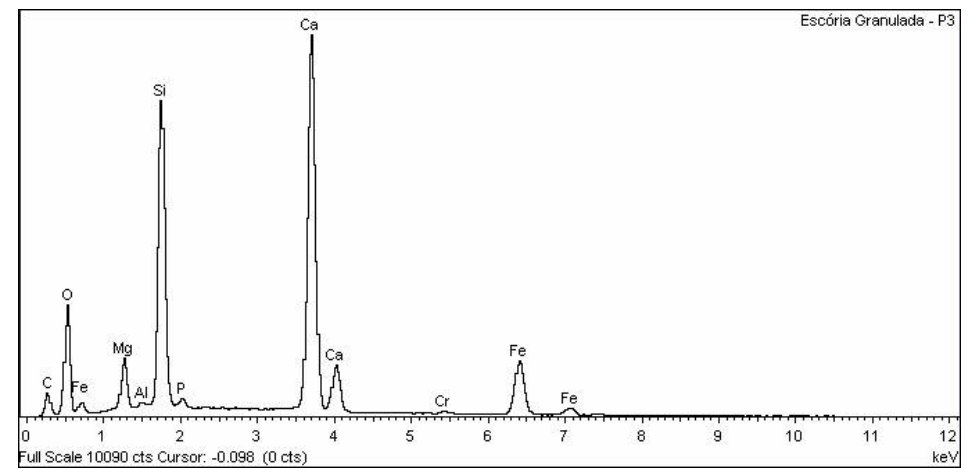

Figura 5.19 - Espectro do ponto P3.

A figura 5.20 mostra outro detalhe de outra partícula. As gotas que se vêem são realmente gotas de escória (espectro P5, figura 5.21) presas na textura (muito fina). A esfera brilhante é de Ni, com pouco Fe (espectro P6, figura 5.22).
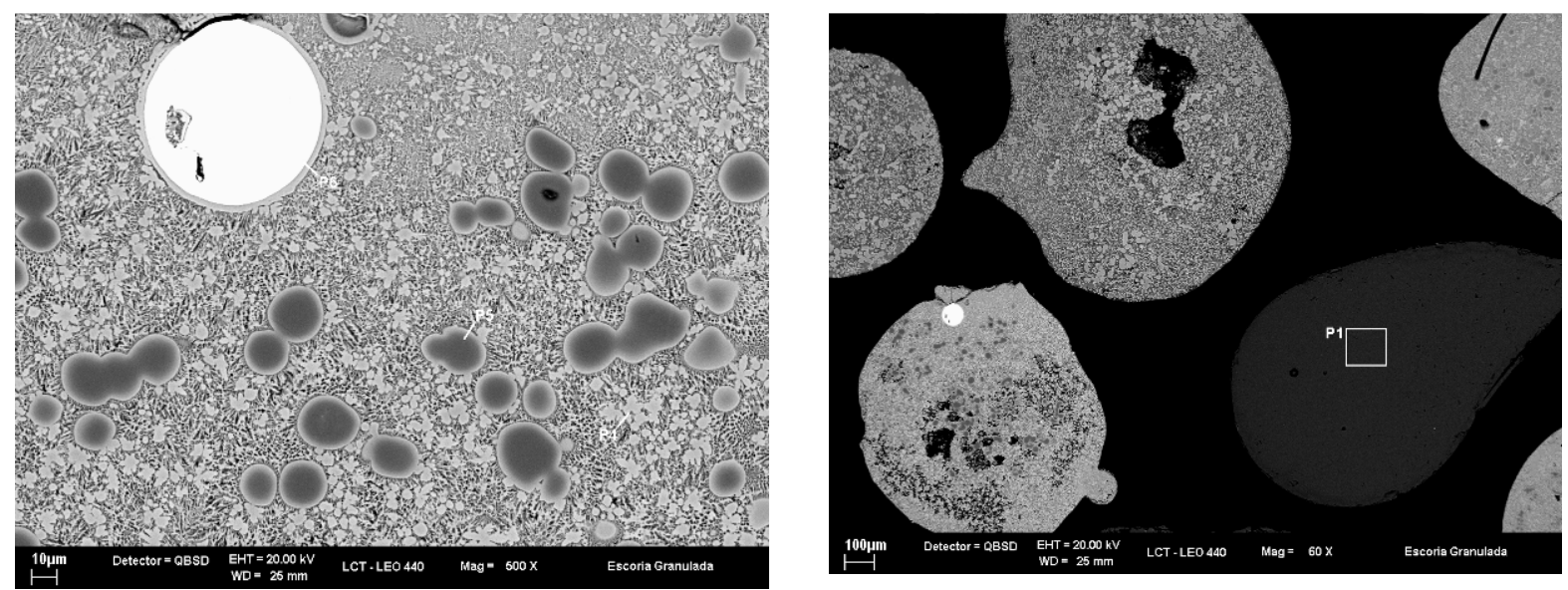

Figura 5.20 - Amostra granulada (detalhes).

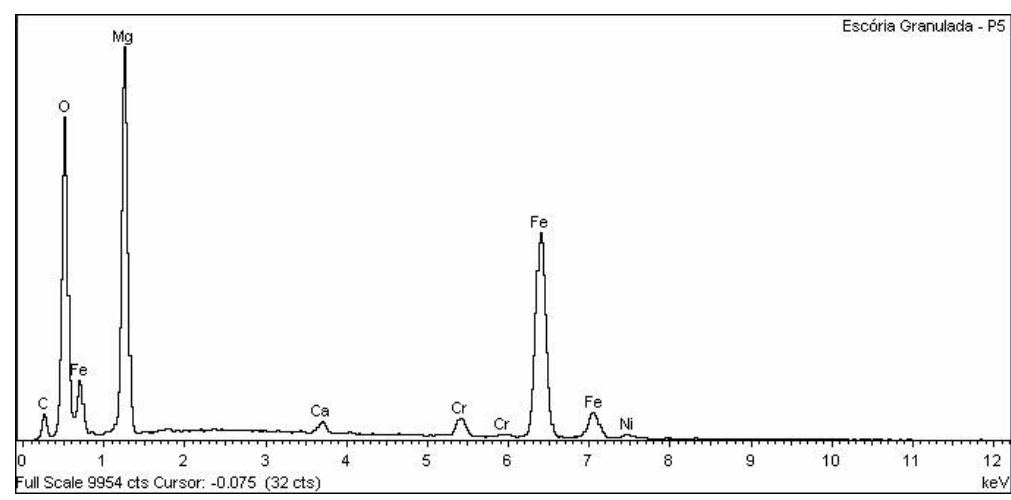

Figura 5.21 - Espectro do ponto P5. 


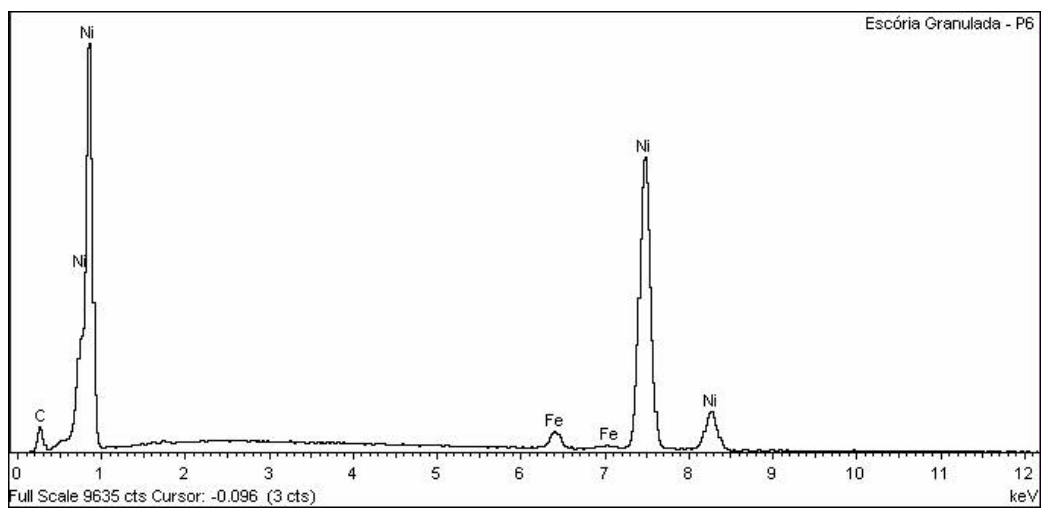

Figura 5.22 - Espectro do ponto P6.

Outro detalhe pode ser observado na figura 5.23.

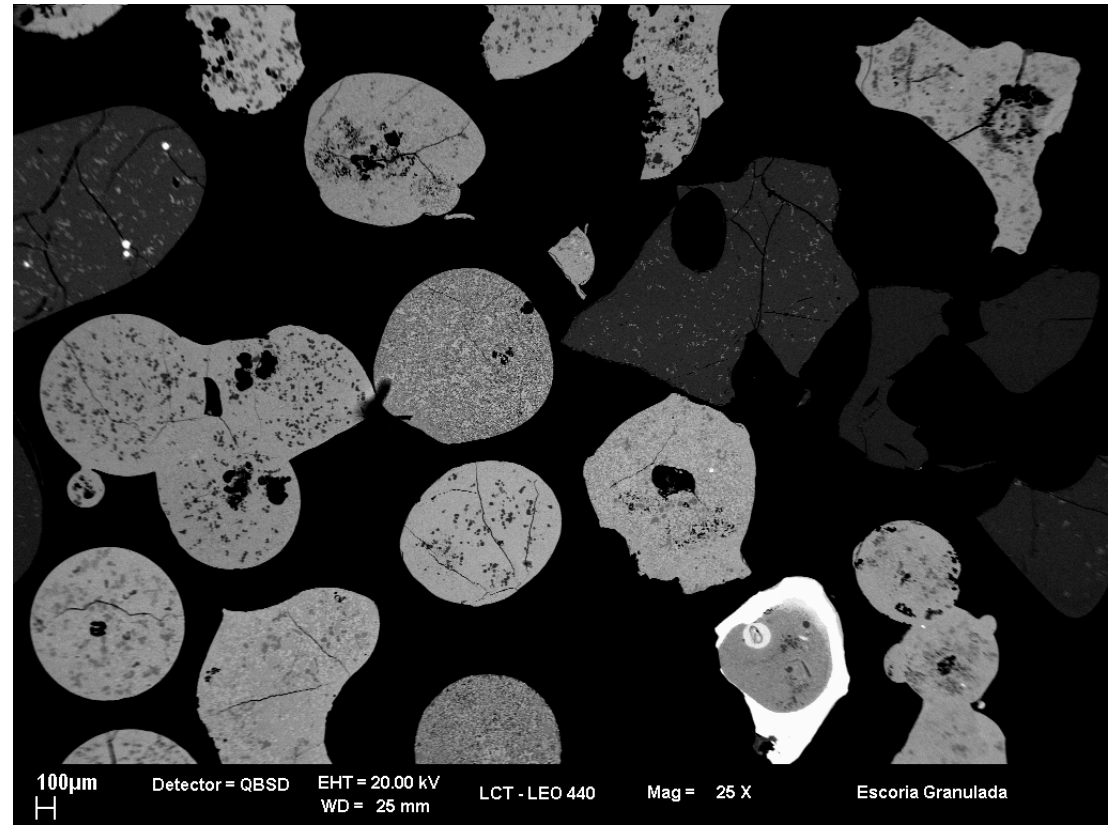

Figura 5.23 - Amostra granulada (detalhe).

\subsubsection{CONCLUSÃO}

As duas amostras apresentam diferenças texturais notáveis, devido ao processo de resfriamento diferenciado que receberam: a amostra resfriada solidificou-se e esfriou lentamente; já a amostra granulada foi lançada em água e resfriada e 
solidificada rapidamente, o que acarreta a sua forma de gotas. Dois processos independentes ocorrem durante a solidificação de uma fase líquida:

- a nucleação, que é o aparecimento de cristais microscópicos individuais no seio da massa fundida. Nucleiam-se inicialmente as espécies de ponto de fusão mais elevado; e

- o crescimento dos núcleos, causado pela precipitação de novos cristais sobre os núcleos. Inicialmente, o crescimento é devido à precipitação de cristais da mesma fase.

Conforme o material resfria, novas espécies começam a nuclear e a crescer, até atingir a sua textura final. Via de regra, a solidificação ocorre de fora para dentro, o núcleo sendo a última região a solidificar-se - contendo, então, as espécies de ponto de fusão mais baixo. Como o volume sólido é maior que o volume líquido, sobram espaços vazios, que são os rechupes.

O resfriamento lento da amostra resfriada ocasionou a separação mais nítida das diferentes fases. Já o resfriamento súbito da amostra granulada forçou o intercrescimento das mesmas. A dimensão dos rechupes é totalmente diferente em ambas as fases. Estas diferenças texturais certamente se refletem em comportamentos mecânicos e na cominuição (dureza, tenacidade, plasticidade).

\subsection{DETERMINAÇÃO DOS ÍNDICES DE TRABALHO (WI)}

Para os índices de trabalho, foi escolhida a malha de controle como 0,425 mm, o equivalente à malha o 40 da série ASTM. Foi realizado um teste para cada escória, como é descrito a seguir.

\subsubsection{ESCÓRIA RESFRIADA}

A escória resfriada preparada para o teste possuía a distribuição granulométrica indicada na tabela 5.6. Demais parâmetros encontram-se indicados na tabela 5.7. 
Tabela 5.6 - Distribuição granulométrica da alimentação, escória resfriada.

\begin{tabular}{|c|c|c|c|}
\hline $\begin{array}{c}\text { Malha } \\
\text { (ASTM) }\end{array}$ & $\begin{array}{c}\text { Peso Retido } \\
\text { Acumulado }\end{array}$ & $\begin{array}{c}\text { Fração Retida } \\
\text { Acumulada }\end{array}$ & $\begin{array}{c}\text { Fração Passante } \\
\text { Acumulada }\end{array}$ \\
\hline 8 & 504,5 & 35,52 & 64,48 \\
\hline 12 & 636,3 & 44,79 & 55,21 \\
\hline 16 & 818,1 & 57,59 & 42,41 \\
\hline 20 & 961,0 & 67,65 & 32,35 \\
\hline 30 & 1054,0 & 74,20 & 25,80 \\
\hline 40 & 1151,7 & 81,08 & 18,92 \\
\hline 50 & 1219,1 & 85,82 & 14,18 \\
\hline 70 & 1266,6 & 89,17 & 10,83 \\
\hline 100 & 1297,0 & 91,31 & 8,69 \\
\hline 140 & 1329,2 & 93,57 & 6,43 \\
\hline 200 & 1357,0 & 95,53 & 4,47 \\
\hline 270 & 1374,2 & 96,74 & 3,26 \\
\hline 325 & 1383,2 & 97,37 & 2,63 \\
\hline Fundo & $\mathbf{1 4 2 0 , 5}$ & $\mathbf{1 0 0 , 0 0}$ & $\mathbf{0 , 0 0}$ \\
\hline
\end{tabular}

Tabela 5.7 - Parâmetros de teste, escória resfriada.

\begin{tabular}{|l|c|c|}
\hline \multicolumn{1}{|c|}{ Parâmetro } & Unidade & Valor \\
\hline Massa específica aparente & $\mathrm{lb} / \mathrm{ft}^{3}$ & 176 \\
\hline Carga do moinho & $\mathrm{g}$ & 1974,0 \\
\hline Fração passante na malha do teste & Adimensional & 0,189 \\
\hline IPP & $\mathrm{g}$ & 564,0 \\
\hline
\end{tabular}

Foram então realizadas nove iterações até que a estabilização fosse atingida, conforme a tabela 5.8. Ao final, foi realizado o peneiramento da carga circulante e do produto final, conforme tabelas 5.9 e 5.10 , respectivamente. A tabela 5.11 mostra os demais resultados, assim como o WI calculado. 
Tabela 5.8 - Planilha do teste de WI, escória resfriada.

\begin{tabular}{|c|c|c|c|c|c|c|c|}
\hline Período & $\mathbf{Q}(\mathbf{r p m})$ & $\mathbf{R}(\mathbf{g})$ & $\mathbf{S}(\mathbf{g})$ & $\mathbf{+} \mathbf{M}(\mathbf{g})$ & $\mathbf{T}(\mathbf{g})$ & $\mathbf{U}$ (g) & $\mathbf{V}$ (g/rpm) \\
\hline 1 & 100 & 1974,0 & 373,1 & 1435,6 & 538,4 & 165,3 & 1,653 \\
\hline 2 & 280 & 538,4 & 101,8 & 1474,6 & 499,4 & 397,6 & 1,420 \\
\hline 3 & 331 & 499,4 & 94,4 & 1362,2 & 611,8 & 517,4 & 1,563 \\
\hline 4 & 287 & 611,8 & 115,6 & 1465,0 & 509,0 & 393,4 & 1,371 \\
\hline 5 & 341 & 509,0 & 96,2 & 1474,2 & 496,8 & 400,6 & 1,175 \\
\hline 6 & 400 & 496,8 & 93,9 & 1410,0 & 564,0 & 470,1 & 1,175 \\
\hline 7 & 389 & 564,0 & 106,6 & 1410,0 & 564,0 & 457,4 & 1,176 \\
\hline 8 & 389 & 564,0 & 106,6 & 1410,0 & 564,0 & 457,4 & 1,176 \\
\hline $\mathbf{9}$ & $\mathbf{3 8 9}$ & $\mathbf{5 6 4 , 0}$ & $\mathbf{1 0 6 , 6}$ & $\mathbf{1 4 1 0 , 0}$ & $\mathbf{5 6 4 , 0}$ & $\mathbf{4 5 7 , 4}$ & $\mathbf{1 , 1 7 6}$ \\
\hline
\end{tabular}

Tabela 5.9 - Distribuição granulométrica da carga circulante, escória resfriada.

\begin{tabular}{|c|c|c|c|}
\hline Malha (ASTM) & $\begin{array}{c}\text { Peso Retido } \\
\text { Acumulado }\end{array}$ & $\begin{array}{c}\text { Fração Retida } \\
\text { Acumulada }\end{array}$ & $\begin{array}{c}\text { Fração Passante } \\
\text { Acumulada }\end{array}$ \\
\hline 8 & 490,6 & 34,88 & 65,12 \\
\hline 12 & 671,4 & 47,74 & 52,26 \\
\hline 16 & 949,5 & 67,51 & 32,49 \\
\hline 20 & 1129,9 & 80,33 & 19,67 \\
\hline 30 & 1246,5 & 88,62 & 11,38 \\
\hline $\mathbf{4 0}$ & $\mathbf{1 4 0 6 , 5}$ & $\mathbf{1 0 0 , 0 0}$ & $\mathbf{0 , 0 0}$ \\
\hline
\end{tabular}

Tabela 5.10 - Distribuição granulométrica do produto final, escória resfriada.

\begin{tabular}{|c|c|c|c|}
\hline $\begin{array}{c}\text { Malha } \\
\text { (ASTM) }\end{array}$ & $\begin{array}{c}\text { Peso Retido } \\
\text { Acumulado }\end{array}$ & $\begin{array}{c}\text { Fração Retida } \\
\text { Acumulada }\end{array}$ & $\begin{array}{c}\text { Fração Passante } \\
\text { Acumulada }\end{array}$ \\
\hline 50 & 108,6 & 19,27 & 80,73 \\
\hline 70 & 194,5 & 34,50 & 65,50 \\
\hline 100 & 249,9 & 44,33 & 55,67 \\
\hline 140 & 315,0 & 55,88 & 44,12 \\
\hline 200 & 370,1 & 65,66 & 34,34 \\
\hline 270 & 407,6 & 72,31 & 27,69 \\
\hline 325 & 428,4 & 76,00 & 24,00 \\
\hline Fundo & $\mathbf{5 6 3 , 7}$ & $\mathbf{1 0 0 , 0 0}$ & $\mathbf{0 , 0 0}$ \\
\hline
\end{tabular}


Tabela 5.11 - Resultados do teste, escória resfriada.

\begin{tabular}{|l|c|c|}
\hline \multicolumn{1}{|c|}{ Parâmetro } & Unidade & Valor \\
\hline Produto por rotação $(\mathrm{Y})$ & $\mathrm{g}$ & 1,176 \\
\hline $\mathrm{F}_{80}$ do teste & $\mu \mathrm{m}$ & 2870 \\
\hline $\mathrm{P}_{80}$ do teste & $\mu \mathrm{m}$ & 297 \\
\hline Massa retida na malha do teste $(\mathrm{M})$ & $\mathrm{g}$ & 1410,0 \\
\hline Índice de trabalho $(\mathbf{W I})$ & $\mathbf{k W h} / \mathbf{s t}$ & $\mathbf{2 4 , 6 1}$ \\
\hline
\end{tabular}

Estes resultados serão discutidos mais adiante.

\subsubsection{ESCÓRIA GRANULADA}

A escória granulada preparada para o teste possuía a distribuição granulométrica indicada na tabela 5.12. Os demais parâmetros encontram-se indicados na tabela 5.13.

Tabela 5.12 - Distribuição granulométrica da alimentação, escória granulada.

\begin{tabular}{|c|c|c|c|}
\hline $\begin{array}{c}\text { Malha } \\
\text { (ASTM) }\end{array}$ & $\begin{array}{c}\text { Peso Retido } \\
\text { Acumulado }\end{array}$ & $\begin{array}{c}\text { Fração Retida } \\
\text { Acumulada }\end{array}$ & $\begin{array}{c}\text { Fração Passante } \\
\text { Acumulada }\end{array}$ \\
\hline 8 & 234,6 & 18,14 & 81,86 \\
\hline 12 & 309,9 & 23,96 & 76,04 \\
\hline 16 & 592,5 & 45,80 & 54,20 \\
\hline 20 & 840,0 & 64,94 & 35,06 \\
\hline 30 & 997,8 & 77,13 & 22,87 \\
\hline 40 & 1139,0 & 88,05 & 11,95 \\
\hline 50 & 1208,3 & 93,41 & 6,59 \\
\hline 70 & 1239,5 & 95,82 & 4,18 \\
\hline 100 & 1255,3 & 97,04 & 2,96 \\
\hline 140 & 1269,1 & 98,11 & 1,89 \\
\hline 200 & 1278,1 & 98,80 & 1,20 \\
\hline 270 & 1282,7 & 99,16 & 0,84 \\
\hline 325 & 1285,4 & 99,37 & 0,63 \\
\hline Fundo & $\mathbf{1 2 9 3 , 6}$ & $\mathbf{1 0 0 , 0 0}$ & $\mathbf{0 , 0 0}$ \\
\hline
\end{tabular}


Tabela 5.13 - Parâmetros de teste, escória granulada.

\begin{tabular}{|l|c|c|}
\hline \multicolumn{1}{|c|}{ Parâmetro } & Unidade & Valor \\
\hline Massa específica aparente & $\mathrm{lb} / \mathrm{ft}^{3}$ & 129 \\
\hline Carga do moinho & $\mathrm{g}$ & 1447,0 \\
\hline Fração passante na malha do teste & Adimensional & 0,120 \\
\hline IPP & $\mathrm{g}$ & 413,0 \\
\hline
\end{tabular}

Foram então realizadas cinco iterações até que a estabilização fosse atingida, conforme a tabela 5.14. Ao final, foi realizado o peneiramento da carga circulante e do produto final, conforme tabelas 5.15 e 5.16 , respectivamente. A tabela 5.17 mostra os demais resultados, assim como o WI calculado.

Tabela 5.14 - Planilha do teste de WI, escória granulada.

\begin{tabular}{|c|c|c|c|c|c|c|c|}
\hline Período & $\mathbf{Q}(\mathbf{r p m})$ & $\mathbf{R}(\mathbf{g})$ & $\mathbf{S}(\mathbf{g})$ & $\mathbf{+} \mathbf{M}(\mathbf{g})$ & $\mathbf{T}(\mathbf{g})$ & $\mathbf{U}(\mathbf{g})$ & $\mathbf{V}(\mathbf{g} / \mathbf{r p m})$ \\
\hline 1 & 100 & 1447,0 & 173,6 & 999,3 & 447,7 & 274,1 & 2,741 \\
\hline 2 & 131 & 447,7 & 53,7 & 1034,0 & 413,0 & 359,3 & 2,743 \\
\hline 3 & 132 & 413,0 & 49,6 & 1034,0 & 413,0 & 363,4 & 2,753 \\
\hline 4 & 132 & 413,0 & 49,6 & 1034,0 & 413,0 & 363,4 & 2,753 \\
\hline $\mathbf{5}$ & $\mathbf{1 3 2}$ & $\mathbf{4 1 3 , 0}$ & $\mathbf{4 9 , 6}$ & $\mathbf{1 0 3 4 , 0}$ & $\mathbf{4 1 3 , 0}$ & $\mathbf{3 6 3 , 4}$ & $\mathbf{2 , 7 5 3}$ \\
\hline
\end{tabular}

Tabela 5.15 - Distribuição granulométrica da carga circulante, escória granulada.

\begin{tabular}{|c|c|c|c|}
\hline $\begin{array}{c}\text { Malha } \\
\text { (ASTM) }\end{array}$ & $\begin{array}{c}\text { Peso Retido } \\
\text { Acumulado }\end{array}$ & $\begin{array}{c}\text { Fração Retida } \\
\text { Acumulada }\end{array}$ & $\begin{array}{c}\text { Fração Passante } \\
\text { Acumulada }\end{array}$ \\
\hline 8 & 2,7 & 0,26 & 99,74 \\
\hline 12 & 5,2 & 0,50 & 99,50 \\
\hline 16 & 21,5 & 2,08 & 97,92 \\
\hline 20 & 110,6 & 10,7 & 89,30 \\
\hline 30 & 360,3 & 34,85 & 65,15 \\
\hline $\mathbf{4 0}$ & $\mathbf{1 0 3 4 , 0}$ & $\mathbf{1 0 0 , 0 0}$ & $\mathbf{0 , 0 0}$ \\
\hline
\end{tabular}


Tabela 5.16 - Distribuição granulométrica do produto final, escória granulada.

\begin{tabular}{|c|c|c|c|}
\hline $\begin{array}{c}\text { Malha } \\
\text { (ASTM) }\end{array}$ & $\begin{array}{c}\text { Peso Retido } \\
\text { Acumulado }\end{array}$ & $\begin{array}{c}\text { Fração Retida } \\
\text { Acumulada }\end{array}$ & $\begin{array}{c}\text { Fração Passante } \\
\text { Acumulada }\end{array}$ \\
\hline 50 & 184,1 & 44,64 & 55,36 \\
\hline 70 & 267,1 & 64,77 & 35,23 \\
\hline 100 & 306,3 & 74,27 & 25,73 \\
\hline 140 & 341,3 & 82,76 & 17,24 \\
\hline 200 & 364,8 & 88,46 & 11,54 \\
\hline 270 & 375,9 & 91,15 & 8,85 \\
\hline 325 & 382,7 & 92,80 & 7,20 \\
\hline Fundo & $\mathbf{4 1 2 , 4}$ & $\mathbf{1 0 0 , 0 0}$ & $\mathbf{0 , 0 0}$ \\
\hline
\end{tabular}

Tabela 5.17 - Resultados do teste, escória granulada.

\begin{tabular}{|l|c|c|}
\hline \multicolumn{1}{|c|}{ Parâmetro } & Unidade & Valor \\
\hline Produto por rotação $(\mathrm{Y})$ & $\mathrm{g}$ & 2,753 \\
\hline $\mathrm{F}_{80}$ do teste & $\mu \mathrm{m}$ & 2380 \\
\hline $\mathrm{P}_{80}$ do teste & $\mu \mathrm{m}$ & 365 \\
\hline Massa retida na malha do teste $(\mathrm{M})$ & $\mathrm{g}$ & 1034,0 \\
\hline Índice de trabalho $(\mathbf{W I )}$ & $\mathbf{k W h} / \mathbf{s t}$ & $\mathbf{1 5 , 4 1}$ \\
\hline
\end{tabular}

Foi possível notar uma diferença significativa nos valores obtidos para as duas escórias. Isto será discutido ainda neste capítulo.

\subsection{ENSAIOS COM LÍQUIDO DENSO}

Os ensaios com líquido denso foram realizados com béquer e centrífuga, de acordo com as massas e cada fração granulométrica mostradas na tabela 5.18. 
Tabela 5.18 - Ensaios de líquido denso.

\begin{tabular}{|c|c|c|}
\hline Fração $(\mathbf{m m})$ & Massa $\mathbf{( g )}$ & Técnica \\
\hline$+0,841$ & 130,7 & Béquer \\
\hline$+0,420$ & 145,2 & Béquer \\
\hline$+0,210$ & 73,7 & Béquer \\
\hline$+0,149$ & 84,3 & Centrífuga \\
\hline$+0,074$ & 98,9 & Centrífuga \\
\hline$-0,074$ & 87,0 & Centrífuga \\
\hline
\end{tabular}

O líquido denso utilizado foi o bromofórmio 98\% P.A. ( $\rho=2,81-2,84)$. Para os ensaios com béquer, foi utilizado um béquer de $500 \mathrm{ml}$ (figura 5.24). A centrífuga utilizada era do fabricante Nova Técnica, girando a $1200 \mathrm{rpm}$, pelo tempo de 5 minutos. O flutuado e o afundado (respectivamente os produtos leve e pesado) eram retirados e o bromofórmio era recuperado. Após secagem em estufa, o material foi pesado, identificado, embalado e enviado para análise.

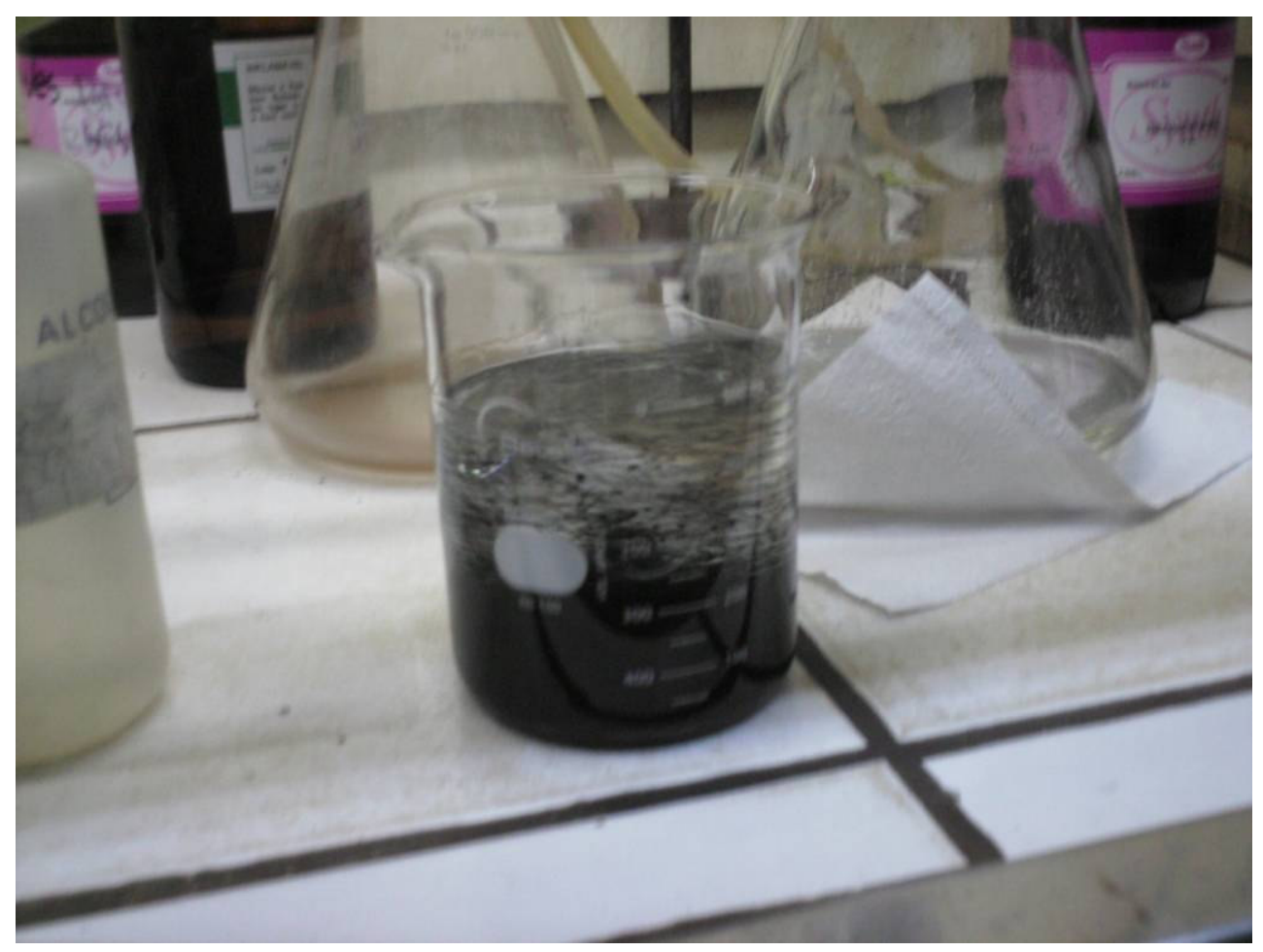

Figura 5.24 - Ensaio realizado no béquer.

Os produtos foram enviados para a Morro Azul, onde foi realizada separação magnética das frações e posterior análise química. Estes resultados são descritos 
a seguir neste mesmo capítulo. Os resultados obtidos diretamente dos testes de concentração são descritos na tabela 5.19 .

Tabela 5.19 - Distribuições de massas dos ensaios com líquido denso.

\begin{tabular}{|c|c|c|c|}
\hline Malha (mm) & Flutuado (g) & Afundado (g) & Total $\mathbf{( g )}$ \\
\hline 0,850 & 0,5 & 130,2 & 130,7 \\
\hline 0,425 & 0,5 & 144,6 & 145,1 \\
\hline 0,210 & 0,6 & 72,9 & 73,5 \\
\hline 0,150 & 1,5 & 82,8 & 84,3 \\
\hline 0,075 & 1,0 & 97,4 & 98,4 \\
\hline Fundo & 0,6 & 85,8 & 86,4 \\
\hline TOTAL & $\mathbf{4 , 7}$ & $\mathbf{6 1 3 , 7}$ & $\mathbf{6 1 8 , 4}$ \\
\hline
\end{tabular}

É notável a baixíssima recuperação mássica nos ensaios realizados no líquido denso. Devido às diferenças de tonalidade do afundado e do flutuado e às características intrínsecas da operação de refino, entende-se que o principal motivo de isto ter ocorrido é que o material flutuado continha apenas fundentes que não reagiram com o ferroníquel bruto. Isto foi confirmado pelas análises químicas.

\subsection{ENSAIOS EM MESA MOZLEY}

Os ensaios em mesa Mozley também foram realizados por fração granulométrica. Neste caso, a água de lavagem foi regulada de acordo com seu efeito no fluxo material, de forma que cada ensaio obtivesse um perfil similar da carga em seu interior. O perfil alvo é retratado na figura 5.25 . Os resultados são retratados na tabela 5.20 .

De maneira análoga, cada alíquota de concentrado e rejeito foi seca em estufa, pesada, identificada e embalada para transporte. Os materiais foram enviados à Morro do Níquel para realização de análises químicas por via úmida, de acordo com o procedimento indicado na figura 5.26. 


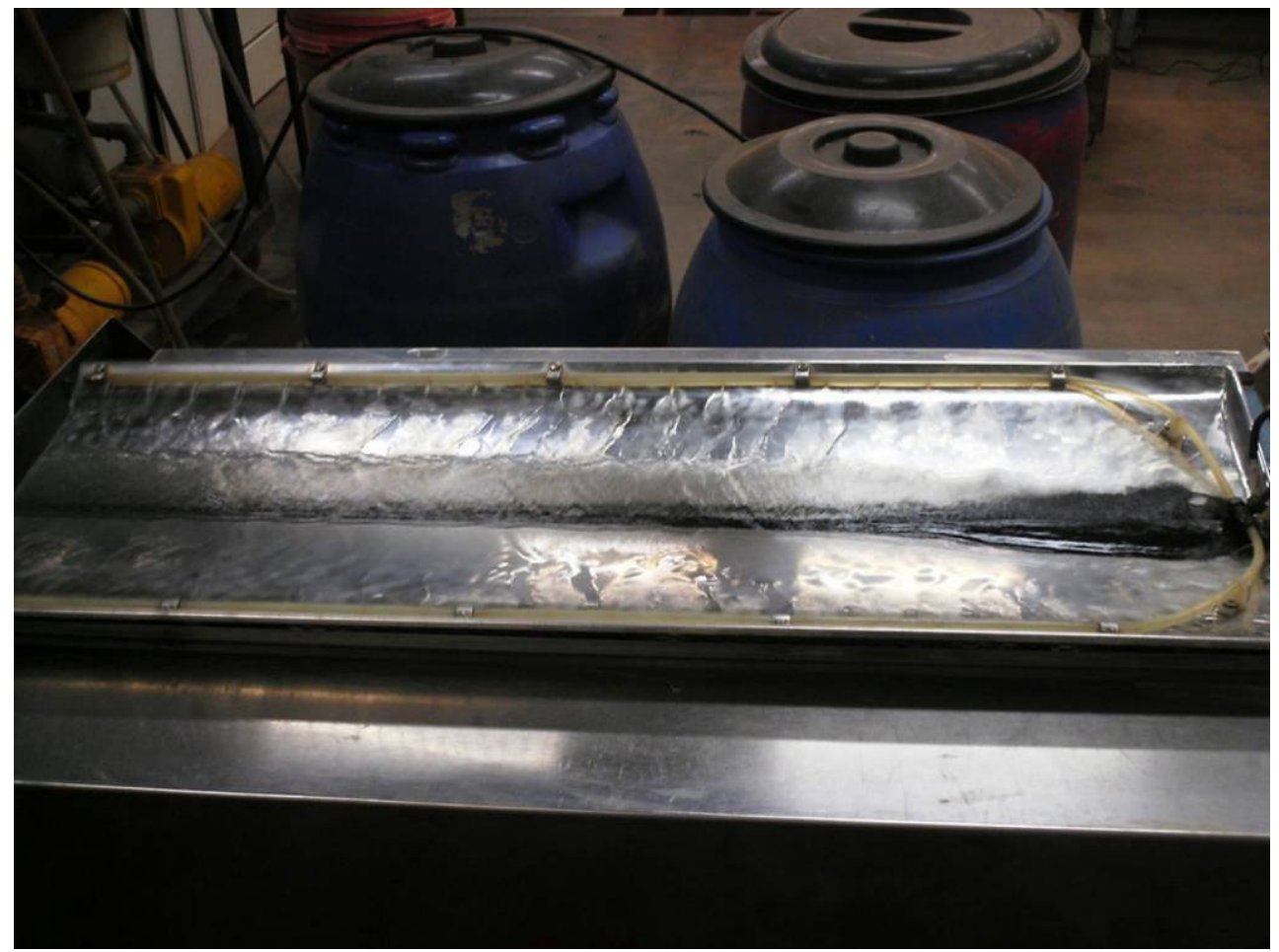

Figura 5.25 - Ensaio realizado na mesa Mozley.

Tabela 5.20 - Distribuições de massas dos ensaios com mesa Mozley.

\begin{tabular}{|c|c|c|}
\hline Malha (mm) & Concentrado & Rejeito \\
\hline 0,425 & 0,313 & 0,687 \\
\hline 0,210 & 0,240 & 0,760 \\
\hline 0,150 & 0,303 & 0,697 \\
\hline 0,075 & 0,079 & 0,921 \\
\hline Fundo & 0,062 & 0,938 \\
\hline GLOBAL & $\mathbf{0 , 1 9 9}$ & $\mathbf{0 , 8 0 1}$ \\
\hline
\end{tabular}

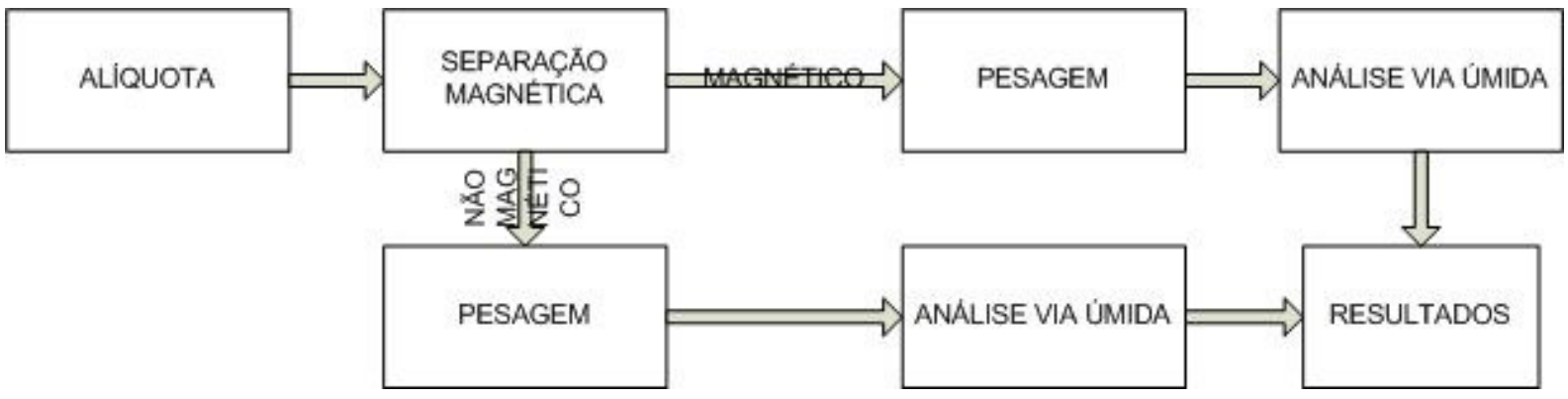

Figura 5.26 - Realização de análises químicas por via úmida.

Os resultados são discutidos mais adiante neste capítulo. 


\subsection{SEPARAÇÃO MAGNÉTICA E ANÁLISES QUÍMICAS}

O material recebido na Morro do Níquel foi separado magneticamente antes que fosse realizada análise química por via úmida. Os resultados para cada ensaio são descritos a seguir.

\subsubsection{LÍQUIDO DENSO}

As análises químicas de cada fração produziram os resultados mostrados nas tabelas 5.21 e 5.22. A coluna da extrema direita indica a fração mássica de cada fração, magnética e não magnética.

Tabela 5.21 - Análises químicas das frações flutuadas.

\begin{tabular}{|c|c|c|c|c|c|c|c|c|c|c|c|}
\hline $\begin{array}{c}\text { Malha } \\
(\mathbf{m m})\end{array}$ & Tipo & $\mathbf{N i}^{\mathbf{0}}$ & $\mathbf{N i O}$ & $\mathbf{F e}^{\mathbf{0}}$ & $\mathbf{F e O}$ & $\mathbf{S i O}_{2}$ & $\begin{array}{c}\mathbf{M g O}+ \\
\mathbf{C a O}\end{array}$ & $\mathbf{C}$ & $\mathbf{S}$ & $\mathbf{P}$ & $\begin{array}{c}\text { Fração } \\
\text { (massa) }\end{array}$ \\
\hline \multirow{2}{*}{0,850} & Mag. & 0,0 & 0,0 & 0,0 & 0,0 & 0,0 & 0,0 & 0,0 & 0,0 & 0,0 & 0,0 \\
\cline { 2 - 12 } & Não mag. & - & 0,39 & - & 16,8 & 35,2 & 27,2 & 0,902 & 0,082 & 0,09 & 100,0 \\
\hline \multirow{2}{*}{0,425} & Mag. & 0,0 & 0,0 & 0,0 & 0,0 & 0,0 & 0,0 & 0,0 & 0,0 & 0,0 & 0,0 \\
\cline { 2 - 12 } & Não mag. & - & 2,02 & - & 15,1 & 38,9 & 30,5 & 1,525 & 0,102 & 0,09 & 100,0 \\
\hline \multirow{2}{*}{0,212} & Mag. & 0,0 & 0,0 & 0,0 & 0,0 & 0,0 & 0,0 & 0,0 & 0,0 & 0,0 & 0,0 \\
\cline { 2 - 12 } & Não mag. & - & 1,56 & - & 9,7 & 42,4 & 25,0 & 2,971 & 0,111 & 0 & 100 \\
\hline \multirow{2}{*}{0,150} & Mag. & 0,0 & 0,0 & 0,0 & 0,0 & 0,0 & 0,0 & 0,0 & 0,0 & 0,0 & 0,0 \\
\cline { 2 - 12 } & Não mag. & - & 1,24 & - & 8,4 & 46,1 & 22,9 & 3,298 & 0,094 & 0,12 & 100,0 \\
\hline \multirow{2}{*}{0,075} & Mag. & 0,0 & 0,0 & 0,0 & 0,0 & 0,0 & 0,0 & 0,0 & 0,0 & 0,0 & 0,0 \\
\cline { 2 - 11 } & Não mag. & - & 1,13 & - & 7,5 & 42,5 & 22,9 & 3,486 & 0,102 & 0,05 & 100,0 \\
\hline \multirow{2}{*}{$-0,075$} & Mag. & 0,0 & 0,0 & 0,0 & 0,0 & 0,0 & 0,0 & 0,0 & 0,0 & 0,0 & 0,0 \\
\cline { 2 - 11 } & Não mag. & - & 0,35 & - & 12,1 & 29,3 & 26,1 & 5,401 & 0,127 & 0,18 & 100,0 \\
\hline
\end{tabular}


Tabela 5.22 - Análises químicas das frações afundadas.

\begin{tabular}{|c|c|c|c|c|c|c|c|c|c|c|c|}
\hline $\begin{array}{c}\text { Malha } \\
(\mathbf{m m})\end{array}$ & Tipo & $\mathbf{N i}^{\mathbf{0}}$ & $\mathbf{N i O}$ & $\mathbf{F e}^{\mathbf{0}}$ & $\mathbf{F e O}$ & $\mathbf{S i O}_{\mathbf{2}}$ & $\begin{array}{c}\mathbf{M g O}+ \\
\mathbf{C a O}\end{array}$ & $\mathbf{C}$ & $\mathbf{S}$ & $\mathbf{P}$ & $\% \mathbf{m a g}$. \\
\hline \multirow{2}{*}{0,850} & Mag. & 0,73 & - & 31,9 & - & 18,5 & 24,7 & 0,091 & 0,066 & 0,21 & 100 \\
\cline { 2 - 12 } & Não mag. & 0,0 & 0,0 & 0,0 & 0,0 & 0,0 & 0,0 & 0,0 & 0,0 & 0,0 & 0,0 \\
\hline \multirow{2}{*}{0,425} & Mag. & 0,90 & - & 36,0 & - & 14,8 & 23,4 & 0,097 & 0,066 & 0,11 & 100 \\
\cline { 2 - 12 } & Não mag. & 0,0 & 0,0 & 0,0 & 0,0 & 0,0 & 0,0 & 0,0 & 0,0 & 0,0 & 0,0 \\
\hline \multirow{2}{*}{0,212} & Mag. & 0,77 & - & 30,9 & - & 18,8 & 26,7 & 0,110 & 0,050 & 0,20 & 100,0 \\
\cline { 2 - 12 } & Não mag. & 0,0 & 0,0 & 0,0 & 0,0 & 0,0 & 0,0 & 0,0 & 0,0 & 0,0 & 0,0 \\
\hline \multirow{2}{*}{0,150} & Mag. & 2,69 & - & 29,6 & - & 27,8 & 25,4 & 0,115 & 0,06 & 0,19 & 96,0 \\
\cline { 2 - 12 } & Não mag. & - & 0,33 & - & 30,0 & 21,46 & 28,6 & 0,120 & 0,077 & 0,20 & 4,0 \\
\hline \multirow{2}{*}{0,075} & Mag. & 0,64 & - & 30,48 & - & 24,7 & 25,4 & 0,102 & 0,065 & 0,10 & 83,4 \\
\cline { 2 - 11 } & Não mag. & - & 0,40 & - & 34,4 & 21,1 & 28,0 & 0,106 & 0,068 & 0,09 & 16,6 \\
\hline \multirow{2}{*}{$-0,075$} & Mag. & 0,37 & - & 26,5 & - & 23,8 & 25,4 & 0,274 & 0,072 & 0,010 & 81,6 \\
\cline { 2 - 10 } & Não mag. & - & 0,24 & - & 29,4 & 27,3 & 27,3 & 0,276 & 0,071 & 0,071 & 18,4 \\
\hline \multicolumn{2}{|c|}{ GLOBAL } & $\mathbf{0 , 9 3}$ & $\mathbf{0 , 0 2}$ & $\mathbf{2 9 , 8 1}$ & $\mathbf{1 , 8 2}$ & $\mathbf{2 0 , 6 0}$ & $\mathbf{1 5 , 0 7}$ & $\mathbf{0 , 1 3}$ & $\mathbf{0 , 0 6}$ & $\mathbf{0 , 1 4}$ & - \\
\hline
\end{tabular}

\subsubsection{MESA MOZLEY}

As análises químicas de cada fração produziram os resultados mostrados nas tabelas 5.23 e 5.24 . A coluna da extrema direita indica a fração mássica de cada fração, magnética e não magnética.

Tabela 5.23 - Análises químicas do concentrado.

\begin{tabular}{|c|c|c|c|c|c|c|c|c|c|c|c|}
\hline $\begin{array}{c}\text { Malha } \\
(\mathbf{m m})\end{array}$ & Tipo & $\mathbf{N i}^{\mathbf{0}}$ & $\mathbf{N i O}$ & $\mathbf{F e}^{\mathbf{0}}$ & $\mathbf{F e O}$ & $\mathbf{S i O}_{2}$ & $\begin{array}{c}\mathbf{M g O}+ \\
\mathbf{C a O}\end{array}$ & $\mathbf{C}$ & $\mathbf{S}$ & $\mathbf{P}$ & $\% \mathbf{m a g}$. \\
\hline \multirow{2}{*}{0,425} & Mag. & 31,70 & 0,00 & 61,0 & 0 & 1,3 & 3,9 & 0,201 & 0,065 & 0,006 & 100,0 \\
\cline { 2 - 12 } & Não mag. & 0,0 & 0,0 & 0,0 & 0,0 & 0,0 & 0,0 & 0,0 & 0,0 & 0,0 & 0,0 \\
\hline \multirow{2}{*}{0,210} & Mag. & 2,63 & 0,00 & 40,2 & 0 & 9,0 & 27,6 & 0,081 & 0,051 & 0,26 & 97,6 \\
\cline { 2 - 12 } & Não mag. & 0,00 & 0,59 & 0 & 50,4 & 14,0 & 27,8 & 0,067 & 0,046 & 0,26 & 2,4 \\
\hline \multirow{2}{*}{0,106} & Mag. & 1,61 & 0,00 & 40,5 & 0 & 8,2 & 23,7 & 0,132 & 0,067 & 0,14 & 100,0 \\
\cline { 2 - 12 } & Não mag. & 0,0 & 0,0 & 0,0 & 0,0 & 0,0 & 0,0 & 0,0 & 0,0 & 0,0 & 0,0 \\
\hline \multirow{2}{*}{0,075} & Mag. & 2,63 & 0,00 & 43,1 & 0 & 8,5 & 20,8 & 0,225 & 0,066 & 0,24 & 86,0 \\
\cline { 2 - 11 } & Não mag. & 0,00 & 0,52 & 0 & 49,8 & 13,8 & 23,4 & 0,264 & 0,081 & 0,24 & 14,0 \\
\hline \multirow{2}{*}{$-0,075$} & Mag. & 1,27 & 0,00 & 35,4 & 0 & 15,0 & 22,8 & 0,503 & 0,068 & 0,23 & 100,0 \\
\cline { 2 - 11 } & Não mag. & 0,0 & 0,0 & 0,0 & 0,0 & 0,0 & 0,0 & 0,0 & 0,0 & 0,0 & 0,0 \\
\hline
\end{tabular}


Tabela 5.24 - Análises químicas do rejeito.

\begin{tabular}{|c|c|c|c|c|c|c|c|c|c|c|c|}
\hline $\begin{array}{c}\text { Malha } \\
(\mathbf{m m})\end{array}$ & Tipo & $\mathbf{N i}^{\mathbf{0}}$ & $\mathbf{N i O}$ & $\mathbf{F e}^{\mathbf{0}}$ & $\mathbf{F e O}$ & $\mathbf{S i O}_{\mathbf{2}}$ & $\begin{array}{c}\mathbf{M g O}+ \\
\mathbf{C a O}\end{array}$ & $\mathbf{C}$ & $\mathbf{S}$ & $\mathbf{P}$ & $\% \mathbf{m a g}$. \\
\hline \multirow{2}{*}{0,425} & Mag. & 24,1 & 0 & 56,0 & 0 & 4,62 & 9,8 & 0,246 & 0,072 & 0,005 & 100,0 \\
\cline { 2 - 12 } & Não mag. & 0,0 & 0,0 & 0,0 & 0,0 & 0,0 & 0,0 & 0,0 & 0,0 & 0,0 & 0,0 \\
\hline \multirow{2}{*}{0,210} & Mag. & 0,43 & 0 & 31,2 & 0 & 18,8 & 27,3 & 0,106 & 0,065 & 0,19 & 98,1 \\
\cline { 2 - 12 } & Não mag. & 0 & 0,22 & 0 & 25,2 & 29,5 & 31,9 & 0,038 & 0,059 & 0,13 & 1,9 \\
\hline \multirow{2}{*}{0,106} & Mag. & 0,34 & 0 & 30,0 & 0 & 22,0 & 27,3 & 0,145 & 0,059 & 0,17 & 68,7 \\
\cline { 2 - 12 } & Não mag. & 0 & 0,23 & 0 & 26,8 & 30,1 & 34,5 & 0,144 & 0,050 & 0,16 & 31,3 \\
\hline \multirow{2}{*}{0,075} & Mag. & 0,35 & 0 & 29,9 & 0 & 21,5 & 28,6 & 0,281 & 0,066 & 0,10 & 88,8 \\
\cline { 2 - 11 } & Não mag. & 0 & 0,22 & 0 & 24,6 & 31,1 & 35,8 & 0,172 & 0,061 & 0,17 & 11,2 \\
\hline \multirow{2}{*}{$-0,075$} & Mag. & 0,38 & 0 & 29,1 & 0 & 19,2 & 28,6 & 0,399 & 0,082 & 0,14 & 100,0 \\
\cline { 2 - 11 } & Não mag. & 0,0 & 0,0 & 0,0 & 0,0 & 0,0 & 0,0 & 0,0 & 0,0 & 0,0 & 0,0 \\
\hline
\end{tabular}

\subsection{DISCUSSÃO}

Com esses resultados em mãos, foram realizados os cálculos das recuperações mássicas globais e de cada elemento presente, para o afundado, o flutuado, o concentrado e o rejeito, conforme tabelas 5.25 a 5.28 .

Tabela 5.25 - Recuperações do flutuado (líquido denso).

\begin{tabular}{|c|c|c|c|c|c|c|c|c|c|c|c|c|}
\hline $\begin{array}{c}\text { Malha } \\
(\mathbf{m m})\end{array}$ & Global & $\mathbf{N i}^{\mathbf{0}}$ & $\mathbf{N i O}$ & $\mathbf{N i}_{\text {tot }}$ & $\mathbf{F e}^{\mathbf{0}}$ & $\mathbf{F e O}$ & $\mathbf{F e}_{\text {tot }}$ & $\mathbf{S i O}_{2}$ & $\begin{array}{c}\mathbf{C a O}+ \\
\mathbf{M g O}\end{array}$ & $\mathbf{C}$ & $\mathbf{S}$ & $\mathbf{P}$ \\
\hline 0,850 & 0,004 & 0,000 & 1,000 & 0,002 & 0,000 & 1,000 & 0,002 & 0,007 & 0,007 & 0,037 & 0,005 & 0,002 \\
\hline 0,425 & 0,003 & 0,000 & 1,000 & 0,006 & 0,000 & 1,000 & 0,001 & 0,009 & 0,007 & 0,052 & 0,005 & 0,003 \\
\hline 0,210 & 0,008 & 0,000 & 1,000 & 0,013 & 0,000 & 1,000 & 0,002 & 0,018 & 0,012 & 0,182 & 0,018 & 0,005 \\
\hline 0,150 & 0,018 & 0,000 & 0,630 & 0,007 & 0,000 & 0,113 & 0,004 & 0,029 & 0,026 & 0,342 & 0,027 & 0,011 \\
\hline 0,075 & 0,010 & 0,000 & 0,150 & 0,015 & 0,000 & 0,013 & 0,002 & 0,018 & 0,015 & 0,256 & 0,016 & 0,005 \\
\hline Fundo & 0,007 & 0,000 & 0,053 & 0,006 & 0,000 & 0,015 & 0,003 & 0,008 & 0,012 & 0,121 & 0,012 & 0,056 \\
\hline TOTAL & $\mathbf{0 , 0 0 8}$ & $\mathbf{0 , 0 0 0}$ & $\mathbf{0 , 3 2 0}$ & $\mathbf{0 , 0 0 7}$ & $\mathbf{0 , 0 0 0}$ & $\mathbf{0 , 0 4 2}$ & $\mathbf{0 , 0 0 2}$ & $\mathbf{0 , 0 1 5}$ & $\mathbf{0 , 0 1 2}$ & $\mathbf{0 , 1 6 0}$ & $\mathbf{0 , 0 1 2}$ & $\mathbf{0 , 0 0 6}$ \\
\hline
\end{tabular}


Tabela 5.26 - Recuperações do afundado (líquido denso).

\begin{tabular}{|c|c|c|c|c|c|c|c|c|c|c|c|c|}
\hline $\begin{array}{c}\text { Malha } \\
(\mathbf{m m})\end{array}$ & Global & $\mathbf{N i}^{\mathbf{0}}$ & $\mathbf{N i O}$ & $\mathbf{N i}_{\text {tot }}$ & $\mathbf{F e}^{\mathbf{0}}$ & $\mathbf{F e O}$ & $\mathbf{F e}_{\text {tot }}$ & $\mathbf{S i O}_{\mathbf{2}}$ & $\begin{array}{c}\mathbf{C a O}+ \\
\mathbf{M g O}\end{array}$ & $\mathbf{C}$ & $\mathbf{S}$ & $\mathbf{P}$ \\
\hline 0,850 & 0,996 & 1,000 & 0,000 & 0,998 & 1,000 & 0,000 & 0,998 & 0,993 & 0,993 & 0,963 & 0,995 & 0,998 \\
\hline 0,425 & 0,997 & 1,000 & 0,000 & 0,994 & 1,000 & 0,000 & 0,999 & 0,991 & 0,993 & 0,948 & 0,995 & 0,997 \\
\hline 0,210 & 0,992 & 1,000 & 0,000 & 0,987 & 1,000 & 0,000 & 0,998 & 0,982 & 0,988 & 0,818 & 0,982 & 0,995 \\
\hline 0,150 & 0,982 & 1,000 & 0,370 & 0,993 & 1,000 & 0,888 & 0,996 & 0,971 & 0,974 & 0,659 & 0,973 & 0,989 \\
\hline 0,075 & 0,990 & 1,000 & 0,851 & 0,985 & 1,000 & 0,987 & 0,998 & 0,982 & 0,985 & 0,742 & 0,984 & 0,995 \\
\hline Fundo & 0,993 & 1,000 & 0,948 & 0,994 & 1,000 & 0,985 & 0,998 & 0,992 & 0,989 & 0,879 & 0,988 & 0,944 \\
\hline TOTAL & $\mathbf{0 , 9 9 2}$ & $\mathbf{1 , 0 0 0}$ & $\mathbf{0 , 6 8 0}$ & $\mathbf{0 , 9 9 3}$ & $\mathbf{1 , 0 0 0}$ & $\mathbf{0 , 9 5 8}$ & $\mathbf{0 , 9 9 8}$ & $\mathbf{0 , 9 8 5}$ & $\mathbf{0 , 9 8 8}$ & $\mathbf{0 , 8 4 0}$ & $\mathbf{0 , 9 8 8}$ & $\mathbf{0 , 9 9 4}$ \\
\hline
\end{tabular}

Tabela 5.27 - Recuperações do concentrado (mesa Mozley).

\begin{tabular}{|c|c|c|c|c|c|c|c|c|c|c|c|c|}
\hline $\begin{array}{c}\text { Malha } \\
(\mathbf{m m})\end{array}$ & Global & $\mathbf{N i}^{\mathbf{0}}$ & $\mathbf{N i O}$ & $\mathbf{N i}_{\text {tot }}$ & $\mathbf{F e}^{\mathbf{0}}$ & $\mathbf{F e O}$ & $\mathbf{F e}_{\text {tot }}$ & $\mathbf{S i O}_{2}$ & $\begin{array}{c}\mathbf{C a O}+ \\
\mathbf{M g O}\end{array}$ & $\mathbf{C}$ & $\mathbf{S}$ & $\mathbf{P}$ \\
\hline 0,425 & 0,313 & 0,375 & 0,000 & 0,375 & 0,332 & 0,000 & 0,332 & 0,114 & 0,154 & 0,272 & 0,292 & 0,354 \\
\hline 0,210 & 0,240 & 0,658 & 0,517 & 0,657 & 0,288 & 0,444 & 0,290 & 0,132 & 0,241 & 0,196 & 0,198 & 0,303 \\
\hline 0,106 & 0,303 & 0,749 & 0,000 & 0,707 & 0,460 & 0,000 & 0,393 & 0,127 & 0,258 & 0,284 & 0,341 & 0,267 \\
\hline 0,075 & 0,079 & 0,384 & 0,200 & 0,375 & 0,107 & 0,178 & 0,112 & 0,034 & 0,058 & 0,068 & 0,082 & 0,160 \\
\hline Fundo & 0,062 & 0,182 & 0,000 & 0,182 & 0,075 & 0,000 & 0,075 & 0,049 & 0,050 & 0,077 & 0,052 & 0,098 \\
\hline TOTAL & $\mathbf{0 , 1 9 9}$ & $\mathbf{0 , 5 1 8}$ & $\mathbf{0 , 1 5 3}$ & $\mathbf{0 , 5 1 3}$ & $\mathbf{0 , 2 5 9}$ & $\mathbf{0 , 1 2 4}$ & $\mathbf{0 , 2 5 2}$ & $\mathbf{0 , 0 9 8}$ & $\mathbf{0 , 1 8 2}$ & $\mathbf{0 , 1 3 9}$ & $\mathbf{0 , 1 7 7}$ & $\mathbf{0 , 2 5 4}$ \\
\hline
\end{tabular}

Tabela 5.28 - Recuperações do rejeito (mesa Mozley).

\begin{tabular}{|c|c|c|c|c|c|c|c|c|c|c|c|c|}
\hline $\begin{array}{c}\text { Malha } \\
(\mathbf{m m})\end{array}$ & Global & $\mathbf{N i}^{\mathbf{0}}$ & $\mathbf{N i O}$ & $\mathbf{N i}_{\text {tot }}$ & $\mathbf{F e}^{\mathbf{0}}$ & $\mathbf{F e O}$ & $\mathbf{F e}_{\text {tot }}$ & $\mathbf{S i O}_{2}$ & $\begin{array}{c}\mathbf{C a O}+ \\
\mathbf{M g O}\end{array}$ & $\mathbf{C}$ & $\mathbf{S}$ & $\mathbf{P}$ \\
\hline 0,425 & 0,687 & 0,625 & 0,000 & 0,625 & 0,668 & 0,000 & 0,668 & 0,886 & 0,846 & 0,728 & 0,708 & 0,646 \\
\hline 0,210 & 0,760 & 0,343 & 0,483 & 0,343 & 0,712 & 0,556 & 0,710 & 0,867 & 0,759 & 0,805 & 0,802 & 0,697 \\
\hline 0,106 & 0,697 & 0,251 & 1,000 & 0,293 & 0,540 & 1,000 & 0,607 & 0,873 & 0,742 & 0,716 & 0,659 & 0,733 \\
\hline 0,075 & 0,921 & 0,617 & 0,800 & 0,625 & 0,893 & 0,822 & 0,888 & 0,966 & 0,942 & 0,932 & 0,918 & 0,840 \\
\hline Fundo & 0,938 & 0,818 & 0,000 & 0,818 & 0,925 & 0,000 & 0,925 & 0,951 & 0,950 & 0,923 & 0,948 & 0,902 \\
\hline TOTAL & $\mathbf{0 , 8 0 1}$ & $\mathbf{0 , 4 8 2}$ & $\mathbf{0 , 8 4 7}$ & $\mathbf{0 , 4 8 7}$ & $\mathbf{0 , 7 4 1}$ & $\mathbf{0 , 8 7 6}$ & $\mathbf{0 , 7 4 8}$ & $\mathbf{0 , 9 0 2}$ & $\mathbf{0 , 8 1 8}$ & $\mathbf{0 , 8 6 1}$ & $\mathbf{0 , 8 2 3}$ & $\mathbf{0 , 7 4 6}$ \\
\hline
\end{tabular}

Notou-se uma baixíssima recuperação mássica dos elementos $\mathrm{Fe}$ e Ni. Já nos ensaios com mesa Mozley, os resultados foram bem diferentes. Cabe ressaltar que, já durante os ensaios, foi possível observar uma diferença de coloração no concentrado. 
Como os resultados dos ensaios com líquido denso mostraram baixa recuperação, foram calculados os enriquecimentos por faixa granulométrica apenas para os ensaios com a mesa, indicados na tabela 5.29.

Tabela 5.29 - Enriquecimentos (mesa Mozley).

\begin{tabular}{|c|c|c|c|c|c|c|c|}
\hline Malha (mm) & $\mathbf{N i}^{\mathbf{0}}$ & $\mathbf{F e}^{\mathbf{0}}$ & $\mathbf{S i O}_{\mathbf{2}}$ & $\mathbf{C a O}+\mathbf{M g O}$ & $\mathbf{C}$ & $\mathbf{S}$ & $\mathbf{P}$ \\
\hline 0,425 & 19,79 & 0,57 & 0,01 & 0,02 & 0,06 & 0,27 & 0,01 \\
\hline 0,210 & 2,81 & 0,32 & 0,08 & 0,28 & 0,02 & 0,14 & 0,31 \\
\hline 0,106 & 2,01 & 0,52 & 0,07 & 0,25 & 0,04 & 0,32 & 0,15 \\
\hline 0,075 & 1,44 & 0,11 & 0,02 & 0,05 & 0,02 & 0,08 & 0,15 \\
\hline Fundo & 0,38 & 0,07 & 0,05 & 0,05 & 0,04 & 0,05 & 0,09 \\
\hline GLOBAL & $\mathbf{2 , 5 3}$ & $\mathbf{0 , 2 9}$ & $\mathbf{0 , 0 6}$ & $\mathbf{0 , 1 9}$ & $\mathbf{0 , 0 2}$ & $\mathbf{0 , 1 4}$ & $\mathbf{0 , 2 2}$ \\
\hline
\end{tabular}

Apesar de ter havido enriquecimento baixo, os elementos complicadores do processo praticamente não foram arrastados junto ao metal concentrado. $O$ ferro foi enriquecido em pequena quantidade também. Globalmente, foi recuperado mais da metade de todo o níquel contido para o concentrado, demonstrando que a concentração gravítica viabiliza a recuperação do metal.

Continuando nos aspectos de processo, os índices de trabalho obtidos para as duas escórias (24,61 para a resfriada e 15,14 para a granulada) mostram que há uma vantagem de se granular a escória: o consumo energético da moagem seria quase $40 \%$ menor ao processá-la desta forma. Esta é uma recomendação para os operadores do refino: deve-se minimizar o resfriamento da escória ao tempo, de forma a melhorar a operação como um todo.

Um dos problemas observados no circuito é a freqüente parada da instalação, devido ao desgaste prematuro das barras de impacto do britador secundário. Este ponto também, em princípio, poderia ser melhorado ao se granular a escória. Outra medida que poderia ser tomada é a colocação de um extrator de sucata com magneto de baixa intensidade, a montante do equipamento, de forma a minimizar o ingresso de materiais não britáveis no processo. 
Imagina-se então que o circuito deverá operar da seguinte maneira:

- a escória é recuperada com uma pá-carregadeira e descarregada sobre uma moega com grelha. O material retido é inspecionado pelo operador. As carepas metálicas são retornadas ao forno elétrico, enquanto que o material leve é fragmentado com marreta e depois retornado à grelha;

- o material passante segue para um britador primário de mandíbulas;

- o material britado passa por um transportador de correia, onde está localizado um extrator de sucata. O metal recuperado é levado diretamente à estação de refino. O restante é então britado em britador secundário, também de mandíbulas;

- o material britado passa novamente por um transportador de correia, onde também está localizado outro extrator de sucata. O metal recuperado é levado à estação de refino ou ao forno elétrico. $O$ material segue então para o moinho de barras;

- no moinho, é realizada adição de água e o material moído é descarregado em um jigue primário. O leve do jigue primário segue para o jigue secundário, enquanto que o pesado é descarregado em uma piscina de decantação, para que haja recuperação da água e o material possa ser manuseado. Uma vez desaguado, ele é secado e retorna ao processo (forno elétrico);

- o pesado do jigue secundário retorna ao jigue primário. O leve constitui a escória final e é descartado em outra piscina de decantação, de forma que o material possa ser manuseado e a água, reaproveitada. 


\section{CONSIDERAÇÕES FINAIS}

Estes resultados indicam que é possível concentrar os metais contidos na escória do refino por métodos gravíticos. Foi comprovado, então, o que é verificado na prática: as usinas de processamento de escória de ferro-ligas, de uma maneira geral, buscam o reaproveitamento do metal perdido nesta corrente de processo, e normalmente o fazem por rotas físicas.

Entretanto, apesar de a operação ser bem conduzida, principalmente devido à competência da equipe técnica, é possível tornar o processo menos susceptível às variações intrínsecas da escória.

Entende-se que a melhor opção é a via úmida. A instalação fica simplificada ao ponto de permitir sua inclusão no plano de investimento de novos projetos. Até pouco tempo, o que se observava era, ainda na fase de projeto básico, a postergação da implantação da área de processamento de escória para um momento posterior ao escalonamento de produção. Isto ocorria devido à complexidade e ao custo de uma operação a seco, que era a rota normalmente escolhida por estudos de viabilidade.

Foi possível entender também como as escórias resfriada e granulada se comportam no circuito de cominuição, ao descobrir seus índices de trabalho. Esta descoberta resulta numa recomendação aos operadores da área de refino, que devem minimizar a formação de escória resfriada, para diminuir o consumo de energia na moagem.

Finalmente, consegue-se justificar estas diferenças do comportamento à cominuição pelo entendimento da diferença textural das duas escórias. 
As modificações sugeridas são:

- substituição do britador secundário de impacto por um de mandíbulas;

- instalação de dois ímãs estáticos de baixa intensidade antes da alimentação de cada britador, de forma a diminuir a necessidade de parada da instalação por obstrução e/ou desgaste excessivo; e

- a granulação de todas as escórias do refino, para economizar energia no processo de cominuição.

Como sugestão para trabalhos futuros, poderia ser verificada a diferença de comportamentos no circuito de concentração entre as duas escórias, o que poderia determinar se existe alguma melhora na recuperação com a escória resfriada. 


\section{REFERÊNCIAS BIBLIOGRÁFICAS}

AGRICOLA, G. B. De Re Metallica. Basiléia, Suíça, 1556.

ALI, S. H. Mining, the Environment, and Indigenous Development Conflicts. $1^{\text {st }}$ ed. 245 p. Tucson, EUA, University of Arizona Press, 2003.

ALMEIDA, A. M. M.; SILVEIRA, R. C. Manual de Operação - Fornos Elétricos de Redução. Relatório técnico. 122 p. Belo Horizonte, RCS Consultoria e Participações, 1990.

BNDES. Níquel - Novos Parâmetros de Desenvolvimento. BNDES, Brasília, 2000. Arquivo recuperado da internet em 06/05/2007 no endereço $<$ http://www.bndes.gov.br/conhecimento/relato/niquel.pdf>.

BENNETT, C. O.; MYERS, J. E. Fundamentals of Momentum, Heat and Mass Transfer. $3^{\text {rd }}$ ed. 848 p. New York, John Wiley and Sons, 1984.

BOND, F. C. Crushing and Grinding Calculations. In: British Chemical Engineering. British Chemical Engineering, vol. 6. pp. 378-385, London, 1961.

BURT, R. O. Gravity Concentration Technology. New York, Elsevier, 1984.

BUTTS, A. Metallurgical Problems. $1^{\text {st }}$ ed. 446 p. New York, McGraw-Hill, 1943.

CAMPOS, A. R.; DA LUZ, A. B.; CARVALHO, E. A. Capítulo 7 - Separação em Meio Denso. In: DA LUZ et al. Tratamento de Minérios. $4^{\mathrm{a}}$ ed. 867 p. Rio de Janeiro, CETEM, 2004. 
CHAVES, A. P. et al. Teoria e Prática do Tratamento de Minérios - Volume 1. 2ª ed. 267 p. São Paulo, Signus, 2002.

CHAVES, A. P.; PERES, A. E. C. Teoria e Prática do Tratamento de Minérios Volume 3. 3aa ed. 248 p. São Paulo, Signus, 2006.

CHAVES, A. P. Beneficiamento densitário. Apostila, s.n.e.

CRANFIELD, P. The Nickel Industry - Long-term drivers of nickel supply \& demand. In: International Nickel Study Group Annual Conference. INSG, Lisboa, Portugal, 2006.

DALVI, A.D.; BACON, W. G.; OSBORNE, R.C. The Past and the Future of Nickel Laterites. In: PDAC International Convention, Trade Show \& Investors Exchange. Mississauga, Canadá, 7-10 março, 2004.

DEGEL, R. Process know-how, furnace dimensioning and start-up assistance. In: Symposium on 100 Years SAF by SMS Demag. Araxá, Brasil, 16 de setembro de 2006.

DOR, A. A.; SKRETTING, H. The production of ferronickel by the Rotary KilnElectric Furnace process. In: International Laterite Symposium. SME, New York, 1979.

EC. The Way Back: Sudbury Lakes Recovering from Acid Rain. In: The Science and the Environment Bulletin. Environment Canada, Montréal, Canadá, jul-ago., 2001. Disponível em: < http://www.ec.gc.ca/science/sandejuly01/article2_e.html>. Acesso em: 20 mai., 2098. 
FERNANDES, N. H. et al. Grau metamórfico das formações ferríferas do greenstone belt Morro do Ferro: abordagem utilizando texturas de exsolução em anfibólios. In: Geociências, vol. 22, oㅜ 1, pp. 53-63. São Paulo, Unesp, 1960.

FIGUEIRA, H. V. O.; ALMEIDA, S. L. M.; DA LUZ, A.B. Capítulo 4 - Cominuição. In: DA LUZ et al. Tratamento de Minérios. $4^{a}$ ed. 867 p. Rio de Janeiro, CETEM, 2004.

FRANK, M. Cuba mulls reduction in nickel output. Reuters, Havana, Cuba, 3 de março de 2009. Disponível em: <http://www.reuters.com/article/ companyNewsAndPR/idUSN0345695620090303>. Acesso em: 05 mar., 2009.

GAUDIN, A. M. Principles of Minerals Dressing. New York, Mc Graw-Hill, 1945.

GIANNONE, J. A. Hedge fund head says times right for global macro. Reuters, Nova York, EUA, 26 de fevereiro de 2009. Disponível em: $<$ http://www.reuters.com/article/americasDealsNews/idUSTRE51P7NV20090226? $\mathrm{sp}=$ true $>$. Acesso em: 05 mar., 2009.

HEYDENRYCH, M. D. Modelling of rotary kilns. Tese (Doutorado) - Universiteit Twente. 105 p. Enschede, Holanda, 2001.

KELLY, E. G.; SPOTTISWOOD, D. J. Introduction to Mineral Processing. $1^{\text {st }}$ ed. 491 p. New York, John Wiley \& Sons, 1982.

$\mathrm{KOSICH}$, D. \$20/lb nickel prices unsustainable, sharp price correction coming S\&P. Mineweb - Base Metals. Johanesburgo, África do Sul, 09 mai., 2007. Disponível em: <http://www.mineweb.co.za/mineweb/view/mineweb/en/page36? oid=20648\&sn=Detail>. Acesso em: 26 jun., 2008. 
KUCK, P. H. Nickel. U. S. Geological Survey - Mineral Commodity Summaries. USGS, Reston, EUA, jan. 2006. Disponível em: <http://minerals.usgs.gov/minerals/pubs/commodity/nickel/nickemcs06.pdf>. Acesso em: 20 mai., 2009.

LAWVER, J. E.; HOPSTOCK, D. M. Wet magnetic separation of fine weakly magnetic minerals. Minerals Science Engineering. Vol. 6, no 3, p.154-172, Jul. 1974.

LEVIN, J. Observations on the Bond standard grindability test, and a proposal for a standard grindability test for fine materials. In: Journal of the South African Institute of Mining and Metallurgy, vol. 89, no 1, pp. 13-21. Johannesburg, SAIMM, 1989.

LINS, F. A. F. Capítulo 5 - Concentração Gravítica. In: DA LUZ et al. Tratamento de Minérios. $4^{\mathrm{a}}$ ed. 867 p. Rio de Janeiro, CETEM, 2004.

MANO, E. S. Caracterização Tecnológica de Produtos de Beneficiamento de Minério de Ni-Cu-Co de Fortaleza de Minas, MG. Dissertação (Mestrado) Escola Politécnica da Universidade de São Paulo. 91 p. São Paulo, 2002.

METSO. Manual de Britagem. $6^{\underline{a}}$ ed. 501 p. Metso Minerals, Sorocaba, 2005.

MILLS, C. Process design, scale-up, and plant design for gravity concentration. In: MULAR, A.L.; BHAPPU, R.B. Mineral Processing Plant Design. New York, SME/AIME, 1978.

MOURÃO, M. B. (org.). Introdução à Siderurgia. $1^{\underline{a}}$ ed. 428 p. São Paulo, ABM, 2007. 
NAPIER-MUNN, T. J. et al. Mineral comminution circuits - Their operation and optimization. $3^{\text {rd }}$ ed. 413 p. Indooroopilly, Austrália, JKMRC, 2005.

NORISLK NICKEL. History. Toronto, Canadá, 2008. Disponível em: < http://www.nornik.ru/en/about/history/>. Acesso em: 13 ago., 2009.

NORTON, K. Nickel - Major market developments in January. Reuters, Londres, Inglaterra, 11 de fevereiro de 2009. Disponível em: <http://www.reuters.com/ article/etfNews/idUSLB12870520090211?sp=true>. Acesso em: 05 mar., 2009.

PARKER, J. A. L.; LOVEDAY, G. K. Recovery of metal from slag in the ferro-alloy industry. In: Hidden Wealth. Johannesburg, South African Institute of Mining and Metallurgy, 1996.

PENNSYLVANIA CRUSHER. Handbook of Crushing. $1^{\text {a }}$ ed. 43 p. Pennsylvania Crusher Company, Broomall, EUA, 2006.

ROGOFF, K. The Silver Lining in High Commodity Prices. Environmental News Network. Fairfield, IA, EUA, 19 mai, 2008. Disponível em: <http://www.enn.com/business/article/36503>. Acesso em: 26 jun., 2008.

ROSEMBERG, S. J. Nickel and Its Alloys. $1^{\text {st }}$ ed. 156 p. National Bureau of Standards Monograph nำ106, National Bureau of Standards, Washington, 1968.

ROSENQVIST, T. Principles of Extractive Metallurgy. $2^{\text {nd }}$ ed. 506 p. Trondheim, Tapir Forlag, 2004.

SAMPAIO, J. A.; DA LUZ, A. B. Capítulo 8 - Separação Magnética e Eletrostática. In: DA LUZ et al. Tratamento de Minérios. 4a ed. 867 p. Rio de Janeiro, CETEM, 2004. 
SAMPAIO, C. H.; TAVARES, L. M. M. Beneficiamento gravimétrico - uma introdução aos processos de concentração mineral e reciclagem de materiais por densidade. $1^{\underline{a}}$ ed. 603 p. Porto Alegre, Editora da UFRGS, 2005.

SERWAY, R. A. Physics for Scientists and Engineers - Volume 3. $6^{\text {th }}$ ed. 928 p. Fort Worth, Thomson, 2004.

SILVEIRA, R. C. da. Fabricação de aços em fornos elétricos. $1^{a}$ ed. 264 p. Ouro Preto, Editora UFOP, 1997.

SOUZA SANTOS, T. D. Obtenção de ferro-níquel de garnierita por redução prévia a fusão. In: Boletim da Associação Brasileira de Metais, no 58, vol. 16. São Paulo, ABM, 1960.

TAGGART, A. et al. Handbook of Mineral Dressing. New York, John Wiley and Sons, 1945.

TERRY, B.; MONHEMIUS, A.J.; BURKIN, A.R. General introduction. In: BURKIN, A.R. Critical Reports on Applied Chemistry - Extractive Metallurgy of Nickel. $1^{\text {st }}$ ed. Vol. 17. 150 p. New York, John Wiley and Sons, 1987.

VOLK, K. E. Nickel und Nickellegierungen - Eigenschaften und Verhalten. $1^{\text {st }}$ ed. 440 p. Berlin, Spring Verlag, 1970.

WEISS, N. L. Mineral Processing Handbook. $1^{\text {st }}$ ed. Dearborn, USA, SME, 1985.

WILLS, B. A. Mineral Processing Technology. $4^{\text {th }}$ ed. 525 p. New York, Pergamon Press, 1988. 